\title{
A NATURALIST IN THE BAHAMAS
}

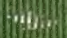

\author{
JOHN I. NORTHROP \\ OCTOBER 12, 1861 - JUNE 25, 1891
}

४

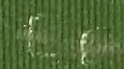

A MEMORIAL VOLUME 


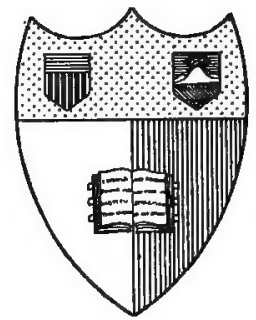

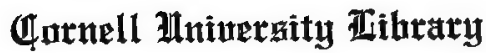

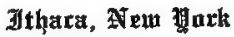

FROM

H.F osborm (editor)

RETURN TO

\section{ALBERT R. MANN LIBRARY}

ITHACA, N. Y. 


\section{Cornell University Library}

The original of this book is in the Cornell University Library.

There are no known copyright restrictions in the United States on the use of the text. 

LIFE AND WRITINGS OF JOHN I. NORTHROP 




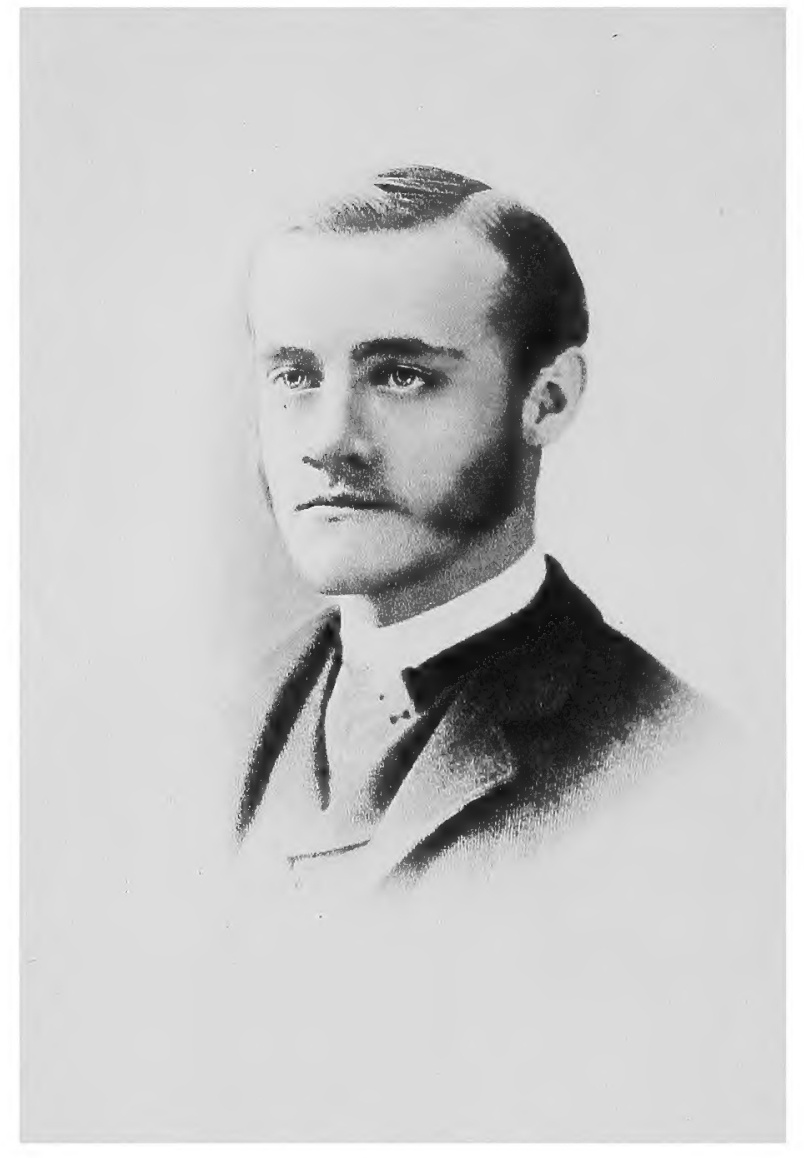

$$
\text { Sohed Rovthop. }
$$






\title{
A NATURALIST IN THE BAHAMAS
}

\author{
JOHN I. NORTHROP \\ OCtober I2, I86I-JUNe 25, I89I
}

\section{A SIDemorial Volume}

EDITED WITH.A BIOGRAPHICAL INTRODUCTION

BY

HENRY FAIRFIELD OSBORN

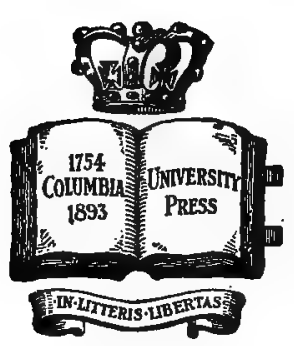

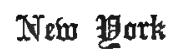

THE COLUMBIA UNIVERSITY PRESS

I9ro 


\section{$A 49227$ \\ CopVRight, igio,}

By THE COLUmbia UNIVERSTTY PRESS.

Published June, IgIo. 
IN ADDITION TO THE PAPERS BY DOCTOR NORTHROP, THE VOLUME CONTAINS AN ACCOUNT OF THE FLORA AND NARRATIVE OF THE BAHAMA TRIP BY MRS. NORTHROP; A REPORT ON THE CRUSTACEANS OF THE COLLECTION, CONTRIBUTED BY PROFESSOR WILLIAM H. RANKIN OF PRINCETON UNIVERSITY; A REPORT ON THE ACTINIA, CONTRIBUTED BY PROFESSOR J. PLAYFAIR MCMURRICH OF THE UNIVERSITY OF TORONTO, FORMERLY OF CLARK UNIVERSITY; A LIST OF THE GHELLS, AS DETERMINED BY PROFESSOR WILLIAM H. DALL OF THI JNITED STATES NATIONAL MUSEUM; AND A DESCRIPTION OF ICTERUS NORTHROPI BY PROFESSOR J. A. ALLEN OF THE AMERICAN MUSEUM OF NATURAL HISTORY. OF THE BOTANICAL COLLECTIONS, THE MARINE ALGE WERE DETERMINED BY MR. FRANK S. COLLINS OF MALDEN, MASSACHUSETTS, WHILE THE ACCOUNT OF THE TALMS WAS CONTRIBUTED BY DR. O. F. COOK OF THE DEPARTMENT OF AGRICULTURE AND THE UNITED STATES NATIONAL MUSEUM.

OTHER ASSISTANCE AND COÖPERATION IS DULY NOTED IN THE SEPARATE PAPERS THROUGHOUT THE BOOK. 



\section{TABLE OF CONTENTS}

PAGE

INTRODUCTION . . . . . . . . . . . . . . . .

Henry Fairfield Osborn.

Bahaman Trip, General Notes . . . . . . . . . I

Alice R. NORTHROP.

Notes on the Geology of the Bahamas . . . . . . 27

JOHN I. NORTHROP.

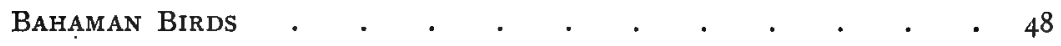

JOHN I. NORTHROP.

The Birds of Andros Island, Bahamas . . . . . . 50

JOHN I. NORTHROP.

Description of a New Species of ICTERUS From ANDros IsLAND,

Bahamas . . . . . . . . . . . . . 66

J. A. Allen.

The Northrop Collection of Crustacea from the Bahamas - 69

W. M. RANKIN.

List of Shells collected by DR. John I. Northrop in the Bahamas

IDentified by Professor William Healey Dall.

Notes on Some Actinians from the Bahama Islands Collected by the Late Dr. J. I. Northrop. With Appendix of DATE OF 1908 . . . . . . . . . . . . 103

J. Playfair McMurrich.

Flora of New Providence and Andros (Bahama Islands) • - 19 ALICE R. NORTHROP.

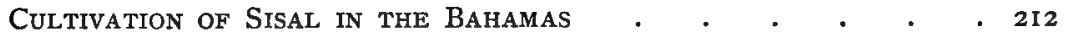

JOHN I. NORTHROP.

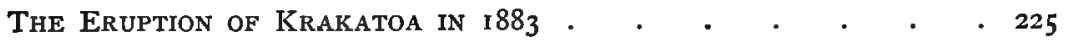

JOHN I. NORTHROP. 
PAGE

Plant Notes from Temiscouata County, Canada • • . . 240 JOHN I. NORTHROP.

Plant Notes from Tadousac and Temiscouata County, Canada . 250 John I. AND Alice R. NORthrop.

Notes on the Distribution of the Plants of Mount WashingTON, N.H. • • • • • • • . • • • • 255

JOHN I. AND ALICE R. NORTHROP.

A Study of the Histology of the Stem of the Wax Plant, HoYa CaRnosa (L.) R. BR. . . . . . . . 259 JOHN I. NORTHROP. 


\section{LIST OF ILLUSTRATIONS}

Portrait of Dr. John I. Northrop

Frontispiece

Ryswick

Facing $\quad 3$

The Bay at Nicol's Town . . . . . . . . . . . . 6

House at Nicol's Town . . . . . . . . . . . . . . 8

At Conch Sound . . . . . . . . . . . . . . 4 14

Fresh Creek . . . . . . . . . . . . . " 19

Cabbage Creek - . . . . . . . . . . . . 4 20

Coming to Anchor off the Dames Place . . . . . " " 22

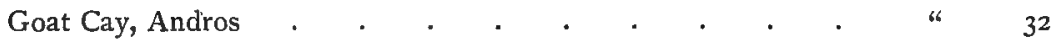

Ocean Hole, Nicol's Town • • • . . • • • • “ 34

Spruce Cay, New Providence, showing Erosion . . . " " 40

Icterus northropi Allen . . . . . . . . . " . 66

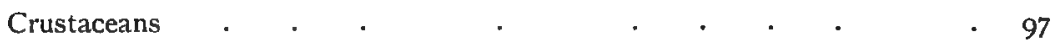

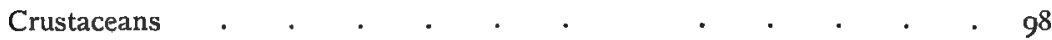

Actinians from the Bahama Islands . . . . . Facing 116

Map of New Providence and Andros . . . . . . . . II8

Main Street in Nicol's Town . . . . . . . . 4 " 122

In the High Coppet near Deep Creek . . . . . . " " 124

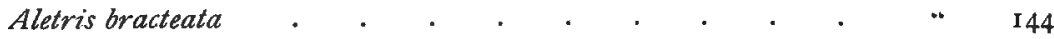

Hymenocallis arenicola . . . . . . . . . . 146

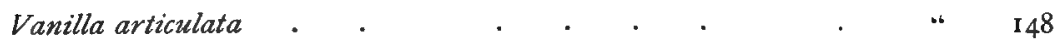

Phoradendron northropice. . . . . . . . . . $\quad$. 150

Pithecolobium bahnmense . . . . . . . . . . . 155

Cassia caribaa . . . . . . . . . . . . . . 456

Linum bahamense . . . . . . . . . . 4 " 159

Erythroxylon reticulatum . . . . . . . . . . 160

Crossopetalum coriaceum . . . . . . . . . . . . . . 40165

Reynosia northropiana . . . . . . . . . . 40166

Helicteres spiralis . . . . . . . . . . . " * 167

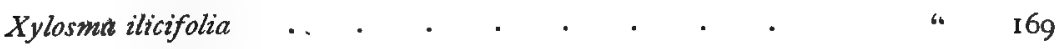

Terminalite spinosa . . . . . . . . . . . " " 172

Metastelma barbata . . . . . . . . . . . . 4 176 


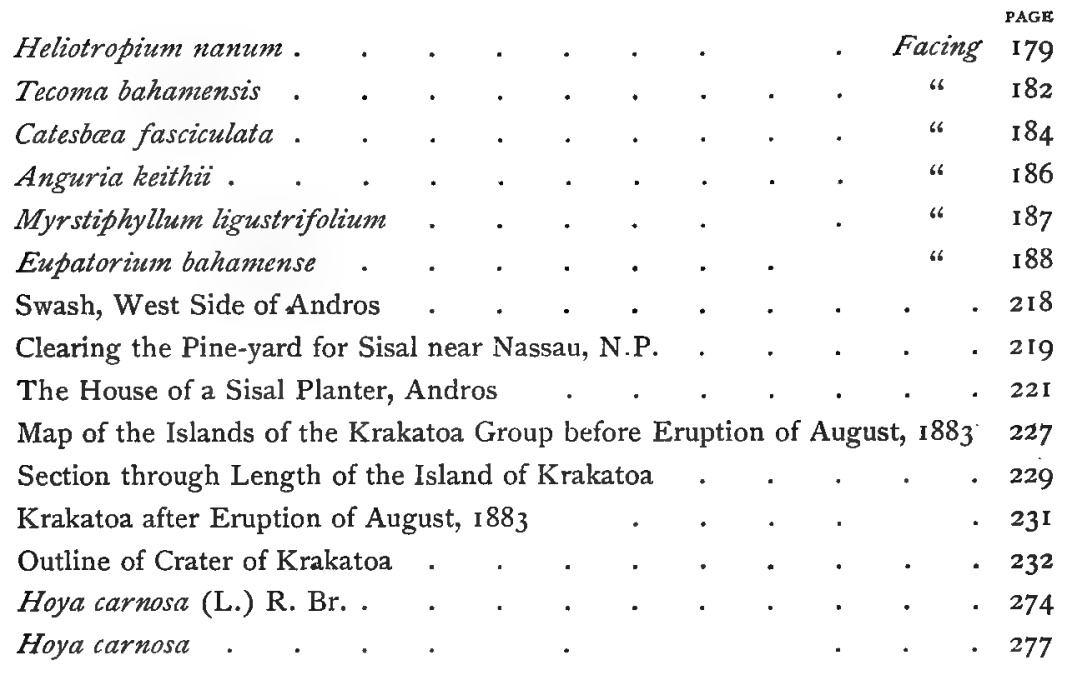




\section{INTRODUCTION}

JoHN I. NoRTHRop was born in New York City October I2, I86I. He was named after his father, John Isaiah Northrop, born near Rochester, N.Y., a pharmacist. His mother, Mary R. Havemeyer, was a sister of Frederic C. Havemeyer, a graduate of Columbia Col. lege, after whom Havemeyer Hall is named. His father died when he was two years old.

Dr. Northrop studied for some years at a private school in New Windsor, N.Y., then at the Columbia Grammar School, in which he prepared for the Columbia School of Mines. He graduated with the class of 1884 , with the degree of Engineer of Mines. While in college he was very fond of outdoor life, was a member of his foot-ball team, an enthusiastic fisherman, and interested in all outdoor sports. One of his former classmates narrates how he once saved a companion's life at the risk of his own. They were ascending a shaft at one of the Lake Superior mines on a man engine when his companion, some distance above, missed a step and was falling down the shaft. Young Northrop seized him as he fell and succeeded in holding him with one arm while he supported himself with the other, an act which called for a strong arm, quick action, and steady nerve, and showed that complete forgetfulness of self which was ever one of his most prominent characteristics.

Immediately after graduation he accepted a position in Havemeyer \& Elder's Sugar Refinery, but shortly afterward he journeyed to Deadwood, So. Dak., where he joined a former classmate, and together they opened an office as "mining engineers, chemists, and assayers." He returned to New York in the spring of 1886 because of the serious illness of his mother, whose death occurred shortly afterward.

It was evident that his tastes did not lie in the direction of engineering, and while the circumstances of his coming back to New York were sad, they proved to be the turning point in his career. $\mathrm{He}$ 
immediately came under the personal and most inspiring influence of Professor John Strong Newberry, the veteran teacher with whom he had studied geology and palæontology in Columbia College while preparing for his degree. He greatly admired Dr. Newberry, who perceived his talents and showed great confidence in his ability, and who also was warmly attached to him, treating him like "one of his own boys." On January 9, I888, he was appointed Honorary Fellow in Geology in Columbia College. Seizing every opportunity which the museum and his close acquaintance with Professor Newberry afforded, young Northrop rapidly made himself familiar with the principles of botany and zoölogy. He exhibited that breadth of interest which was such a marked characteristic of his master; but made a specialty of zoölogy, and delivered a series of lectures in this subject while holding his fellowship. He became a candidate for a higher degree, and in 1888 was awarded the degree of Doctor of Philosophy on the presentation of his two dissertations: "Histology of Hoya carnosa" and "Fossil Leaves from Bridgeton, N.J." The work on the Fossil Leaves from Bridgeton was carried on under Professor Lester F. Ward of the U. S. Geological Survey at Washington, and was ultimately to be published at Washington by the government. Previous to this he had published "Plant Notes from Temiscouata County, Canada," in the Bulletin of the Torrey Botanical Club, November, 1887.

After receiving his degree, in the summer of 1888 he accompanied Dr. Newberry to Colorado and assisted him in some geological work. On June 28, I889, he married Alice Belle Rich, at the time Tutor in Botany at the Normal College, New York City, a companion who shared all his scientific tasks and the value of whose assistance in all his work he never failed to appreciate and acknowledge.

Together they spent much of the summer of 1889 at Eastport, Me., and Grand Manan, N.B., dredging, shore collecting, and studying marine invertebrates. Dr. Northrop was an enthusiastic and indomitable collector and most careful observer, sparing neither time nor trouble to complete or render correct whatever he undertook. He never could stifle his sense of humanity through his enthusiasm as a naturalist. The following, as an illustration of his love of animals, is recited by Dr. Arthur Hollick: While at Grand Manan, during the summer of 1889 , he visited one of the little islands which the petrels had long used as a breeding-place. He took several of the 
young birds out of their holes in the ground, examined them carefully, and, to the surprise of his companion, returned them, not taking even one for a specimen, although the birds were comparatively rare, and he was not likely to have such an opportunity again. He explained that he could not make up his mind to take one of these birds because he realized that each mother bird had but one little one all summer. $\mathrm{He}$ used to laugh afterward at what he called his "foolishness," but this consideration for animals was one of his most charming characteristics.

In the early part of the year 1890 a journey to the Bahamas was planned. The islands of New Providence and Andros, especially, were visited and studied carefully. The amount and variety of material collected during this trip, which extended from January 2 to July Io, was remarkable; geology, botany, and zoölogy were all represented both in the collections and in the notes. From observations made on this trip were published his papers "Notes on the Geology of the Bahamas," "The Cultivation of Sisal in the Bahamas," "Birds of Andros Island, Bahamas." Among his unfinished works almost ready for publication were: "A List of Starfishes and Ophiurans collected in the Bahamas," and "A List of Sea-anemones collected in the Bahamas."

One of the birds collected on this trip proved to be new to science, and was described and figured by Professor J. A. Allen in the $A u k$ : January 8, 189I, under the name Icterus northropi. The sea-anemones were subsequently handed over to Professor J. Playfair McMurrich for description.

The report on the plants brought together on this trip was published subsequently by Mrs. Northrop and forms part of this volume.

The autumn and winter of 1890 Dr. Northrop devoted to the study and preparation of these collections. In the meantime his ability was widely recognized. He held membership in the Torrey Botanical Club, in the American Institute of Mining Engineers, in the Linnæan Society of New York, in the American Ornithologists Union, in the American Folklore Society, in the American Association for the Advancement of Science, and in the New York Academy of Sciences. He also was enrolled as a member of the International Geological Congress during the 1888 meeting.

During the winter of 1890 President Low and the trustees of 
Columbia decided to greatly extend the zoölogical courses of the college, and Professor Henry Fairfield Osborn was invited from Princeton to plan a Department of Biology for the institution. The result was the creation of a strong department, including a number of professors and instructors. On the 5 th of May Dr. Northrop was appointed Tutor in Zoölogy in this new department, especially in charge of invertebrates. In order to perfect himself for the duties which he expected to assume he obtained leave of absence for a year and intended to start during the early part of September, I89o, for Germany to study under Professor Hertwig in Berlin and Professor Haeckel in Jena.

At the very opening of this bright outlook for the future and attainment of this splendid preparation, in which Dr. Northrop had shown such rare ability and resourcefulness, came the tragedy of his sudden death, connected with the performance of his duties as curator of the zoölogical collections in the School of Mines Museum.

In the afternoon of June $25 \mathrm{Dr}$. Northrop had occasion to obtain some alcohol for use in the preservation of zoölogical specimens. As a measure of safety the main supply was stored in a fire-proof vault under the School of Mines building. Two janitors accompanied him, and together they proceeded to draw off some of the alcohol from a large cask into a smaller vessel. The vault was dark, and a match was struck in order to see how the vessel was filling. Just what happened we shall never know ; but the alcohol ignited, there was a momentary glare of flame around the faucet, a flash, an explosion, and a sea of fire in the vault. All three of the men were thrown down and badly burned, but evidently Dr. Northrop's clothing had become saturated with the alcohol, and his injuries were so severe that he died during the following night. On July 5, I89I, just ten days after Dr. Northrop's death, his son, John Howard Northrop, was born.

It is difficult to measure the loss to Columbia College, so soon (I896) to become Columbia University and to assume its important part in the scientific work of America. His memory will be perpetuated in Columbia by the Zoölogical Library which he was instrumental in getting together, through the generosity of his uncle, Mr. Charles H. Senff, and in the zoölogical material which he collected and arranged for the Zoölogical Museum.

The finished and unfinished work which Dr. Northrop left behind 
him gave evidence of acute powers of observation, of painstaking study, and of strict regard for truth in the recording of facts, qualities which are the prime essentials of a successful man of science. Perhaps the most notable characteristic of his mind was his keen appreciation of underlying causes in the investigation of facts. His excessive modesty gave him an appearance of reticence and reserve which was not always understood by those who did not know him intimately. To his personal friends this reserve was merely one of the evidences of his high motives and scientific idealism. His ideals were further manifest in the indifference with which he regarded the discovery and description of new species as compared with the study of their underlying structure and life history. He was inspired by a passion for scientific work and also a passion for truth, which, with the greatly enlarged opportunities opening toward him, would surely have enabled him to leave a permanent mark on American science.

Dr. Northrop had in mind the ultimate publication of a volume on the Bahamas which would embody the results of his work there and of other contemplated collecting trips to the islands, and this memorial volume was planned to represent the carrying out of that project of his so far as possible. The contemplated work would have been far more complete and more worthy of the author; but we trust that this volume, which includes all of his writings, largely brought together through the loving care of Mrs. Northrop, will form a permanent memorial of John Isaiah Northrop, so that the memory of his labors and activities, brief as they were permitted to be, may live, and the influence of his example be handed down to future generations of the students of Columbia and of other universities.

Henry Fatrfield Osborn. 



\section{BAHAMAN TRIP}

\section{General Notes}

\section{By AIICE R. NORTHROP}

DURING the summer of $1889 \mathrm{Mr}$. Northrop collected and studied the marine invertebrates of northern waters at Eastport, Me., and Grand Manan, N.B. He was anxious to follow this up with the study of southern forms preparatory to taking a place upon the teaching staff of the newly organized Zoölogical Department of Columbia University. Owing to the wealth of their marine life, a trip to the Bahama Islands was decided upon, and when we found that their flora was only imperfectly known, it was planned to make a collection of the plants also. A leave of absence was secured and over six months were spent on the islands, two on New Providence and the remainder of the time on Andros. The scientific results of the trip, as far as the material has been worked up, are given in the following papers. Below is a brief account of our journeys and such general information as has found no place in the special papers. The following narrative is compiled almost wholly from my husband's notebooks and well shows his keen powers of observation and the painstaking accuracy of his notes.

We left New York on Thursday, January 2, 1890 , and at dawn on the following Monday the steamer dropped anchor off the city of Nassau. We found it a picturesque place, with white roads bordered on either side by low-roofed houses, often embowered in vines and set in pleasant gardens. "The main thoroughfare and principal business street is Bay Street, running parallel to the water and extending east and west for several miles. A short walk to the west brings us out of the town. The roads and gardens are bordered with walls of coral rock, plastered all over or often on top only. In the parks and gardens and planted along the streets are cocoanut-palms, almond trees (Terminalia), with their dark green glossy leaves, Spanish cedars (Casuarina), the sand-box tree (Hura), and the silk-cotton tree or ceiba, 
with its spreading horizontal branches and buttressed trunk. The silk-cotton trees that have leaves show but few flowers, and the flowering branches are leafless. The trees that have flowers are one mass of buds. Although the silk-cotton tree is a native of more southerly islands, it flourishes on New Providence and is quite common about Nassau, as is also the beautiful "flamboyant tree" (Poinciana regia), from Madagascar. The latter has a dome of finely dissected, fernlike foliage, amid which, at the time of our arrival, hung the curious brown pods, two feet or more in length. On Andros, in June, the Poincianas were a mass of scarlet flower clusters, and as the leaves were not yet developed, the dome of flaming scarlet could be distinguished several miles from shore.

Almost all the inhabitants of New Providence live in Nassau and its environs, there being only a few small negro settlements on other parts of the island. In Nassau itself, said to have a population of about fourteen thousand, probably five-sixths of the inhabitants are negroes. These live principally in the suburbs known as Grant's Town, Bainville, and Fox Hill. Here their huts are close together and are generally surrounded by little gardens of cocoanuts, orange trees, and bananas. These Bahaman gardens look strange to Northern eyes, for the vegetation apparently springs from bare coral rock. The surface, however, is much weathered and very irregular, and the scanty soil and leaf-mould that collects in the holes is sufficient to support the luxuriant vegetation."

The chief boast of the people of Nassau is their climate, and after our six months' sojourn we concurred in their opinion that most of the time it was as nearly perfect as a climate could be. While we were on New Providence, the average temperature was about 75 degrees, from which point it seldom varied. From records kept by my husband on Andros, the greatest heat was recorded at Lisbon Creek on June 23, when it was 86 degrees indoors and 125 degrees in the sun. We had one "norther" while on New Providence, when the wind blew a gale for several days, raising a heavy surf on Hog Island and Salt Cay. The waves broke over the latter in places where it was thirty feet in height. This was the only storm of any account experienced during the entire trip. During the first four months there was very little rain. Later in the year heavy showers were frequent, although there was rarely a day on which the sun did not shine for a time, at least. 



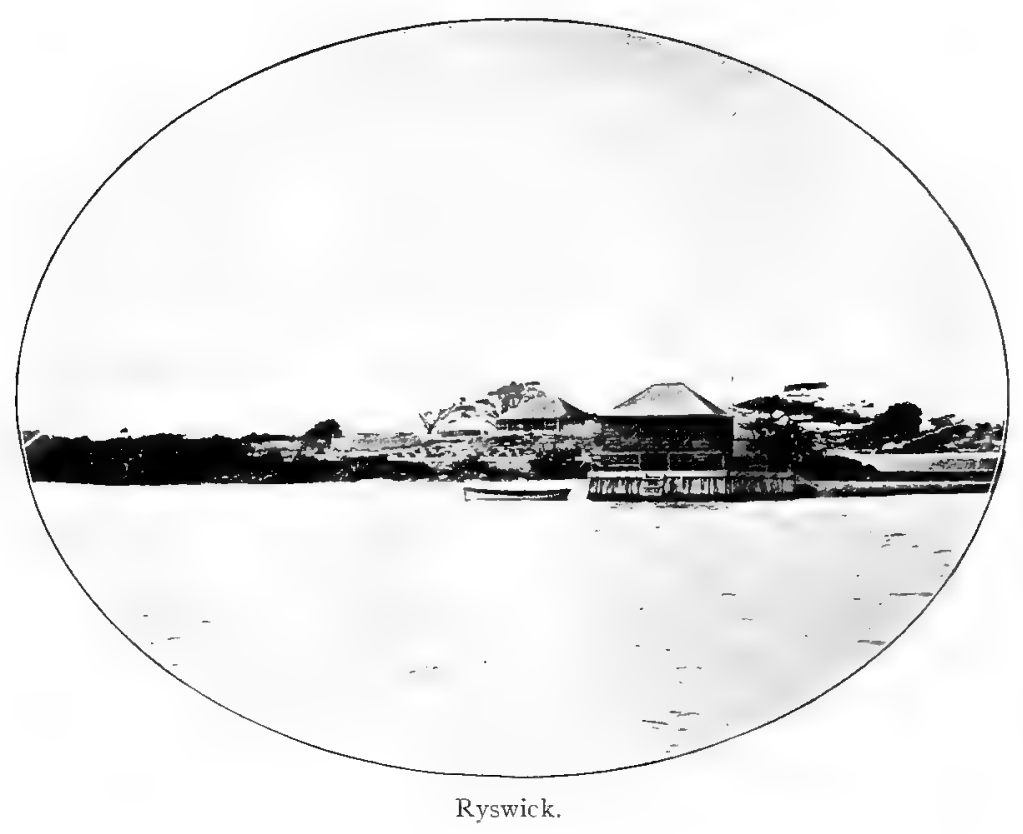


The greater part of our sojourn on New Providence was spent at "Ryswick," a country place which we rented of one of the merchants in town. It was about three miles east of Nassau and near the best grounds for marine collecting. The house was situated on the rocky coastal ridge and commanded a fine outlook. The gray walls of old Fort Montague were on one side and Dix Point on the other, while we looked across the bay to the low, wooded cays known as Hog Island and Quarantine. Beyond these could be seen the long narrow ridge of Salt Cay. A man and sail-boat were engaged, and day after day we sailed to the outlying cays and reefs and collected along their shores. The marine life was so wonderfully varied and abundant that for several weeks ${ }^{-}$we daily brought back starfishes, holothurians, crustaceans, corals, or sponges we had not found before. Dix Point and the sand flats in front of the house also proved profitable collecting grounds at low tide. Occasionally we would try dredging, but the coral heads and blocks made it difficult work, and we did not find it as productive as shore collecting. What is termed the "sea-garden" is near Ryswick. Here one looks down into a forest of alcyonoid corals, pink, brownish, and yellow, while scattered over the bottom were large sponges, some round and inky black, others clustered and purple-tinted, also huge brain corals interspersed with many of the delicate branching madrepores. Gaily colored fishes darted about, the most striking being bright blue, while others showed yellow bodies and blue tails or were silver spotted with crimson. The water was so wonderfully clear that it was difficult to be convinced that these marine treasures were not within easy reach. We also visited the living coral reef off Rose Island, some miles to the northeast, but the reef we saw later along the east coast of Andros was much larger and finer.

The principal work at New Providence was the collection of marine invertebrates, but between times, and when it was too rough to collect, we explored the island in many directions, visiting the south side, the southwest beach, the extreme eastern end as well as Lake Cunningham and the caves to the west of Nassau. Two or three hundred species of plants were collected on these trips as well as some birds and insects.

Jamuary II. Drove across to south side of island. The north side, just back of the town, is a rocky ridge; then comes a comparatively 
level space containing cocoanut plantations and a small patch of sisal hemp. In the uncleared lowlands Pinus Bahamensis covers the ground. The higher parts are covered with angiosperms. Near the water the land is very low, the soil soft and calcareous. The only vegetation seems to be numerous, small, scattered mangroves and a few buttonwoods (Conocarpus).

February 3. To Lake Cunningham. Followed the road through part of Grant's Town, then a winding road leading through a pine barren for about five miles in a general southwesterly direction. Crossed a number of ridges running north and south. Noticed some large banana holes. The pines have mostly been cut down, and the ground is covered with a second growth. At the eastern end of the lake is a mangrove swamp. The lake is perhaps a mile and a half long and about a half of a mile wide. The water is slightly brackish. A great number of shells on the bottom, near the shore; collected some (determined as Arca Jamaicensis by Dr. Dall). The drive home showed the lake to be quite close to the sea. The country to the west of the city is quite flat.

February to. In evening walked to Fort Montague. Water very calm. Saw a worm about an inch and a half long swimming through the water and leaving a bright phosphorescent track. Came back to house to get glasses and net. Walked out in water. The bottom was phosphorescent, every step causing it to scintillate for a circle three or four feet in diameter. Agitation of the surface produced no light. Here and there at the bottom were small glowing spots which appeared to be bivalved crustaceans.

February 20. Fishing at sea-garden. The noise made by market fish and grunts is produced in the following manner: The upper pharyngeals are drawn together and backward; the lower is pushed upward and forward, thus grating on the other two. The noise is slight, resembling that made by the finger-nail in scratching across the grain of a board.

February 2I. Shark fishing to the north of Salt Cay. Caught one known as a mackerel shark. Color dark steel-gray above and on sides, as far as line between pectoral and ventral fins, below this a pure white with only few blotches of gray, to anal fin, behind which the gray predominates. The nictitating membrane is white and slides over the eye from below. The teeth are serrated, with a deep notch in the 
outer side so that the point projects outward. Nostrils are double, the one nearest the median line being covered by a flap of skin. The head viewed from above is very obtuse, almost truncate, and the eye is just visible; gill openings fine. There are two dorsals; one, slightly in advance of half the distance between the pectorals and ventrals, is about as high as long, with a point projecting behind half as long as base of fin. Second dorsal is almost opposite the anal fin, but slightly in advance of it. There is a pit at base of caudal fin, both above and below. The upper lobe of caudal fin twice as long as lower lobe and has notch in lower edge near the end. The ventrals are quite.close to the anal, so that the subcylindrical claspers touch the anal. The pectorals are large and are continued behind near the base. Length of shark from fork of tail to end of nose, 8 feet 4 inches; from tip of tail, Io feet 4 inches. Parasites taken from shark: (I) A Remora-like fish; (2) a crustacean found in gill-slit; (3) leechlike parasite from roof of mouth one and three-quarters inches in length when fully extended.

March 5. Dug for Balanoglossus in the sand near Dix Point. Their holes are marked by a pile of castings. The holes extend downward, usually with a curve, to the rock. Followed one of the holes down straight about ten inches, then along in a spiral for about eighteen inches to the rock, where I found a Balanoglossus. Followed two more holes, but lost them before reaching the animal. When found, the whole animal is surrounded by a transparent gelatinous coating. Laid one on paper; when extended, it is twelve inches in length. Put one in fresh water, caused strong contraction; added some alcohol to salt water, caused contraction and a discharge of mucus, like the white of an egg. Shortly after added considerably more alcohol.

March 6. Balanoglossus in very bad condition this morning. They are coated with mucus, and so soft they will hardly hold together.

[July 5. (After our return from Andros.) Went out to Ryswick and dug more Balanoglossus. Some were over two feet long. When an animal was laid on paper, the slime was strongly luminous with a greenish light that was visible within five feet of a strong kerosene lamp. The light was strongest between the folds of skin near the center of the body.]

After two months collecting on New Providence, we found little new material; the supply of alcohol was nearly exhausted, and we 
decided to select some other island for our botanical work. Andros was chosen as being the largest and least known of the group. Although the nearest part of this island is only twenty-five miles from New Providence, we could get but very meager information concerning it. The Nassauans know scarcely anything of what they rather contemptuously designate the "out islands." Every one tried to dissuade us from going to Andros, assuring us that "there were no white people, no roads, and nothing to eat." We were finally fortunate in meeting Mr. Alexander Keith, of Edinburgh, who had just bought two thousand acres on Andros and started a sisal plantation. He kindly told us of a little house we might hire at Nicol's Town, the most northerly settlement. We added a camping outfit to our baggage, hired a sloop, and then, with all our goods and chattels packed, were fain to wait ten days on the pleasure of the wind. We had just had a heavy "norther," and our captain could not be persuaded to start as long as the winds were high, the east coast of Andros being fringed with a dangerous reef and without a single harbor. Finally on March I4 we crossed the Tongue of Ocean, making the thirty-five or forty miles in about eight hours. We passed through a narrow opening in the reef and disembarked at Nicol's Town on a beautiful, curving, white beach with thatched huts showing here and there through a fringe of waving palms. The justice of the peace, a stalwart negro, welcomed us to Andros and led the line of march to the "mission house," where we were to stay. A large contingent of the villagers followed, bearing our boxes and various pieces of baggage on their heads. The house was only eighteen and a half by ten feet, but it was divided into two rooms and boasted two doors and six windows. It was what is called a "tabby house," one made of coral blocks, plastered inside and out. Daylight could be seen here and there through the shingled ror rise of ground, a little apart trees were in bloom just $c$ "he house was prettily situated on a , ie rest of the settlement. Orange the windows, and gum-elemi and cassada trees shaded the doos ${ }_{u}$ rd. The gum-elemi proved a great attraction to the birds, and there would often be seven or eight on it at once, representing three or four species. The most frequent visitors were the mocking birds, cat birds, the Tom-James bird (Spindalis zena), and the grassquit (Euetheia bicolor). When we passed from the coppet to the pine-yard, these were replaced by the blue- 


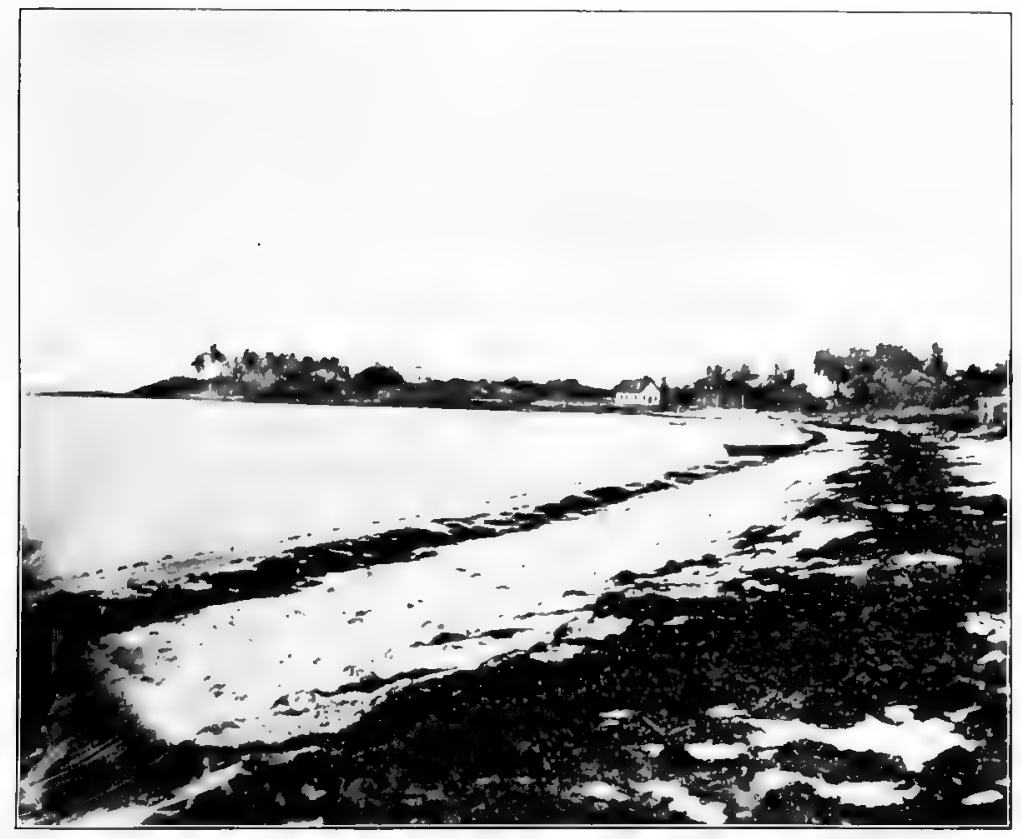

The Bay at Nicol's Town.

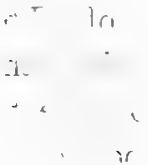



gray gnatcatcher, the pine warbler, and the beautiful little hummingbird known as the wood-star.

We made. Nicol's Town our base of operations for about seven weeks, collecting in the immediate neighborhood and also making a number of more extended trips. As comparatively little seems to be known of the interior and west side of Andros, the following account of our journeyings is given in considerable detail. "Nicol's Town itself was a straggling village, having, according to Mr. Davis, Justice of the Peace, a population of 'three hundred and odd.' There were three churches, Methodist, Baptist, and Episcopalian, and still another was in process of construction. There is a schoolhouse and a small jail on the hill; the latter is said to be generally empty. The houses here are mostly square and are either built of coral rock like ours or are of timber with smaller sticks interlaced or 'wattled' on which the plaster is laid. They have sloping roofs thatched with palms. There is but one well in the village, and the water in that rises and falls with the tides. It is very poor, hardly fit to drink; even when boiled it has a brackish taste. We mostly use jelly-cocoanuts and oranges when we can get them."

March 26. The weather is cold, thermometer 62 at 6.40 P.M. A hard northeast wind is blowing. In the morning walked along the beach north of the village, passing through a grove of cocoanut-palms with here and there a few houses. Some of the trees had been blown down, but continued to grow so that while about twenty feet of the trunk lay on the ground, six or eight feet was growing upwards at right angles to the rest. As the roots were almost entirely out of the ground and resting on one edge, and as I did not see any secondary roots at the bend, it would seem as if the cocoanut required very little nourishment from the soil. The beach along which we walked for about three miles was fringed with the sea-grape (Coccoloba uvifera), back of this for most of the distance were three rows of cocoanutpalms. The few houses stood back of these, and behind the houses was "the bush."

March I7. After breakfast shot some birds. We then walked a short distance through the village, turned south into a path leading past a few scattered houses, a new sisal field and in about threequarters of a mile reached the pine-yard. The path was just wide enough for single file, and on each side the trees and shrubs made an 
impenetrable bush. The path was exceedingly rough and at times passed close to the edge of deep banana holes. In the pines saw some rain crows (Crotophaga ani). Insects seemed very scarce; caught two butterflies. The largest pine seen was about twenty-four inches in diameter and about fifty feet high. The bark is gray, quite rough and detaches easily in flakes, leaving the exposed part dull, reddish brown. The branches are near the top of the tree, and the leaves towards the ends of the branches. The cones are very numerous and are sessile below the leaves.

March I8. Started with Mr. Davis (the justice of the peace) to visit some caves near Morgan's Bluff. On the way we called on a Mr. James, who took us to see his cave, a long, low chamber on the side of a hill. Some of the openings were about thirty feet in height, and from the overhanging rock, which was about three feet thick, hung down the long aërial roots of a Ficus, making great bars across the mouth of the cave. Near by was what is called the "sea-hole or ocean hole," perhaps a hundred feet in diameter and from twenty to forty feet in depth. (See account of the geology.) After visiting this we continued our walk to Morgan's Bluff at the northern end of the island. The rock here was quite precipitous, much water-worn and about fifteen feet in height. The cave which was near here had a small entrance about the size of an ordinary door. A second opening led into a larger room in which we could stand erect. Found a human humerus on the ground. Mr. Colby, the owner of the cave, said that all the earth had been taken out about thirteen years before, sold for a dollar a ton and taken to Port Royal, S.C. He also said that he had collected the bones and buried them again. On the roof of the cave a number of small stalactites showed that the water dissolved some of the lime as it trickled through. On the return trip Mr. Davis showed us what are here called "cinnamon trees" (Canella Winterana), also the mahogany and madeira trees. The so-called "road," in reality a narrow path, was very rough, and we were tired when we reached our cabin, although we had only walked about eight miles.

March 20. Found some large soldier-crabs under a stone, and this evening when I went out to open a cocoanut, I saw eight or nine of them around the place. I watched them feeding on the cocoanut jelly. They seem largely nocturnal in their habits. Caught and preserved two males. 


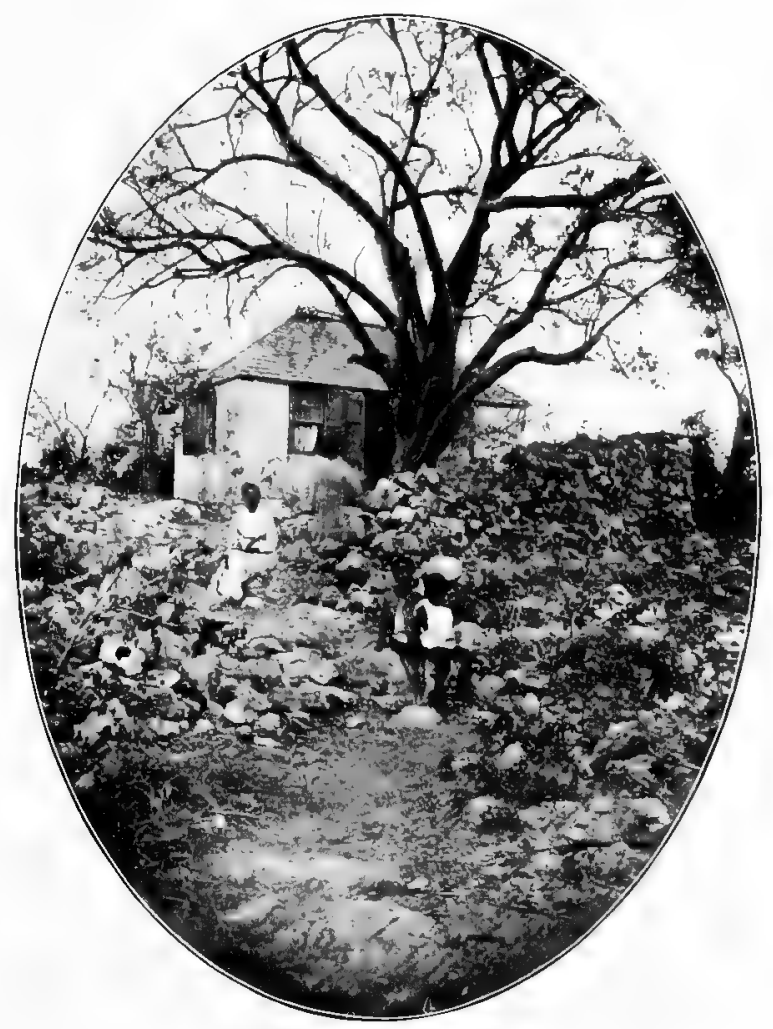

Our House at Nicol's Town. 

March 2I. Boy brought some lizards. One had its tail broken off. I placed it on the ground, where it opened its mouth and kept facing my hand, at the same time distending its gular sac in evident anger. This shows that the extension of the gular sac is sometimes a mark of anger, still it is possible that it might have been pain.

March 29. In afternoon walked to Cocoanut Point, about a mile and a half south. Very warm. Road mostly over the rough rock on the shore, the rest on sand under the cocoanuts. A little distance beyond the point were met by Mr. Keith, who sailed us to his sisal plantation on Conch Sound about five miles away. We had a fair wind and soon entered the sound, and in a short time were sailing through a winding creek, bounded on each side by mangroves. The house stood in a small clearing surrounded by pine trees and a coppet of smaller hardwood trees. A short walk through the pines took us to the sisal field. Mr. Keith has cleared about three hundred acres of his land and has it partly planted. Our path was an old road, where we could plainly see the marks of wagon wheels, said to have been made about fifty years before, during the slave time. Near the house is a large chimney and the remains of a generous fireplace. Many swallows were flitting over the clearing.

March 30 . Walked along a path through the woods near the shore and found a number of plants we had not seen at Nicol's Town. There were many bromeliaceous plants and a number of orchids, some in fruit and a few in flower. On the return to Nicol's Town saw in the shallow water of the creek what was known as the "boiling hole." (See notes on geology.) There were a number of large fish in the hole. These are sometimes obtained by pounding up the bark of one of the native trees (Ichthyomethia piscipula), placing it in a sack, and sinking it in the hole. This is said to stupefy the fish, which then float to the surface.

Monday, April I4. Left Nicol's Town in a small sloop, the Herald, for a short trip to the west coast. The Herald was about one ton burden and drew from one to two feet of water. It was manned by a negro captain and cook. Mr. Keith accompanied us. Passed the end of the reef a short distance above Nicol's Town; shortly after went around Morgan's Bluff, the rocky precipitous cliff fifteen or eighteen feet in height that forms the northern end of the island. We reached Lowe Sound about noon, then sailed for a long distance in 
shallow water; long sand-bars, some exposed and some under water, and a few cays showing to seaward. On one were a number of terns and a pair of oyster-catchers. Shot one of the latter; as it fell in the water a barracuda snatched at it, but was beaten off by one of the men with a harpoon. There were a number of sharks about, some five or six feet in length. Although our boat drew less than two feet, we were stranded on a sand-bar until four o'clock. As a consequence it was dark when we landed at Red Bays on the west side of the island. As walking about at night is impossible, we did not attempt to reach the settlement, but slept in a palm-thatched chapel near by.

Tuesday, April I5. Walked a short distance back of the settlement of Red Bays. The land was low, covered with palmettoes and the brier tree (Terminalia, one of the plants which later proved to be undescribed). Returning farther down the shore, first met with the marly deposit so characteristic of the west side. It is a very fine deposit, and so soft that in some places I sank in halfway to my knees. It extends back from high-water mark from an eighth to a quarter of a mile. In some places along shore are mangrove swamps. There were also some mangroves beyond high-water mark, but these are small and apparently not thriving. About two miles below the little chapel where we had spent the previous night, we again turned inland across a savanna, a piece of level land covered with grass and rushes, where we found a number of plants new to us. (See account of the flora.) We then entered the pines and followed the path to an orange grove in a coppet, known as Lewis Coppet, where the house that had been vacated for us was situated. After some discussion three shillings currency was agreed upon as the price of rent per day and two shillings sterling to be paid the wife for the five days' cooking. This, I may say in passing, was higher than the usual rates asked.

A pril I6. Mr. Keith left. Very warm, thermometer 82. The walking is very rough, but not as bad as back of Nicol's Town. There are many banana holes. The soft soil covers the depressions in the rock for a long distance from the water.

April I7. Out shortly after dawn. Followed a path through the coppet southwest, then on through grass and palmettoes to a small patch of woods beyond. Near here there was an agave in bloom, the first we had seen. The flower stalk rose about twenty-five feet in the air and was about eight inches thick at a distance of four or five feet 
from the ground. At the top the branches were thickly covered with the golden blossoms. These are a great attraction to the birds, as we have seen about it a number of the cocoanut birds, the Bahama flycatcher, and the Cape May warbler. The latter was seen sipping the liquid in the flowers. Many insects and humming-birds are also flitting about them. (It was here that we first saw the males of the bird that proved to be an undescribed species of oriole later named after us by Dr. Allen.) Shot off some of the flowers.

A pril 19. Up at sunrise; walked out to the agave again to take a photograph. A short distance beyond the agave the palmettoes grew fewer and fewer until at length there was nothing but the scattered mangroves and here and there a clump of the prickly "brier tree." Farther yet nothing to be seen to the south and southwest but a level plain dotted with small mangroves. To the north, a dark line of pines was discernible. The rest of the day was spent in shooting and skinning small birds. They were unusually numerous about the house. For several days numbers of warblers arrived during the night, evidently migratory birds on their way north. Having heard that flamingoes, in native parlance "filimingoes," were plentiful some miles farther down the coast, we decided to make a trip there after spending five days at Lewis Coppet.

April 20: By 7.30 A.M. we were down at the boat. Got in the small boat and were pushed out by the men halfway to the larger boat that lay almost aground over a quarter of a mile from shore. About I2.30 we landed at a place called Cedar Coppet. The beach at highwater mark was composed of the same fine chalky deposit as at Red Bays, but it was whiter. The pines here come within a quarter of a mile of the shore, only a mangrove flat lying between. We left Cedar Coppet about two and sailed down the coast to what the men called Loggerhead Creek, but which seems to be the Deep Creek of the maps. It was about twenty-five miles south of Red Bays and was the first creek of any size passed. It was a little over a quarter of a mile in width at the mouth, but soon narrowed to about seventy-five yards. Sailed in a short distance and anchored; the tide falling, we were soon aground. The shore was very soft, white above, blue gray beneath. Back of the bordering mangroves was a bit of coppet on a slight elevation where we made a lean-to of palm leaves for the night.

April 21. Went up the creek about a mile in the small boat, then 
left it and walked to a small pond. The land was level as far as we could see, with the exception of a small coppet here and there. A walk of about three-quarters of an hour brought us near a pond, and in the distance we could see a scarlet patch, our first sight of flamingoes. We got within about three hundred yards when they flew away. There were four of them. We walked to another lake where we saw five more, and I got within two hundred yards when they too flew away, looking very brilliant and showing the black of their wings. Walked to a large mangrove in the lake and shot a switching-neck, a blue crane, and two long-shanks. Walking in the lake was exceedingly difficult, the water being about three inches deep and the mud, into which I sank at every step, eighteen or more. The "tell-bill-willy" was very common, its shrill notes being heard on every side.

Walked three or four miles farther to "Two-camp Lake," which was so extensive we could see neither end of it. All the ground about here is said to be covered with water in the "wet weather," in June and July. These lakes are evidently low places from which the water does not drain. It is strange that they contain so few mangroves, only one or two large ones, while on the shores they are scattered thickly.

A pril 22. Very strong northeast wind. Left our anchorage about five o'clock and sailed to the mouth of the creek, where we lay until midnight, when we got under way. Skinned birds on deck all the morning, and by three o'clock we anchored at Red Bays; spent the night in a thatch hut about nine feet square and about six feet high in the center; it had a door of thatch and no windows. The ground back of the settlement is rough, but not as bad as at Nicol's Town.

Wednesday, April 23. Beat all day against wind and tide on the return trip to Nicol's Town; wind blowing too hard to let us go around Morgan's Bluff, so we landed at Money Cay in Lowe Sound and walked to the village.

Friday, April 25. Walked to Cocoanut Point, left the path and walked back into the woods, had hard work to get through the bush. Saw a number of bromeliaceous plants and found that some of the orchids were in bloom. In the spreading base of the leaves of one of the former plants, a species of Tillandsia we had not found before, a colony of ants had their home. The thorax was brownish red, the abdomen black and pointed behind. They have stings, and when 
running about after being disturbed carry their abdomens elevated, as scorpions carry their tails. A number of pupæ were noticed.

Tuesday, April 29. Visited the reef this morning. Inside the main reef is a smaller reef of large coral, called "red coral" here, the same as the large specimens from Rose Island; some were twelve inches in diameter. These grew thickly together, and their flat spreading branches were very handsome. In some places were masses of dead coral that showed cavities and holes similar to those on shore. The water inside the reef has a depth of two or three fathoms in the deepest parts, but outside gradually deepens. The main reef is about a quarter of a mile from shore. From half to three-quarters of a mile from shore the depth was found to be from fifteen to eighteen fathoms. At ten fathoms the water was so clear that we found objects on the bottom could be quite plainly seen through a water glass; at eleven to twelve fathoms the bottom could be seen and objects of different color easily distinguished. At fifteen fathoms only the dark and light patches could be made out. We were taken to a hole that proved to be a sandy space about a fathom deeper than the surrounding level. The bottom inside the reef, and outside also, is said by the sailors to be as "hard as rock." In some places fragments of coral lay on the bottom in the same manner as I have seen them on the land. [Of this Andros reef, Professor Alexander Agassiz, in his "Reconnoissance of the Bahamas and the Elevated Reefs of Cuba in the Steam Yacht Wild Duck," January to April, I893, says, "This reef, though narrow, is one of the finest reefs I have seen, and the patches of corals and Gorgonias which flourish between the reef and the shore are not surpassed in beauty by the corals of any district known to me."]

We had spent six or seven weeks at Nicol's Town collecting plants and birds, and towards the close of April prepared to go on to Conch Sound, four or five miles farther south, where we had made a brief visit a month before.

Wednesday, April 30. Mr. Keith came for us in his boat, which was soon loaded with our baggage, while we decided to walk. The path for the greater part of the way led through the pine-yard, and here and there through a coppet, until we neared Conch Sound, when it skirted the water until we reached Mr. Keith's house. The evening was beautiful with a clear moonlight night. The "tell-bill-willy" of the willet was almost constantly heard, and there were frequent 
splashes in the creek, presumably made by the barracudas. Conch Sound is a shallow inlet or bay, filled with small cays and mangroves and with a narrow winding channel. In places on the shore were great piles of the shells of the conch (Strombus). It is quite an important article of food on Andros, and it is in these shells that the pink pearls are found for which the Bahamas are noted. While Conch Sound was our headquarters, in company with Mr. Keith, we made a trip to London and Stafford creeks, eight or ten miles down the coast, stopping at Mastic Point on the way. An account of the trip follows.

Friday, May 2. Left Conch Sound about 9 A.M., wind nearly dead ahead. A hard rain fell just before we reached Mastic Point. When it ceased, we had our luggage carried to the house of Mrs. Bain, where we were to stay. It is a small settlement of not more than ten or fifteen houses built close together. It might well be called "Bainville" as everybody was related to old Mrs. Bain, our hostess, who was the patriarch of the settlement and whose mother and father were fullblooded Congos. The houses were better and neater than at Nicol's Town, some even had a little porch at one end, while others had brightly painted woodwork. Several had flowers planted about the dooryard. Mrs. Bain's house boasted a plastered floor, which was kept neatly sanded, and some fine pieces of mahogany furniture. There was, as usual, a table covered with an array of glassware and crockery, such as goblets, decanters, wine-glasses, lamps, and lamp chimneys. It is curious that these articles are never seen in use, but are evidently regarded purely as ornaments.

In the afternoon walked a short distance along a path through the mangroves. In some places where the rocks were overflowed by the tide, there were many sharp and jagged points. Later walked through a field where I noted corals in the rock and picked up a fragment. Beyond and farther inland was a slight elevation, on the south side of which the rocks were abruptly worn off, their appearance showing that the sea had once washed against the top of the hill.

Saturday, May 3. Started about seven o'clock in the morning, but were no sooner under way than there was another hard shower, lasting nearly an hour. The men poled a good part of the way, and we finally reached a large mangrove which was about one hundred yards long and fifteen to twenty wide. A pair of cormorants were perched on one of the top branches, and in the mangrove were many Louisiana herons 


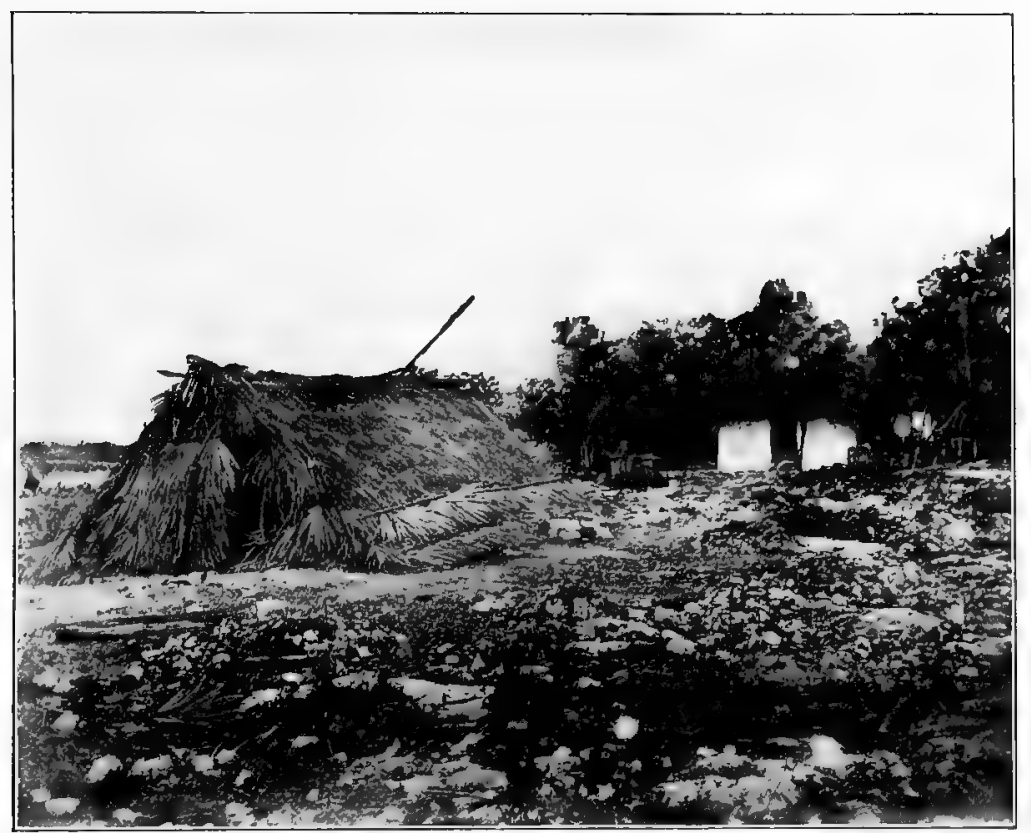

At Conch Sound. 

which the men called "blue cranes." There were a number of their nests in the mangrove, a few of which contained greenish eggs. Shot two of the birds. We sailed on to Wax Cut Cay where we had lunch. Near the shore were many Strombus shells which varied considerably in shape. In some the outer edge of the aperture was thin and extended, while in others it was much thicker and narrower. The men called the thick-lipped ones "sambo" and the others the "broadlipped conchs." We found some intermediate specimens which were thickened but otherwise like the broad-lipped, so perhaps the sambo conch is only an old broad-lip.

From Wax Cut Cay we sailed to Stirrup Cay, then past Rat Cay and Stump Cay, and between four and five o'clock poled up what we supposed was London Creek, but after proceeding a short distance, could see an opening through the cays seaward, showing we were not in the creek at all. Went about four miles farther and then anchored for the night, pitching our tent on low ground covered with undergrowth and with a few pines.

Sunday, May 4. Up early, troubled by sand flies. A short distance above our camp, we entered London Creek. The men say that the land to the south of us is a cay without a name and runs up to a lake at the head of London Creek, with which Stafford Creek' is also connected. Our general course was nearly southwest, with many turnings. The creek in some places was narrow, but as a rule was perhaps an eighth of a mile in width. The water was only two or three feet deep, and the bottom muddy. In one place the whitish slimy deposit was six feet three inches in depth. The course of the creek was through the pine-yard; in many places the pines and palmettoes came down to the water's edge, while in others it was bordered with mangroves. We sailed and poled up about six miles until the water became too shallow for us to proceed. We walked a short distance through some swash, and then through pines, hoping to reach a lake that the men said was four or five miles off, but a heavy shower threatening, we made our way back to the boat. After the rain stopped we sailed back out the creek and down to Calabash Cay, at the mouth of Stafford Creek. Spent the night in an unoccupied new house.

Monday, May 5. Found Stafford Creek entirely different in character from London Creek. The mouth was only about sixty feet wide, the water six or seven feet deep, and the current swift. After 
running west for a short distance, it turned abruptly to the south and spread out into a lake-like expansion about half a mile wide. The shores are of hard coral rock, and the pines come to the water's edge. It narrowed again and finally became a deep narrow winding stream that was fresh for the last mile or more of its course. At the extreme head the water became shallow, the bottom rocky in places, and the current quite strong, while numerous small streams trickled down the steep banks, into which some had cut quite deep channels. This narrow fresh part is called the "lake." It was here that we collected two species of bladderwort (Utricularia), the only fresh-water plants that we saw in the entire island. We must have penetrated twelve or thirteen miles into the interior, through pines and palmettoes all the way until we reached the head where we found swash running back perhaps two or three miles. In some places the ground was covered with mangroves for a long distance. Altogether the landscape looked very much like that of the west coast. We left the head of the creek at about three o'clock and reëntered the broad lake-like part about five, camping at six on the north shore. Here the creek is half a mile wide; to the west it extends for two miles, and you can see three or four miles to the east. It is bordered by pines with an undergrowth of palmettoes and brier tree.

Tuesday, May 6. Left Orange Landing, where we had camped, a place with a house and a few orange trees, at about 8 A.M., reached the mouth of the creek at about eleven. Here we saw Cacti for the first time, the "dildo" (Cereus Swartzii) which grew ten or twelve feet in height. (We found them quite common at Deep Creek later.) Yesterday the "doctor flies" were thicker than the men had ever seen them. These troublesome flies attack the feet and legs especially and inflict quite a painful wound. They troubled the men much oftener than they did us. About half-past eleven we started on our return trip and reached Conch Sound about half-past eight in the evening.

May I3. Our next undertaking was a walk across the island, from Conch Sound to the west side. Apparently no one had ever gone that way, for the men were unable to give any idea as to how long it would take. On May ז3, 8 A.m., we left Mr. Keith's with four men and provisions for four days. Took a road through the pines, and in a half hour reached the beginning of Johnson's Coppet, a rocky ridge rising in the midst of the pines and covered with a hardwood growth. Here 
the banana holes were more numerous than anywhere we have been. Some of them were twenty-five feet in depth, but the majority only ten to twenty feet deep and perhaps eight to ten feet in diameter. Others again were shallower and only four or five feet across. Many of these holes were lined with drooping fern fronds, the most conspicuous being the maiden-hair (Adiantum tenerum) and the creeping Goniopteris, the latter with fronds often two feet or more in length and rooting at the tip. After a short rest entered the pines again. . There was no path beyond this, and we were obliged to cut our way through a dense growth of brake, the fern commonly called "Maypole" here (Pteridium caudatim). It was eight or nine feet in height. The ground was exceedingly rough, and the weather warm. The course thus far has been nearly southwest, and we have gone about four or five miles. The pines here are mostly seven or eight inches in diameter three feet from the ground. Some of them are larger and very tall, eighty feet at least. Passed through a tract covered with what the men call "bedgrass," a species of Andropogon; then through Maypole again. A few palmettoes and cycads begin to appear. The rock is soft, but very jagged. Measured a large pine here and found it to be 4 feet 9 inches in circumference, about seventy feet high. A short time after this the pines began to be smaller and smaller, the palmettoes more numerous, the rocks rougher and harder, and banana holes more frequent. Now, at one o'clock in the afternoon, the pines are only three or four inches in diameter; keeping on over a very rough piece of ground, we finally see light through the pines. We reach the end of them about two o'clock and look out over a level stretch of ground like a prairie with a coppet on the horizon in the distance, the men say it is mangrove. To the southwest a long point of pines with water showing on this side. The level ground before us is very soft and damp, a sheath-knife does not reach rock.

Wednesday, May I4. Left camp and started on the return trip a little after nine, reached Mr. Keith's about half-past two.

Leaving Conch Sound May 22, we next went to Mastic Point, four miles below, where we stayed at Mrs. Bain's, as before. Made several trips to "the big mangrove" three miles below, where I secured a man-of-war bird. Also got a number of other birds and plants not collected before. A number of the days were more or less rainy. After exploring the neighborhood, we secured the Herald again for a month's 
cruise about the southern end of the island. Left Mastic Point Tuesday, June 5. Our first stopping place was to be Fresh Creek, fifteen miles or so down the coast. We passed Rat Cay, Stump Cay, Saddleback Cays, Calabash Cay, and the wind getting light, we ran into Stafford Creek and spent the night there:

Wednesday, June I4. Beat all day against a southeast wind; reached Fresh Creek in the evening. There is quite a large settlement here, and the creek more nearly resembles a river than any we have seen. At its mouth it is from fifty to seventy-five yards wide. The banks are rocky on one side, eight or nine feet high, the water deep and the current very swift. There is said to be no reef off the mouth of this creek.

Thursday, June 5. In the afternoon walked along the "government road," the only path at all worthy of the name that we had seen on the entire island. It was about ten feet wide and connected Fresh Creek with a settlement at Calabash Bay, about four miles northwest. It runs through the coppet all the way, with here and there a field. Found a number of plants not seen before, among them a pretty orchid. The great white land crabs are unusually abundant about here. We have had numbers of them about the house, and several times have seen long processions of them walking near the edge of the bluff. They frequently touched the ground with their claws and put them in their mouths. Were they feeling for water? The people here say they go to the water to breed. I think there were more males than females, and the latter had no eggs under the abdomen. These crabs are common all over Andros and do great damage in the fields, eating the melons, tomatoes, corn, and even the bananas, we were told. Whole boat loads are taken to Nassau for sale in the market, and the men said they were less plentiful than formerly; on New Providence they have been largely exterminated.

Friday, June 6. Went out to Goat Cay, that lies off and slightly above the mouth of Fresh Creek. It is about three-quarters of a mile long and perhaps fifty yards wide. Here were numbers of the bridled tern (Sterna anathetus) which the men called "egg birds." They flew about us and followed us around in an inquisitive manner, uttering among other notes a sharp "cur cur cur-r-r." They were so tame it seemed a pity to shoot them. A flock of noddies (Anous stolidus) flew back and forth on the seaward side of the cay but they were much 



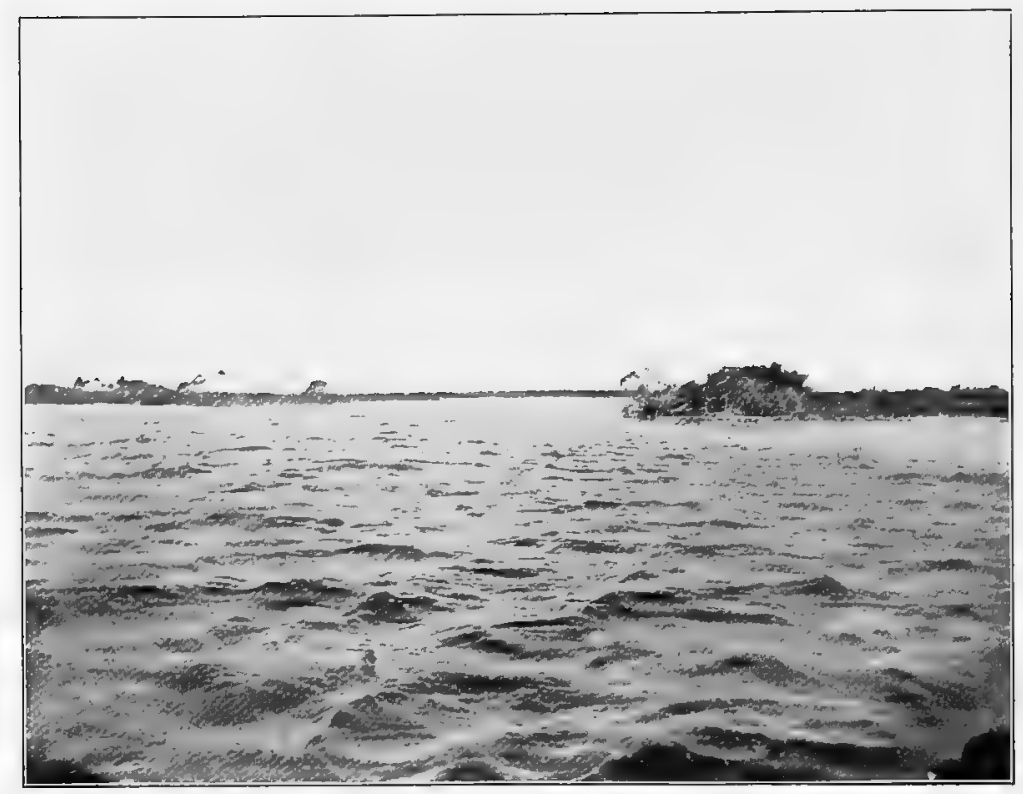

Fresh Creek. 
more shy. The southern end of the cay was lower than the other, being about six feet above the water. The surface was exceedingly rough, the rock being worn away so as to leave vertical, more or less cylindrical, columns varying from a few inches to over a foot in height.

Monday, June 9. Left about 7 A.M. and sailed up the creek with a southeast wind. The course of the creek is first through the coppet and then enters the pines. It widens once or twice and seven or eight miles from its mouth spreads out into a lake-like expansion, from three to five miles wide, containing small cays and mangroves. We sailed to the head of navigation and then poled in the small boat until we reached fresh water. Fresh Creek has two or three arms and must penetrate twelve or fifteen miles into the interior. In very wet seasons there is said to be water communication with Wide Opening and the lakes on the west side. We spent a couple of weeks at this settlement, finding the flora more varied than farther north. The thermometer ranged between 82 and 84 . The mosquitoes were very troublesome for the first time.

June I5. Left Fresh Creek. Continuing our course south, we passed High Cay and numerous smaller cays, finally reaching Bearing Point (called Salvador Point on the charts) at the entrance to the Northern Bight about five in the evening. Here the ridge seemed very high, apparently the highest land on the island.

June I6. The next morning walked to a high point from which a good view was obtained. It was about seventy or eighty feet high, and one could look westward across the bight to the horizon, where a few cays could be seen. The bight is three or four, in some places five, miles from the northern shore to the cays that are scattered through it. One of the largest of these is Wood Cay. The coppet at Bearing Point has pines beyond it, and there are pines. on some of the cays in the bight. Going on board again, our next landing was at Cormorant Cay, a small cay, perhaps a hundred yards long by forty or fifty wide. Many cormorants were nesting here, and both old and young birds were numerous. Some of the latter were still in the nests, but the majority were able to walk. The little ones opened their mouths and darted at my finger. Later we entered what the men called Loggerhead Creek, one of the channels of the North Bight, and sailing through this to the west side, made north and reached Purser Point at evening. This point is near the southern side of what is called the Wide Opening, 
a shallow bay or estuary two or three miles wide. We reached the point about five o'clock. The sun was just setting back of the white chalky beach which was fringed with an unbroken line of palmettoes; here and there was a mangrove clump, and beyond, nothing but water and sky. A desolate scene with no sign of life anywhere.

Thursday, June I 7. Walked back from Purser Point. The whole shore deposit is much whiter than at Red Bays. In some places along shore the white mud has been washed by the ripples so as to resemble miniature cliffs. These were made very noticeable by the dense blue shadows. In places the water had washed out the foraminifera and left them here and there, in little masses along the water line. The deposit is very soft. I ran a pole into it nine feet at a distance of a mile and a half from shore, where, nevertheless, the water was only about eighteen inches deep. Birds were plentiful. We saw many flamingoes, some summer ducks, long-shanks, night-hawks, and herons. There were many ponds where the water was about a foot and a half deep. Returned to the boat and about three o'clock started up Wide Opening, proceeded about a mile. Spent the night in the rowboat. The mosquitoes innumerable.

Wednesday, June I8. Sailed up as far as possible, but we grounded opposite the narrow channel marked on one of the charts as the River Lees which connects Wide Opening with the large body of water known as Turner Sound. It was an unusually dry season, and to our disappointment we found it impossible to cross the bar at the mouth of the channel. Our supply of water was exhausted, so we were obliged to turn back and run down the coast again to what the men called Cabbage Creek, which seems from the chart to be the other entrance to Turner Sound. Anchored for the night about a mile and a half from shore.

Thursday, June I9. Aground again about a mile and a quarter from shore, took to the skiff, but were soon obliged to leave that also, and finally to drag the boat over the flats to the channel that runs out for about half a mile beyond the mouth of the creek. The creek itself is about half a milewide at first, but soon narrows to about seventy-five yards, which width it retains for a long distance. The water in the center is about ten feet deep and the sides so steep that it is difficult to "set" up it. The shores are fringed with mangroves and palms. The creek is very winding, and the palms always grow on the outside curve, 


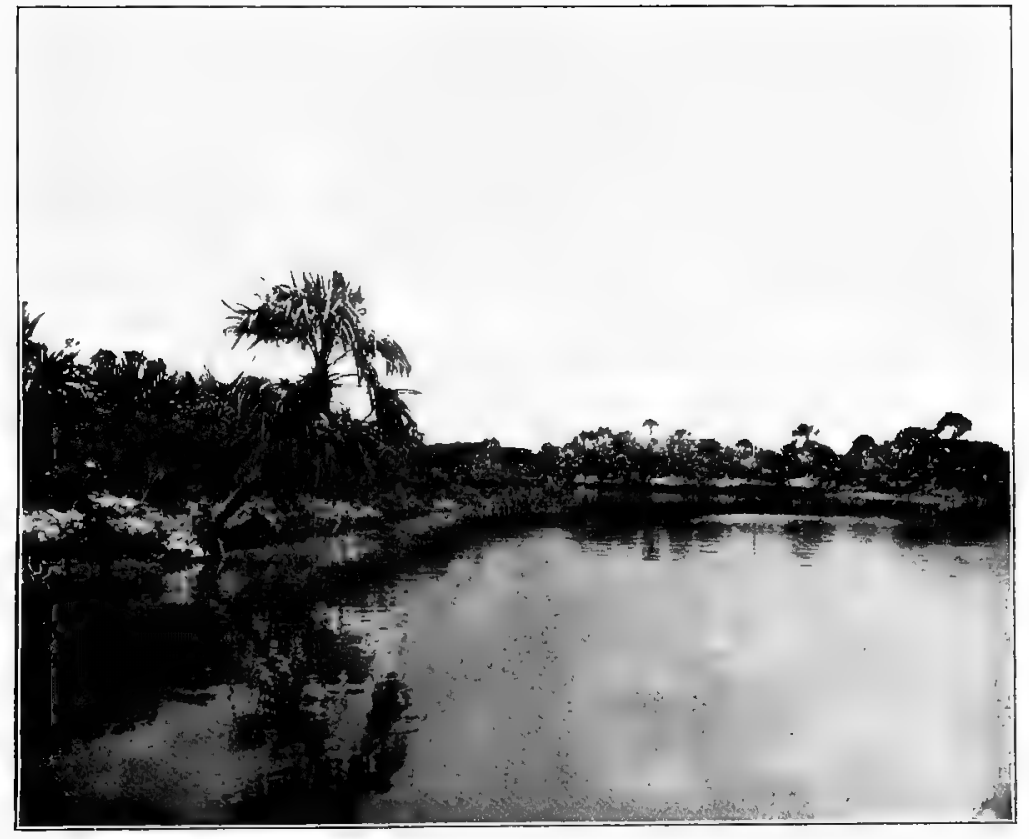

Cabbage Creek. 

the mangroves on the inside. We went up four or five miles to where the creek narrowed at the beginning of a large salt-water sound. Here the tide overflowed the land, and we found the same white deposit as on the shore. Redwing blackbirds and willets are common on the swashes. Got out of the creek in the afternoon, and with a southwest wind, started back for Loggerhead Creek. On the way passed a sponging schooner of less than twenty tons, with eight boats in tow. Two men to a boat and the cook made seventeen men at least on the vessel.

Friday, June 20. Loggerhead Creek. In the morning the men coming on shore with sponges for the crawls passed us, some of the boats sculled by small boys from seven to ten years of age. Later passed a sponge-crawl, built of stakes and resembling a weir. The sponges are soaked in these inclosures for about five days, and are then cleaned by holding them in the left hand and beating them with a stick. They are then left on shore until ready to be taken home. About noon the sky darkened to the north, and rain fell in torrents for about an hour. We took the passage known as the Middle Bight, passing many cays covered with palmettoes or with pines.

Saturday, June 2I. Continued beating through Middle Bight, finally reached our destination, Mangrove Cay, towards evening. This is one of the largest settlements on the island, and it is here that the magistrate of the island lives. Both he and Mr. Mathews, the representative of the Episcopal Church on Andros, are white men. Spent the night with Mr. Mathews. The next day walked back a short distance. There are many small hills, the surface is rough, and there are numerous banana holes.

June 23. Walked to Lisbon Creek, about four miles south of the settlement. The creek forms the southern boundary of the Cay. The road ran along the beach towards a long point. Near the head of the point was a deep hole close to the shore in which Mr. Mathews said the water was twelve or sixteen fathoms deep. The diameter of the hole was perhaps a hundred feet. We crossed the point and walked along the southern shore to a house at the mouth of the creek, where we planned to stay several days. The coppet about here is largely logwood (Hcematoxylon campechianum). It is said that when once planted this will soon drive out all the native trees. Thermometer 86 in the shade. 
Tuesday, June 24. Up at sunrise. Sailed up Lisbon Creek. Not far above its mouth it widens and is no longer a creek, but a large lakelike body of water, shallow and containing a number of large cays covered with pines. On these large cays are quite a number of iguanas. We saw several; they run with almost incredible swiftness. Got two small ones. They are said to occasionally attain a length of five or six feet. The negroes hunt them with dogs which drive them in holes, when they are easily caught. We were told they were formerly much more abundant.

Wednesday, June 25. Walked back to "high coppet." The land was high and contained many banana holes. The trees were larger and taller than in the surrounding region. The largest was a "horse-flesh" that measured five and a half feet in circumference, four feet from the ground.

Thursday, June 26. Left Lisbon Creek, continuing our trip south, stopped a short time at Kemp Sound. Saw a small gray owl and found some new plants. Shore bordered with cocoanuts and houses for a long distance, the high coppet behind them. No pines to be seen. Slept in the rowboat.

Friday, June 27. Sailed to Henry Dames, a short distance below Deep Creek. There are five houses here, surrounded with cocoanutpalms. We found Mr. Dames hospitable and intelligent. He gave us considerable information as to medicinal plants and the commercial value of the different kinds of wood.

Saturday, June 28. Walked back into the coppet about four miles over the "road" made by the surveyors. No pines in sight. The ground was high and very rough, and banana-holes were numerous. The place is known as the "high coppet," and the trees are the largest we have seen on the island. Horse-flesh (Lysiloma) and Madeira (Swietenia mahogani), between two and three feet in diameter, were common, and a number of "nakedwood" trees (Myrtus punctatus) were over a foot through. We found many new plants. Iguanas are said to be plentiful farther back and to sell for sixpence a pound. The negroes consider them a great delicacy. The rare blue thrasher and the white-headed pigeon were abundant about here.

Sunday, June 29. Left Dames at six o'clock. Continued on our way south. Beat against adverse winds all day, only got within two or three miles of Grassy Creek. Scenery along shore much the same as farther north, except the trees were slightly lower. 


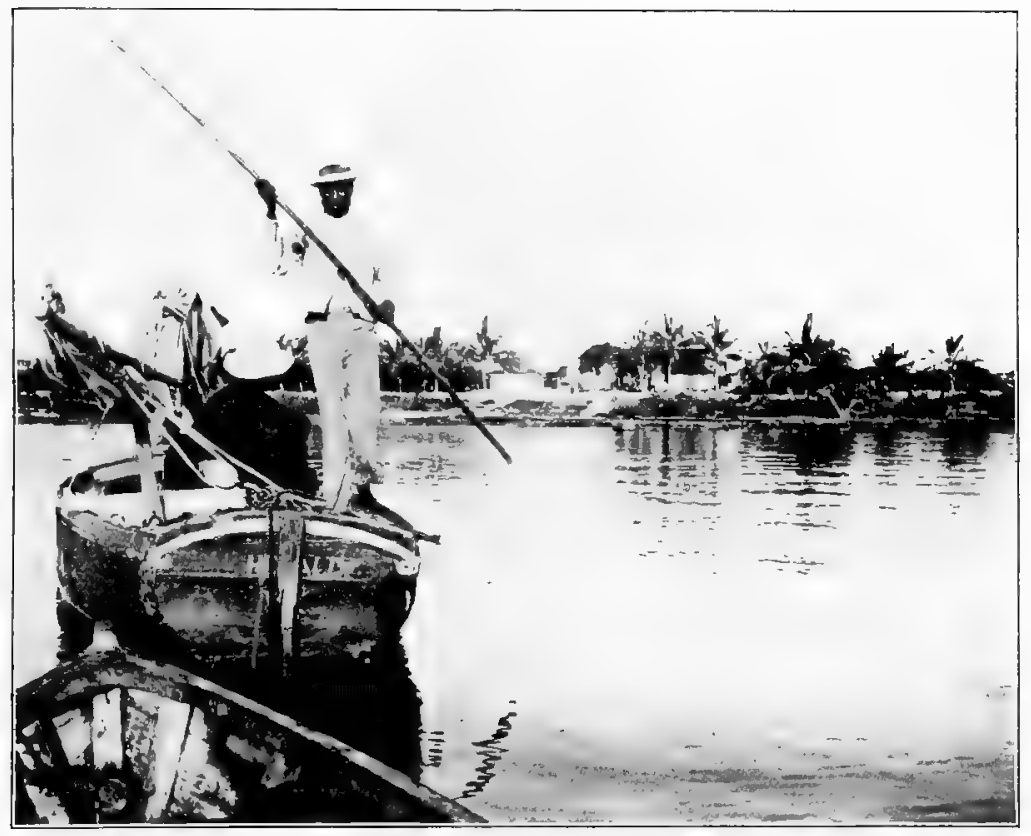

Coming to Anchor off the Dames' Place. 

Monday, June 3o. Sailed to Grassy Creek, which is within a few miles of the southern end of the island. The creek is about seventyfive yards in width. The men said that the swash began only a short distance back. There was a party of turtlers on shore cutting up live hawksbill turtles. A storm threatening, we did not sail up the creek any great distance, but turned back for Smith's place. Thunderstorm very heavy, but we were not in the worst of it. The sky to the north was very black; saw a water-spout in that direction, the column slanted to the westward. There was a dead nurse-shark on the shore, found it to be 7 feet II inches in length, steel color below, darker above. Near Smith's house was the largest ocean-hole I have seen. Smith says he has found no bottom with a twenty-fathom rope. Surrounding it, there is at low water nearly three-quarters of a mile of sand flat, the water being only about two feet deep at that distance from the shore.

Tuesday, July I. Walked back over surveyor's line. The trees and bush had been cut down and left where they fell. The ground very rough with large banana-holes. The swash was seen only a half mile back so that the coppet is here much narrower than at Deep Creek. Back to boat and waited until four o'clock for the tide to rise. Reached Dames that night, just below Deep Creek. Arrived at Lisbon Creek the evening of July 2.

Thursday, July 3. Packed and put specimens on schooner for Nassau. We started about midnight, slept on deck. Very slight dew. Reached Nassau evening of July 4, having been becalmed much of the day. A few days later we took the steamer for home.

It may not be amiss to say something here of the inhabitants and interests of Andros Island as we found them in 1890 . All the settlements were on the eastern ridge, with the exception of the small one at Red Bays in the extreme northwest corner. The remainder of the western coast was practically uninhabited and was visited only by the spongers. The writer believes she enjoys the distinction of having been the first white woman to set foot on this part of the island. On the east coast Nicol's Town was the most northerly settlement, then came Mastic Point, Stanniard Creek, Fresh Creek, Bearing Point, at the entrance to the North Bight, then Mangrove Cay, Long Bay Cay, and Deep Creek. At the time of our visit Nicol's Town, Fresh Creek, and Mangrove Cay were the largest. All communication between the different settlements was by water, as there were no roads, the government road at 
Fresh Creek being the nearest approach to one. What the negroes termed roads were only the roughest kind of footpaths leading back to their fields. The ground was on the whole very much rougher than on New Providence, and walking was often extremely difficult.

The people all seemed to be very poor. The majority of the men were engaged in sponging, and the women in consequence did most of the work in the fields. Some few owned their land, but the majority cleared a piece of coppet and started a "field" wherever they fancied, often four or five miles back in the bush. They raised corn, cassava, sweet potatoes, bananas, and sometimes a few beans, pigeon-peas, yams, and tomatoes, usually only a few plants of each, set out at random. Their principal tool was the machete, with which they cut down the weeds and bushes and turned up what little soil there was in the cavities of the rock. A number of the gentlemen of Nassau had interests and plantations on the island. There were extensive cocoanut groves near Lowe Sound and Nicol's Town; sisal plantations at Conch Sound, and at Kemp Sound just above Deep Creek, and a large pineapple plantation near Long Bay Cay. These, with the two sponge warehouses, one at Nicol's Town and one near Mangrove Cay, comprised the business interests of the island.

At the time we were on Andros there were only seven white people on the island, and for weeks at a time we did not see a white face. We found the negroes, without exception, courteous, hospitable, and obliging. More than that, as far as we were concerned, we found them perfectly honest. We frequently left our house open and unguarded all day, yet not a single article was ever missed.

We heard that many changes took place shortly after we left. A large English company bought up a number of square miles and began the cultivation of sisal on an extensive scale. After a few years' trial it was found that the financial returns did not come up to the company's expectations, and the work has since been entirely abandoned.

\section{SUMMARY OF THE COLLECTIONS BROUGHT BACK}

\section{VERTEBRATES}

Mammals. - The only mammals on Andros were bats and rats. The bat was Macrotus waterhousei, kindly determined by Dr. J. A. Allen. The rat was Mus rattus. 
Birds. - Two hundred and eighty-six specimens, representing twenty-seven families and seventy-four species.

Reptiles. - Lizards, many specimens in alcohol. The collection was sent to Dr. Cope for determination, but unfortunately the list returned by him was lost. The following note is from one of his letters: "There is no new species, but the Spharodactylus spectator is brought from the Bahamas for the first time, to my knowledge." There were several iguana skins in the collection.

Snakes. - A number of specimens in alcohol, representing about eleven species. The largest was a species of boa-constrictor.

Fishes. - About twelve species represented.

\section{INVERTEBRATES}

Mollusks. - Four or five hundred specimens, representing one hundred and nine species. See list of shells named by Dr. Dall. There were also four or five Ascidians and Cephalopods.

Crustaceans. - About 375 specimens, representing sixty-seven species. See report by Dr. Rankin.

A number of centipedes, spiders, beetles, moths, and butterflies were also collected.

Annelides. - Numerous specimens.

Echinoderms include, in addition to the starfishes (a list of which appear below), many specimens of holothurians and sea-urchins.

Colenterates. - Numerous corals, including a number of alcyonoid corals.

Actinia. - Fourteen species. See report by Professor McMurrich. There were also a number of hydroids and several medusæ. Of one of the latter which was sent to Dr. J. Walter Fewkes he wrote "the large black specimen I take to be a Linerges. The color is brown yellow in nature. Linerges mercurius Haeckel is figured in my Acalypha from Key West and Tortugas."

There was also a set of Bahaman sponges.

Plants. - About seven thousand specimens, representing five hundred and seventy species. See report on Flora of New Providence and Andros.

A collection of woods.

Various geological specimens, including fossils, specimens illustrating erosion, and samples of soil from various places.

With much of the material were full notes, for it was my husband's hope to embody the results of the trip in a volume which would be a contribution to the physical history, fauna, and flora of the Bahamas. The following pages show all that it has been possible to do towards fulfilling this plan. The greater part of the zoölogical material Dr. Northrop expected to work up himself. After his death, Professor Rankin kindly consented to determine the crustaceans and Professor McMurrich to complete the work on the Actinia. It has unfortunately been found impossible to have the rest of the collection worked up. It was stored for several years, owing to the removal of the University, and many labels were lost and misplaced. 
The entire collection is at Columbia with the exception of some of the duplicates. A set of the plants is in the University Herbarium in Bronx Park.

\section{LIST OF STARFISHES ${ }^{1}$}

\section{Determaned by JoHn I. Northrop}

Linckia Guildingii Gr. Collected at iNassau and also on Andros. Echinaster lentus? Nassau.

Ophiocoma echinata Ag. Common in pools and under stones at low water.

Ophiocoma pumila Lütken. Nassau. Twenty-one specimens. In one the upper arm-spines are flattened vertically, and the tip is indented or sometimes toothed. A few spines are much broader at base and prolonged backward in a point over the upper arm-plates, making them appear arrow-shaped.

Ophiocoma Riisei Lütken. One specimen from near Nassau.

Ophiura brevicauda Lyman. One specimen from near Nassau, under stones.

Ophiura cinerea Lyman. Nassau. The seventh joint of arm has ten spines instead of eight.

Ophiura appressa Say. Nassau. Four specimens.

Ophiomyxa flaccida Lütken. Nassau. Single specimen from near Quarantine Station.

Ophiothrix Erstedii Lütken. One specimen. Lyman states that this is the most abundant species of Florida and the West Indies. It did not seem to be at all common in the Bahamas. Ophiothrix Suensonii Lütken? Five specimens found on sponges in the sea-garden near Nassau, seem to have but three or four spines.

1 Owing to their incompleteness the critical notes have been omitted. 


\title{
NOTES ON THE GEOLOGY OF THE BAHAMAS ${ }^{1}$
}

\author{
JOHN I. NORTHROP
}

(Abstract)

By far the greater number of the islands known as the Bahamas are situated on the Great and the Little Bahama Banks. The former occupies a large area southeast of Florida and north of Cuba, and is penetrated in the northern part in a remarkable manner by a tongue of the ocean in which the water is over seven hundred fathoms in depth. Little Bahama Bank lies north of the Great one and is much smaller.

The islands lie, almost without exception, on the northern and eastern edges of the banks, the main exception being the island of Great Bahama, which is situated on the southern edge of Little Bahama Bank. Southeast of the Great Bank is a small one, on which are Crooked and Acklin islands, the former on the northern, the latter on the eastern edge.

The Caicos Bank lies still farther southeast and contains on its northern border a number of small islands. The rest of the group viz. the islands of San Salvador, Rum Cay, Atwood's Cay, Mariguana, and Little and Great Inagua - are differently situated from those previously mentioned, rising almost abruptly from the deep ocean.

The time spent in the Bahamas was a little more than six months, two of which were passed in New Providence and the rest in Andros. The former is well known as the seat of government and as a health resort. It lies on the northern edge of a portion of the Great Bahama Bank, and is about twenty miles long and seven in width. A ridge runs along the northern side, the highest point of which is 109 feet above sea-level, and is occupied by an old fort-Fort Fincastle. Here a fine view of the general features of the island may be obtained. To the south stretches a low level country dotted here and there with

${ }^{1}$ Trans. N. Y. Acad. Sciences, October 13, I89o, pp. 4-22. 
cocoanut groves, and in the distance is seen a lower ridge, known as the Blue Hills. To the north we look over the harbor, half a mile in width, to Hog Island, a cay about four miles long, perhaps half a mile wide, and about twenty feet high. The eastern end is separated by a narrow piece of water, known as the "Sea Garden," from Athol or Long Island, locally known as Quarantine Station, a cay about two miles long and but a quarter mile wide, and continued eastward by narrow shoals. West of Hog Island is the channel, or, as it is called, "the bar," on the other side of which a number of small cays continue the same general direction as the longer axis of the island. Seaward of Hog Island, and separated from it by about one mile of water, is Salt Cay, an island about two miles in length and a quarter in width. Farther to the north and outside of Quarantine Station is Rose Island, another long narrow cay. Outside of all lies the reef. These facts have been given with perhaps more detail than is interesting, but which, nevertheless, is necessary, as it has a bearing upon what follows.

Andros Island is the largest of the Bahama group, being over ninety miles long and between forty and fifty miles wide. The northern portion is separated from the southern by a broad shallow sheet of water that contains many cays, large and small, and the passages through from the eastern to the western coast are known as bights. It is interesting to note that Andros is not only the largest of the Bahama islands, but the largest coral island in the world, its northern half alone having a superficial area of over I200 square miles, while the area of the whole island, so called, is over xgoo. It lies near the eastern edge of the bank that faces the tongue of ocean referred to ábove.

The eastern side of Andros is occupied by a ridge, of which the highest point that I visited, and I think the highest on the island, is marked on the chart as Salvador Point, locally known as Bearing Point. Its height I had no means of determining, but I judged it to be about roo feet. At the extreme southern end, as at Grassy Creek, this ridge is absent and the land is low.

When one has crossed the ridge, which is covered with angiospermous trees, he enters a large forest of Pinus bahamensis which occupies the greater portion of the interior of the island. The land is here almost level, and in some places, as near Loggerhead Creek and Wide Opening, there are extensive lakes of fresh water. Upon passing 
through the pines and reaching the west side, one comes to the most remarkable feature of the island. Here one sees spread out before him, as far as the eye can reach, a low swampy country covered with small mangroves; Conocarpus and Avicennia, bounded on one side by the water, and sometimes, in the distance, by a dark line of pines. The pines, however, frequently jut out in points that approach quite close to the water's edge. This level swampy land is locally known by the very appropriate name of "swash." To the west of the land stretches the Great Bahama Bank for a distance of from fifty to seventy miles, and the slope of the bottom is so exceedingly slight that at the distance of seventy miles from shore the water is but three or four fathoms deep. The bank then plunges suddenly into the ocean beyond.

There are many creeks on the island, and the water in all, at a distance of ten or fifteen miles from the mouth, is drinkable. Many little streams of fresh water flow into these creeks, thus partially draining the immense area of swash.

The creeks are generally narrow and winding, and by wearing away the land on the convex side of the curves change the character of the surface of the country. This was most plainly seen up Cabbage Creek, near Wide Opening, on the west side. Here, as the creek wore its way into the land, it was followed on the concave side by a growth of small mangroves, while its convex side was fringed with palmettoes. As the creek, in winding, changed its course, the palmettoes and mangroves changed sides, as it were, the former always on the outside of the curve, thus making quite a striking alteration in the appearance of the landscape.

The surface on the western side of Andros is composed of an exceedingly fine, almost impalpable, calcareous coral "mud," that also forms the bottom of the shallow water that covers the bank. As w'e go back from the water's edge this deposit becomes harder and harder, until finally it is cemented into a hard, very fine-grained rock that is very different in appearance from the rock of the eastern coast. The latter is Æolian and varies in texture. In some places it is quite coarse and in others finé, but always composed of rounded grains of coral sand or comminuted shells. In some places, as at Conch Rock, near Conch Sound, the rock has been so altered as to resemble a dark gray crystalline limestone. In one place only did I see the contact between 
the Æolian formation and the true coral rock. This was on Andros near the entrance to Fresh Creek, where a vertical face about ten feet in height was exposed. The lower four feet were composed of fragments of coral stems, mostly a madrepore, probably Madreporus cervicornus, but so eroded as to make identification impossible. Above this lay the Eolian rock, the contact being sharp and distinct, and the contrast between the laminated appearance of the one and the irregular surface of the other being very striking. While no masses of corals were to be seen, that were undoubtedly standing as they grew, the fragments, some of them about a foot in length, were crowded together and presented the same appearance as I had seen in places in the reef at Nicol's Town, where the branches of $M$. cervicornus had been broken off and lay in a heap on the bottom. The striking contrast between the $Æ$ lian rock above and that in which the corals were showed plainly that the two rocks were formed under different circumstances, and that the lower stratum had been formed under water, for it showed none of the characteristics of beach or wind-drifted deposits. Although this is the only place where.elevated corals were found in profusion, in many other localities, as at Nicol's Town and Mastic Point, Andros, a few fossil corals were found embedded in the rock and evidently in place. The most common coral thus found was a Mæandrina, probably the same as that now living on the shore near low-water mark - a circular, flat species.

In Nassau excellent sections of the rock can be seen in an old quarry, the "Queen's Staircase," and in the present quarry. In the first of these places the section is, I believe, ninety feet high, and the rock is entirely Æolian. The most common fossil is a species of Strophia that I suspect will prove different from those now living on the island. ${ }^{1}$ A few helicoid shells were collected, and parts of a crab were noted, but only one or two marine shells, a Fissurella, and fragments of a lamellibranch were obtained. These facts all indicate the Æolian origin of the deposit.

${ }^{1}$ My thanks are due to Professor Dall, who has kindly examined my Strophias, and who is inclined to provisionally refer some of the fossil forms to $S$. maritima Pfr, $_{\text {, }}$ and states that others seem to connect maritima with forms like Glans Kust., which I found living on Andros. 


\section{Surface Deposits}

There is practically no soil either on New Providence or Andros, except the little that collects in the caves and holes in the rock. From the caves a large quantity of cave earth has been taken and sold as a fertilizer, with what result I do not know. I was told that guano had been found on Andros, but I saw none. The earths I collected I have treated with hydrochloric acid, and the results indicate a great variation in composition. In some, most of the material is soluble with strong effervescence, but in others the residual, I suspect, will prove greater than the soluble portion. The residue seems to be composed of organic material, with some mineral constituents that contain an appreciable quantity of iron. Dr. Waller, of the School of Mines, Columbia College, has kindly offered to analyze my material, and we hope from the results to draw some conclusions as to its origin. At present it seems as if the earthy deposits are composed of the insoluble portions of the coral rock mixed with vegetable particles.

The absence of any large quantity of fallen leaves is very noticeable. In the "Pine-yard," as the pine woods are locally called, we did not see a single fallen pine, but the depressions in the ground showed where one had formerly stood, and a long shallow trough plainly indicated where the fallen trunk had lain. Desiccation and decay take place with astonishing rapidity, and I believe that the deposits found in the caves are greatly added to by the comminuted particles of dried vegetable matter, and the residue of the decomposed portions, both of which would be washed in by rain-water.

On the "swash" on the west coast of Andros a peculiar ash-like deposit was noticed that covered small circular areas. This, on examination, proved to be composed of soft elastic lumps coated with calcareous material. These lumps under the microscope were seen to be composed of one of the small, probably fresh-water, algæ that had grown in the pools of water, and which had been left when the pools had dried.

\section{EROSION}

One of the most striking geological changes taking place in the Bahamas is the erosion of both the surface and the shore line of the islands. 


\section{NOTES ON THE GEOLOGY OF THE BAHAMAS}

West of Nassau, on the beach, are many places where the waves have cut narrow passages into the rocks and ground the fragments into sand. There are also a number of "pot-holes"; these were circular in horizontal sections, and the bottom and sides were smooth. They contained the worm coral heads that had evidently been the means of making the holes.

On the beach of the cays north of Nassau great blocks of coral rock are seen that have been dislodged by the waves, and in some places fresh fractures show where large fragments have been broken off. On the south side of the cays the erosion is different. Here the water is quiet and eats slowly under the rock, so that a projecting ledge is formed that marks the height of the tide.

At some places on Andros, as at Fresh Creek and Nicol's Town, the shore is undermined, and great slabs in places have fallen, thus making large cracks. Similar cracks are found inland higher above high-water mark, and have evidently been formed in the same manner as those on the shore. Where the edges of the crack were in contact they had been firmly cemented together, and at intervals along the line of the crack were numerous large holes that had evidently been worn out by the action of rain-water running over the edge. Leading into these holes were channels almost as perfectly formed and rounded as a tin gutter.

The erosion of the surface will impress every one that visits the Bahamas. Sharp jagged points project so as to make walking tiresome and annoying. Although there is some sand near the beach west of the Barracks at Nassau, there are no great moving masses such as Heilprin describes as being found in Bermuda. ${ }^{1}$

In some places, as on Goat Cay, near Fresh Creek, Andros, the surface is eroded in a peculiar and striking manner. There the rock is worn so as to leave vertical cylindrical masses two or three feet high, some connected below or halfway up with each other, others separate. Their sides and tops are pitted and eroded, so they have evidently been affected by atmospheric agencies. On the ocean side of this cay the erosion from the action of the surf was so exceedingly rapid that the rock remained a light yellowish color instead of the dull or dark gray it commonly assumes. The form the rock here presented was even more striking than the cylindrical masses described above. It was 


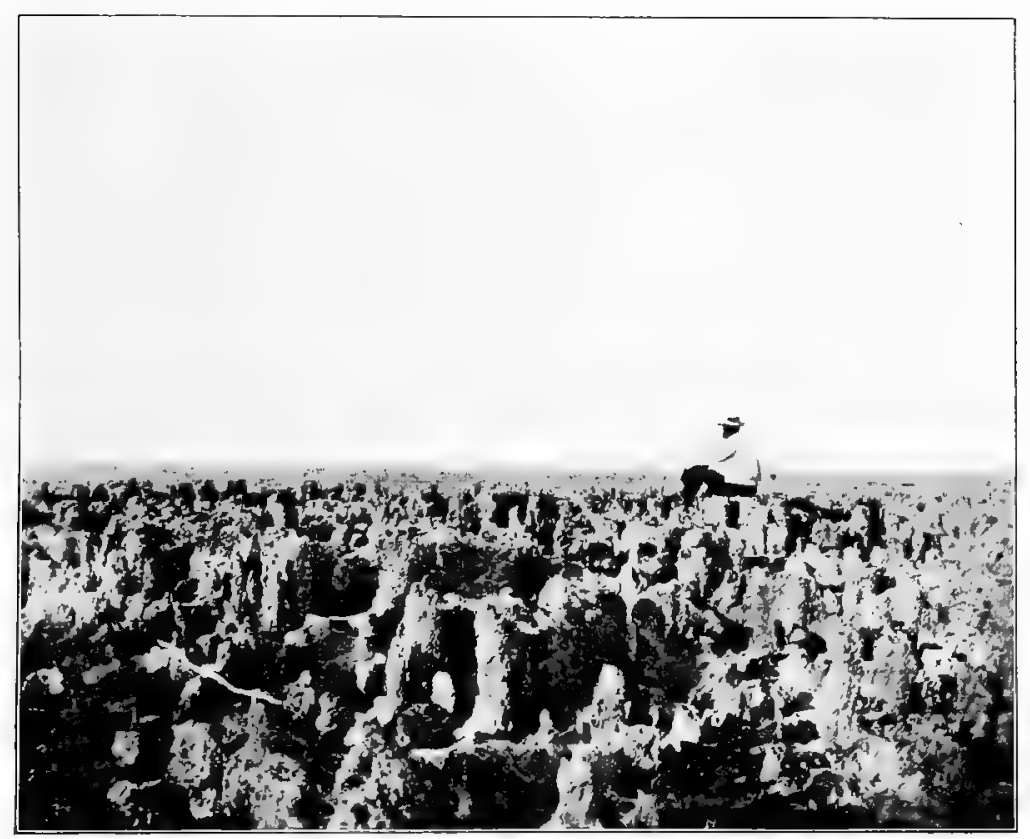

Goat Cay, Andros. 

worn into innumerable peaks and pinnacles like a miniature mountain range, the points and edges of the pyramidal projections being sharp and clean. As we walked back from the edge of the cay, every gradation could be found between the miniature peaks and the cylindrical masses higher up. And I believe that the latter are what remains after the edges of the little peaks and pyramids have been slowly worn away by the action of atmospheric agencies; for we have only to round off the points and deepen the connecting ridges to produce the vertical cylindrical masses. But in order that this could have occurred, it will be necessary to suppose that the island has been elevated, and this, as I hope to show, I believe has been the case.

\section{OUTLIERS}

In many places near Andros, as at Mastic Point and Golden Cay, there are cays separated from the island by water but a few feet in depth, and in some places these cays make a prolongation of a point with which I believe they were formerly connected, and have been cut off, not by subsidence, but by erosion. There are other cays, as those near Nassau, that, as I hope to be able to show, owe their origin to another source.

\section{Caves}

One of "the sights" at Nassau are "The Caves," about seven miles west of the city. One of these is an irregular opening in the north side of a hill that faces the sea. The floor is considerably above highwater mark. In the back of the first chamber is a small opening through which can be seen a deeper chamber, in the bottom of which is water. This chamber is said to connect with the cave on the opposite side of the same hill. This second cave is a long chamber about fifteen or twenty feet in height, and the roof contains holes through which the roots of trees pass and fasten into the floor below. The side wall of the cave for a distance of about four feet from the ground projected about six inches beyond the upper part of the wall, thus forming a shelf that was quite level and ran the entire length of the chamber, a distance of perhaps one hundred feet. I could only explain the formation of this shelf by supposing that it represented the contact between two deposits, and that the upper had yielded more rapidly than the lower to erosion. 


\section{NOTES ON THE GEOLOGY OF THE BAHAMAS}

On Andros I saw a number of caves near the northern part of the island. All were in the sides of the elevated portions. The openings in some, as one near Nicol's Town, were small, barely as large as an ordinary door. Others were simply excavations in the side of the hills.

In some places, as near Nicol's Town and Mastic Point, small caves were found, twenty to forty feet above high-water mark; and the low vertical cliffs in which they were, indicated the existence of an old shore line, for the rocks were undermined in the same manner as those we now see on the present shore.

In some of these caves Indian relics have been found, and also human bones, and I obtained a portion of a human humerus from one on Andros.

\section{OCEAN Holes}

Near the caves at Nicol's Town was a hole known as the "Ocean Hole." It was about one hundred feet in diameter and perhaps forty feet in depth, and contained a pool of brackish water. In one place the wall had been excavated so as to form a small cave, while the rest was quite steep and covered with trees and large blocks of coral rock. In one place was a very marked unconformability in the rock, the seeming strata below lying at an angle of about 30 degrees, while above the layers were horizontal. This was probably only an unusual arrangement of the Æolian formation; but in the Queen's Staircase, where an unusually fine section is exposed, the layers lie at different angles, but are wedged in between each other, as it were, and no such sharp unconformability as that above described is to be seen.

The name "ocean hole" is also applied by the natives of Andros to deep holes under the water. Some of these are remarkable. The first that I saw was near Mangrove Cay. Here, close to the shore, was a nearly circular hole at least Ioo feet in diameter, and in which the water was said to be over I 8 fathoms (IO4 feet) in depth. I did not have an opportunity of sounding it, but the dark blue color of the water told its own story.

While sailing up Fresh Creek, Andros, we came to another ocean hole, which I examined. It was about ten miles from the mouth of the creek, close to the northern bank, and about one hundred feet in diameter. From the shore the water for a distance of about fifteen feet 


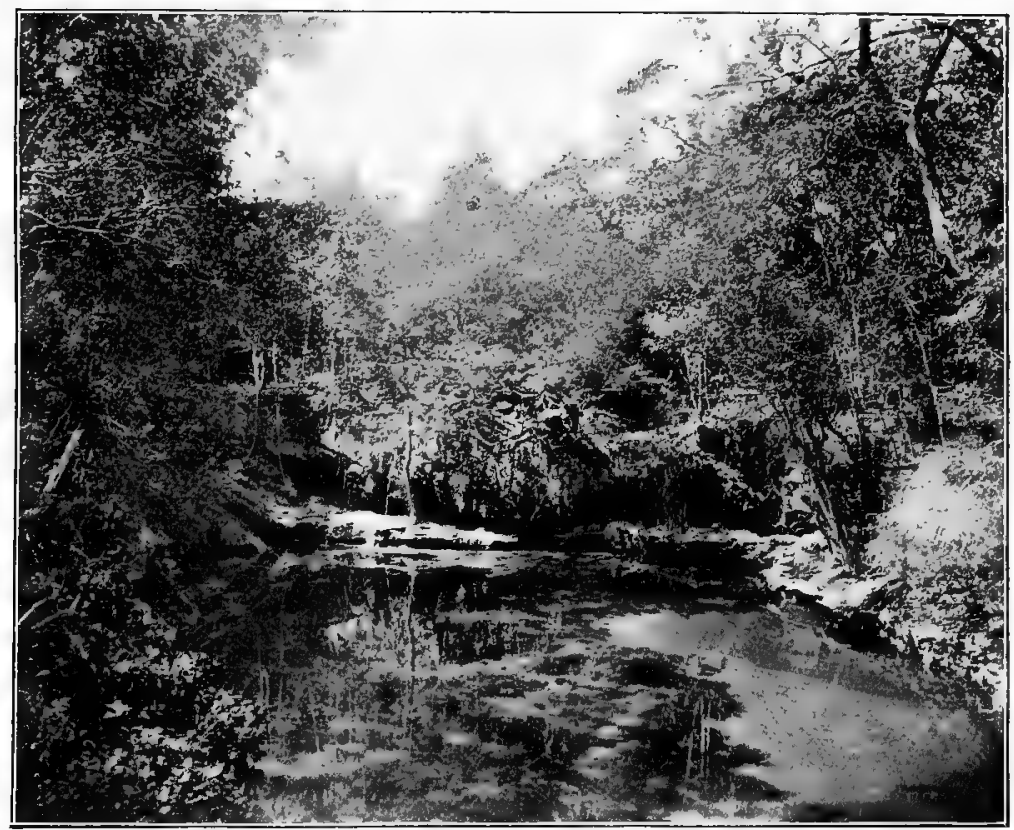

Ocean Hole, Nicol's Town. 

was two feet in depth, and then suddenly deepened to eighteen feet over a projecting ledge. Sounding across the hole did not show a greater depth. The bottom of the hole was of soft coral mud. The bottom of the creek surrounding the hole was covered with about two feet of water, and in some places gradually sloped into the hole. Still farther up the creek another hole was seen, but was not examined. The most remarkable ocean hole that I saw was one near Grassy Creek, near the southern end of the east side of Andros. The diameter was about one hundred and fifty feet, and the shore itself formed one edge of the hole. The sides were of sand at its angle of repose for a depth of about six or seven feet below, and resting on an overhanging ledge of rock. Where the tide had fallen it left the hole surrounded by at least a quarter mile of sand flat on the ocean side, while, as stated above, the shore formed the rest of the boundary. This hole I sounded with all the line I possessed, but at twenty fathoms the weight was cut off, and I was unable to obtain another to continue the sounding. The captain of our boat, a reliable man, told me that in the "Pine-yard" was a hole similar to this one, in which he had found no bottom with a line over thirty fathoms in length. Before attempting to explain the formation of these ocean holes it will be well to describe what the natives call

\section{BOILING HoLES}

The first of these I was shown on Andros in a small creek that runs into Conch Sound. The top of the hole was about a foot under water at low tide, and close to the mangroves that formed the side of the creek. It was about seven feet in length and about two or three wide. Below the diameter increased, forming an overhanging ledge. When the tide was low in the creek, but rising outside, the clear sea-water could be distinctly seen ascending, thus producing the same appearance as that presented by a mixture of sulphuric acid and water. Suspended particles could also be seen rising.

While sailing past Rat Cay, near Mastic Point, another "boiling hole" was seen that was apparently about ten feet in diameter, and from a distance we could see a perceptible "boil" on the surface that was undoubtedly caused by the rising water. Our captain said that when the tide was falling, the water in the hole went "down and round" - which statement I believe, as the water was rising with some 
force, and probably ran out again with sufficient rapidity to cause a small whirlpool. In another boiling hole near Mangrove Cay the water was seen ascending.

These facts prove not only that an underground connection exists between these holes and the ocean, but that the connection is an open one, so that the water can flow freely through it, and thus the pressure resulting from the passing tidal wave is shown before the tide commences to rise on the shore. The ocean holes, I believe, can be explained by supposing them to be old boiling holes in which the connection has been stopped up, and their greater size caused by the falling-in of the ledge on the edge, which would aid in the stoppage. I regret that I have no facts to offer on the depth of the boiling holes, for the only one I stopped to examine was at Conch Sound, and this one ran under the ledge, so that its depth could not be determined. The ocean hole at Nicols Town, described above, is also, I believe, an old ocean hole now elevated.

\section{Banana Holes}

These are holes found mainly on the elevated parts of the land on both New Providence and Andros. They contain a quantity of earth in the bottom, in which the natives plant their bananas, hence the name.

In shape and dimensions these holes vary greatly. Some are cylindrical, about four feet in diameter, but at the same time twenty feet or more in depth. Others are from ten to twenty-five feet across, and some even larger, and often of an irregular shape and much longer than wide.

The walls are often excavated below, so that the side becomes an overhanging ledge and forms a small cave. In some a cave begins at the side of the hole and runs backward. It is hence hard to draw the line between these holes and the caves. There are also holes that are not called banana holes, but which may be here described, as they differ only in shape. In some the opening is barely large enough to allow a man to pass. One such I descended, and found that below it was over five feet in diameter and cylindrical. The top had been excavated so as to form a domed roof.

Other holes were connected by a horizontal passage through which I could crawl from one to the other. One of these I saw near Conch 
Sound, where the passage ran from the bottom of one hole to the side of the other, which was much deeper.

Near by I saw two shallow holes that were connected by a horizontal passage, so that they resembled a large tube bent up at each end. It is not unusual to find openings in the ground, barely large enough to admit an ordinary pail, and sometimes much smaller. These are simply openings in the roof of a cave or hole of unknown dimensions, and frequently in the bottom is a quantity of fresh water that is used by the people.

The subject of banana holes has been briefly discussed by Dr. C. S. Dolley, ${ }^{1}$ who accounts for their formation by "the action of decaying vegetable matter, that undergoes fermentative changes by the products of which the soft calcareous rock is dissolved and leaches away." There is no doubt that the rock is in many places eroded in this manner, as the small saucer-shaped depressions so common on the surface, and each often containing leaves and water, plainly testify. But I doubt if this agent alone would cause the deep vertical cylindrical holes, or those in which the sides recede into caves or the horizontal passages. And if the holes were formed in the manner described by Dr. Dolley, should we not find them in the low-level land as well as on the ridges? But, as stated before, the holes are found in far greater number on the ridges, and in places where the surface is such as to indicate that formerly the erosion from the waves was very great. If we could have a good view of the proper bottom of a banana hole, we might be able to account for their formation; but, unfortunately, the bottom is always filled with a deposit gf earth or blocks of coral rock, and generally covered with vegetation."

It is not improbable that the deep cylindrical ones were formed in the same manner as pot-holes. And others might have originated in the same way as the spouting holes, where the waves undermine the shore and afterward break an opening in the rock above. Should some of the boiling holes, described above, become elevated and their bottoms filled up with fallen blocks of coral rock and deposits of earth, they would form banana holes. The holes in the cracks at Fresh Creek can be easily explained, but if all banana holes were formed in this manner, we should find them in a line with others, which I was told was the case, but I was never able to satisfy myself that it was so. The

\footnotetext{
1 Proc. Acad. Nat. Sci. Philadelphia, I889, p. I32.
} 
caves are often the result of the former action of the sea, and some of them have probably been washed out by rain-water; but in either case, should a portion of the roof fall in, it would make a banana hole if small, or, if large, an ocean hole like the one near Nicol's Town. The horizontal passages are evidently washed out by water, but whether by the sea or rain-water, I do not know, but I believe either might have accomplished it. It is difficult to understand how underground channels could be formed under water, yet the boiling holes prove that such exist; but there is no means of determining whether they were formed under the present circumstances or at some previous period when the land might have been elevated.

I was told that holes were as common under the water as they were on the land, but did not myself observe this to be the case; but then my opportunities for observation in this direction were limited. I infer from the facts I have given that banana holes and caves pass gradually into each other, and that they have been formed by the action of the sea-water and afterwards modified by the action of rain-water, aided by the products of the decomposing vegetable material and in some cases by the falling-in of the roofs of the caves.

\section{Effects of Vegetation on the Surface}

One of the facts that I noticed shortly after my arrival in the Bahamas was the occurrence of great numbers of blocks of coral rock scattered irregularly over the ground, and I first thought that they were the result of the excessive erosion that I saw taking place around me. But on some of the cays - as on Goat Cay, described above - where the erosion was most rapid, there were no loose blocks, and if these had been formed by erosion alone, it was there that we should have found them most numerous.

I had often noticed the gnarled and stunted appearance of the bushes and trees that grew near the shore, and where there was evidently a severe struggle between the sea on the one hand and the plants on the other.

At Quarantine Station I was shown a small bush, Rhacicallis rupestris, and was told that it was over twenty-two years old, by a man who said he could remember the plant as "long as he could remember anything." I cut away the rock surrounding the bush, and found that 
its roots proceeded downward a few inches through the solid rock. At the surface the trunk expanded so as to form a projecting mass that rested on the rock: The bush was only about eighteen inches in height and evidently stunted by lack of nourishment. I then pulled up a number of shrubs in the vicinity, and found that their roots ran under the hard crust that formed the surface of the rock. "Further observation showed that in many places the crust had been lifted and broken by the growth of the roots, and then trees were noticed with the base of their trunks surrounded by slabs of rocks that leaned against them. Finally, when the rock becomes eroded, the roots of trees penetrate the holes and crevices, and by their growth crack off large fragments that subsequent erosion forms into boulders. And these boulders are found most abundant where the trees are the largest, and hence where the action of their roots is most vigorous. Hence we may infer that these blocks are formed by erosion and the growth of the roots of the shrubs and trees.

While at Nassau I noticed on the shore in some places - as near Dix Point - vertical masses of rock that ran in an irregularly curving or straight line on the surface. The projections were sometimes about one foot high and two to four inches in width, and containing on their upper edge a number of holes, about half an inch in diameter, that were often shallow and sometimes mere pits, but quite regularly distributed in a single line. These little ridges could sometimes be traced for a distance of fifteen or twenty feet, and had evidently been left standing while the surrounding rock had been eroded. For a long time I was unable to explain their formation. Sometimes the ridges intersected and formed small or large triangles, as the case might be. When I visited the south side of New Providence, I saw growing in the water, in the calcareous mud that there forms the bottom, the black mangrove or salt bush (Avicennia nitida), and radiating from it, projecting about five or six inches above the ground, were small vertical shoots about three or four inches apart and looking very much like the teeth of a very long wooden rake. These shoots, I afterward found, come from the long sucker-like roots of the Avicennia and also of the buttonwood (Conocarpus erectus). Later, on the west side of Andros, I found these plants growing near the water and also higher up on the beach, which here was a very fine calcareous deposit. This deposit had been slightly raised by the growth of the shoots, and higher up on the shore, 


\section{0

where in contact with the shoots, it had hardened into rock. This, I believe, explains the ridges described above, for the roots are frequently a foot below the surface, and the action of fresh water following down the shoots, and probably, also, the action of the juices of the plant, have slightly dissolved the calcareous material and then cemented it into a rock harder than the surrounding deposit. The latter, when erosion commences, wears away and leaves the harder ridge standing. The manner in which the ridges are formed, and the holes in the tops of them, all strengthen this conclusion. The triangular spaces enclosed by the ridges are almost identical in appearance with the triangular spaces marked off by the sucker-like roots that cross each other in all directions.

\section{RHIZOMORPHS}

While visiting the quarry at Nassau my attention was drawn to some cylindrical masses of coral rock that apparently hung root-like over the edges of the quarry and were about four feet in length. They were, however, cemented to the wall. I broke one off, and on examining it, found that the particles of which it was composed were arranged in a concentric manner about a central axis. On the way back from the quarry I pulled up a small shrub, and found its roots penetrating the rock, which had been eroded so as to leave cylinders surrounding them. Dr. Dolley ${ }^{1}$ has called attention to these cylindrical and tubular forms, and has explained their formation by supposing that they represent the "ramifications of a now exterminated flora," and also that "the juices of the roots, acting on the sand immediately surrounding them, formed a compact layer. Through erosion and subsidence the vegetation was afterward exterminated, the looser particles of drift rock worn away, and the surface left covered by myriads of tubes of all sizes, formerly occupied by plant roots and rootlets." Later, on Spruce Cay, near Nassau, and at many other places, I found a number of these cylindrical projections, some of which contained a small hole in the center, which in others was filled with calcareous material. I believe Dr. Dolley's theory of the formation of these cylindrical and tubular projections is, in the main, the correct one; for I collected specimens with the roots still in them, and the concentric arrangement

$$
{ }^{1} \text { Loc. cit., p. } 13 \text { r. }
$$




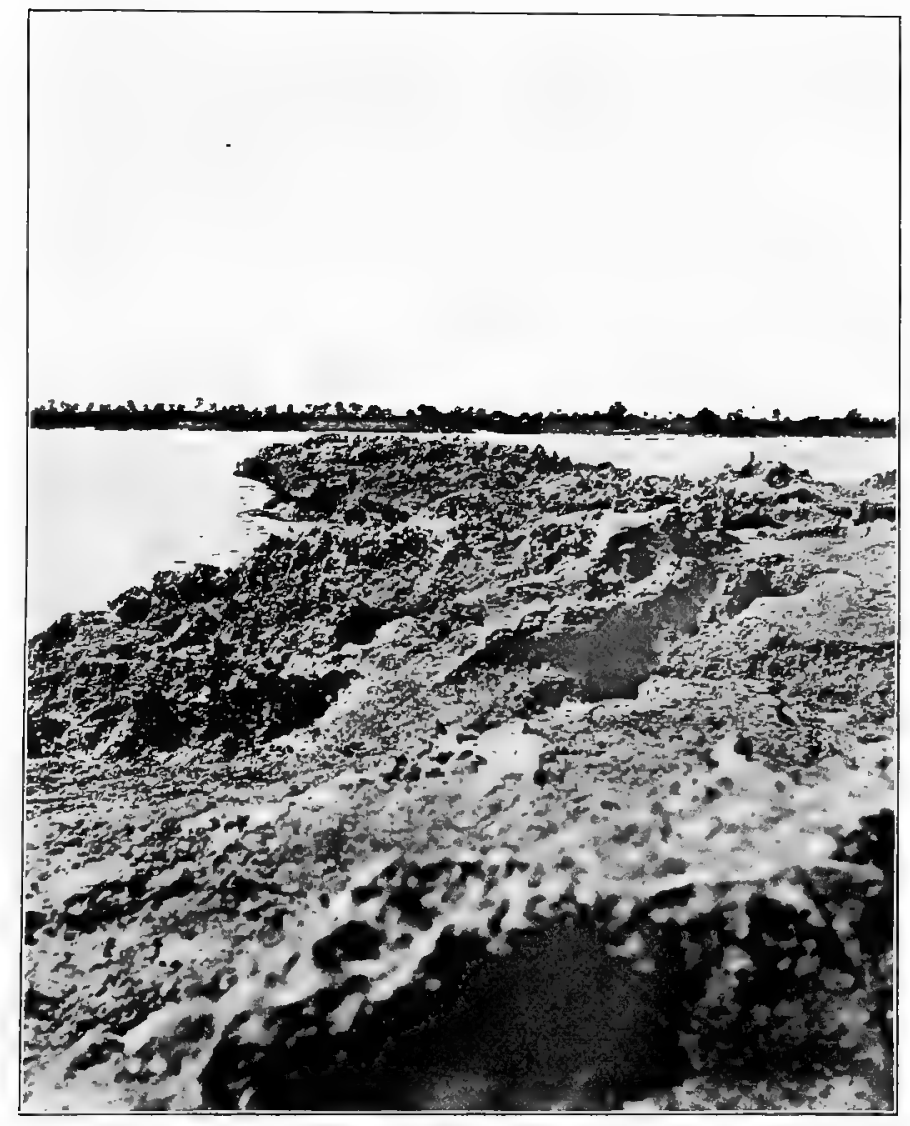

Spruce Cay, New Providence, showing Erosion. 

shown on cross section shows very plainly that the solvent action of the water, following the path of the root, had been from within outward. As these masses are conspicuous and characteristic, I would suggest that they be called rhizomorphs; and this name would also cover the tubular masses that have evidently been formed in the same manner, and which I have found in the ferruginous clays of New Jersey and elsewhere. The action of the water in the latter case has been on the iron contained in the clay.

Dr. Dolley is inclined to think that the rhizomorphs were formed while the sand was in a loose state; and while I do not deny that this might be possible, I believe that all that I saw had been formed by the roots penetrating the already hardened rock; and I furthermore found no rhizomorphs being formed by the plants growing in the loose sand.

Dr. Dolley also states" that the "small islands exhibiting these peculiar formations [rhizomorphs] are indications, therefore, of erosion and subsidence." I admit the erosion; but as the rhizomorphs are found twenty and thirty feet above the sea-level, I think that subsidence has taken no part in their formation.

These rhizomorphs are not to be confounded with the cylindrical masses described on Goat Cay, for the latter were vertical and did not exhibit the concentric arrangement of the particles so plainly shown in the rhizomorphs, which are found at all possible angles. And if we suppose the masses on Goat Cay to be due to the same process that formed the rhizomorphs, we must suppose that the roots that produced them grew vertically downward, which is extremely improbable. It may be well to state that a few rhizomorphs were found on Goat Cay, and the difference between them and the cylindrical masses was very marked.

It might be asked, if these rhizomorphs have been formed in the manner described, why is it that we do not find them everywhere on the islands? And in answer to this objection it may be said that roots of most of the trees spread out over the ground or slightly under the crust, but do not penetrate the rock; and that the roots of the smaller plants are those that have formed the rhizomorphs, and that these latter show only where there is but little vegetation, and where the erosion is active and not helped by the roots of trees breaking up the surface into blocks as described above.

\footnotetext{
${ }^{1}$ Loc. cit., p. I32.
} 


\section{Evidence of Subsidence and Elevation}

The facts bearing on the question of subsidence and elevation have already been given, but it may be worth while to briefly review them and give my inferences.

The caves and old beaches now above the sea plainly show where the level of the water formerly was. The section at Fresh Creek proves, as do the other cases of elevated corals, that the island has been elevated. As the formation on top of the corals at Fresh Creek is Eolian, it follows that it could have been deposited only above water; and as the caves and old beaches are at least thirty feet above the sealevel and in the Æolian formation, they could not have been formed until the islands had subsided. Hence we are justified in assuming that at some previous time in their history the islands were at about the same level as now. Then followed a period of subsidence of at least thirty feet, during which the caves and old shore-lines were formed. After this subsidence the islands were elevated to about their present position. It only remains to sum up the facts that bear on the question of the most recent movement in the Bahamas.

The fact that on the west coast of Andros, where the slope seaward is so exceedingly slight, the soft calcareous mud grows gradually harder and harder as we go inland, indicates to my mind that the island has been recently rising; for if it were subsiding or had recently subsided, we may suppose that time enough would have elapsed since its elevation to allow the calcareous deposit to harden into rock, and then, as the subsidence took place, the surface at the edge of the water would be hard rock, which would finally probably extend under the water as the latter encroached on the land. The depth, close to the shore, of the fine calcareous deposit also points to elevation, for in it I ran a pole nine feet. How much deeper it was I had no means of determining, owing to the length of the pole. Now, had subsidence been taking place, should we find this depth of calcareous mud close to the shore? It is perhaps possible, and it might be claimed that the greater the subsidence, the greater would be the depth of the mud; but by the time that nine feet of sediment had been laid down it is reasonable to suppose that the mud on the shore would have hardened, and then should we not find the water washing against a rocky shore?

As we approach the west side of Andros from the interior, the pines 
grow smaller and smaller, and the forest is often prolonged into points that run out in the swash and are composed of young and vigorous trees. There are also in the swash small and slightly elevated pieces of land barely above the level of the surrounding ground, and on these are growing young pines. These facts show that the pines are advancing as fast as the conditions admit. Now, we may fairly suppose that within very recent geological times the atmospheric conditions were practically the same as now, and that the outward growth of the pines is limited by the elevation of the land from the influence of the salt water. Now, had the land once been as high as at present, it is fair to suppose that the pines would have taken possession of the places they now occupy; and if subsidence was in progress, they would now be being driven back from their vantage ground. And we may also suppose that before the change from elevation to subsidence had taken place, time enough to allow the pines to grow old would have elapsed; and hence were the island now sinking, or rather had it recently been sinking, we should expect to find on the western shore the pine forest with an array of old and dying trees facing the sea, and it would not be surprising if some dead pines were found standing in the water. None of these appearances are to be found.

The mangroves, too, point to elevation, for I find recorded in my note-books instances of mangroves, far above high-water mark, that were apparently dying, but none were seen in situations that indicated that the water was becoming too deep for them, as would probably be the case if the land had been recently sinking.

These facts have perhaps been treated with too much detail; but when I had been only to Nassau, and had seen the active erosion that was taking place, I was inclined to think that the islands were sinking, and was afterwards forced by the facts given above to alter my conclusion. That most of the cays are being worn away and reduced in size is evident. The vegetation is being driven backward, as indicated by the old and gnarled appearance of the bushes and by the rhizomorphs that remain where the plants once grew. But on the west side of Andros the water is so shallow for a long distance seaward that there is practically no erosion of the land by the waves. A little bank of coral sand and foraminifera raised slightly above the level of the swash is the only evidence of the action of the water. 


\section{Formation of the Cays north of New Providence}

The position, size, and shape of these larger cays have already been noted. Before attempting to explain the manner in which I believe they were formed, I will briefly describe the appearance of the reef at Nicol's Town, Andros, and also that at Rose Island, near Nassau.

At Nicol's Town the reef was about a quarter of a mile from the shore, and the water varied from ten to eighteen feet in depth. The reef was almost entirely composed of the great Madrepora palmarum, with some small patches of $M$. cervicornus. Both of these corals were growing luxuriantly, and their tips were close to the surface of the receding waves. The reef at Rose Island, however, contained very few specimens of $M$. palmarum, but many of $M$. cervicornus, and also large heads of what are popularly known as "brain corals," but which of the genera so designated I am unable to state. "The receding waves left the top of the reef bare, and exposed the sea fans and alcyonoid corals that were growing on the top. Toward the shore the reef sloped gradually downward into a bank of sand, or, in other words, the sandy bottom sloped upward to the top of the reef, which thus presented a very different appearance from the one at Nicol's Town, where the corals rose from the bottom. These facts show, I think, that the Rose Island reef is an old one, while the Nicol's Town reef is in what we may call its prime. A study of the chart of New Providence shows, running along its northern shore, a number of reefs, some of which are marked nearly dry at low water. Now, in order to convert these reefs into land it is only necessary that they should be slightly elevated or that sand should be deposited on top of them. And this, I believe, is the way in which the cays known as Hog Island, Rose Island, Salt Cay, and Quarantine Cay have been formed. In other words, I believe they have been formed in the same manner as L. Agassiz explained the formation of the cays of southeastern Florida. He argues, however, that as the cays nearest the land, and hence those first formed, are no higher than those farther seaward; it follows that during their formation the land was stationary. Professor Heilprin, ${ }^{1}$ on the other hand, has proved that the Florida peninsula is, or has lately been, rising. I think I have shown that the Bahamas, or at least the islands of New

\footnotetext{
${ }^{1}$ Trans. Wagner Free Inst. Sci., Vol. I.
} 
Providence and Andros, have very recently been rising; and yet, although I have no measurements, I venture to state that Salt Cay, the most seaward one, is as high if not higher than Hog Island, that lies inside of it.

To return to Florida. It would seem at first as if the conclusions of Professor Heilprin precluded the possibility of the cays being formed as suggested by Agassiz; for if we suppose a cay to be formed while the land is rising, and then that another forms to seaward, and this process to continue until three or four cays were formed one outside of the other, it seems as if the first one would be higher above the level of the sea than the last, and this Agassiz ${ }^{1}$ states is not the case. When I first read Agassiz's memoir I was much impressed with the strength of his arguments. But Heilprin's in regard to elevation are conclusive; and although he did not visit the lower part of the peninsula, it is probable that its movement is in the same direction as that portion examined.

It will, however, be noticed that Agassiz lays no stress on the effects of the erosion that takes place so rapidly on all islands of coral formation.

I believe that the views of these two eminent observers can be brought into harmony by considering the effects of erosion. Let us suppose a cay has been formed of calcareous material thrown up by the waves to a height of fifteen or twenty feet. Then, while the cay to seaward was being formed, the erosion would take place on the one already made, and whether its height above the sea increased, remained constant, or decreased would depend upon the relative effects of the elevation and erosion. It is not improbable that these two forces might balance each other; and if this were so, it is easy to show diagrammatically that any number of cays could form, one after the other, to seaward, and yet the first be no higher than the last above the level of the sea. And this argument also applies to the cays near Nassau. It is probable that the ocean would throw up some of the cays higher than the others, and also that a slight difference in height would not be observed by the unaided eye.

1 "Report on Florida Reefs," Mem. Mus. Comp. Zoöl., Vol. VII, No. I, p. $3^{6 .}$ 


\section{The Formation of the Bahamas}

As previously stated, the islands lie on the eastern and northern edges of the Great and Little Bahama Banks. The only exceptions are Great Bahama Island, the Biminis, and some others that are exceedingly small.

As I have visited only New Providence and Andros, I hesitate to do more than suggest that the other islands of the banks have been formed by the action of the waves and wind in the same manner as the cays near Nassau.

A visit to the other islands of the group would be well repaid, for some of them, as San Salvador, Rum Cay, and Inagua, have apparently been formed in a different manner from those on the Great Bank. And it is interesting to note that Dr. Bryant ${ }^{1}$ describes Inagua as a raised atoll. And Crooked Island and Acklin together resemble in a remarkable manner the shape of the Keeling Atoll. ${ }^{2}$ Should these be proved portions of an elevated atoll, it would be interesting, as they would be only exceeded in size by the atolls of the Maldiva Archipelago, which are the largest known. ${ }^{3}$ The islands of the Caicos Bank also resemble the form of an old atoll, and the bank is still larger than that on which Crooked and Acklin islands are situated.

In conclusion, it is interesting to note that Darwin and Professor Dana, although they never visited the Bahamas, have, from a study of the charts, come to diametrically opposite conclusions in regard to the evidence they present of elevation or subsidence. Professor Dana states "that "the Bahamas show by their form and position that they cover a submerged land of large area," and that "the long line of reefs and the Florida cays trending away from the land of southern Florida are evidence that this Florida region participated, though to a less extent than the Bahamas.... Thus the size of the islands, as well as the existence of coral banks and also the blankness of the ocean beyond, all appear to bear evidence to a great subsidence."

Darwin, on the contrary, says: ${ }^{5}$ proofs of elevation within recent Tertiary periods abound over nearly the whole area of the West

1 Proc. Bost. Soc. Nat. Hist., Vol. XI, I866, p. 63.

2 Darwin, "Coral Reefs," 3d ed., Pl. I, Fig. Io.

"Dana, "Corals and Coral Islands," p. Igo.

" "Corals and Coral Islands," p. 368.

b "Coral Reefs," 3d ed., p. 268. 
Indies, and hence it is easy to understand "the origin of the Great Bahama Banks, which are bordered on their southern and western edges ${ }^{1}$ by singularly shaped islands formed of sand, shells, and coral rock, some of them about too feet in height, is easily explained by the elevation of banks fringed on their windward side by reefs."

I think the facts I have given justify my conclusion in regard to the recent elevation of Andros and New Providence. It is probable that the elevation extended over the rest of the Bahamas, as caves exist on the other islands. What the Bahamas are doing to-day, of course, we cannot tell; but until we have proof to the contrary, we may assume that they are rising.

1 I have quoted this as given by Darwin. It is evidently a slip of the pen, as the islands are on the eastern and northern edges of the banks. 


\section{BAHAMAN BIRDS}

\section{BY JoHN I. NORTHROP}

(Abstract of address before the N. Y. Academy of Science)

After a few preliminary remarks upon the situation and size of the Bahamas, the speaker stated that a paper giving the details of the collection of birds would appear in the $A u k$ for January. He stated that all the species, seventy-four in number, were represented by the specimens on the table, but that he would only call attention to the most interesting.

The following birds were then exhibited and remarked upon: Mimocichla plumbea, Mimus polyglottos, Mimus Gundlachi, Polioptila carulea casiogaster, Seiurus aurocapillus, Geothlypis rostrata (a local form, slightly differing from the typical species found on New Providence), Callichelidon cyaneoviridis, Doricha evelyne, Sporadinus ricordi, Chordeiles minor, Icturus northropi (a new species of a genus not before reported from the Bahamas, and which has been described and named by Dr. J. A. Allen), Coccyzus minor Maynardi, Saurothera bahamensis, Phonicopterus ruber (the habits and mode of capture being described), Nycticorax nycticorax narvius (new to the Bahamas), Rallus coryi, Ardea bahamensis, and several other water birds.

The speaker also mentioned finding in the stomach of Antrostomus carolinensis an entire humming-bird sufficiently undigested to identify as Sporadinus ricordi.

He stated that the only mammals on Andros were bats, rats, and mice. The bat was Macrotus waterhousei, and the rat Mus rattus. The skin of the iguana, Cychera bcolopha, was exhibited, and the method of capture described. A few lizards were also shown, eight or nine species having been collected. The speaker had collected a number of species of snakes, the largest of which, a species of boaconstrictor, was exhibited. 
He briefly mentioned the large collection of invertebrates, and stated that, for the most part, it had not yet been worked up. One of the Anemones, however, is probably new. In this connection the speaker called attention to the interest connected with the geographical distribution of the Actiniaria, as Professor McMurrich considered them to be related to Pacific forms.

In conclusion, Dr. Northrop mentioned the collection of plants, comprising about seven thousand specimens, and representing about six hundred to seven hundred species. These, he stated, were being worked up by Mrs. Northrop, and twenty or thirty of the species were in all probability new.

The plants, as well as the birds, are decidedly Antillean in character and affinities. 


\section{THE BIRDS OF ANDROS ISLAND, BAHAMAS ${ }^{1}$}

\section{BY JOHN I. NORTHROP}

THE island of Andros is the largest of the Bahama group, being about ninety miles long, and forty or fifty miles across at the widest part. The southern portion is separated from the northern by shallow waters called "bights"; but these are so filled with cays, as to make it convenient to include all the islands under the general name of Andros.

Like all the others of the group, Andros is entirely of coral formation. The country is described by the natives as either "coppet," "pine-yard," or "swash." The first term is applied to the thicket of angiospermous trees and shrubs that occupies the ridge along the eastern coast. In most places this belt is very narrow, but near the southern end it extends several miles into the interior. Back of the coppet the land is comparatively level, and is covered by a forest of the Bahama pine (Pinus bahamensis). As one approaches the west coast, the pines become smaller and are mingled with palmettoes; finally both cease, and one sees spread before him thousands of acres of level plain, supporting scarcely any vegetation except countless dwarf mangroves. Here the ground is soft, and in wet weather almost entirely under water; hence the peculiar appropriateness of the local term "swash." Such is a brief description of the physical features of Andros. As might naturally be supposed, the coppet proved the best collecting ground for land birds, while the swash, and the lakes it contained, were well stocked with many aquatic species.

Although Andros is the largest of the Bahama Islands, it seems never to have been thoroughly explored by naturalists. The first record of Bahama birds is given by Catesby ${ }^{2}$ who visited Andros. In I859 and again in I866 Dr. Bryant made a collecting trip through the Bahamas and published the results in the Proceedings of the Boston Society of Natural History. His two papers are devoted to

${ }^{1}$ The Auk, Vol. VIII, No. I, January, I89r, pp. 64-80.

${ }^{2}$ Natural History of Carolina, Florida, and the Bahama Islands. 
ornithology and contain several references to Andros. Mr. C. J. Maynard, in 1884, spent some time on Andros and has published a few notes on its birds and described some new species. ${ }^{1}$ Mr. Cory also made an ornithological trip through the Bahamas, during which he visited the eastern coast of Andros. The results of his work are published in a well-illustrated volume entitled the "Birds of the Bahama Islands." Mr. Ingraham has also visited Andros, but I have been unable to find any notes by him on its avifauna. These, I believe, are the only naturalists who have ever honored Andros with a visit.

As this island is separated from both Florida and Cuba by nearly the same distance (about one hundred and twenty miles), the writer thought that a collection of its birds might prove interesting. It may, however, be well to state that the object of the visit to Andros was not to make a collection of birds, and that lack of time and assistance prevented us from obtaining larger series. Before going to Andros, some time was spent on the island of New -Providence, the western end of which is about twenty-five miles from the nearest point of Andros. There a few birds were collected, and these will be referred to in the list that follows. I was accompanied during the trip by Mrs. Northrop, who made notes on the occurrence of the birds, and more particularly on their songs and habits; and many thanks are due her for aid in the preparation of this paper.

We reached the northern part of Andros on March I4, I890, and left the southern end on the $3 \mathrm{~d}$ of July, during that time sailing almost completely around the island; exploring the majority of the creeks on both the east and west coasts, and passing through the bights in the central part. But the greater portion of the time was spent in the various negro settlements that were scattered along the eastern coast, hence we had ample opportunities for observation, and for obtaining what is probably a quite complete collection of the birds of the island.

Dr. Allen has kindly annotated the list, and thanks are due to him and to his assistant, Mr. Chapman, for aid in determining several of the species.

The collection includes 286 specimens; and in it are represented I 2 orders, 27 families, $5^{6}$ genera, and 74 species. Of these one, that Dr. Allen has done us the honor to name Icterus northropi, is new to science; and Nycticorax nycticorax nevius is new to the Bahamas,

${ }^{1}$ American Exchange and Mart and Household Journal, Vol. III. 
while Geothlypis rostrata has hitherto been found only on New Providence.

Unless otherwise stated, all the birds mentioned in this paper were actually obtained, and are now in the Museum of the School of Mines, Columbia College. I have added to the usual common names the local names of the birds.

I. Mimocichla plumbea Linn. Blue Thrasher. - This Thrush was common in the high coppet near Deep Creek, not far from the southeastern extremity of the island. Two specimens were also obtained near the northern end, but none were seen in the pines or in the swash on the west side. The bird hops about on the ground or on the lower branches of the trees, its black throat and red legs rendering it quite conspicuous. The stomach of one examined contained fruits. Those shot on June 28 were in condition to breed.

*2. Galeoscoptes carolinensis Linn. Catbird. - The Catbird was very common at Nicol's Town near the northern end of Andros duringMarch and April, and the last specimen was seen at Mastic Point about May 23.

3. Mimus polyglottos Linn. - Locally known as Brown Thrasher and Mocking-bird. My specimens were all collected near the northern end of Andros, the first on March 25, the last on April I6. They were quite common about our house at Nicol's Town, and their song could be heard at almost any hour of the day. It was loud and varied, each syllable being usually repeated three times. While on the western coast in June, we noticed one of these Mocking-birds, perched on the top of a palmetto. He was singing, apparently with all his heart, and attracted our attention by springing up into the air a few feet, then dropping to his perch again. This he repeated three times, singing all the while; we afterwards saw another bird go through the same performance.

The stomachs of the specimens examined contained the remains of the fruit of the gum elemi (Bursera gummifera), white ants, and pieces of snail shells.

[The three specimens referred to this species are indistinguishable from $M$. polyglottos of the Carolinas or Florida. They are hence very unlike the small form of Mimus from Inagua, recognized by $\mathrm{Mr}$. Sharpe as $M$. elegans. - J. A. A.]

4. Mimus gundlachi Caban. - This was more common than the species above described, as we found it wherever we landed. Its song is louder, clearer, and more varied than that of $M$. polyglottos. Its food consists of fruits of various kinds, but in the stomach of one specimen some small bones were found, probably those of an Anolus. The ovaries of a specimen shot on May I5 were much enlarged. The inhabitants of Andros do not distinguish between these two species, calling both either Brown Thrushes or Mocking-birds.

* The star prefixed to a number indicates that the species was observed by Mr. Scott at the Dry Tortugas. See note on page 87 . 
[The series of seven specimens presents a wide range of variation in both size and color. In the largest specimen the wing measures 4.73 inches, the tail 5.33 ; $\mathrm{n}$ the smallest specimen the wing measures 4.23 , the tail 4.60 . In one specimen the cheeks, sides of the throat, and the lower throat are thickly and heavily spotted, and the streaks on the flanks are very broad. In another the cheeks and sides of the throat are scantily barred, and the lower throat is without spots. The other specimens are variously intermediate between these. The difference in size may be in part sexual. $-\mathrm{J}$. A. A.]

5. Polioptila cærulea cæsiogaster Ridgw. Blue-gray Gnatcatcher, - This species was very common in the low shrubs that grew in the pine-yard. It was a most confiding little bird, and would sit within a few feet of you, twitching its head from side to side and uttering its low, wheezy little song, apparently very well pleased with its own efforts.

*6. Compsothlypis americana Linn. Parula Warbler. - This Warbler was collected in the northern part of Andros on March 26 and April 19. It was only seen in two localities, and was not common.

*7. Mniotilta varia Linn. Black-and-white Warbler. - First seen at Nicol's Town on March I7. In a week or two they became quite numerous about the house, but none were seen after the end of April. The three specimens procured were all males. Their stomachs contained the remains of beetles.

*8. Dendroica tigrina Gmel. Cape May Warbler. - This species was not common. Specimens were collected on March 22, and on April 20, two on the northeast coast, one near the west side.

9. Dendroica petechia Linn. Antillean Yellow Warbler. - But a single specimen, a female, was obtained near Mangrove Cay on June 24.

*Io. Dendroica cærulescens Gmel. Black-throated Blue Warbler.-One specimen was brought to us in Nicol's Town, April II; others were collected on April I9 at Red Bay on the northwestern end of Andros. They were quite common about the house for a few days, but none were seen after the above date.

*II. Dendroica striata Forst. Blackpoll Warbler. - The specimens were all obtained at Conch Sound on May 19 and 20 , although it was seen a little farther south on May 23, and even a day or two later.

I2. Dendroica vigorsii Aud. Pine Warbler. - This bird was one of the most common species in the pine-yard. The five specimens collected all proved to be females. The stomachs of those examined contained insects and small fruits.

I3. Dendroica discolor Vieill. Prairie Warbler. - This was by far the most common of the migratory Warblers. It was collected on the northern end of Andros from March 22 to April I2, and a few were seen during the latter part of April.

* I4. Dendroica palmarum Gmel. Palm Warbler. - A single specimen, a female, was shot at Mastic Point, May 2; it was hopping about on the ground under the small mangroves.

* I5. Seiurus aurocapillus Linn. Ovenbird. - This species was collected in several localities on the northern end of the island. At Red Bay on the west side it was quite common, and the natives knew the bird well under the name of the 


\section{THE BIRDS OF ANDROS ISLAND, BAHAMAS}

"ground walker." All whom we questioned on the subject were certain that the bird remained throughout the year, and some said that they had seen its nest." A specimen was collected by the writer on New Providence during January, and the last time that we observed it was in the first week of May. The stomachs of those examined contained the remains of insects.

[Four specimens taken on Andros Island, near the end of April, probably represent a local resident form, differing slightly from the North American stock in having the bill rather larger, the crown patch deeper orange, and the black lines bordering it and the black streaks below slightly heavier. Should these differences prove tolerably constant, they are too slight to render it desirable to designate the form in nomenclature. - J. A. A.]

I6. Geothlypis rostrata Bryant. Nassau Yellowthroat. -This species is new to the island, all the specimens previously known being from the neighboring island of New Providence. The first we saw was brought to us by a boy at Nicol's Town, March 2I. It was afterwards seen at Red Bays, Conch Sound, and later at Mangrove Cay on June 25. It frequents the thick underbrush of the coppet, and was always seen quite close to the ground. G. trichas was also collected, but the difference between the two birds was very noticeable, G. rostrata being considerably larger and much lighter in color. Its song was also louder and sweeter.

[The single specimen, male, is nearer G. rostrata than any other of the described forms, differing from it in its much shorter and slenderer bill, with the crown of a deeper and more bluish gray. Mr. Ridgway, who has examined the specimen, says: "Intermediate between type of G. rostrata and G. tanneri; bill entirely like the latter; color above brighter olive-green than in either." While doubtless representing a well-marked local race, it seems hardly worth while to give it a name on the basis of a single specimen. - J. A. A.]

* I 7. Geothlypis trichas Linn. Maryland Yellowthroat. - This species was seen on both the east and the west side of Andros from April I 2 to I9, but there is no note of its appearance later. Of the five specimens collected, four were males. It is interesting to note that Dr. Bryant states that of a flock of birds flying past his vessel in the harbor of Grassy Creek, in the southern part of the island, on April 20, I859, all were males.

*18. Setophaga ruticilla Linn. American Redstart. - This Warbler was first seen at Nicol's Town on April ro, and the last specimen was taken May 20; one was seen a month later, however, on the west coast.

Since this paper was written an interesting article by Mr. W. E. D. Scott has appeared in the $A u k$, , on the "Birds observed at the Dry Tortugas, Florida, during Parts of March and April." As I was collecting on Andros during the same time, I thought it would be interesting to note the species common to both places and have hence prefixed an asterisk to those mentioned in Mr. Scott's paper. A reference to his paper will show that he secured many Warblers that I did not, and a comparison of his dates with mine shows that with the exception of Mniotilta

${ }^{1}$ Cory states that it is migratory. - "Birds of Bahamas," p. $7 \mathrm{x}$.

2 Vol. VII, p. 301. 
varia, Dendroica tigrina, D. caerulescens, and Geothlypis trichas, the birds were observed later in Andros than at the Dry Tortugas. The commonest Warbler at the latter place was $D$. palmarum, of which I only secured one specimen, and no more were seen, while $D$. discolor, the commonest Warbler in Andros, was "not uncommon" with Mr. Scott. I doubt, however, if any inference of importance can be drawn from these facts.

In regard to the occurrence of the Warblers above mentioned it may be worth while to state that they appeared in "waves." The most noticeable of these was on April I8. We had been at Red Bays on the west side for a week, and had seen very few birds about, but a bird wave must have arrived during the night of the I8th, for the next day the grove about the house was full of birds, - the Blackthroated Blue, the Blue Yellow-back, the Redstart, Black-and-white Warbler, and Vireo altiloquus barbatulus were seen here for the first time, and in considerable numbers.

I9. Cœreba bahamensis Reich. Bahama Honey-creeper. "Banana Bird." - Common throughout the island except in the swashes. The state of the generative organs of those taken near the end of March indicated that the birds were nearly ready to breed.

*20. Callichelidon cyaneoviridis Bryant. Bahama Swallow. - This beautiful Swallow was first seen on New Providence and was afterwards found to be abundant on Andros, particularly in the clearings. They generally flew quite close to the ground. Dr. Bryant in the Proceedings of the Boston Society of Natural History, Vol. VII, page III, says that of those collected by him up to April 28, the genital organs exhibited no appearance of excitement. On April I5 $_{5}$ I collected a male with the testes much enlarged. The people told me that the Swallow breeds on the island, building under the rocky ledges, but we were not fortunate enough to find a nest.

2I. Vireo crassirostris Bryant. Large-billed Vireo. - Common at most places on the island, and its cheery little song was almost constantly heard from the bushes and low trees that the bird frequents. On May 24 the generative organs of the male were enlarged.

[The four specimens seem distinctly referable to V. crassirostris. - J. A. A.]

*22. Vireo altiloquus barbatulus $C a b$. Black-whiskered Vireo. - The first specimen of this bird was seen at Red Bays on the western side of the island, about April 18 . On our return to the east coast we found it common, and later noted it as quite abundant at all our stopping places; and its song, so well described by Dr. Bryant as "whip Tom Kelly, phew," was one of the most common notes of the coppet. Dr. Bryant says that the seven specimens collected by him were all males, and thinks that the females "had not arrived by the I $3^{\text {th }}$ of May." As I collected the first female on May 24, having previously shot two males, this surmise is probably correct. The genital organs were noted as being enlarged from May to to June 5, when the last specimen was shot. Some of the birds were mated and apparently ready to breed.

23. Spindalis zena Linn. - This bird, called by the natives "Tom James' Bird" and "Robin Redbreast," was very common in the coppet and the pines. It 
is one of the most conspicuous birds of the island, as well as one of the tamest, being quite often caught by the children. They seemed to be particularly fond of the fruit of the gum elemi (Bursera gummifera) and of the ripe figs. About May zo the genital organs were enlarged.

*24. Piranga rubra Linn. Summer Tanager. - A single specimen, a male, was taken at Red Bays, April 19. We showed it to some of the natives, but they had never seen any like it. As its color would render it conspicuous, we may infer that it was not a regular visitor, but, as stated by Cory in his "Birds of the West Indies," p. 85, is only accidental in the Bahamas.

25. Loxigilla violacea Linn. Violet Grosbeak. - Known by the natives as the "Spanish Paroquet," and quite abundant both in the coppet and the pines. The males vary much in color, some being a brilliant black, while others are only dusky; this difference is more apparent in living than in dead specimens. Both sexes also vary in size. Some of these birds were brought to us alive by the negro children, and I soon learned by experience that they not only were pugnacious but could inflict quite a painful bite with their strong beaks. The generative organs of a male collected May zo were considerably enlarged.

26. Euetheia bicolor Linn. Grassquit. - Very common both in the pineyard and in the coppet, and the most abundant species of land bird on the island. They were very tame and allowed one to approach within a few feet, and while we were at Nicol's Town, several of them flew through the house at various times. They seemed to vary a great deal, some of the males having the head and breast black, while others were much lighter with only the throat and chin black, more like the average female; in these the under mandibles were also much lighter. They seemed to have mated even in April, as they were usually seen hopping about in pairs.

27. Icterus northropi Allen. Northrop's Oriole. - (See Pl. I.) Description and notes of this bird were published in the $A u k$ (Vol. VII, p. 343, October, I890).

28. Agelaius phœeniceus bryanti Ridgw. Bahaman Red-winged Blackbird. This bird was found generally distributed over the island, and was the presiding genius of its creeks and swashes. On the west coast especially his flute-like "okralee" was the most familiar note. The birds were usually in small flocks, but there always seemed to be a great preponderance of males. Beyond doubt, however, the latter knew that their plainly dressed mates were near, much oftener than we, for a number of times we saw one half raise his wings so as to expose his brilliant epaulets, and sing with all his heart, fluttering his wings at every note. On two occasions while visiting a large mangrove near Mastic Point, we remained until after sunset and watched the Redwings fly out to roost there. The mangrove, about two miles from the shore, was very large, and accommodated hundreds of feathered guests nightly. There were Man-o'-war Birds, White-headed Pigeons, and Louisiana Herons, but the most numerous as well as the noisiest lodgers were the Red-winged Blackbirds. They began to arrive about five o'clock, flying in from the mainland by twos and threes, or sometimes singly, until at last the portion of the mangrove that they occupied was seemingly alive with them. There 
must have been several hundred, males, females, and young, and they kept up a constant chorus of hoarse chirps, screams, and gurgling "okralees" until quite a while after the sun had set.

29. Pitangus bahamensis Bryant. Bahama Kingbird. "Fighter." - Not uncommon in many parts of the island. I have nothing to add to Dr. Bryant's account of its habits, ${ }^{1}$ except that in the stomach of one some fruits of the gum elemi were found, showing that its diet was not entirely insectivorous.

3o. Blacicus bahamensis Bryant. Bahaman Wood Pewee. - This small species, of which Dr. Bryant says he only saw three specimens, all in the month of March, we found common on the island, not only in the coppet, but also in the pineyard, and even occasionally in the swashes. At one of our stopping places two or three were always to be seen flying about near the house. They were very fearless, and several times flew so close as to touch us. One seemed to be particularly tame and would fly in at the door or window or about our heads with perfect unconcern. He had several favorite perches about the house, on one or another of which he was to be found at any time of day, cocking his little head from side to side, in wait for unwary flies.

3r. Myiarchis lucaysiensis Bryant. Rufous-tailed Flycatcher. - Not as abundant as the preceding species, but quite often noted, especially in the northern part of the island. Seven specimens were collected, all of which were males.

[The series of seven specimens agrees with one of Bryant's original specimens in the Lawrence Collection at the American Museum of Natural History, and differs from a small series of $M$. sagre in being much larger, with the bill narrower, and in lacking the strong yellow suffusion of the lower abdomen, crissum, and axillaries, which in $M$. lucaysiensis are either nearly pure white or only faintly tinged with pale yellow. It is apparently a strongly marked form. - J. A. A.]

$*_{32}$. Tyrannus dominicensis Gmel. Gray Kingbird. "Fighter."-Quite common on the island, but most abundant near the coast. On May $3^{\text {I we found }}$ a nest of this species in a small mangrove between tide marks. We had often seen similar nests before, but could not be certain what bird had made them. The nest was composed of small sticks rather compactly arranged. It was about nine inches in diameter and four or five inches in depth. In the center was the cup, about three inches in diameter and two or three deep, very neatly lined with a fiber from some palm, probably from the spathe of the cocoanut palm. While exam. ining the nest, the old birds flew from the shore and swooped over us, much agitated. There were no eggs. On June Ig another nest was found in a mangrove on the west side of the island. This time I shot both birds and secured the nest and the one egg it contained. The latter was ovate in shape, 1.94 inches long, and .70 wide; white with a few small brownish and lavender spots and blotches, mostly near the larger end. It is stated that in Jamaica the nest of this bird "is seldom found in any other tree than that of the palm kind." 2 In Florida, however, it builds in the same situations as in the Bahamas. We found it a rather

1 Proc. Bost. Soc. Nat. Hist., Vol. VII, p. 108.

2 Baird, Brewer, and Ridgway, "North American Birds," Vol. II, p. 322. 
quiet bird, although it has been described as noisy. Once we saw it attack a Buzzard, and persistently drive it away.

33. Chordeiles minor Cab. Cuban Nighthawk. - Quite abundant; sometimes a dozen or more were seen flying about in the dusk. It is called "Piramidig" by the natives, on account of its cry, which to us, however, sounded more like "Pir-ra-me-quick-quick." Those procured were shot in the daytime, on the western side of Andros, on June I 7. They were sitting motionless on the hot dry plain, and did not fly until we were within a very few feet of them. Even when disturbed they would alight again very shortly, and crouch close to the ground as before.

*34. Antrostomus carolinensis Gmel. Chuck-will's-widow. - Three specimens were taken, two of which were disturbed in the woods during the daytime, and the other shot at dusk. Upon examining the stomach of the first one I shot, I found, amid an indistinguishable mass of brownish matter, a small bone, about half an inch long, that looked like the leg of a small bird. The next one examined contained in its stomach the partially digested remains of an entire Humming-bird, enough of which was preserved to identify it beyond doubt as Sporadinus ricordi. "The remains of a small bird are said to have been found within the stomach of one of this species." I One collected on May I5 contained remains of beetles and winged ants in its stomach. The testes were much enlarged, being about half an inch in length, but I am not sure that the bird breeds on the island.

35. Doricha evelynæ Bourc. Bahama Woodstar. - Well distributed over both New Providence and Andros, and as common in the pines as in the coppet. They are both pugnacious and curious, for one day we watched one chase a Dendroica discolor off a tree, and follow it some little distance, and while walking through the woods one of these birds would often alight close by or hover over our heads, as if examining us, and they flew through the house a number of times. They seemed to alight on the branches quite as frequently as other birds, and we often watched them perch and preen their feathers. Their little silvery trill was a quite common note in the pines, and for a while we thought it the song of some bird in the distance until we caught sight of the tiny songster almost above our heads. They do not always confine their attention to flowers, for one day a Doricha, after fluttering about the basket of flowers in my hand, made a dart at a goodsized spider in a web close by, and to our surprise demolished it and was off again in a moment. Of the numbers that we saw at New Providence, none were adult males, and of those collected on Andros there was a large preponderance of females.

On one occasion we had the good fortune to see a male who was evidently displaying his charms. The female was perched on a branch of a low shrub and before her the male was performing. His wings were vibrating rapidly in the usual manner, and thus supported in the air he swung rapidly to and fro, at the same time rising and falling, a movement very difficult to describe, but almost exactly like that of a ball suspended by an elastic thread that stretches and contracts as the ball swings back and forth. This exceedingly graceful movement

1 Baird, Brewer, and Ridgway, "North American Birds," Vol. II, p. 4I3. 


\section{THE BIRDS OF ANDROS ISLAND, BAHAMAS}

was executed through a small arc for a few minutes, and then was suddenly changed. The male expanded his tail, showing the cinnamon of the webs, and then threw himself rapidly and violently from side to side in an almost horizontal line. During this latter part of the display a rustling sound was produced, probably by the vibrations of the wings, and a few short sharp notes were uttered. He then darted suddenly at the female who all the while had been sitting apparently unconcerned, seemed almost to touch her with his bill, and then flew rapidly away. Shortly afterward the female left, flying in another direction. During all of the display the two birds were facing each other and not more than six or eight inches apart, and the gorget and tail of the male were exposed to their fullest advantage.

36. Sporadinus ricordi Gerv. Ricord's Humming-bird. - This was abundant on Andros, where all my specimens were obtained, none being seen on New Providence. Curiously enough, in this species, there seemed to be a great preponderance of males, and out of the seven specimens collected, but one proved to be a female. It may safely be said that most of those we saw were males, as the females are quite different, being smaller and lacking the beautiful blue green gorget. The ovaries of the bird collected May I6 were not enlarged. It is probable that both Doricha evelyne and Sporadinus ricordi breed on the island; that one of them certainly does was evidenced by a nest that I was shown. It was lined with cotton, and was evidently the nest of a Humming-bird.

37. Crotophaga ani Linn. Ani. Rain Crow. - Frequently seen on both New Providence and Andros, and always in small flocks of three or more. They were not as tame as most of the land birds, being on the contrary quite shy, and it was a difficult matter to get very close to them, as one of the flock was almost certain to espy you, and to notify the others with his loud warning "wee-eep," a note in which the second syllable was much higher than the first, and more prolonged. On one occasion while walking through the woods during a rain, we noticed what looked like a square black board suspended to a pine some distance from the path. On investigation the black object was discovered to be seven Crotophagas, sitting in a row on a small dead branch, and crowded as closely together as possible. They were not asleep, however, for when I had approached within thirty or forty feet, a warning note was heard, then another and another, as they one by one took flight.

38. Saurothera bahamensis Bryant. Great Bahama Cuckoo. - The "Rain Crow," as the natives call this bird, was said to be abundant, but we got but one mature specimen and two young ones. Dr. Bryant states that they were quite common on New Providence in I859. They fly about with a weak, wavy motion, and the people told us that they could catch them after a short chase, as they soon grew tired. Our specimens were obtained on the following dates, May 20, May 26, June I3; all on the eastern side of Andros. The one taken on May 20 was a mature female, and the ovaries were enlarged, some of the ova being over one-fourth of an inch in diameter. In the stomach were grasshoppers and a small lizard. The stomachs of the others contained the remains of insects. Their bills were soiled, probably from investigating the leaves of the epiphytic Tillandsias, as these 
ants found in their stomachs seemed to be of the same species as those inhabiting these plants. The description given by Cory ${ }^{1}$ agrees with the two young specimens, but the adult has a black band near the end of the tail-feathers, which are tipped with dirty white, except the two middle ones. This agrees with the description given by Bryant."

39. Coccyzus minor maynardi Ridgw. Maynard's Cuckoo. - This bird, like the last species, was said to be common, but we succeeded in getting but four specimens, and during our stay saw about as many more. Their note was quite frequently heard, however, and usually from the mangroves or near by. The stomachs contained the remains of small insects and grasshoppers. On June 28 the testes were much enlarged (one-half inch long).

$*_{40}$. Ceryle alcyon Linn. Belted Kingfisher - Not uncommon on either New Providence or Andros, but no specimen was obtained. One was noted on the west side on April 23, and another on the east side two days later, although Dr. Bryant states that he saw none after April I. We thought that we saw oneMay 26, but were not near enough in this instance to be certain.

4I. Dryobates villosus maynardi Ridgw. Bahaman Hairy Woodpecker. All our specimens were taken on Andros, where the bird was abundant, especially about the clearings.

*42. Sphyrapicus varius Linn. Yellow-bellied Sapsucker. - A single specimen, a female, was shot near Nassau about February 5 .

43. Strix pratincola Bonap. American Barn Owl. - Although but few of these birds were seen, I judge from what the people said that they are common. One that I shot at Nicol's Town had its home under an overhanging ledge on the precipitous side of a large hole about one hundred feet in diameter, known as the "ocean hole." Here, in a deep recess, on March 25, we found two young ones not yet able to fly; and near by were the remains of the common rat of the island ( $M$ us rattus). As is usual with this species, there was no nest, the birds resting on the ground. Around them for some distance the ground was covered with the rejected food balls, composed of the bones and hair of the rodent above mentioned, and as no other bones were noticed, it is probable that the Owl's principal article of diet was rat.

44. Speotyto cunicularia dominicensis Cory. Burrowing Owl. - The specimen doubtfully referred to this subspecies was shot at Nassau in February. Another, presumably of the same subspecies, was seen on the southern part of Andros in June, flying about the low shrubs near the shore, but we. were not fortunate enough to get it.

[A single specimen is referred to this form, which it much more resembles than it does the Florida form, being much darker than the latter. - J. A. A.]

*45. Falco columbarius Linn. Pigeon Hawk. - A single specimen, a male, was shot at Mastic Point on Andros on May 2. The bird was rare. A larger Hawk also was seen, but no specimens were obtained.

1 "Birds of West Indies," p. 159.

${ }^{2}$ Proc. Bost. Soc. Nat. Hist., Vol. IX, p. 280. 
46. Cathartes aura Linn. Turkey Buzzard. "Crow." - Very common on Andros, but more were seen on New Providence.

47. Columba leucocephala Linn. White-crowned Pigeon. - Very abundant during the spring and summer. In the evening we often watched them flying from Andros in the direction of New Providence. The people said that they were going to Green Bay, a distance of fifty miles. A female shot on June 28 was almost ready to lay.

48. Columbigallina passerina Linn. - Called "Ground Dove," and "Tobacco Dove" by the natives. Exceedingly common both on Andros and New Providence. They generally fly about in small flocks of three to six, and are very tame.

49. Zenaida zenaida Bonap. Zenaida Dove. - Not as abundant as the White-crowned Pigeon, but not uncommon in the coppet. They were shy, and were heard much oftener than seen.

5o. Charadrius squatarola Linn. - A pair of Black-bellied Plovers was shot on the shore near Red Bays, Andros, on April I4.

5. Agialitis vocifera Linn. - The Killdeer was first seen near Fresh Creek on the Ist of June, and on the 7 th two were shot. They both proved to be males, with the testes enlarged to about . 5 inch in diameter. The species was not abundant, and but few were afterward seen.

52. Egialitis wilsonia Ord. Wilson's Plover, - Abundant and very tame. It was found on almost all the sandy beaches, where it would'sometimes run along just ahead of us for nearly half a mile, appearing quite to forget that it could get out of our way by flying. This species is known to breed in the Bahamas. ${ }^{1}$

53. Hæmatopus palliatus Temm. American Oyster-catcher. "Sea-pie." One of these birds was obtained near Red Bay on April I5. It was feeding on the extensive sand flats at low tide. Later, others were occasionally seen in similar places. It is said to breed in the Bahamas. ${ }^{2}$

54. Himantopus mexicanus Miill. Black-necked Stilt. - A flock of these birds was seen in one of the lakes on the west side of Andros on April 2r, and a pair were secured. We afterwards found them occasionally in the marshes. On June 17 we saw quite a number of these birds in the swash near Wide Opening. Our man said that this was the kind of place in which they bred, and later we found a nest. It was simply a slight depression in the ground, and contained four ovate eggs of an olive-green color, blotched with brown, measuring $I_{4}^{1}$ to $I^{\frac{1}{2}}$ inches by $\mathrm{I} \frac{1}{4}$.

55. Symphemia semipalmata Gmel. Willet. - Commonly known as "Tell-Bill-Willy." Very abundant in all the creeks and swashes. The ovaries of those shot on May $3^{\mathrm{r}}$ were much enlarged.

*56. Actitis macularia Linn. Spotted Sandpiper. "Sandbird." - One specimen, a female, was shot on the west side of the island, April 2I, and was the only one seen during our trip. As Cory obtained only three specimens in 1879 , it is doubtful if it is a resident.

1 Cory, "Birds of Bahamas," p. I4.

${ }^{2}$ Bryant, Proc. Bost. Soc. Nat. Hist., Vol. VII, p. I2r. 
57. Rallus coryi Maynard. Bahaman Rail. - A single specimen from Conch Sound, Andros, April I5. It was shot and skinned by Mr. Alexander Keith, a Scotch gentleman, to whom the writer takes pleasure in acknowledging his indebtedness for this and many other favors, while on Andros. This bird was known as the Marsh Hen, and is said by the people to be common, but we never met with it again. On May 28 a woman brought us three eggs that she said were those of a Marsh Hen. They are ovate to elongate-ovate in shape, and are nearly cream color with chocolate spots and blotches irregularly distributed over the entire surface but much more numerous at the larger end. Mingled with these chocolate spots are others of a lavender gray. The eggs are of the following dimensions: $1.60 \times 1.30 ; 1.70 \times 1.22 ; 1.70 \times 1.20$ inches.

[A single specimen in fine (unworn) plumage is provisionally referred to Rallus coryi. It is, however, about the size of ordinary $R$. crepitans, from which it differs in the gray edgings of the plumage, being much broader than in even extreme examples of that form, resulting in a generally grayer effect. - J. A. A.]

58. Ardea herodias Linn. Great Blue Heron. "Arsnicker." - Not uncommon:

59. Ardea rufescens Gmel. Reddish Egret. - Abundant in the swashes. The white phase of this bird was also common; many were seen, and three specimens were collected.

6o. Ardea tricolor ruficollis Gosse. Louisiana Heron. "Switching-neck." - Two pairs were obtained at Mastic Point in May. They were breeding in a large mangrove, about a mile and a half from the shore. These birds agree with Ridgway's description ("Manual North American Birds," p. I3I) except that the upper part of the throat is not white, but rufous mixed with white. These also agree with Cory's description of $A$.cyanirostris. But a specimen collected on the western side of Andros answers to Cory's description of A. leucogastra, var. leucoprymna, and differs from the above specimens in the following points. The forehead and crown are much darker, being quite black; the throat has more rufous, and the neck is darker. The nest of the Mastic Point birds was composed of small mangrove sticks, laid so as to make a circular structure nine inches in diameter and three or four deep. There was a slight depression in the top, in which were placed a few sticks, parallel to each other, and on these were four eggs. The latter vary in shape; some being ovate, while others are almost equally pointed at both ends. They are nearly malachite green ${ }^{3}$ in color, but with a slightly bluer tinge. The measurements are as follows: I. 7 I-I.84 $\times$ I.29-I.34 inches.

*6r. Ardea cærulea Linn. Little Blue Heron. - One specimen, shot at Stafford Creek May 5. No more were seen, which seems curious, as Dr. Bryant regarded this as the most common species of Heron; ${ }^{2}$ and Cory states that it was abundant during the winter, but no adults were taken by him. ${ }^{3}$ My remarks, however, only apply to Andros, and the bird might be common in other localities.

62. Ardea bahamensis Brewster. Bahama Green Heron.-Locally known

1 Ridgway, "Nomenclature of Colors."

${ }^{2}$ Proc. Bost. Soc. Nat. Hist., Vol. VII, p. I 20.

a "Birds of the Bahamas," p. I7I. 
by the expressive name of "Poor Joe." We found it quite abundant in the creeks and swashes, and at Fresh Creek collected what is very probably the young of this species, hitherto undescribed. The top of the head is clove-brown with a slightly greenish gloss, streaked with cinnamon-rufous. The rest of the head, front of the neck, and the breast are white striped and mottled with sepia and bistre. The back and the remainder of the neck are olive, having the feathers edged with cinnamon-rufous. The tail is similar to the adult. Lower parts are gray, the feathers being edged with white; and the scapulars and wings are clovebrown, the coverts having an elliptical mark of wood-brown and being edged with cinnamon-rufous; the rest of the wing-feathers having a deltoid mark of white at the end. The bill is ochre yellow, darker above, and shading into black near the end of the upper mandible. Legs olive.

*62. Nycticorax nycticorax nævius Bodd. "Golden."-The Blackcrowned Night Heron is new to the Bahamas, and is said by the people to be abundant, although we did not see very many individuals. Two were secured at Conch Sound, March 30.

*64. Nycticorax violaceus Linn. Yellow-crowned Night Heron. About as abundant as the last species. Both the above species of Nycticorax are locally known as "Goldens," pronounced "gaulings."

65. Phœnicopterus ruber Linn. - A few Flamingoes were seen on the western coast of Andros in April; but later, in June, when the breeding season had commenced, we found them very abundant. A pair were shot on June I8, and they were then ready to lay. We were told that one of their breeding places was near Big Cabbage Creek, and a day was spent in an unsuccessful attempt to find their nests. They were described to us, however, by reliable people, who also stated that the birds sat upon their nests "like any other bird," and not with their legs hanging down on either side. The birds are exceedingly shy, and in the open swashes it is difficult to get within shot; for while stealing warily toward them, you are very apt to hear a warning "gong, gong," and off tlies the entire flock, a streak of flame against the sky. The Flamingoes, when feeding, push their head into the mud under water; and this fact is taken advantage of to secure them. While the head is under water the negro walks rapidly forward, taking about ten steps and then stopping. By that time the bird will probably lift its head and look around. The negro stands motionless and screens his face with a branch of a tree until the Flamingo, apparently satisfied that the new object is inanimate, quietly resumes his feeding, and the negro advances as before. I was assured by intelligent men that in this way they had sometimes captured the birds alive with their hands. That the bird feeds in the manner described above is well shown by its mouth, which is peculiarly adapted to sifting from the mud any mollusks or crustaceans that might serve as food, and the gape of the bill when opened to its fullest extent is only about half an inch. We were also told that a screen is sometimes built of palm leaves, and behind this the native can easily advance within shot of the flocks. A large number of young birds are yearly destroyed by the people for food. We ate the bodies of those we obtained and found the flavor most delicious. We had for a long time been living practically upon flour and hominy, 
and this may have made the Flamingo seem better than it really was; nevertheless I think it would bear comparison with any of the much sought after game-birds. The stomachs of the pair I obtained contained no fish, but many small shells and much mud.

66. Dendrocygna arborea Linn. Tree Duck. - A flock of Ducks was seen in a lake on the west side on April 2I, but we could obtain no specimens. A negro who was with us said that they were "Whistling Ducks," and, as Cory" states that this species was quite abundant on Andros, the negro was probably right. I was told that earlier in the year the Ducks were very numerous on the swashes. The ground about the lake mentioned was pitted with shallow holes about two to four inches in diameter which our man said had been made by the Ducks while feeding, when the place had been covered with water. I also saw a smaller Duck near Wide Opening on June I 7. In answer to my questions, I was told that it was a "Summer Duck."

*67. Fregata aquila Linn. Man-o'-war Bird. - A number of these birds had their roosting place in the large mangrove near Mastic Point, already spoken of in connection with the Red-winged Blackbirds. We were told that formerly they used to breed there, but that of late years they had gone farther from the settlement.

*68. Pelecanus fuscus Linn. Brown Pelican. - A few seen, and one, a young bird, obtained.

*69. Phalacrocorax dilophus floridanus Aud. Florida Cormorant. - Cory, in his "Birds of the Bahamas," states that this is an abundant species, but in his "West Indian Birds" says it is accidental in the Bahamas. We often saw it, and on June I6, while sailing through the Northern Bight, found them breeding on a small island known as Cormorant Cay. Here were old and young birds, some not able to leave the nest, but the majority able to walk. Those still in the nest were covered with a soft sooty down, and their gular sacks were pale yellowish white, darker near the bill. The nests were about eighteen inches in diameter, and about one foot in height, roughly constructed of sticks.

*7o. Anous stolidus Linn. Noddy. - A flock of these birds was seen near Fresh Creek, on June 6. They were occasionally seen afterward.

*7r. Larus atricilla Linn. Laughing Gull. - Abundant. First noted early in April.

*y2. Sterna maxima Bodd. Royal Tern. - One specimen shot April I4 on Long Sound on the northern coast of Andros. A few more were seen, but the bird was not common.

*73. Sterna fuliginosa Gmel. Sooty Tern. - Since our return a specimen of this bird has been kindly sent to us by Mr. Alexander Keith of Andros. We saw none of this species while on the island.

74. Sterna anæthetus $S c o p$. Bridled Tern. - Abundant on a small bay near Fresh Creek, where they breed. The people call this and the preceding species "egg birds," and during the season collect and eat their eggs. They were not

$$
1 \text { "Birds of Bahamas," p. } 183 .
$$


breeding when we were at Fresh Creek early in June, but they were almost ready to breed.

*75. Sterna antillarum Less. Least Tern. - Abundant off Fresh Creek on a small cay near the larger one occupied by the Bridled Tern; neither, however, seemed to trespass on the ground of the other. 


\title{
DESCRIPTION OF A NEW SPECIES OF ICTERUS FROM ANDROS ISLAND, BAHAMAS ${ }^{1}$
}

\author{
By J. A. Allen
}

THRougr the kindness of Mr. John I. Northrop, of the School of Mines, Columbia College, New York, I have the pleasure of making known a new species of Icterus from Andros Island, one of the larger islands of the Bahaman group. During four months spent recently on Andros Island, Mr. and Mrs. Northrop devoted much attention to birds, collecting about seventy species, among them several new to the Bahamas, as well as the novelty about to be described, which adds not only a new genus to the Bahaman fauna, but a new species to science. The species is represented by nine specimens, three of which are adult males, one immature male, one adult female, three immature females, and another immature specimen of which the sex could not be determined. As shown by Mr. Northrop's notes given below, he found the species not uncommon. It is known to the residents of the island as the "Cocoanut Bird," and is said to be resident throughout the year.

\section{Icterus northropi, sp. nov.}

Adult Male, - Whole anterior half of the body, as far as the middle of the breast below, and including the interscapulium above, together with the wings (except the lesser and median coverts), and tail, deep black; rest of the body, the thighs, lesser and median wing-coverts, edge of the.wing, lower wing-coverts and axillars, rich lemon-yellow; greater wing-coverts and primaries very narrowly edged, and the outer tail-feathers very narrowly tipped with white. Bill and feet black; lower mandible with the basal third bluish. In one specimen the longest two lower tail-coverts are mixed yellow and black; in the other specimens they are all wholly yellow.

Adult Female. - Similar to the male, except slightly smaller, and with the black a little less lustrous.

Young. - Immature birds of probably the second year are olivaceous gray above, brighter and more yellowish on the front of the head; lesser wing-coverts, lower back, rump, upper tail-coverts, and whole lower surface greenish yellow,

${ }^{1}$ The $A u k$, Vol. VII, No. 4, October, I89o, pp. 344-346. 


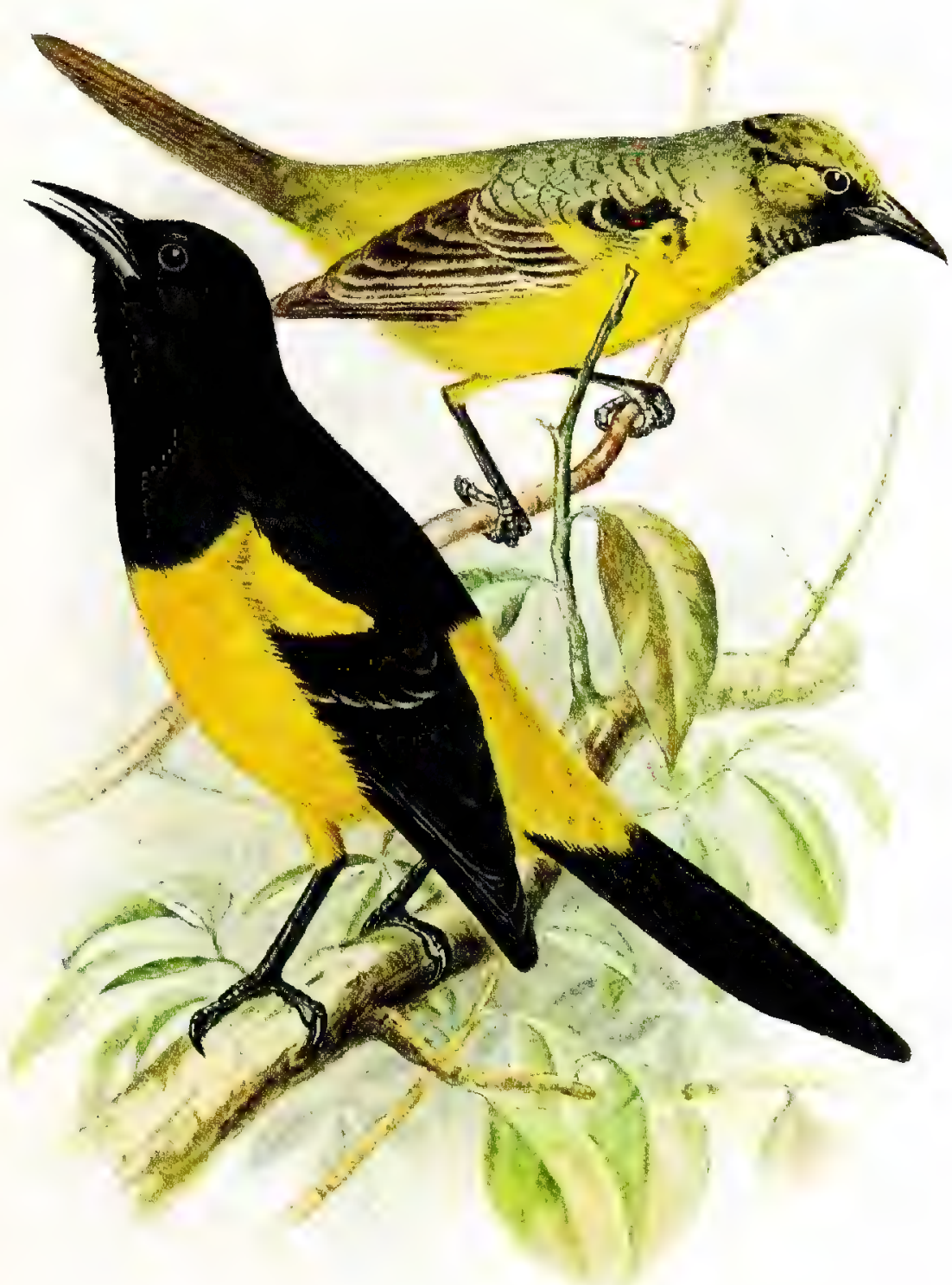

ICTERUS NORTHROPI ALLEN.

1. ADULT MALE.

(26 N $\triangle T$ SITF)
2. YOUNG MALE. ( $3 / 5$ NAT. SIZE.) 

brightest on the rump and middle of the abdomen; median wing-coverts pale sulphur-yellow; greater coverts brown, edged with whitish; chin, throat, and cheeks much mixed with black, which here prevails over the yellow; there are scattered black feathers over the breast and head, and in one specimen blackish patches on the outer edge of the scapulars and sides of the breast; wings and tail brown, the remiges edged with whitish, and the rectrices with olive.

Other specimens in a less advanced stage are similar, except that there are fewer black feathers intermixed with the yellow, the chin and the front edge of the cheeks alone being decidedly blackish, and the back is less olivaceous.

Measurements. - Length (from skins) .205 mm. (I95-2I5 mm.); wing $94 \mathrm{~mm}$. (90-99 mm.); tail $94 \mathrm{~mm}$. (90-97 mm.); culmen $22 \mathrm{~mm}$. (2I-22 mm.); tarsus $25 \mathrm{~mm}$. (24-27 mm.).

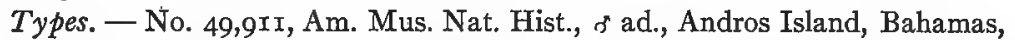
June, I89o; Mr. and Mrs. John I. Northrop. No. 49,9I2, Am. Mus. Nat. Hist., ad., Andros Island, Bahamas, April r6, r8go.

The extent and distribution of the black and yellow in the adults are the same as in $P$. wagleri except that the tail-coverts are yellow instead of black; the tint of the yellow is nearly as in I. dominicensis, from which it differs in having the whole lower parts yellow from the middle of the breast posteriorly, instead of the yellow being confined to the sides of the abdomen and crissum. The two species agree in general size, but in $I$. northropi the bill is much stouter than in $I$. dominicensis.

It is surprising that a bird so conspicuous, and apparently so common, as this should hitherto have escaped observation, Andros Island having been several times previously visited by ornithologists.

Mr. Northrop has kindly presented the types of this species to the American Museum of Natural History, and contributes the following notes on its habits and distribution:-

"The above species of Icterus was first collected by us at Nicol's Town, near the northern end of Andros, on April 8, 189o. We had been there nearly a month when one morning a new note called us out of the house, and we saw three or four of these birds flying about the shrubs near by. They were so tame and unsuspicious that when one was shot, the others kept their positions undisturbed until they met a similar fate. Of the three we got then, one was a male, one a female, and one we could not determine, but they were all in immature plumage. Two weeks or so later, while on a trip to the west side, we saw a number of these birds near Red Bays, and this time were fortunate 


\section{DESCRIPTION OF A NEW SPECIES OF ICTERUS}

enough to get a male and female in full plumage. They were flying about the palmettoes, and the flower stalk of an agave which was a mass of golden blossoms and a great attraction to all the birds in the neighborhood, as the flowers contained a large amount of nectar. While near here one day, we heard a great commotion, and approaching the scene, found two of these young birds fighting so violently that we got almost near enough to take them up in our hands. The only sound we heard them utter here was a rather plaintive call of two notes; but a month later, on May 22, we heard their song. It was a sort of whistle of eight or nine notes, very sweet and pleasing, and almost always given with the same intervals, and the same arrangement of notes. The bird was observed in two other localities, the last time, June I8, near Wide Opening on the west side. It seems to inhabit the more open portions of the island, near the coast, as we never saw any inland.

"The natives say that it builds its nest in the cocoanut trees, and is always about them, hence its local name of 'Cocoanut Bird.' They also told us that it remained throughout the year; that the eggs were pure white; and that the young birds differed from the old in plumage. From the condition of the organs of generation, it seems that the bird breeds during the month of June.

"The stomachs of those examined contained the remains of a grasshopper, beetles, and seeds; hence it may be inferred that its food consists of fruits and insects." 


\title{
THE NORTHROP COLLECTION OF CRUSTACEA FROM THE BAHAMAS ${ }^{1}$
}

\author{
By W. M. RANKIN
}

(Pls. XXIX-XXX)

The Crustacea collected by Dr. and Mrs. Northrop in the Bahama Islands in 1890 were sent to me by Professor Osborn, with the request that I prepare a report on them. The following list is the result. Such a list is of necessity largely a mere catalogue of names, but it is hoped that it may be of service in the preparation of a more extensive fauna of the Bahamas when such a work shall be undertaken. It has been with the idea of giving a little wider interest to the list that with each species the range of distribution has been given, and also the West Indian islands noted where the species has been found, although this latter record is no doubt incomplete. I hope at least these notes of distribution may serve as a suggestion for the fuller record of the distribution of these species among the West Indies. The synonymy I have made brief, merely citing the original author and usually a reference to the work where a complete synonymy may be found.

The letters $(a),(b)$, etc., in many species indicate the various series of specimens in the collection as they were arranged originally or, in some cases, sorted out by me after their receipt. To these series I have fortunately been able to add some notes made by Dr. Northrop when the collections were made, and recently sent me by Mrs. Northrop.

Among the sixty-seven species collected I have determined four as new species, and one I have ranked as a new variety. There is also published for the first time a figure of Stenopus levis. For the careful drawings of the figures I am indebted to Mr. R. Weber. I wish to express my obligations to Miss Rathbun, of the National Museum, for assistance in identifying a few species; and also to Dr. Ortmann, of Princeton, who has kindly assisted me in many ways and to whom this report owes much of any value it may possess.

' Ann. N. Y. Acad. Sci. XI, No. I2, August, r898, pp. 225-258. 


\section{DECAPODA \\ BRACHYURA-CATOMETOPA \\ Family Ocypodidæ Ortmann \\ I. Ocypode arenaria (Catesby)}

Cancer arenarius Catesby, History of the Carolinas, II, p. 35, I 77 r. Kingsley, Proc. Acad. Nat. Sci., Phil., I880, p. I84.

Ortmann, Zoö.l Jahrb., VII, p. 765, r894.

(a) 5 ठै, 2 ․ Near Nassau, N.P., Jan. 24, I89o.

Range: South shore Long Island to Rio Janeiro.

Collected at Cuba, Jamaica, St. Thomas, New Providence.

2. Uca platydactyla (Milne-Edwards)

Gelasimus platydactylus Milne-Edwards, Hist. des Crustacés, II, p. 5 I, I837.

G. heterocheles Kingsley, 1.c., I880, p. I37.

(a) 4 d. Under sides of stones, Dix Point, near Nassau, N.P., Feb. 4, I89o.

(b) 8 t, 7 ㅇ.

Range: East and west coasts Central America, West Indies.

Collected at Jamaica.

\section{Uca vocator (Herbst)}

Cancer vocator Herbst. Naturder Krabben u. Krebse, III, pt. IV, I804.

Gelasimus vocator Martens; Kingsley, l.c., I880, p. I47.

(a) I $\mathbf{z}$. Bahama Islands.

Range: East coast of America, west coast of Mexico, Panama, West Indies.

Collected at Bahamas, Cuba, Hayti, Jamaica.

4. Uca stenodactyla (M. Edwards et Lucas)

'Gelasimus stenodactylus, M. Edwards et Lucas in D'Orbigny's Voyage, I843.

Kingsley: I.c., I880, p. I54. Ortmann: l.c., p. 760, I894.

(a) I $\hat{o}$. Common in mud on west side of Andros Island, near Red Cays, April I7, I8go. 
Range: West Indies, Central America, east and west coast. Collected at Cuba.

\section{Uca leptodactyla (Guérin Ms.)}

Gelasimus leptodactylus Guérin Ms. (types in Phila. Acad.).

Gelasimus stenodactylus Kingsley, Proc. Acad. Nat. Sci., Phila., p. I55 (part), I880.

(a) Io $\delta, 59$. Holes in sand between tides about $5^{-6}$ in. deep, very shy, near Ft. Montagu, Nassau, N.P., Jan. 28, '9o.

Some of these specimens were sent to the United States National Museum, where they were identified by Miss Rathbun, and to whom I am indebted for the following note of description:

"Uca leptodactyla belongs to the division of the genus.in which the front between the eyes is broad and the body is short, broad and subcylindrical. It is most nearly related to $U$. stenodactyla; the chief differences are as follows: in $U$. stenodactyla the body is much higher than in leptodactyla, being usually higher than long. The anterior margin of the carapace from the base of the eyestalk to the anterolateral angle is much more oblique in leptodactylo, and the lateral margins are much more convergent posteriorly. The carapace of leptodactyla is, therefore, more pentagonal than that of stenodactyla. In stenodactyla the lateral margin is much dilated behind the anterolateral tooth, which is not the case in leptodactyla. The inner surface of the hands differs as follows: the short ridge on the palm at the base of the dactylus is perpendicular to the base of the propodos in leptodactyla; while it is oblique in stenodactyla. In both species the tubercular ridge running obliquely upward from the lower margin makes an angular turn at the middle of the inner surfaces, and is continued until near the upper margin. In leptodactyla this continuation runs parallel to the line of tubercles at the base of the dactylus; in stenodactyla the continuation is directed obliquely towards the line at the base of the dactylus."

\section{Family Gecarcinidæ Dana}

\section{Gecarcinus ruricola (Linnæus)}

Cancer ruricola Linnæus, Sys. Nat. Ed. Io, I, p. 626, I758.

Gecarcinus ruricola Leach. Edin. Encyc., VII, 430, I8I4. Ortmann, l.c., p. 740, I894. 
(a) I $\hat{\sigma}$. Bahama Islands. (Dry.)

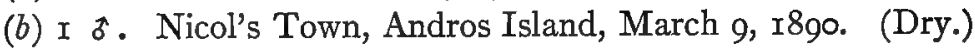

Range: West Indies, Mexico.

Collected at Cuba, Jamaica, Hayti, Martinique.

7. Cardisoma guanhumi (Latreille)

Latreille, Ency. Méth., Hist. Nat. Insectes, X., 685, I825.

Ortmann, 1.c., p. 735, I894.

(a) $\mathrm{x} \delta, \mathrm{x}$ \& , $\delta \mathrm{I}$, juv. Move sluggishly, make holes in the ground by side of road under trees, Nassau, N.P., Jan. 25, I8go.

Range: East and west coasts of Central America, West Africa.

Collected at Cuba, Jamaica, Hayti, St. Thomas, Barbadoes.

\section{Family Grapsidæ (Dana)}

\section{Leiolophus planissimus (Herbst)}

Cancer planissimus Herbst, l.c., p. 3, Pl. LIX, I804. Miers, Ann. Mag. Nat. Hist., Ser. 5, I, I878, p. I53.

(a) 3 ठే, I \&. On shore, just south of Ft. Montagu, Nassau, N.P., Jan. 22, 1890 .

(b) 2 व juv. Ocean side of Salt Cay, N.P., Jan. 3I, I89o. Range: "Cosmopolitan, except the colder seas." Ortmann. Collected at Jamaica.

\section{Plagusia depresse (Fabricius)}

Cancer depressus Fabricius, Entom. Sys. Suppl., p. 406, I775. Miers, Challenger, Brachyura, p. 272.

(a) $2 z$. Salt Cay, New Providence. (Dry.)

Range: Charleston to Brazil, Mediterranean to St. Helena.

Collected at Cuba, Jamaica.

\section{Io. Sesarma cinerea (Say)}

Sesarma ricordi Milne-Edwards, Annal Sci. Nat. (3) Zool. t. 20, p. I $83, \mathrm{I} 853$.

Ortmann, Carcinologische Studien, Zoöl. Jahrb., Bd. X, p. 329, I897.

(a) I \& with ova. Under side of stones, Dix Pt., near Nassau, N.P., Feb. 4, I 890 . 
Range: West Indies.

Collected at St. Domingo, Hayti, Jamaica, St. Thomas, Virgin Islands.

\section{Pachygrapsus transversus (Gibbes)]}

Gibbes, Proc. Am. Ass. Adv. Sci. III, p. I81, I850.

Kingsley, l.c., I88o, p. I98.

(a) $4 \hat{\jmath}$, juv., 3 \& with ova. Nassau, N.P., under stones Jan., I890.

Range: "Warm and temperate waters of both hemispheres." Ortmann.

Collected at Cuba, Jamaica, Virgin Islands, Barbadoes.

\section{Grapsus grapsus (Linnæus)}

Cancer grapsus Linnæus, Sys. Nat. ed. X, I, p. 630, I758.

Smith, Trans. Conn. Ac., IV, I880, p. 256. Ortmann, l.c., p. 703, r894. Kingsley, I880, p. I92; r879, p. 401 .

(a) I ð, 2 ๆ. Near Nassau, N.P., Jan., I89o.

Range: Warm waters of both hemispheres.

Collected at Cuba, Jamaica, Hayti.

\section{I3. Goniopsis cruentatus (Latreille)}

Grapsus cruentatus Latreille, Hist. Nat. des Crust., VI, p. 70, I803. Kingsley, l.c., I880, p. I9o. Ortmann, l.c., p. jor, I894.

(a) I $\delta$. (Dry.)

(b) 2 . On shore near Nassau, N.P., Jan. 23, I8go.

- Range: American and African coasts of the Atlantic Ocean.

Collected at Cuba, Jamaica, Hayti.

BRACHYURA-CYCLOMETOPA

Family Oziidæ (Ortmann)

I4. Eriphia gonagra (Fabricius)

Cancer gonagra Fabricius, Sp. Ins., p. 505, I781.

Ortmann, l.c., p. 480, I894.

(a) I $\delta$. In pools on shore, Nassau, N.P., Jan. 2I, I89o.

(b) I \&. Dix Point, near Nassau, N.P., Feb. 4, I8go.

(c) I 5 . Salt Cay. Ocean side, near New Providence, Jan. $3^{\mathrm{I}}$, I8go. 
Range: Atlantic coast from Carolina to Rio Janeiro. Collected at Bahamas, Cuba, Jamaica, Hayti, Barbadoes.

I5. Domœcia hispida Eydoux et Souleyet

Eydoux et Souleyet, Voy. Bonite, I, Crust., p. 235, r842. Ortmann, I.c., p. 478, I 894 .

(a) I $\&$, juv.

Range: West Indies, Florida, Cape Verde Islands, Senegal, Pacific islands.

Collected at Cuba, Jamaica, St. Thomas, Guadaloupe.

\section{I6. Panopeus herbstii Milne-Edwards}

Milne-Edwards, Hist. Nat. Crustacés, I, p. 403, I834.

Benedict \& Rathbun, Proc. U. S. Nat. Mus., XIV, p. 358, I89I.

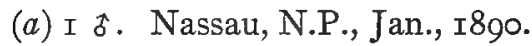

Range:, Rhode Island to Brazil.

Collected at Bahamas, Jamaica, St. Thomas, Curaçao, Trinidad.

\section{I7. Panopeus occidentalis Saussure}

Saussure, Rev. et Mag. de Zoöl. (2), IX, p. 502, I857.

Benedict \& Rathbun, l.c., p. 360 .

(a) I ?. Near Nassau, N.P., Feb., I8go.

(b) I $\delta$. On shore near Nassau, N.P., Jan. 22, I89o.

Range: Atlantic from South Carolina to Brazil.

Collected at Jamaica, Old Providence, Guadaloupe, Curaçao, Trinidad.

\section{I8. Panopeus americanus Saussure}

Saussure, Rev. et Mag. de Zoöl. (2), IX, p. 502, I857.

Benedict \& Rathbun, l.c., p. 380 .

(a) I §, 4 \&. Near New Providence, Bahamas, Jan.-Feb., I8go.

(b) I t.. On shore, near Nassau, N.P., Jan. 22, I 890.

(c) I ż. Nassau, N.P., Feb. 24, I89o, Dix Point.

Range: West Indies to Brazil.

Collected at Jamaica, St. Thomas. 


\section{Family Xanthidæ Ortmann}

\section{I9. Chlorodius floridianus Gibbs}

Gibbs, l.c., p. I75, I850.

(a) I 9 . Collected in pools and under stones, New Providence, and neighboring cays.

(b) I of. Dix Point, Nassau, N.P., Feb. 24, I8go.

(c) I $\tilde{z}, 2$ \&. Near New Providence, Jan.-Feb., I8go.

(d) I o , 3 q. On shore near Nassau, N.P., Jan. 22, I8go.

Range: Florida to Brazil.

Collected at Jamaica, St. Thomas, Barbadoes.

\section{Lophactæa lobata (Milne-Edwards)}

Cancer lobatus Milne-Edwards, Hist.Nat. Crustacés, I, p. 375, x834.

Lophactea lobata A. Milne-Edwards, Nouv. Arch. Mus. Hist. Nat., I, p. 249, Pl. XVI, fig. 3, I865.

(a) I \&. Quarantine Station, Jan. 25, I89o.

Range: West Indies, Gulf of Mexico, Bermuda.

Collected at Jamaica and the Antilles.

\section{I. Heteractæa ceratopa (Stimpson)}

Pilumnus ceratopus Stimpson, Ann. Lyc. Nat. Hist. N.Y., VII, p. 2I5, I862.

Heteractea ceratopus Kingsley, l.c., I879, p. 396.

(a) I + . Dix Point, Nassau, N.P., Feb. 24, I89o.

(b) I 9 . Quarantine station, N.P., Jan. 25, I8go.

Range: Florida and West Indies.

Collected at Guadaloupe.

\section{Actæa acantha (Milne-Edwards)}

Cancer acanthus Milne-Edwards, Hist. Nat. Cr., I, p. 390, ı834. Actea acantha A. Milne-Edwards, Nouv. Arch., I, p. 278, Pl. XVI, I865.

(a) I $ة$. Quarantine station near Nassau, N.P., Feb. Io, I89o.

Range: Florida Keys, West Indies.

Collected at Jamaica, Guadaloupe. 


\section{PORTUNINEA \\ Family Portunidæ (Ortmann) \\ 23. Callinectes larvatus Ordway}

Ordway, Boston Jour. Nat. Hist., VII, p. 573, I863.

Rathbun, The genus Callinectes, Proc. U. S. Nat. Mus., XVIII, p. 358, r 896 .

(a) I $\hat{\sigma}$, I $q$, spur. juv. On shore, just south of Ft. Montagu, Nassau, N.P., Jan. 22, I89o.

Range: Florida to Brazil, West Indies, Cape Verde Islands, Africa. Collected at Bahamas, San Domingo, Jamaica, St. Thomas.

\section{Callinectes tumidus (Ordway)}

Ordway, l.c., p. 574, 1863 .

Rathbun, l.c., p. 359, I896.

(a) I d. Nassau, N.P., Jan. 2I, I89o, common in shoal water.

Range: Florida to Brazil, West Indies.

Collected at Jamaica, Hayti, Old Providence.

\section{Acheloüs depressifrons (Stimpson)}

Amphitrite depressifrons Stimpson, Ann. Lyc. Nat. Hist. N.Y., VII, p. 58, I862.

Acheloüs depressifrons Stimpson, ibid., p. 223.

(a) I \&. Quarantine station, N.P., Jan. 25, I890.

Range: South Carolina to Florida, Bermuda, West Indies. Besides this specimen from New Providence, the Princeton Museum possesses one from the Virgin Islands; the only two localities reported from the West Indies.

\section{Acheloüs ordwayi (Stimpson)}

Stimpson, Notes on N. Am. Crustacea, Ann. Lyc. Nat. Hist., N.Y., p. 224, I862.

Smith, Trans. Conn. Acad., II, p. 9.

(a) I of . Quarantine station, N.P., Jan. 25, r89o.

(b) I \&, with ova. Dredged near Nassau, N.P., Jan. 22, I8go.

Range: Florida and West Indies.

Collected at St. Thomas. 


\section{Acheloiis tumidulus Stimpson}

Stimpson, Bull. Mus. Comp. Zoöl., II, p. I49, I870.

(a) I §o. Dredged near Nassau, N. P., Jan. 22, I89o.

Stimpson describes two specimens from the coast of Florida. The species is probably only the young of $A$. ordwayi, as it only differs from the latter (as noted by Stimpson) in the less prominent frontal spines.

MAIOIDEA

\section{Family Periceridæ Miers}

\section{Macrocœloma eutheca (Stimpson)}

Pericera eutheca Stimpson, Bull. Mus. Comp. Zoöl., II, p. I I2, r87o. Rathbun in Proc. U. S. Nat. Mus., Vol. XV, No. 90I, p. 25 I, 1892. (a) I ․ Dredged near Nassau, N.P., Jan. 22, I890.

Range: Florida, West Indies.

Collected at Cuba.

\section{Microphys bicornutus (Latreille)}

Pisa bicornuta Latreille, Encyc. Méth., Hist. Nat. Insectes, X, p. I4I, I825.

Microphys bicornutus A. Milne-Edwards, Nouv. Arch. Mus. Hist. Nat., VIII, p. 247, I872.

Rathbun, l.c. (No. 9or), p. 253.

(a) $2 \hat{\delta}, 5 \%$. Common under rocks between tides and in pools, New Providence, Jan., r8go.

(b) I f. Quarantine station, N.P., Jan. 25, I8go.

(c) I ㅇ. Nassau, N.P., Jan., I890.

(d) I $\vec{\delta}$. On shore near Nassau, just south of Ft. Montagu, Jan. 22,1890 .

(e) I \& , juv. "Sea gardens," near Nassau, N.P., Feb., I8go

$(f)$ I $\delta$, juv. Ocean side of Salt Cay, Feb. 6, I8go.

(g) I $\hat{o}$, juv. Nassau, N.P., Feb. I5, I8go.

(h) I \&, juv. Salt Cay, N.P., ocean side, Jan: 3I, I89o.

Range: Florida, West Indies to Brazil, Bermuda.

Collected at numerous islands of the West Indies. 


\section{Othonia aculeata (Gibbes)}

Hyas aculeata Gibbes, 1.c., p. I7 I, I850.

Rathbun, l.c., p. 255, I892.

(a) I . . On shore just south of Ft. Montagu, Nassau, N.P., Jan. 22, I8go.

Range: Florida and West Indies.

Collected at Cuba, Bahamas, Jamaica, St. Thomas, Guadaloupe.

\section{I. Othonia lherminieri Schramm}

Schramm, Crust. de la Guadaloupe, 20, 1867.

(a) I 1,2 \%. On shore near Nassau, Jan. 22, I8go.

The three specimens in the collection are broken and imperfect. I place them doubtfully in this species.

Range: Atlantic coast; South Carolina to Brazil.

Collected at Cuba, Jamaica, St. Thomas, Guadaloupe.

\section{Mithrax pilosus Rathbun}

Rathbun, 1.c., p. 262, Pl: XXXIX (No. 90I), I892.

(a) I 5 . Near New Providence, Jan., I8go.

(b) 2 s, fragmentary. Salt Cay, ocean side, New Providence, Jan. 3 r, I89o.

Miss Rathbun's four specimens were collected in Abaco, Bahamas.

\section{Mithrax cinctimanus (Stimpson)}

Mithraculus cinctimanus Stimpson, Ann. Lyc. Nat. Hist. N.Y., VII, p. I86, I862.

Rathbun, 1.c., p. 268 (No. 90I), I892.

(a) I . Dix Point, Nassau, N.P., Feb. 24, I89o.

(b) I f. Quarantine station, N.P., Jan., 25, I89o.

(c) I \&, broken. Near Nassau, N.P., Feb., I89o.

(d) I \& , juv. Nassau, N.P., Jan., I89o.

Range: Florida coast, West Indies, Gulf of Mexico.

Collected at Andros Island, Jamaica, St. Thomas, Guadaloupe.

\section{Mithrax forceps (A. Milne-Edwards)}

Mithraculus forceps A. Milne-Edwards, Miss. Sci. au Mexique, pt. 5, I, p. Iog, I875. 
Rathbun, l.c., p. 267 (No. gor), $\mathrm{x} 892$.

(a) 6 \&, mostly young. Ocean side of Salt Cay, Feb. 6, I8go.

(b) I $f$, fragmentary. Nassau, N.P.

(c) 3 ๙े. "Sea gardens," near Nassau, N.P., Feb., I8go.

(d) I $\hat{\delta}, 2$ \&, juv.

Range: From North Carolina to Brazil and Guiana.

Collected at Nassau, Bahamas, Old Providence, St. Thomas, Curaçao.

\section{Mithrax sculptus (Lamarck)}

Maia sculpta Lamarck, Hist. Anim. sans Vert., V, p. 242, I818. Rathbun, 1.c. (No. 90I), p. 27 I, I892.

(a) I f, I q. Quarantine station, N.P., Jan. 25, I89o.

Range: Florida, West Indies to Venezuela, Surinam.

Collected at numerous localities in the West Indies.

\section{Mithrax coronatus (Herbst)}

Cancer coronatus Herbst, Natur. der Krabben u. Krebse, I, p. I84, Pl. XI, fig. 63, I785.

Rathbun, 1.c. (No. 901), p. 272 , 1892 .

(a) I $\delta$. Salt Cay, ocean side, near New Providence, Jan. 3, I8go.

(b) 1 $\hat{\jmath}$, juv. Ocean side of Salt Cay, Feb. 6, I8go.

Range: Florida, West Indies, Central America, Brazil.

Collected at Abaco, Bahamas, Jamaica, Cuba, St. Thomas, Guadaloupe.

\section{Family Inachidæ Miers}

\section{Acanthonyx petiverii Milne-Edwards}

Milne-Edwards, Hist. Nat. Crust., I, p. 343, I834.

(a) I $q$, broken. Under rocks, between tides and in pools. Nassau, N.P., Jan., I8go.

Range: West Indies to Brazil and California to Chili, Galapagos.

Collected at Cuba, Jamaica, St. Thomas, Guadaloupe, Martinique.

DROMIIDEA

Family Dromiidæ Dana

38. Dromidia antillensis Stimpson

Stimpson, Notes on N. Am. Crust., Ann. Lyc. Nat. Hist. N.Y., VII, p. 7r, I862. 
(a) I \&. Nassau, N.P., Feb. 15, I89o.

Range: Florida, West Indies, Brazil.

Collected at Antilles, Jamaica, St. Thomas.

HIPPIDEA

\section{Family Hippidæ Stimpson}

\section{Remipes cubensis Saussure}

Saussure, Rev. et Mag. de Zoöl. (2), IX, p. 503, I857.

Ortmann, Die geog. Verbreit. der Decap. gruppe der Hippidea, Zoöl. Jahrb. IX, p. 219, I896.

Remipes scutellatus (Fabricius), Henderson, Challenger Anomura, $3^{8}$, I888.

(a) I9 \& with ova. Beach at Nicol's Town, Andros Island, April 4, I89o.

(b) 2 o, 9 \&. Quarantine station near New Providence, Jan. 25,1890 .

(c) I \&. Nassau, N.P., Jan., I8go.

Range: "American and African shores of Atlantic." Ortmann (l. c. supra).

Collected at Cuba, Jamaica, St. Christophers, Barbadoes.

\section{GALATHEIDEA.}

\section{Family Porcellanidæ Henderson}

\section{Porcellana sayana Leach}

Pisidia sayana Leach, Dict. d. Sci. Nat., XVIII, p. 54, I820.

Porcellana ocellata Gibbes, l.c., p. I90, I850.

Henderson, Challenger, Anomura, p. I09, I888.

(a) I $\delta$. Came out of a shell inhabited by a large hermit crab. Nassau, N.P., Jan. 26, I890.

Range: West Indies and Southern shores of United States.

Collected at Antilles, Jamaica, St. Thomas.

\section{I. Pachycheles panamensis Faxon}

Faxon, Mem. Mus. Comp. Zoöl., XVIII, p. 75, Tab. I5, I895.

Ortmann, Zoöl. Jahrb., X, r897, p. 293.

(a) I $\delta, 2$. Ocean side of Salt Cay, Feb. 6, I8go. 
Size of ${ }^{*} 5 \frac{1}{2} \mathrm{~mm}$. long, $5 \mathrm{~mm}$. broad; of $q 5 \mathrm{~mm}$. long, $6 \mathrm{~mm}$. broad. These specimens have been kindly examined for me by $\mathrm{Dr}$. Ortmann, who finds them identical with Faxon's type from Panama, and also very close to the Cape Verde $P$. barbatus A. Milne-Edwards. This is the first recorded specimen of $P$. panamensis from the West Indies.

\section{Petrolisthes armatus (Gibbes)}

Porcellana armata Gibbes, 1.c., p. I90, I850.

Petrolisthes armatus Stimpson, Ann. Lyc. Nat. Hist. N.Y., VII, p. 73, I862.

Ortmann, Zoöl. Jahrb., X., r897, p. 280.

(a) I 1, I \&. Ocean side of Salt Cay, Feb. 6, I89o.

Ortmann (1.c. supra) gives full synonymy of this species and makes its distribution circumtropical; West Indies to Brazil, Gibraltar, California to Panama, Indo-Pacific.

Collected at Cuba, Jamaica, St. Thomas, Barbadoes.

\section{Petrolisthes tridentatus Stimpson}

Stimpson, Ann. Lyc. Nat. Hist. N.Y., VII, p. 75, Pl. I, 1862.

(a) I $\delta$. Along shore, near Nassau, N.P., Feb. 20, I89o.

(b) 2 ơ, 5 \&: Salt Cay, N.P., ocean side, Jan. 3 I, I89o.

(c) 2 ot, I $q$. Under sponges, Nassau, N.P., Jan., I8go.

Range: West Indies.

Collected at St. Thomas, Barbadoes.

\section{PAGURIDEA}

\section{Family Cœnobitidæ Dana}

\section{Cœnobita diogenes (Latreille)}

Pagurus diogenes Latreille, Encycl. pl. 284, fig. 2 and 3.

Milne-Edwards, Hist. Nat. Crust., II, p. 240, Pl. 22, I837.

(a) 2 б. Nicol's Town, Andros Island, March 23, I89o.

(b) 2 б’, I . Nassau, N.P., Jan. I6, I89o.

(c) 2 \%. On beach, Quarantine station, near Nassau, N.P., I890.

(d) I $\%$, juv. In pools and under stones, New Providence and neighboring cays. 
Range: Florida to Brazil, West Indies, Bermuda.

Collected at Antilles, Cuba, Jamaica, Hayti, Turks Island, St. Thomas, Barbadoes.

\section{Family Paguridæ}

\section{Petrochirus granulatus (Olivier)}

Pagurus granulatus Olivier, Encyc. Méth., VIII, p. 640, I8II. Henderson, in Challenger, Anomura, p. 58, I888.

(a) $3 \hat{\delta}$. Largest about 8 in. long.

(b) I $\succsim$, I $९$. In shell of Strombus gigas, Nassau, N.P., Jan. 26, I8go.

Range: West Indies, Gulf of Mexico to Brazil, Cape of Good Hope.

Collected at Antilles, Cuba, Jamaica.

The common large West Indian hermit crab.

\section{6 (?). Clibanarius vittatus (Bosc.)}

Pagurus vittatus Bosc., Hist. des Crust., II, p. 8, pl. XII, I802.

Kingsley, Proc. Acad. Nat. Sci. Phil., p. 236 , 1878.

(a) I $\delta^{\star}$, imperfect. In small shell of Strombus gigas, beach near Nassau, N. P., Jan., I890.

(b) I (?), fragmentary. Near Nassau, N.P., Feb. I, I8go.

Range: Ft. Macon to Florida, West Indies, Brazil.

I refer these imperfect specimens doubtfully to this species. The chelre are wanting in $(a)$, and $(b)$ is too much broken to be of any value in the determination.

\section{7 (?). Clibanarius tricolor (Gibbes)}

Pagurus tricolor Gibbes, Proc. Amer. Assoc., p. I89, I85०.

(a) Several specimens.

(b) I $\delta$. South side New Providence, in small shells of Strombus gigas.

The determination is doubtful, as the specimens are very poor and have almost entirely lost their color. They are all withdrawn into the shells of various littoral mollusks. 


\section{Family Parapaguridæ Smith}

48. Parapagurus sp.

(a) 2 \%. Dredged, Jan. 22, I89o, Nassau, N.P.

Length of thorax 3 and $5 \mathrm{~mm}$. respectively.

I refer these imperfect, colorless specimens doubtfully to some species of Parapagurus.

\section{LORICATA}

\section{Family Palinuridæ Bate}

\section{Palinurus argus (Latreille)}

Palinurus argus Latr., Milne-Edwards, Hist. Nat. Crust., II, p. 300, 1837 .

(a) I $\delta, x$ \&. New Providence, Jan. 27, I89o. Holes in sand between tides, about $5^{-6}$ in. deep, "very shy." 1

(b) I \&. Nassau, N.P., Jan., I8go. (Dry.)

Range: West Indies to Brazil.

Collected at Antilles, Cuba, Jamaica.

\section{STENOPIDEA}

Family Stenopidæ Bate

50. Stenopus hispidus (Latreille.) (Pl. XXIX, fig. I.)

Palamon hispidus Olivier, Encycl., VIII, p. 666, I8I I.

Stenopus hispidus Latr., Regne animal de Cuvier, ed. 2, IV, p. 93 .

Bate, Challenger, Macrura, p. 2II, Pl. XXX.

Herrick, The Life History of Stenopus, Nat. Acad. of Sciences, Vol. V, p. 339 .

(a) I 6 . Nassau, N.P., Jan. 22, x89o. "In life the antennæ are carried in front, not bent back."

I note the characters of special importance in order to compare this already described species of Stenopus with the two species following. Rostrum with a median dorsal row of 6 spines bifurcated at extremity, a lateral row of 3 or 4 spines on each side of rostrum; no ventral spines. Back of the sixth dorsal spine a double row. Rostrum

${ }^{1}$ This label is marked as doubtfully belonging to this specimen. 
does not reach to end of peduncle of inner antennæ. Carapace of thorax very rough, with firm, sharp spines which are longer on the dorsal than on the lateral regions. Abdomen thickly armed with outwardly projecting spines. Third pereiopod long, abundantly armed with spines. The propodos with six rows above and below and two on each lateral surface.

Measurements: total length $50.5 \mathrm{~mm}$., length of cephalo-thorax I6. $5 \mathrm{~mm}$., of abdomen $34 \mathrm{~mm}$., of rostrum $6 \mathrm{~mm}$., of telson $9.5 \mathrm{~mm}$.

Unless the eastern form should prove distinct from the West Indian, we have a widely distributed species occurring in the warm waters of both hemispheres. It has been reported from: Indian Ocean (Olivier), Australia (Peron and Lesneur), Borneo and Philippines (Adams and White), South Pacific (Dana), Ambonia (DeMan), Fiji Islands and Bermuda (Bate), Cuba (Von Martens), Bahama Islands (Herrick).

I introduce a figure of this specimen (Pl. xxix, Fig. I), although not a new species, in order to compare it with the two following species, figures of which have not yet appeared.

\section{I. Stenopus semilævis Von Martens (Pl. xxix, Fig. 2)}

Von Martens, Ueber Cubanische Crustaceen, Arch. f. Naturgesch., Bd. $3^{8}$, p. I44, I872.

(a) I $\delta$, I \& with ova. Under large sponge, New Providence, Jan., I89o.

My specimens correspond very closely, except in certain minor particulars noted below, with the description given by Von Martens of a species "probably from the West Indies," which he found undescribed in the Berlin Museum and which he called S. semilavis.

Von Martens' description (l.c. supra) I reproduce: "Cephalothorax spiny; abdomen smooth; rostrum short, not longer than the peduncle of the inner antennæ, compressed laterally and prolonged as a ridge nearly to the sharply marked cervical furrow, above with four teeth, below teeth wanting. Carpus of third pair of pereiopods quadrangular as in $S$. hispidus, but the chelæ compressed, with smooth sides and not so long; chelæ, including the dactyl, twice as long as broad; the upper margin sharper than the under and smooth, the under serrated. The dactyl half as long as the palma; the back of the dactyl keeled, serrated. Length from tip of rostrum to tip of telson I $2 \mathrm{~mm}$. 
Length of third pereiopod $\mathrm{I}_{3} \mathrm{~mm}$. Breadth of chela $3 \mathrm{~mm}$. The fourth pereiopod shorter than third."

I note the following peculiarities in my specimens: Dorsal surface of rostrum with six teeth; the fourth and sixth have each a minute subsidiary tooth. Ventral surface with a single, not very prominent tooth. Both margins of the chelæ of the third pereiopods very finely serrated, a rather prominent keel on the upper margin. The third pereiopod of the right and left sides similar. Telson spiny. The large specimen ( $q$ ) is $15 \mathrm{~mm}$. long, the $\delta$ slightly smaller. Length of chelæ in $q$ $6 \mathrm{~mm}$., breadth $2.5 \mathrm{~mm}$.

Not having the opportunity of comparing the Bahama specimens with Von Martens' type I prefer to consider these slight variations as possibly due to imperfect description, and to place my specimens, provisionally, at least, with Von Martens' species.

$S$. semilcevis differs from $S$. hispidus mainly in the teeth of rostrum, the shorter rostrum, the proportionately shorter and thicker hand, the less spiny carapace of cephalo-thorax and the smooth abdomen.

\section{Stenopus scutellatus n. sp. (PI. xxix, Fig. 3)}

(a) I (?) ô. Under coral, near low water, Silver Cay, N.P.

Total length from tip of rostrum to tip of thorax $18 \mathrm{~mm}$. Length of rostrum $3 \mathrm{~mm}$., of cephalo-thorax $7 \mathrm{~mm}$.

Rostrum has a single row of ten spines on median dorsal line; back of the tenth a double row of three spines extend to the cervical furrow. On median ventral line of rostrum are six spines; no lateral spines on rostrum. Rostrum longer than in S. hispidus, extending beyond the peduncle of inner antennæ. Whole surface of carapace covered with delicate spines obscurely arranged in rows; usually curved forward, with a somewhat reflexed tip. Spines on dorsal surface of first two abdominal segments short and straight in a double row pointing forwards; on third segment several rows, stouter, pointing outwards; on the fourth, fifth, and sixth segments spines are longer, pointing backwards. In the middle of the posterior portion of the tergum of the third abdominal segment there is a polished, slightly elevated, shieldshaped area, with crenellated margins, about I mm. in length. The median tergal region of fourth segment is smooth and polished, surrounded by a row of appressed spines, the same being true to a less extent of the fifth segment. I have taken the specific name from this 
peculiar scutellar area on the third abdominal segment. This feature seems to correspond to a triangular but less prominent area on the similar segment in S. hispidus which is prolonged into a smooth dorsal ridge on the next segment.

Telson lance-shaped, with a double row of spines between which is a longitudinal groove about as long as the uropodal lamellæ, which are finely serrated on their margins, and, as the telson, fringed with stiff hairs.

Eyes on short peduncles which are armed above with three short spines projecting over the cornea, and with a few spines at the anterior margin. Cornea (in alcoholic specimen) bluish black. Inner antennæ; peduncle with a few weak spines at distal end of segments. Outer antennæ; peduncles with strong, forwardly projecting spines. Scale lined on inner margin with long closely set hairs and prolonged into a ciliated bristle. Flagella more than twice the length of body. Third maxillipedes, when extended, reach a little farther than extremity of rostrum; the three distal segments about equal in length.

First pair pereiopods wanting in my specimen. Second pair slender, chelate, segments of equal length. Third pair of similar proportions to those in $S$. hispidus; chelæ $7 \mathrm{~mm}$. long; propodos laterally compressed and somewhat triangular in cross section, broad above; on the dorsal margin a double row of eleven spines each, on the ventral margin a single row of nine spines; two or three rows of minute spines on lateral surfaces. A number of long soft hairs over the fingers, especially at the tips. Hands of the two chelapods similar in size. Carpus and ischium together about equal to propodos, each armed with rows of spines. Fourth pair long and slender; dactylus bifid; propodos slightly spiny, one-half length of carpus. Carpus and propodos obscurely articulated. Fifth pair pereiopods undeveloped. Pleopods biramous, except first, with two or three spines each on the protopodite.

From the single specimen at my disposal I would compare this species with $S$. hispidus as follows: rostrum proportionately longer, nearly one-half length of cephalo-thorax, in n. sp. ( $\frac{1}{3}$ in hispidus), longer than peduncle of inner antennæ. Six ventral teeth (hispidus none), no lateral teeth, single dorsal row of ten teeth (hispidus six). Flagella of outer antennæ fully twice the length of body; proportion $2: x$ for n. sp., 7:5 for hispidus. Tergum of third abdominal segment with shield-shaped area. Third maxillipedes proportionately shorter than 
in hispidus. Spines on cephalo-thorax equally long, but less rigid than in hispidus, giving in general a less thorny character to the new species.

\section{EUCIPHIDEA}

\section{Family Palæmonidæ Bate}

\section{Palæmon savignyi Bate}

Brachycarpus savignyi Bate, Challenger, Macrura, p. 795, Pl. I29, fig. 4, I888.

Ortmann, Zoöl. Jahrb., Bd. V, p. 727.

(a) I specimen. Near Nassau, N.P., Feb., I8go.

(b) I specimen. Nassau, N.P., I890.

(c) $5 \&$ with ova. Nassau, N.P., I8go.

Bate's specimen was from Bermuda, "in shallow water."

"This is the most northern limit of genus Palæmon." Ortmann.

The species has not been described from any other localities.

\section{Leander northropi n. sp. (Pl. xxx, Fig. 4)}

(a) I specimen. Nassau, N.P., Jan., I8go.

A single specimen with a total length of $30 \mathrm{~mm}$. Length of cephalothorax to tip of rostrum II. $5 \mathrm{~mm}$.

Cephalo-thorax with small tooth below orbit and a very minute tooth below this and a little back from the anterior margin on the lateral surface.

Length of rostrum to posterior end of orbit $7 \mathrm{~mm}$., slightly curved upwards toward apex. Ten teeth above, four below; the first dorsal tooth forms with the tip of rostrum a bifid extremity. A long interval between first and second tooth; interval between second and third onethird the length of that between first and second; fourth, fifth, and sixth teeth follow at slightly diminishing intervals, the sixth being over the posterior part of orbit of eye. Seventh, eighth, and winth teeth close together, posterior to orbit of eye.

The first ventral tooth is a little in front of second dorsal, second ventral below second dorsal; third and fourth at equal intervals between second ventral and orbit of eye.

Inner antennæ: peduncle reaches beyond second ventral tooth of rostrum; proximal segment about equal to the two distal. Upper flagellum bifid; united proximal portion of $\mathrm{I} 4$ segments; the shorter branch 
has I2 segments; united therefore for more than half its length. The longer branch reaches beyond the undivided flagellum.

Outer antennæ: scaphocerite with lamellar portion slightly longer than spinose, reaches beyond first ventral tooth of rostrum; flagellum exceeds the length of the body.

Third pair maxillipedes reach to end of peduncle of inner antennæ.

First and second pereiopods: long, slender, and chelate; second longer than first; chela in second as long as carpus. Third and fourth pereiopods terminate in claws.

Pleopods biramous, setose. Telson lanceolate, $4 \mathrm{~mm}$. long, noticeably shorter than uropods, distal extremity with two sharp spines. Outer uropod imperfectly divided transversely, the proximal division ending in a lateral spine.

This species is allied to L. petitinga F. Müller, from Brazil (see Ortmann, Revista do Museu Paulista, II, p. I9I, I897) and to $L$. maculatus Thallwitz (Abh. Mus. Dresd., III, p. I9, I89I) from West Africa.

I am indebted to Dr. Ortmann for the preparation of the following table, which exhibits the relationship:

\begin{tabular}{|c|c|c|c|}
\hline & L. maculatus & L. northropi & L. petitinga \\
\hline Inner antennæ & $\left\{\begin{array}{l}\text { I2-I3 segments united } \\
8 \text { segments free. }\end{array}\right.$ & $\left\{\begin{array}{l}\text { I4 segments united } \\
\text { I2 segments free. }\end{array}\right.$ & $\left\{\begin{array}{l}9 \text { segments united } \\
20 \text { segments free. }\end{array}\right.$ \\
\hline 年 & $\frac{6+I}{3}\left\{\begin{array}{l}\text { I posterior to } \\
\text { orbit. }\end{array}\right.$ & $\frac{9+1}{4}\left\{\begin{array}{c}4 \text { posterior } \\
\text { to orbit. }\end{array}\right.$ & $\frac{6+\bar{I}}{5-6}\left\{\begin{array}{l}\text { I posterior } \\
\text { to orbit. }\end{array}\right.$ \\
\hline
\end{tabular}

\section{Family Hippolytidæ Ortmann}

\section{Tozeuma carolinense Kingsley}

Kingsley, Proc. Acad. Nat. Sci. Phila., p. 90, I878.

(a) I $q$, with ova. Dredged in about I6 ft. Near Quarantine station, Jan., I89o.

Kingsley's specimens are from Ft. Macon and Beaufort, N.C., and Charlotte Harbor, Fla.

Measurements of Bahama specimen: total length 4I mm., rostrum I2 mm., cephalo-thorax (without rostrum) $7 \mathrm{~mm}$., abdomen $22 \mathrm{~mm}$. 
Family Alpheidæ Bate

\section{Alpheus edwardsii Audouin}

Athanas edwardsii Audouin, Planches de la descrip. de l'Egypte par M. Savigny, Crust., Pl. X, fig. II, I8Io.

Bate, Challenger, Macrura, p. 542, I888.

(a) 4 specimens. Near Nassau, N.P., along shore, Feb. 20, I89o.

(b) I specimen. Nassau, N.P., Jan., I89o,

(c) 3 specimens. Under coral and in pools between tides, New Providence.

(d) I specimen. Under coral and in pools between tides, Nassau, N.P., Jan., I890.

(e) 2 broken. Near Nassau, N.P., Feb., I8go.

The distribution of this species is circumtropical.

\section{Alpheus hippothoë De Man}

bahamensis, n. var. (Pl. xxx, Fig. 5)

(a) 24 specimens. Under coral and in pools between tides, New Providence.

(b) 3 specimens, one with ova. Nassau, N.P., Jan., I8go.

(c) 2 specimens, one with ova.

This species is most closely allied to the variety edamensis of Alpheus hippothoë De Man, from the Bay of Bengal and Indian Archipelago (Arch. de Naturg., Bd. 53, p. 518, I887). I am indebted to Dr. Ortmann for a communication from Professor de Man comparing specimens from my material with his own hippothoë. As there are certain differences between the West and East Indian specimens, I propose to make a new variety for the West Indian.

Total length from rostrum to telson, largest $24 \mathrm{~mm}$., smallest I5 mm. Rostrum reaches nearly to end of first segment of inner antenna, sharp, laterally compressed, prolonged backwards as a distinct keel. Between keel and the prominent eyes a rounded depression. No ocular spines.

Inner antennæ: first joint of peduncle with small spine on outer surface; second joint nearly twice the length of proximal; terminal joint one-half the length of second. Shorter flagellum, about the length of peduncle. Longer flagellum slender, about thrice the length of shorter. 
Outer antennæ: peduncle a little longer than that of inner, small spine on basal joint. Flagellum one-third longer than long ramus of inner antenna, spinose portion of scaphocerite a little longer than the peduncle. Flabellar portion (scale) a trifle shorter; not quite so long as the peduncle.

Third pair of maxillipedes do not reach beyond end of peduncle of the outer antennæ.

First pair pereiopods: large chela of largest specimen has a length of $18 \mathrm{~mm}$., of smallest specimen $8 \mathrm{~mm}$. The large chela has a somewhat quadrangular depression on the outer surface, the distal end of which is continued upwards into a well-marked depression on the dorsal margin and extends backward as a groove along the inside of the dorsal surface. A distinct but less marked depression on the ventral margin. Inner surface of the hand slightly hairy, outer surface nearly smooth. Fingers contorted, color in alcoholic material pale blue. Movable finger slightly longer than thumb. In the small chelapod, which may be on the right or left side, the finger is one-third the length of palm. Carpus of chelapods short. Meros triangular in section; ends distally in a sharp spine on the outer and inner angle. Distal end of meros reaches to end of peduncle of outer antennæ.

Second pair of pereiopods very long. Distal end of meros reaches beyond antennal peduncle. First and second joints of carpus subequal, each a little longer than third and fourth together. Third and fourth subequal. Fifth about two-thirds length of first; equal in length to fourth and fifth together. Finger about one-half length of thumb. (Fifth joint a little too short in figure.)

Third and fourth pereiopods short and stout, not quite reaching to distal end of meros of second. Length of meros less than three times its breadth. Carpus one-half length of meros. Both carpus and meros, with spines on lower margin of distal end. Propodos serrated on posterior surface.

Fifth pair of pereiopods shorter and more slender. Telson with median furrow. Two small spines on either side of furrow. Outer plate of uropod minutely serrated on end. A sharp spine on its outer distal angle.

Principal variations from $A$. hippothoë.:

In new variety: peduncle of outer antennæ longer than that of 
inner. Lamellar portion does not reach end of peduncle. Third maxillipedes do not reach beyond antennal peduncle. Relative lengths of carpal joints of second pereiopods differ.

Variations from var. edamensis:

Finger of small hand shorter than palm (longer in edamensis). A quadrangular rather than a triangular depression on side of large hand.

First joint of carpus of second pereiopod is equal in length to second (shorter in edamensis). Third and fourth pereiopods less broad than in edamensis.

\section{Alpheus Websteri Kingsley}

Kingsley, Proc. Acad. Nat. Sci. Phila., p. 416, I879.

(a) 3 specimens, one with ova. Along shore, near Nassau, N.P., Feb. 20, I89o.

(b) 2 specimens, one with ova. Nassau, N.P., Jan. Io, I89o.

(c) 3 specimens, fragmentary. Nassau, N.P., Jan. Io, I89o.

Kingsley's type specimens were from Key West; it has been reported by Herrick from Nassau, N.P.

$A$. Websteri is very probably the same as $A$. formosus Gibbes (Proc. Am. Ass. Ad. Sci.; p. I96, I850). The descriptions apparently tally, though Gibbes makes no mention of the small black spine on the uropod which is mentioned as a characteristic feature by Kingsley, and which is very evident in my specimens.

\section{Alpheus nigro-spinatus n. sp. (Pl. xxx, Fig. 6)}

(a) 2 specimens. Under coral and in pools between tides, New Providence.

Carapace compressed. Rostrum short, acuminate, no longer than spines of ocular hoods; extended backwards as a ridge between the eyes, from each of which it is separated by a rounded depression. Spines of ocular hoods short, acuminate. The front of carapace is thus marked by three, nearly equal, small spines. Inner antennæ: basal segment of peduncle with small spine (stylocerite); second and third segments, no spines but scattered hairs; second segment a little more than twice as long as the terminal; outer flagellum stouter and shorter than the inner. Outer antennæ: outer angle of the basal joint of peduncle with a sharp short spine; scaphocerite broad at 
base, outer margin produced into a strong spine which is longer than the inner, lamellar, portion; distal end of terminal segment of peduncle reaches to tip of scaphocerite. Third pair of maxillipedes reach about to the end of shorter flagellum of inner antennie; strongly tufted with hair.

First pair of pereiopods: larger hand much inflated, a slight but distinct constriction on the upper margin near the articulation of the dactylus, and a deep constriction on the lower margin. Thumb contorted; a groove on the outer margin, the inner surface thickly covered with hairs and punctate. Dactylus contorted; extends slightly beyond thumb; inner surface with tufts of hair. Small hand (which on the one specimen is left, the other right) has a longer and more slender dactylus and thumb. Length of large hand I6 mm., breadth $6.5 \mathrm{~mm}$. Length of small hand $9 \mathrm{~mm}$., breadth $4 \mathrm{~mm}$.

Second pair of pereiopods : carpus five-jointed, proximal segment the longest, slightly longer than the second and third together; second and fifth segments each a little longer than one-half the length of first; third and fourth the shortest, subequal. Posterior pereiopods: meros without spines. Telson broadly triangular; extremity truncate; two small spines on either side of median line of dorsal surface; the outer ramus of uropod bears on its external distal angle a large, very black spine, which is distinguished from the similar black spine of $A$. Websteri Kingsley (1.c., p. 416, I879) by its much larger size and consequently more prominent appearance. Length of specimens $25 \mathrm{~mm}$. and $22 \mathrm{~mm}$. respectively.

\section{Alpheus minor Say}

Say, Jour. Acad. Nat. Sci. Phil., I, p. 245, I818.

Kingsley, Bull. U. S. Geol. Survey, IV, p. I90, I878.

Bate, Challenger, Macrura, p. 558, Pl. C., I888.

(a) numerous specimens, from brown sponges.

(b) I $\&$, with ova. Along shore near Nassau, N.P., Feb. 20, I89o.

(c) Io specimens, from brown sponges.

Range: From Cape Hatteras (U.S.F.C. I885) to St. Paul's Rock (Bate, Challenger). Both shores of Central America.

Collected at Jamaica, New Providence.

Lot $(c)$ may possibly be a variety, as the thumb is shorter than the typical minor, but otherwise there seems no difference. 


\section{6r. Alpheus saulcyi Guérin}

Guérin, in Hist. du Cuba, 1857.

Herrick, Memoirs Nat. Acad. Sci., Vol. V, p. $38 \mathrm{I}$.

(a) 5 specimens, from green sponges, Feb., I89o.

(b) I specimen, near Nassau, Feb. 5, ז89o.

(c) I specimen, $\hat{\jmath}$, from green sponge.

(d) I specimen, from sponge, March I, I8go.

(e) I specimen, from sponge, March $\Upsilon$, I8go.

$(f) 2$ specimens, Nassau, N.P., Jan., I8go.

Range: West Indies.

Found at Nassau, Martinique.

\section{Athanas ortmanni n. sp. (Pl. xxx, Fig. 7)}

(a) I specimen. Along shore, near Nassau, N.P., Feb. 20, I8go.

Rostrum slender and pointed, reaching a little beyond the second joint of peduncle of inner antennæ. Antero-lateral margin of carapace extends obliquely backward, prolonged in front of eye into minute spine. Eye-stalk short, not projecting beyond carapace. The eye is seen through the somewhat transparent carapace as in Alpheus. Inner antennæ, with stylocerite reaching to distal end of second segment of peduncle. From the peduncle arise two flagella of nearly equal length, the upper somewhat more slender than the lower, bearing on the fourth segment from base a minute, subsidiary flagellum.

Outer antennæ with scaphocerite nearly as long as the peduncles of inner antennæ, broad and fringed with hairs. Third pair of maxillipedes reach slightly beyond the distal end of scaphocerite.

First pair of pereiopods: that on the right side is robust with swollen chela, terminating in slender hooked fingers which are minutely serrated on the opposing edges. Margin of chela entire, length $5 \mathrm{~mm}$., breadth $2.5 \mathrm{~mm}$. Carpus short. Distal end of meros reaches to extremity of third pair maxillipedes. Left chelapod lacking.

Second pair of pereiopods slender, with very small chelæ. Carpus five-jointed; proximal segment equal in length to the four distal segments. Remaining three pairs of pereiopods similar to each other and equal in length to the second pair: Pleopods narrow and biramous. Telson narrow and compressed, with smooth margins. Uropods slightly longer than telson. 
Total length of specimen $16 \mathrm{~mm}$.

The species above described agrees generically with Athanas Leach (Edin. Ency., VIII, p. 432), with the exception that the eyes are entirely covered by the carapace. I propose, rather than found a new genus on the single specimen, to amend Leach's definition of Athanas by changing the statement, "Opthalmopoda short, scarcely reaching beyond frontal margin of carapace" (Bate, Challenger, Macrura, p. 528), to opthalmopoda short, covered by, or scarcely reaching beyond the frontal margin of carapace.

There are four hitherto described species of Athanas:-

A. nitiscens Leach. England and Norway, Mediterranean to Cape Verde Islands.

A. veloculus Bate (l.c., p. 529). Cape Verde Islands.

A. mascarenicus Richters (Beitrage zur Merresfauna von Mauritius u. d. Seychellen, p. I64, I880), Mauritius.

A. dimorphus Ortmann, Crust. in Semon's Forschungsreise (Jena. Denks., VIII, I894, p. ז2). East Africa: Dar-es-Salaam.

From all these species $A$. ortmanni may be distinguished at a glance by the form of the large chela.

PEN AIDEA

Family Penæidæ Bate

63. Penæus constrictus Stimpson

Stimpson, Ann. Lyc. Nat. Hist: N.Y., p. 135, I87I.

Miers, Notes on the Penæidæ, Proc. Zoöl. Soc., London, p. 308, I878.

(a) I t. Near Nassau, N.P., Feb. I, I89o.

(b) I \&. Nassau, N.P., Feb. 5, I89o.

Range: East coast United States.

Not before reported from West Indies.

Collected by Stimpson at Beaufort, and Charleston, S.C.

\section{STOMATOPODA}

Family Squillidæ Latreille

64. Pseudosquilla ciliata Miers

Miers, Ann. and Mag. Nat. Hist. (5) V, p. ro8, Pl. III, figs. 7 and 8, I880. 
Brooks, Challenger, Stomatopoda, p. 53, I886.

(a) I oै, broken. Near Nassau, N.P., Feb., I89o.

Range: Widely distributed over Atlantic and Pacific.

Collected at Cuba, Bahamas, St. Thomas.

\section{Gonodactylus œrstedii Hansen}

Hansen, Isopoden, Cumaceen und Stomatopoden der Plankton expedition, I895.

(a) I ㅇ․ Nassau, N.P., Feb. 5, I8go.

(b) I 9 , fragmentary. Quarantine station, near New Providence, Jan. 25, I89o.

(c) I 9. Along shore near Nassau, N.P., Feb. 20, I8go.

(d) I \%. Nassau, N.P., Jan., I89o.

(e) I $\delta$, I 9 , I fragmentary. Under coral and in pools between tides, near Nassau, N.P.

$(f)$ I $\hat{o} . \quad$ (label erased).

(g) 2 juv. Dredged in about $16 \mathrm{ft}$. near Quarantine station, Jan., I89o.

Hansen, I.c. supra, p. 65 (and footnote), calls the West Indian Gonodactylus: $G$. cerstedii n. sp. and retains the name G. chiragra Fabr. for the East Indian form.

He says (footnote): "This species (arstedii) may be distinguished from the East Indian form, G. chiragra Fabr., especially by the character, that it possesses a small keel inside of and close to the keel that ends in the sublateral process of the posterior margin, while such a secondary keel is wanting in the Indo-Australian species."

Collected at Bahamas, Cuba, Jamaica, St. Thomas.

\section{CIRRIPEDEA}

\section{Family Lepadidæ Darwin}

\section{Lithotrya dorsalis Sowerby}

Sowerby, Genera of shells, April, I822.

Darwin, A Monograph of the Cirripedia, p. 35I, Pl. VIII, fig. I, a, I851.

(a) Io specimens. Salt Cay, N.P., in rocks in surf, Jan. $28,1890$.

(b) 8 specimens. Salt Cay, Nassau, N.P., ocean side, Feb. 6, I89o. 
Range: West Indies, Venezuela, Honduras.

Collected at Barbadoes.

\section{Family Balanidæ Darwin \\ 67. Acasta cyathus Darwin}

Darwin, A Monograph of the Cirripedia-Balanidæ, p. $3^{\text {I2 }}$ Pl. IX, I854.

(a) 4 specimens, in sponge. Dredged Jan. 22, I8go.

(b) 2 specimens. Near Nassau, N.P., Feb., I8go.

Range: Madeira, West Indies (Darwin).

\section{ISOPODA}

Two species of Isopoda, one probably a Lygia of which there are several specimens. Another parasitic on a fish, probably one of the Cirolanide.

\section{AMPHIPODA}

Several small amphipods undetermined. 


\section{PLATE XXIX}

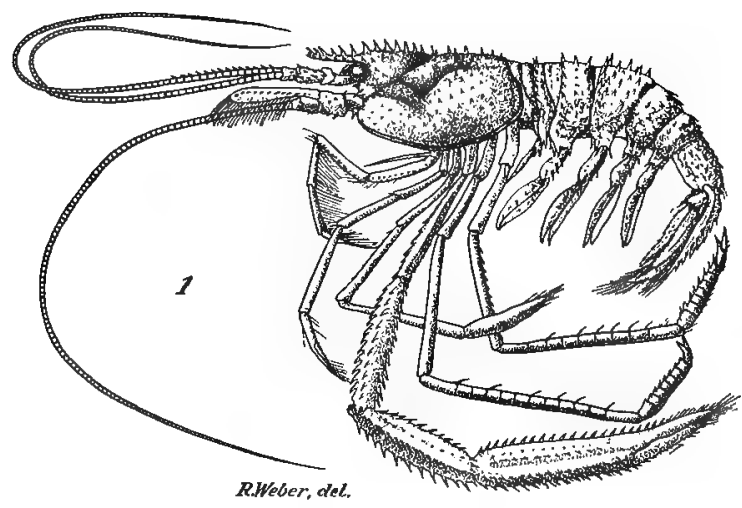

FIG. I. - Stenopus hispidus Latreille.

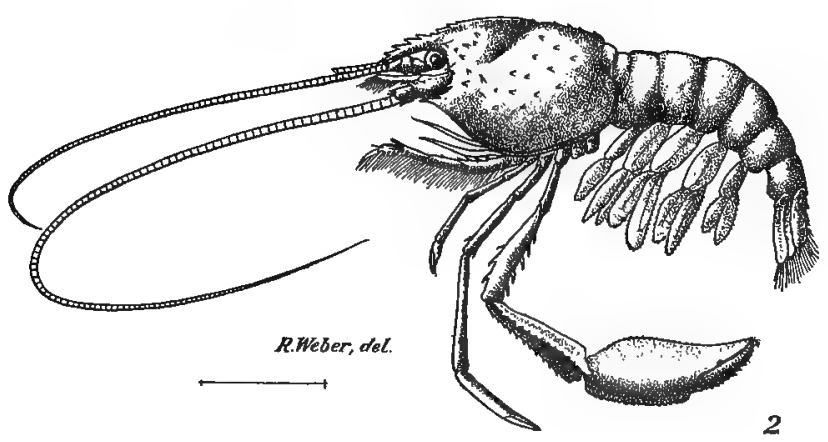

FIG. z. - Stenopus semilævis Von Martens.

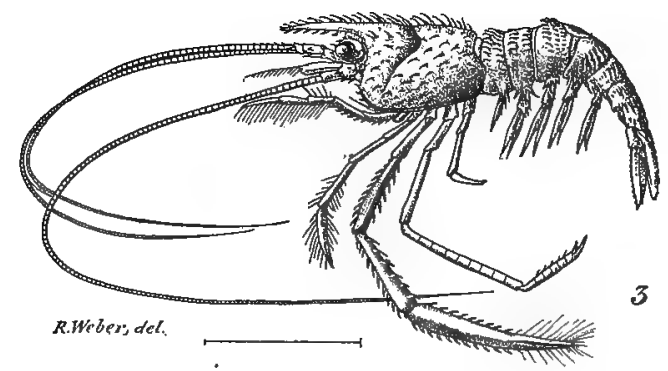

FIG. 3. - Stenopus scutellatus, n. sp. Rankin. 


\section{PLATE XXX}

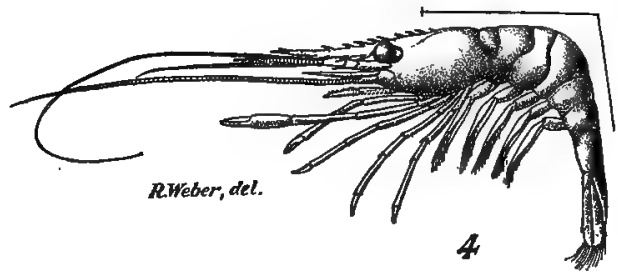

FIG. 4. - Leander northropi, I. sp., Rankin.

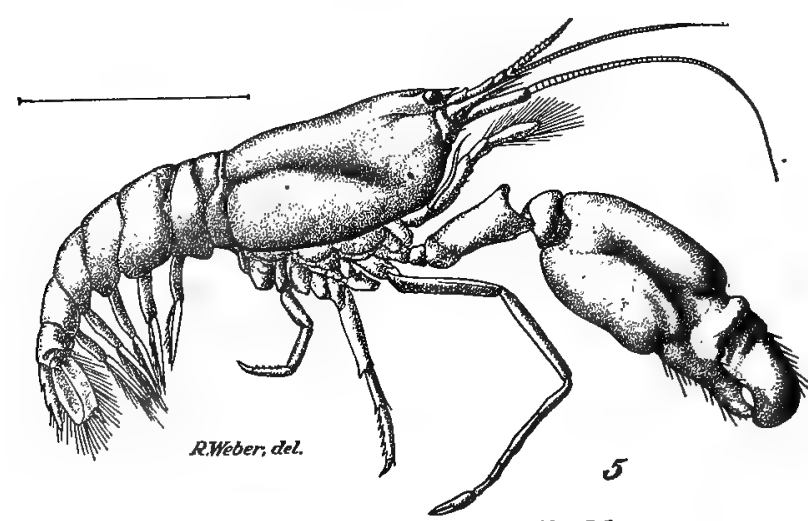

FIG. 5. - Alpheus hippothö De Man. var. bahamensis, n. var., Rankin.

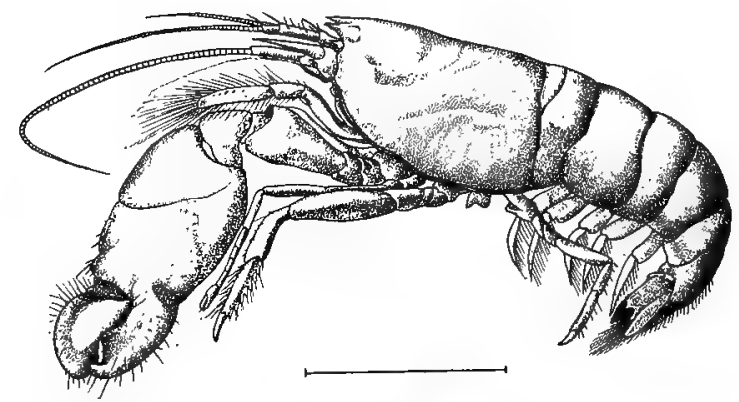

FIG. 6. - Alpheus nigro-spinatus, «. sp., Rankin.

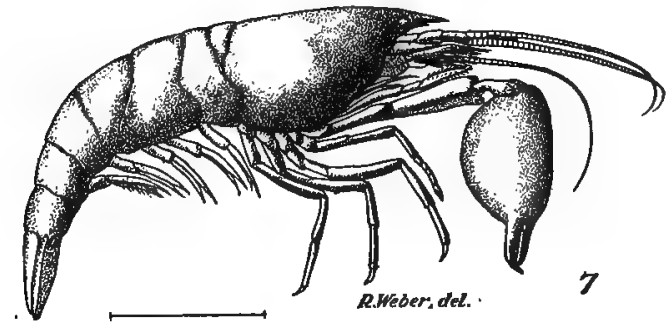

FIG. 7. - Athanas ortmanni, n. sp., Rankin. 


\section{LIST OF SHELLS COLLECTED BY DR. JOHN I. NORTHROP IN THE BAHAMAS, IDENTIFIED BY PROFESSOR WILLIAM HEALEY DALL, SMITHSONIAN INSTITUTION}

THE following list was made from Dr. Northrop's specimens which were sent to the National Museum for the purpose. So many shells have been collected at the Bahamas during the last two hundred years that the fauna is fairly well known, and it was not to be expected that any very remarkable additions to it could be made on such a collecting trip. Well-identified species, however, always have a certain value for science, in their bearing on geographical distribution, as the localities given by the earlier collectors were often vague or inaccurate.

That Cyrena floridana and Macroceramus pontificus should occur was interesting, and a number of the other species, though known to belong to the general region, had not heretofore been specifically located in the Bahamas.

The shell identified as Mitra flammea is bleached and worn, and may be another species. It is not, however, any of those commonly known as Antillean.

\section{PELECYPODA}

138. Arca occidentalis Philippi. Deep Creek, Andros.

103. Arca fusca Brug. Salt Cay.

35. Arca jamaicensis $\mathrm{Gm}$. Lake Cunningham, N. P.

39. 210.* Glycymeris undulata Lam. Salt Cay.

I6. Pinna carnea $\mathrm{Gm}$. Nassau.

92. Melina obliqua Lam? Salt Cay.

46. Melina ephippium Linn. Salt Cay.

I34. Pteria atlantica Linn. Deep Creek, Andros.

59. Margaritiphora radiata Leach. Salt Cay.

136. Ostrea frons Linn. Deep Creek, Andros.

65. Pecten ornatus Lam. Salt Cay.

60; ז37. Spondylus spathuliferus Sby. Salt Cay and Deep Creek, Andros.

I23. Lima scabra Born. Nassau.

I04. Lithophaga antillarum Phil. Salt Cay.

102; I30; 224. Mytilus exustus Linn. Salt Cay. 
I5I. Cyrena colorata Prime. Cedar Coppet, west side of Andros.

125. Cyrena floridana Con. Low Sound, north end of Andros.

72 ; I29. Chama macerophylla Chemn. Salt Cay, N.P., and Deep Creek, east side of Andros.

76. Chama sarda Rve. Salt Cay.

44. Phacoides pensylvanicus Linn. Salt Cay.

48. Codakia Linn. Beach near Nassau.

66. Divaricella quadrisulcata Orb. Salt Cay.

51; 96. Cardium serratum Linn. Salt Cay.

40; 222. Cardium medium Linn. Salt Cay.

43. Cardium isocardia Linn. Salt Cay.

99. Anomalocardia cuneimeris Conr. Salt Cay.

I28; I33. Chione cancellata Gm. Wide Opening, west side of Andros and Deep Creek, Andros.

41. Chione paphia Linn. Salt Cay.

17. Asaphis deflorata Linn. Near Deep Creek, Andros.

74. Tellina fausta Don. Salt Cay.

46a. Tellina interrupta Wood. Beach near Nassau.

45. Tellina magna Spengl. Salt Cay.

75. Semele reticulata $\mathrm{Gm}$. Nassau.

\section{TERRESTRIAL GASTROPODA}

I2I. Polygyra cereolus Muhl. Red Bays, west side of Andros.

II9. Cepolis albersiana Pfr. Red Bays, west side of Andros.

122. Cepolis Duclosiana Fer. Red Bays, west side of Andros.

II8. Cepolis varians Mke. Red Bays, west side of Andros.

I20. Cepolis troscheli Pfr. Red Bays, west side of Andros.

18; 80. Pleurodonte auricoma Fer. Nassau.

228.* Orthalicus undatus Brug.

II2. Tralia pusilla Gm. Salt Cay.

I55. Melampus bidentatus Say. Cedar Coppet, west side of Andros.

$62 ; 223$ * Melampus coffeus Linn. Salt Cay.

28. Opisthosiphon Bahamense. Nassau.

2. Cerion (Strophiops) Sagraianum Pfr.

I83-184. Cerion (Strophiops) glans Küster., and var.

I19. Cerion (Strophiops) inflatum Mayn.

3. Cerion (Strophiops) glans, var. cinerea Mayn.

4. Cerion (Strophiops) cyclostomum Küster.

5. Cerion (Strophiops) lentiginosum Mayn.

6; 7; 8. Cerion (Strophiops) maritimum Pfr.

\section{MARINE GASTROPODA}

I50. Bullaria striata Brug. Cedar Coppet, west side of Andros.

58. Bullaria occidentalis A. Ad. Salt Cay. 
53. Terebra casta Hds. Salt Cay.

I57a. Terebra protexta Con. Cedar Coppet, west side of Andros.

6. Conus mus Hwass. Salt Cay.

4; I05a. Thais patula Linn. (operculum). Beach near Nassau. Salt Cay.

9I. Thais hamastoma Linn. Salt Cay.

47. Thais delioidea Lam. Salt Cay.

85. Leucozonia ocellata Gm. Salt Cay.

85a. Leucozonia leucozonalis Lam. Salt Cay.

9. Turbinella scolymus $\mathrm{Gm}$. Nassau.

8. Fasciolaria tulipa Linn. Nassau.

I. Oliva reticularis Lam. Nichol's Town, Andros.

36; 95. Columbella mercatoria Linn. Salt Cay.

63. Nitidella nitida Lam. Salt Cay.

94. Mitra Barbadensis Gm. Salt Cay.

I62. Mitra flammea Quoy.? Salt Cay.

r2. Marginella guttata Dill. Near Nichol's Town, Andros.

II3. Marginella lactea Kiener. Salt Cay.

I24. Marginella apicina Mke. Low Sound, north end of Andros.

154. Marginella apicina Mke.? Cedar Coppet, west side of Andros.

89. Cymatium pileare Linn. (juv.). Salt Cay.

III. Septa tritonis L., var. nobilis Con. Stafford Creek, Andros.

22. Cassis testiculus Linn. Salt Cay.

21. Cassis inflata Shaw. Salt Cay.

105. Morum oniscus Linn. Salt Cay.

I10. Tonna perdix Linn. Nichol's Town, Andros.

3c* Cyphoma gibbosa Linn.

3. Cyprca spurca Linn.? Salt Cay.

3a. Cyprea cinerea Linn. Salt Cay.

7. Cypraa exanthema Linn. Mastic Point, Andros.

64. Trivia pediculus Linn. Salt Cay.

31. Cerithidea costata Wood. Border of pond, Salt Cay, near Nassau.

162a. Cerithium literatum Born. Salt Cay.

157. Cerithium uncinatum Gm.? Cedar Coppet, west side of Andros.

I27. Vermetus radicula Stimp. Wide Opening, west side of Andros.

55; 126. Littorina angulifera Lam. Mangroves, Mastic Point, Andros and Nassau.

25. Littorina ziczac Dillw. Tide pools, Nassau.

30. Littorina mespilum Mke. Tide pools, Salt Cay.

ro7; II6. Tectarius muricatus Linn. Nassau; Salt Cay.

49; II7. Echinella nodulosa Pfr. High tide, Nassau.

87. Hipponix antiquatus Linn. Salt Cay.

I3; $32 ; 69 ;$ r49. Natica canrena Linn. Near Nichol's Town, Andros; Salt

Cay, Nassau; Cedar Coppet, west side of Andros.

24. Acmcea melanoleuca $\mathrm{Gm}$. Rocks between tides, Nassau.

67. Acmcea puncturata Lam. Salt Cay. 


\section{LIST OF SHELLS COLLECTED IN THE BAHAMAS}

15. Astraa calata Chemn. Cays near Nassau.

8I; 227.* Astraa longispina Lam. Salt Cay.

93. Tegula scalaris Anton. Salt Cay.

ror. Tegula fasciata Born. Salt Cay.

Io; 208.* Livona pica Gm. Nassau.

68; 2I7.* Nerita tessellata Gm. Tide pools, Salt Cay.

2I2.* Nerita versicolor Lam.

213.* Nerita peloronta Linn.

I64. Neritina virginea Linn. Andros (?).

29. Neritina pupa Linn. Tide pools, Salt Cay.

88. Fissurella alternata Say. Salt Cay.

2. Fissurella Listeri Orb. Salt Cay.

2a. Fissurella Barbadensis Gm. Salt Cay.

\section{CEPHALOPODA}

37. Spirula australis Lam. Gulfweed on beach, Nassau.

N.B. - The numbers with an asterisk had no localities given for them. 


\section{NOTES ON SOME ACTINIANS FROM THE BAHAMA ISLANDS, COLLECTED BY THE LATE DR. J. I. NORTHROP ${ }^{1}$}

By J. Playfair McMurrich, Ph.D.

(Read April Ir, I8g6.)

THE Actinians which form the subject of this paper were collected by the late Dr. J. I. Northrop, of Columbia College, during a visit to the Bahama Islands some years ago. It had been Dr. Northrop's intention to work over the collection himself. Before his lamented death he had studied several species more or less thoroughly. The drawings and preparations which he had made were intrusted to me, together with the collection, by Mrs. Northrop, and have proved of great assistance in determining the affinities of certain forms. Especially was this true in regard to Heteractis lucida, whose systematic position Dr. Northrop had correctly determined, and the notes on Diplactis bermudensis and Isaurus duchassaingi were also very full.

I have taken pains to verify all the important facts contained in the notes, and it has seemed more convenient for the present purpose to describe in my own words the various forms to be considered, rather than to attempt a rearrangement of Dr. Northrop's notes with such additions as might seem necessary.

The following is a list of the species in the collection.

\section{HEXACTINIF}

Suborder Actininz

Family SAGARTIDE

I. Aiptasia tagetes (Duch. \& Mich.) Andr.

2. Heteraciis lucida Duch. \& Mich.

Family ANTHEAD $\approx$

3. Condylactis passiflora Duch. \& Mich.

${ }^{1}$ Annals N. Y. Acad. Sci., Vol. IX, July, I896. - r3. 


\section{Family DENDROMELID $Æ$}

4. Lebrunea neglecta Duch. \& Mich.

Family PHYLLACTID $Æ$

5. Diplactis bermudensis McMurr.

\section{Suborder Stichodactylinæ}

Family DISCOSOMID $Æ$

6. Discosoma anemone (Ellis) Duch.

Family RHODACTIDÆ

7. Rhodactis sancti-thoma (Duch. \& Mich.) McMurr.

8. Ricordea florida Duch. \& Mich.

\section{Family PHYMANTHIDA}

9: Phymanthus crucifer (Lesueur) Andres.

\section{ZOANTHE $\mathbb{E}$}

10. Zoanthus sociatus (Ells) Lesueur.

II. Zoanthus nymphaus Lesueur.

I2. Isaurus duchassaingi Andres.

I3. Palythoa flava (Lesueur) Duch. \& Mich.

I4. Gemmaria isolata McM.

Certain of these forms I have already described ('89), and consequently shall not consider in detail here; a few others require but brief notice, while three others require a more thorough description. I shall consider the forms belonging to the last two groups in the order in which they are named in the above list.

\section{Family SAGARTID压}

Heteractis lucida Duch. \& Mich.

Synonyms: Capnea lucida Duch. \& Mich. I860 (Pl. VI, Figs. 9 and I2). Heteractis lucida Duch. \& Mich. 1866.

Ragactis lucida Andres. I883.

Several specimens of this form were contained in the collection which offered accordingly opportunities for an accurate determination of its systematic affinities. 
In the contracted condition the animal is generally somewhat flattened, measuring in height $1.5-2.0 \mathrm{~cm}$, and in diameter about $2 \mathrm{~cm}$., the base being usually a little smaller than the upper part of the column. Dr. Northrop's notes contain no statement as to the coloration of the living animal, but according to Duchassaing and Michelotti the mouth is white, surrounded by a band of brilliant yellow, and the tentacles have the appearance of white glass.

The mesoglœa of the column walls is rather thin, and in much contracted forms may appear as if provided on its endodermal side with numerous distinct processes, which give to the column wall a ridged or checkered appearance. Toward the upper part of the column are numerous cinclides, not readily distinguishable in all preserved specimens and apparently without any very definite arrangements, though they are confined entirely to the upper part of the column, none being found below the middle.

There is a distinct collar and fosse in the preserved specimens just above the cinclidal region of the column, and at that portion of the wall which forms the floor of the fosse the endodermal muscle processes are considerably higher than elsewhere in the column wall, and form what may be termed a diffuse endodermal sphincter. The true sphincter lies, however, higher up, just below the point where the tentacles arise, and is a weak structure embedded in the mesogloea, which is hardly appreciably thickened for its reception. It consists of a few rather scattered cavities, arranged practically in a single row and containing the remains of muscle cells; it is not strong enough to produce complete inclosure of the tentacles.

On account of the position of the sphincter the collar cannot be regarded as the margin. Indeed there is no distinct margin, the upper part of the column wall passing directly over into the bases of the tentacles, so that, in the usual formula, it is necessary to say that the margin is tentaculate. The tentacles are rather numerous, apparently somewhere in the neighborhood of I92, though an accurate count is difficult in the preserved specimens on account of the manner in which the cycles are crowded together towards the margin. They vary somewhat in length in the various specimens I have examined, owing to difference of contraction, but the average may be put at I $\mathrm{cm}$. The most interesting feature of the tentacles is, however, the occurrence upon them of a large number of spherical protuberances scattered over their sur- 
face without any apparent regularity, though more abundant upon the oral than on the aboral surfaces. In section (pl., fig. I) these are seen to be hollow outpushings of the wall of the tentacles. The wall of the tentacle proper has a moderately thick mesoglœa, the ectodermal and endodermal muscle processes being rather low, the ectoderm possessing but few nematocysts, and the endoderm being thin with only a few Zoöxanthellæ. The wall of the protrusion differs not a little from this; thus the mesoglœa is much thinner, the muscle processes are aborted, the ectoderm is richly provided with nematocysts, so that the protrusions might be termed batteries of nematocysts, and the endoderm is thick and abundantly packed with Zoöxanthellæ.

The tentacles leave exposed a considerable portion of the disk, perhaps about half its breadth, and this portion is smooth and slightly concave. Its mesoglœa is rather thin, and the muscle processes are but moderate in length. No muscle cells are inclosed within the mesoglœa. The mouth is not elevated above the disk, and is almost circular in the preserved specimens, the gonidial angles being but slightly marked.

In the single specimen in which I counted the mesenteries there were forty-eight pairs, a number which agrees with that found by Dr. Northrop in another specimen. Of these forty-eight pairs but six are perfect, forming the first cycle; the six pairs of the second cycle nearly equal the first cycle in size, but are imperfect; the twelve of the third cycle are considerably smaller, though still quite muscular; while the twenty-four pairs of the fourth cycle, though extending some distance in from the body wall, yet have their musculature but feebly developed. Two pairs of directives are present and are attached to a greater extent of the stomatodæum than are the other mesenteries of the first cycle. The longitudinal muscles are well developed and have in section the form represented in fig. 2. The parieto-basilar muscles are but feebly represented and do not require special description. Numerous acontia occur, a fact that was discovered by Dr. Northrop. None of the specimens examined possessed reproductive organs, so that nothing can be said regarding the distribution of these organs.

There seems to be no room for doubt but that this form is identical with that described by Duchassaing and Michelotti in their first paper ('60) as Capnea lucida though later ('66) assigned to the genus Heteractis, a genus established by Milne-Edwards for the reception of the Actinia aurora of Quoy and Gaimard. Andres ('83) has referred it to 
the genus Ragactis, which he established for a species, $R$. pulchra, discovered by him in the Mediterranean. The distinction between Ragactis and Heteractis concerns practically the tentacles only, the evaginations upon these structures being in the former genus small and appearing as tubercles, while in the latter they involve the entire circumference of the tentacle, which thus becomes moniliform. How far this distinction is valid can only be determined by further examination of the anatomy of the various species assigned to the two genera, and for the present it seems to me more convenient to retain for the species under discussion the name proposed by its sponsors.

An interesting fact which has developed from the examination of H. lucida is that it is unquestionably a Sagartid. The occurrence of acontia (to which my attention was first called by Dr. Northrop) and of cinclides, the existence of only six perfect mesenteries and the mesoglœal sphincter point indubitably to this relationship, and it will be interesting to know whether Ragactis pulchra and the other species assigned to the genus Heteractis are likewise Sagartids. Andres has grouped together in the family Heteractidæ several genera, e.g. in addition to the two already mentioned, Eloactis, Rhopalactis, and Stauractis. Of these, as I have already suggested ('93), the genus Eloactis, as judged by the species $E$. Mazeli, is probably with greater propriety referable to the family Halcampidæ, and I have now shown that one at least of the members of the genus Ragactis must also be transferred to another family. Families based upon mere external characters have no firm foundation, tentacles may vary enormously in shape, warts or tubercles may be absent or present within the limits of the same family, and cases like the present show, if proof be still wanting, that the criteria for a proper classification of the Actiniaria are to be obtained only by the careful study of the internal anatomy of the various forms.

We must add then, provisionally, to the genera included in the family Sagartidæ, the genus Heteractis, since one of the forms assigned to it has proved to be a typical Sagartid. Whether, however, the type species of the genus, $H$. aurora, will also prove to be a Sagartid, or whether it will be necessary to remove $H$. lucida from the genus Heteractis, remains to be determined. And furthermore the affinities of Ragactis pulchra must also be accurately studied before the proper generic term for $H$. lucida can be finally determined. 


\section{Family DENDROMELIDÆ}

In my earlier paper ('89) on West Indian Actiniaria I proposed a new subtribe Dendromelinæ for the reception of the peculiar form Lebrunea neglecta discovered by Duchassaing and Michelotti ('60) and proposed to place in it also the genus Ophiodiscus described by R. Hertwig ('82). Since that time I have come to the conclusion that I gave the group too high a mark and have suggested ('93) its reduction to a family of the subtribe Actininæ. With the two forms already mentioned it seems that a third should be associated, namely, the Hoplophoria coralligens described by $\mathrm{H}$. V. Wilson ('90), which, as I have already pointed out elsewhere ('93), seems to be identical with the Viatrix globulifera described by Duchassaing and Michelotti ('60).

\section{Lebrunea neglecta Duch. \& Mich. 1860}

A single specimen of this form was in the collection, and being unwilling to injure it, I have nothing to add to the description of the structure given in my earlier paper. It may be stated, however, that the number of pseudotentacles is in this individual six, just as they were in the other specimens examined; one, however, is considerably smaller than the others.

\section{Family PHYLLACTID $Æ$}

Diplactis bermudensis McMurrich. $\quad$ I889

This species I described (' $89 a$ ) originally from alcoholic specimens from the Bermudas and was pleased to find it represented in the present collection by several specimens, together with a drawing (here reproduced in pl. xvii, fig. 3 ) and a description of the living animal. I have nothing to add to my original account of the anatomical characteristics of the species, but am able to complete it by abstracting from Dr. Northrop's notes a description of the coloration and form of the living animal.

The column is chocolate-brown in color, and when the animal is expanded, has a greater diameter at the base and at the upper part than in the middle of its length, the upper part forming a slight parapet projecting above the level of the disk. The tentacles are brownish red in color and the disk rufous, that is to say, somewhat paler than the tentacles. The papillæ which represent the fronds Dr. Northrop 
apparently overlooked, inasmuch as they would be completely hidden by the expanded tentacles, and even in preserved specimens they are only to be found by careful examination. What their appearance and form may be in the living condition cannot therefore be stated here.

The occurrence of this species in the Bahamas as well as in the Bermudas suggests the possibility of its identity with one of the forms described by Duchassaing and Michelotti, and in studying their descriptions two species are found to be worthy of remark in this connection. The first of these is the Actinia aster mentioned by Ellis ('86) and described by him as having "a thick, fleshy, smooth, and almost cylindrical stem, ending abruptly at the top, which is provided with circular rows of tentacles." This description contains nothing that is particularly distinctive, but nevertheless Duchassaing and Michelotti ('66) have identified with it a form which they describe as about an inch in height and with the tentacles ringed with white and brown, while the body and disk are "colorês en rougeatre et en bleu très-clair." Taking this latter description as a guide for the identification of $A$. aster, it will be seen that while making the necessary allowances for the uncertainties which are associated with color descriptions, there is a certain vague approximation of the coloration to that of Diplactis bermudensis; nevertheless, the discrepancies are too great to allow of an identification of the two forms. Dr. Northrop's notes contains no statements as to variations in color of $D$. bermudensis, and until it is found that these exist and that they approximate the coloration described for $A$. aster, it seems better to consider the two forms distinct.

Another form also presents possibilities in this connection, viz. the Anemonia depressa of Duchassaing and Michelotti ('60), a form with a large disk yellowish in color, with tentacles shorter than the diameter of the disk, and tinted with shades of blue and reddish ("leurs nuances sont le bleu et le rougeatre"). A figure is given of the disk and tentacles of this form and might answer for those of $D$. bermudensis, and if the mention of "le bleu" were omitted, the color descriptions would correspond fairly well. Of the two possibilities I think the identity of Diplactis bermudensis with Anemonia depressa is the more probable one, but even here the uncertainty is too great to justify the identification without further evidence, and for the present it seems wiser to allow the name used here to stand. 


\section{Family RHODACTID $Æ$}

Ricordea florida Duch. and Mich. I860

Synonym: Heteranthus floridus (D. \& M.) McMurrich. 1889.

In my paper on the Bahama Actiniaria I described this form as a species of Klunzinger's genus Heteranthus, disregarding the name bestowed upon it by Duchassaing and Michelotti on the ground that the characters assigned to the genus by those authors were specific rather than generic, and therefore insufficient, while Klunzinger's definition of his genus was quite adequate. Although this criticism still seems to me to be just, yet, nevertheless, according to the strict laws of priority, Duchassaing and Michelotti's name is the one which should be employed, and I take this opportunity of correcting my error in the matter.

Attention may also be called to the probability of the genus Homactis established by Verrill ('69), being identical with Klunzinger's Heteranthus, so that it too has a claim prior to Heteranthus, the latter genus not having been established until $\mathrm{r} 877$. Ricordea is, however, prior to both, and therefore should supplant them.

\section{Family ZOANTHID $Æ$}

\section{Zoanthus nymphæus (Les.)}

Synonyms: Mammillifera nymphaa Lesueur. 18 I7.

Palyihoa nymphosa Dana. I849.

Palythoa (Mammothoa) nymphosa. Andres. 1883.

In 18 I7 Lesueur established the genus Mammillifera for the reception of two Zoanthids (which he named $M$. auricula and $M$. nymphaa), and characterized the genus as containing those forms which possess "a large cuticular expansion, serving as the base of numerous animals, which, when contracted, assume the form of mammæ." Andres ('83) unites this genus with Palythoa, making it a subgenus for which he proposes the name Mammothoa, but this is evidently an error, since he characterized the genus Palythoa as having sandy incrustations in the column walls, while Lesueur distinctly gives it to be understood that his species of Mammillifera have fleshy walls. Erdmann in ' 85 revived Lesueur's genus, though, as Haddon and Shackleton ('9I) have pointed out, it is questionable if the form he referred to the genus 
can be associated with Lesueur's type species, and it is interesting accordingly to have an account of the structure of one of Lesueur's species, in order that the true position of his genus may be determined.

Among the slides which Dr. Northrop had prepared I find a number of a Zoanthid which he had provisionally designated No. 3, and also a number of drawings of the same form, one of which was the figure of the group of individuals taken from preserved specimens (fig. 4). Unfortunately, in the material forwarded me there were no examples of this No. 3, but there were specimens of a form which the accompanying label stated to have been collected by Dr. E. A. Andrews at Green Turtle Cay, Bahama Islands. This form resembled in general appearance the drawing of No. 3, and preparations which I made of it demonstrated with certainty its identity with Dr. Northrop's No. 3 .

As regards its identity with Lesueur's $M$. nymphaa, there must necessarily be a certain amount of uncertainty. It agrees with the figure of $M$. auricula given in Lesueur's paper, and it answers the generic description; unfortunately, I find no memoranda of its coloration, and base the identification with nymphea, rather than with auricula, on the number of tentacles, which is about fifty, and which Lesueur states to be about fifty in the former species and from twentysix to thirty in the latter.

The individual polyps composing a colony are seated close together upon a cœnenchymatous expansion, and reach in preserved specimens a height of about $2-3.5 \mathrm{~mm}$., the measurement being taken from the point of attachment to the cœenenchyme. The diameter of the column is about 3 or $4 \mathrm{~mm}$. at the top, slightly less lower down, and the capitulum shows clearly a number of radiating ridges.

The column wall is smooth and without embedded particles of foreign matter. In structure it resembles closely what has been described for Zoanthus sociatus, the same large lacunar spaces occurring in the mesoglcea, while the ectoderm is enclosed within the outermost portion of the mesoglœa, being covered by a mesoglœal subcuticula, and by a cuticle, much more distinct in some specimens than in others. The sphincter muscle, which, for diagnostic purposes seems to be of great importance in the Zoantheæ, is double, the two parts being well marked off from one another. The arrangement is shown in fig. 5, and from this it will be seen that the upper portion of the sphincter is 
small, while the lower is of some length and in its upper part is composed of a few large cavities which occupy the entire thickness of the mesogloa, lower down the cavities becoming smaller, but being for the most part more or less circular. The figure will, however, give a better idea of its arrangement than many lines of description, and from it it will be seen that in the number and arrangement of the muscle cavities the sphincter differs from that of any other form which has hitherto been described, particularly from that of the form described by Hertwig ('88), as Z. Danee, the sphincter of which has been described by Erdmann ('85), and which might possibly be considered identical with the form under consideration.

The tentacles are completely infolded in the majority of the individuals of the colonies I have examined, being visible, however, in a few cases. They are short, as is usual in Zoanthids, and are arranged in two cycles, their number being in the neighborhood of fifty - fifty-six in one specimen in which they could be counted. Nothing worthy of note was observed in connection with the disk, but in connection with the stomatodæum it may be stated that its siphonoglyph was deep, about one-third of the total surface of the stomatodæum being occupied by its smooth walls.

The mesenteries are arranged in the microtype (brachycnemic, Haddon), and there are about twenty-eight to thirty-two pairs. Each has a single lacunar space near its point of attachment to the column wall, and its mesoglœe is thinner than is usual. Three of the individuals were sexually mature, and it is interesting to note that both ova and spermatozoa were present in the same individual, this species, like that observed by Erdmann ('85), being hermaphrodite.

\section{Isaurus Duchassaingi (Andres)}

Synonyms: Zoanthus tuberculalus Duch. \& Mich. I860.

Antinedia tuberculata Duch. \& Mich. 1864.

Antinedia Duchassaingi Andres. I883.

This species was originally described by Duchassaing, in a paper ('50) to which I have not access at present, as Zoanthus tuberculatus, the generic name being supplanted in a subsequent paper ('64) by Antinedia. In my paper on the Actiniaria of the Bermudas ('89a) I considered this latter genus to be identical with the genus Mammillifera as defined by Erdmann ('85); since then Haddon, in a paper writ- 
ten in conjunction with Miss Shackleton (' $9 \mathrm{I}$ ), has shown that there is little probability that the species assigned to the genus Mammillifera by Erdmann present the characters of the forms upon which that genus was founded by Lesueur ('I 7 ), and employs the generic term used by Gray ('28) for a tuberculate Zoanthid. I agree with Haddon's conclusions as to this matter, and have therefore followed his example in using the name Isaurus.

The form described by Gray was from an unknown locality and was given the specific name tuberculatus. I found among the Bermudan forms which I studied a species which seemed to agree closely with Gray's descriptions, and I identified it with his species. At the same time I also identified the species described by Duchassaing and Michelotti with this same form, an identification I now find to have been erroneous. The tuberculate Zoanthid in the Northrop collection is undoubtedly identical with the form described by Duchassaing and Michelotti, but it presents unmistakable differences from the Bermuda species, and must be regarded as distinct from it. The specific name given by Duchassaing and Michelotti being preoccupied by Gray's species, a new name must be bestowed, and the term proposed by Andres ('83) seems most appropriate. Duchassaing and Michelotti's species may therefore be known as Isaurus duchassaingi.

The appearance of the living animal in its contracted condition is shown in fig. 6, and I take the following description of it from Dr. Northrop's notes. The animals are found growing in groups of five or six, for the most part disconnected, though one specimen had connected with it a smaller individual, evidently produced by budding, and it may be presumed that each group owes its 'existence to this process, the various individuals separating from one another after a time. Duchassaing and Michelotti figure two individuals united by a stolon-like cœnenchyme, but in the preserved individuals I examined separation had taken place. In color the polyps were yellowish, closely resembling their surroundings, the disk and tentacles being of the same color as the column. The base is firmly adherent, and the column is "nearly cylindrical, but generally contracted near the base and often at intervals above, giving the animal a rather grotesque appearance. When slightly contracted the column bears a number of tubercles, which, though irregularly distributed, are more numerous near the top. In preserved and contracted specimens these tubercles are 
quite conspicuous." I can add to this statement as to the distribution of the tubercles the fact that the tubercles are more numerous and more perfectly developed upon one side of the column than on the other, the arrangement described by Haddon and Miss Shackleton ('9i) for I. asymmetricus being thus recalled.

The column wall is very much thinner than that of $I$. tuberculatus, and in addition does not show any of the large canals filled with cells, so abundant in the Bermudan form. Numerous canaliculi and scattered cells, the latter frequently placed in the canaliculi, occur, the mesogloa being otherwise structureless. The ectoderm of the column presents the arrangement which is usual in Zoanthids, being covered by a layer of mesoglœa, the subcuticula, from which trabeculæ extend inwards to unite with the general mesogloa, cavities being thus formed which inclose packets of ectoderm cells (fig. 7). Externally to the subcuticula is a delicate cuticula to which foreign particles adhere, and the ectoderm cells contain numerous Zoöxanthellæ. This arrangement is identical with what I have described for I. tuberculatus (' $89 a$ ), and agrees in its essential particulars with the accounts of the majority of the authors who have given the matter their attention. Quite recently Von Heider ('95), in his account of Zoanthus chierchia, has come to the conclusion that the trabeculæ which separate the various packets of ectoderm are cells, and that the subcuticula is formed by the fusion of their outer ends. Such an interpretation of the appearances is certainly not applicable to either of the species of Isaurus I have examined; the trabeculæ are so thick that their continuity with the mesogloa is beyond question, and, furthermore, the structure of the subcuticula shows it to be identical with the matrix of the mesoglœa. Nor do the appearances presented by such a form as Zoanthus sociatus warrant the belief that the trabeculæ are otherwise constituted than in Isaurus, and so far as my observations are concerned they tend to show that the conclusions of Von Heider are erroneous.

The tubercles are thickenings of the mesogloa, but each contains also a cavity lined with cells continuous with the endoderm. Dr. Northrop's notes contain the following description of the tubercles: "In places the mesoglœa contains on its inner side deep cavities which are lined by the endodermis. The muscular layer of the mesoglœa, however, does not enter the cavity, but forms a ring around its base (i.e. its mouth); so that when contraction takes place, the base of the 
cavity is drawn up like a purse and the body wall bulges out and forms a tubercle."

The upper portion of the column, which, in completely contracted individuals, forms the apex, is destitute of tubercles and is furnished with numerous longitudinal ridges. The sphincter muscle 'is strong and has the form represented in fig. 8, being simple, though showing a tendency to be divided into two parts, an evident constriction ( $c r$ ) occurring upon it. This is not an individual peculiarity, as I have found it in three individuals examined, and it is interesting as forming an intermediate condition between the simple sphincter of $I$. tuberculatus and the double one of the genus Zoanthus.

The tentacles are arranged in two rows, and their number seems to be double that of the pairs of mesenteries.

The mesenteries are arranged on the microtype, and vary in number in the different individuals from eighteen to twenty-three pairs. They are much more slender than those of $I$. tuberculatus, and though thickened towards their insertion with the column wall, yet this thickening is slight when compared with that of tuberculatus. Two or three slightly elongated (in section) canals are found in the thickened portion of the perfect mesenteries, the imperfect ones containing but one canal. No reproductive organs occurred in any of the specimens examined.

The stomatodæum presents a well-developed siphonoglyphe, and its surface is thrown into numerous marked ridges which correspond in a general way, but not accurately, with the intervals between successive pairs of perfect mesenteries.

\section{LIST OF REFERENCES}

I886. ELLIs, J. - The Natural History of Many Curious and Uncommon Zoophytes collected from Various Parts of the Globe, systematically arranged and described by Daniel Solander. London. I 786.

I8I7. LESUEUR, C. A. - Observations on Several Species of the Genus Actinia; illustrated by figures. - Journ. Acad. Nat. Sci. Philadelphia. Vol. I. I8I7.

I828. GrAy, J. E. - Spicilegia Zoölogica. London. ז828.

r85o. Ducenassarng, P. - Animaux radiaires des Antilles. Paris. 1850.

i86o. Duchassaing, P. ex Michelotit, G. - Memoire sur les Coralliaires des Antilles. - Mem. de l'Acad. Sci. Turin. Ser. II. Tome XIX. I860.

i864. Duchassaing, P. eт Michelotti, G. - Supplément an Memoire sur les Coralliaires des Antilles. Mem. de l'Acad. Sci. Turin.. Ser. II. Tome XXII. I864. 
1882. HeRtwig, R. - Report on the Actiniaria. Scient. Results of the Voyage of H. M. S. Challenger during the Years 1873-1876. Zoology. Vol. VI, Part XV. I882.

I883. Andres, A. - Le Attinie. Atti dei Lincei. Ser. 3. Vol. XIV. I883.

1885. ERDMANN, A. - Ueber einige neue Zoantheen. Ein Beitrag zur anatomischen und systematischen Kenntniss der Actinien. Jenaische Zeitschr. Naturwiss. Bd. XIX. I885.

r888. Hertwig, R. - Report on the Actiniaria. Supplement. Scient. Results of the Voyage of H.M.S. Challenger during Years 1873-1876. Zoölogy. Vol. XXVI, Part LXXXIII. I888.

I889. MCMURRICH, J. P. - The Actiniaria of the Bahama Islands, W.I. Journal of Morphology. Vol. III. r889.

I889a. MCMURRICH, J. P. - A Contribution to the Actinology of the Bermudas. Proc. of the Acad. Nat. Sci. Philadelphia. 1889.

I89o. Wrrson, H. V.- - On a new Actinia, Hoplophoria coralligens. Studies from the Biolog. Labor. Johns Hopkins Univ. Vol. IV. I89o.

I89r. Haddon, A. C., AND Shackleton, Alice M. - Reports on the Zoölogical Collections made in Torres Straits, by Professor A. C. Haddon, I888-I889. Actiniæ. I. Zoantheæ. Scient. Trans. Royal Dublin Soc. Ser. II. Vol. IV. I8gI.

I893. McMurrich, J. P. - Report on the Actiniæ collected by the U. S. Fish Commission Steamer Albatross, during the Winter of $1887-1888$. Proc. U. S. Nat. Museum. Vol. XVI. I893.

I895. VON HEIdER, A. - Zoanthus Chierchiæ, n. sp. Zeitschr. für wiss. Zoologie. Bd. LIX. I895.

\section{EXPLANATION OF PLATE XVII}

Fig. x. Transverse section through tentacle of Heteractis lucida. $\quad t b=$ tubercle. Zeiss C 2.

Fig. 2. Transverse section through a pair of mesenteries of the first cycle of Heteractis lucida. Zeiss A 2.

Fig. 3. Diplactis bermudensis, natural size. Drawn by Mrs. Northrop.

Fig. 4. Zoanthus nymphaus, $\times_{3}$. Drawn by Mrs. Northrop.

Fig. 5. Longitudinal section through the upper part of the column wall of Zoanthus nympheus, showing the sphincter. $s p^{\prime}=$ upper and $s p=$ lower part of the double sphincter. Zeiss a 2.

Fig. 6. Isaurus Duchassaingi, natural size. Drawn by Mrs. Northrop.

Fig. 7. Portion of a transverse section through the column wall of Isaurus $D u$ chassaingi. $c u=$ cuticula; $s c u=$ subcuticula; $e c=$ ectoderm; $m g=$ mesoglœea.

Fig. 8. Longitudinal section of the upper part of the column wall of Isaurus Duchassaingi, showing the sphincter. $c r=$ constriction almost dividing the sphincter. 


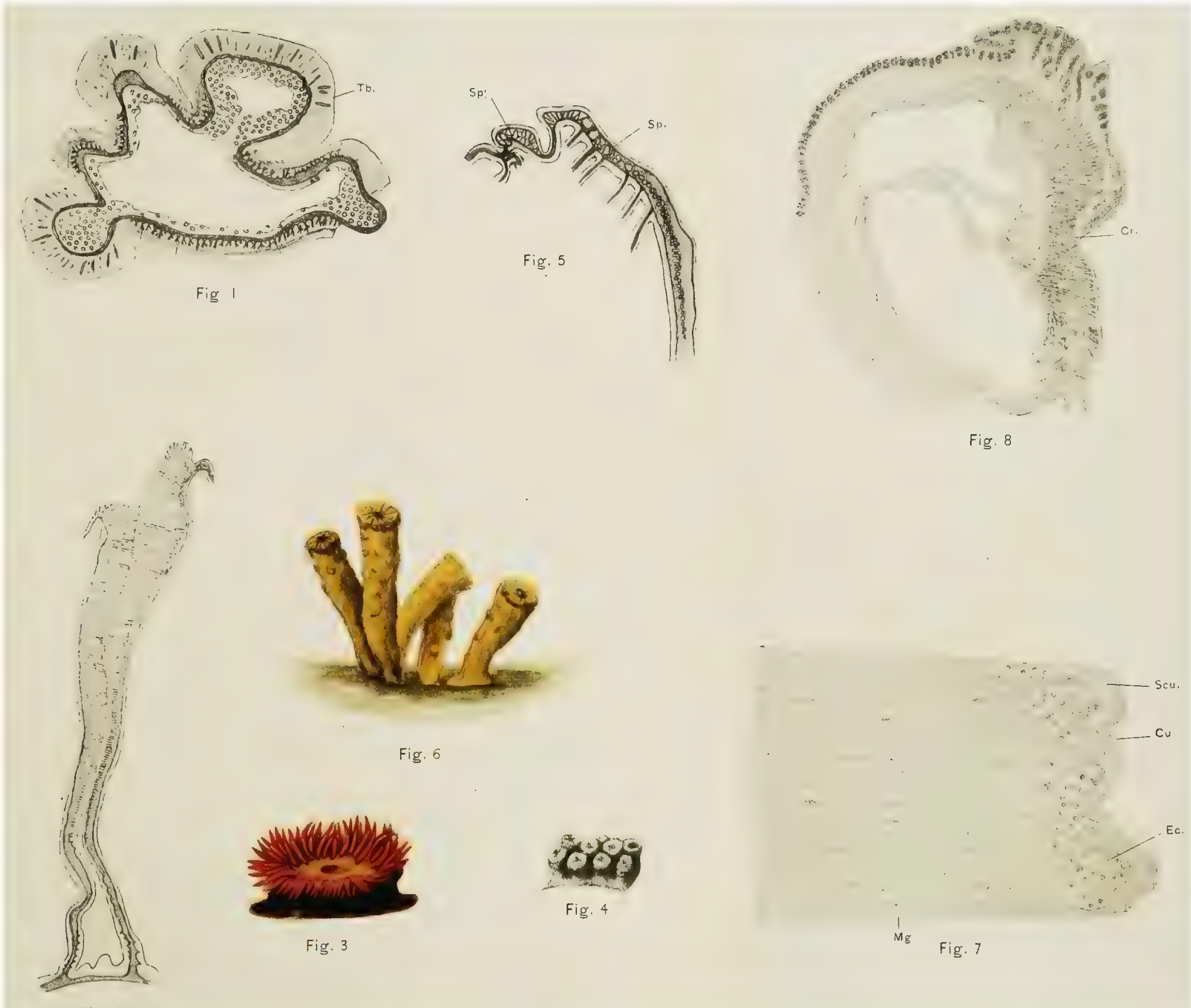

Fig. 2 



\section{APPENDIX}

SINCE the above notes were published in 1896 additional observations have shown the advisability of modification of the systematic position assigned to two of the forms described.

Heteractis lucida was retained in the genus to which Duchassaing and Michelotti had referred it thirty years earlier, on account of the peculiar structure of the tentacles. Duerden, ${ }^{1}$ however, in 1898 , called attention to the fact that the tubercles borne upon the tentacles were equivalent to the bands of nematocysts which occur upon the tentacles of another West Indian form, Aiptasia annulata Lesueur, and consequently assigned it to the same genus, repeating his conclusion that this was its proper position in a subsequent paper. ${ }^{2}$ In its other structural peculiarities, notably in its weak mesoglœal sphincter, lucida closely resembles other species of Aiptasia, and I now agree with Duerden that it ought to be assigned to that genus.

The other species which calls for mention is Diplactis bermudensis. My original description of this form was based upon specimens from the Bermudas, and in 1898 Verrill $^{3}$ described a form from the same locality which is apparently identical, so far as may be judged from the description of the external form and coloration which is all that Verrill's account includes. Verrill, however, assigns his form to the genus Actinia, naming it A. bermudensis, and this, I now believe, is the position to which my Diplactis bermudensis should also be assigned, its structural peculiarities being more in harmony with those of the genus Actinia than with those of the family Phyllactidæ to which I originally assigned it. I have already stated elsewhere my altered opinions on this matter and merely reaffirm them here. The correct name for the species is Actinia bermudensis (McMurrich) Verrill, and it should therefore be referred to the family Actinidæ instead of to the Phyllactidæ.

'Duerden, J. E., "The Actinaria around Jamaica," Journ. Inst. of Jamaica, II, r 898 , p. 457.

${ }^{2}$ Duerden, J. E., Report on the Actinians of Porto Rico, Bull. U. S. Fish Com. for r900, Vol. 2, p. 355. Washington, I902.

${ }^{3}$ Verrill, A. E., Descriptions of new American Actinians, with critical notes on other ${ }^{-}$species I. Am. Journ. Sci. (IV), VI, I898, p. 495.

1 McMurrich, J.P., "A Revision of the Duchassaing and Michelotti Actinian types in the Museum of Natural History, Turin," Boll. Mus. Zool. ed. Anat. Comp. R. Univ. di Torino, XX. I905. 


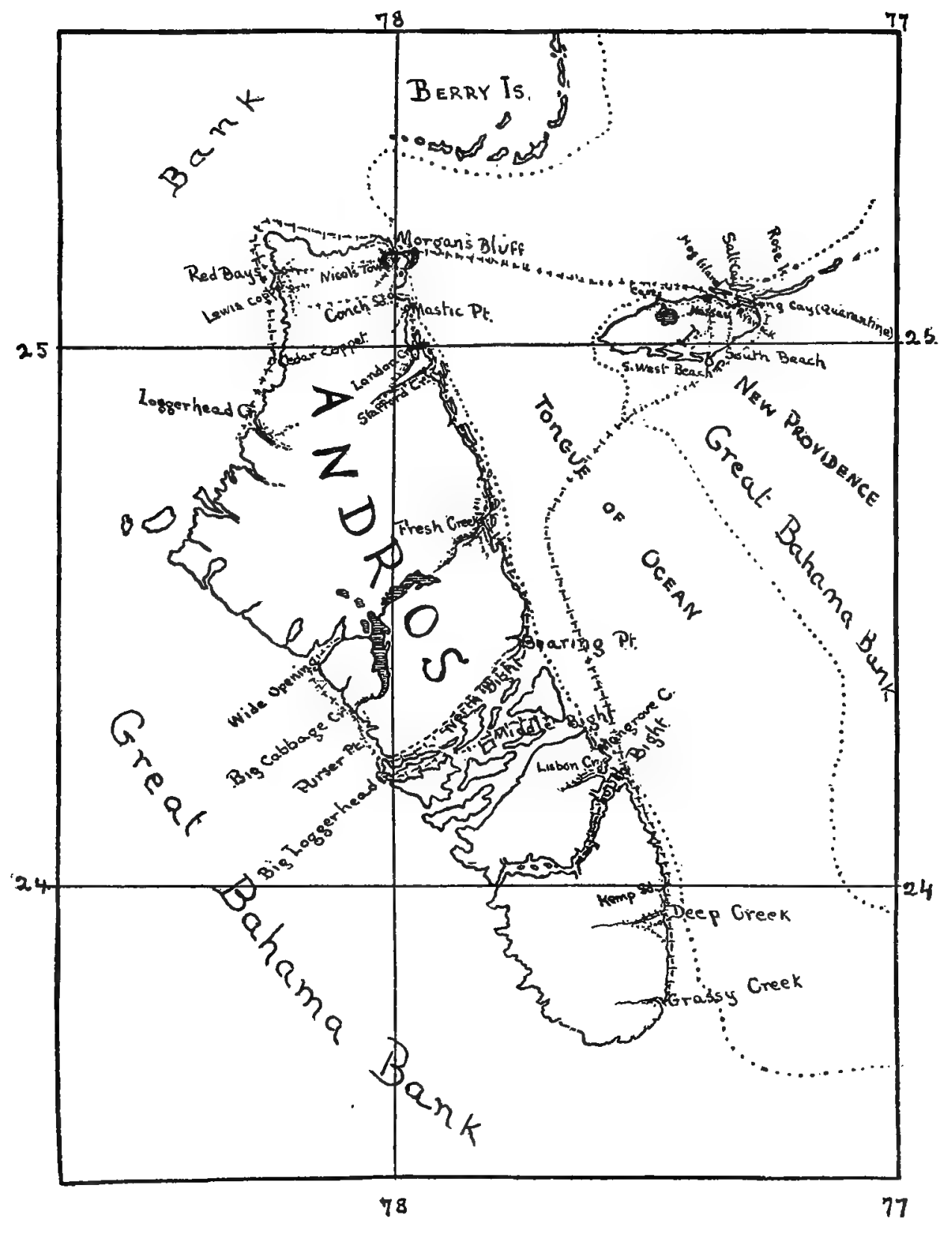




\title{
FLORA OF NEW PROVIDENCE AND ANDROS ${ }^{1}$
}

WITH AN ENUMERATION OF THE PLANTS COLLECTED BY JOHN I. NORTHROP AND ALICE R. NORTHROP IN I8go

\author{
By ALICE R. NORTHROP
}

\section{INTRODUCTION}

DURING the latter part of 1889 a report of the work in the Bahamas of the Danish botanist, Baron Eggers, was received at the herbarium of Columbia University, and with it a letter from Sir William ThiseltonDyer, expressing a hope that American botanists would continue the exploration. My husband, Dr. John I. Northrop, Instructor in Zoology at Columbia University, was at that time contemplating a Southern trip for the purpose of studying and collecting marine invertebrates. Sir William Thiselton-Dyer's letter was brought to his notice, and the result was that a Bahaman trip was planned with both objects in view. Over six months were spent on the islands, from January to July, I89o. Of this time two months were passed on the island of New Providence, where the time was mainly taken up with zoölogical work, and the remainder on Andros, where the most interesting plant collections were made.

In order to understand properly the distribution of the plants and the relations of the flora, it will be necessary to give a general idea of the position and conformation of the two islands visited. New Providence is one of the smaller islands of the group, being only about twenty miles long and seven wide. It lies on the northern edge of a portion of the Great Bahama Bank. Nassau, the seat of government and a well-known health resort, is situated on the slope of a ridge that runs along the northern shore of the island. The highest point of this ridge, Fort Fincastle, is about one hundred feet above sea-level. From here one has an excellent view of the city and harbor, the latter protected by the narrow outlying cays known as Hog Island, Long Island,

${ }^{1}$ Memoirs Torrey Botanical Club, Vol. XII, No. I, I902. 
or Quarantine, and, farther seaward, Salt Cay. In the opposite direction a low level country, covered with trees and dotted here and there with cocoanut groves, stretches away to the Blue Hills.

Roughly speaking, the physical features of New Providence may be described as a rocky ridge, about one hundred feet above sea-level at its highest part, extending along the north side and covered with a growth of angiospermous trees and shrubs; a low central plain out of which rises a second ridge, the Blue Hills, like the first, but narrower and lower; then a slightly undulating region covered with the Bahama pine, extending to the low and swampy south shore. The depressions of the central plain are occupied by two quite large bodies of brackish water, Lake Cunningham and Lake Killarney. The latter is the larger and contains numerous mangrove islets.

The rock of both islands is of Eolian formation; it is very hard at the surface, but becomes so much softer below that it is sawn into blocks for a building stone. The surface erosion is most striking and characteristic. In many places the rocks are fairly honeycombed with holes, pits, and cavities of all sizes; often sharp jagged points project, making walking extremely difficult. The largest of the pits are locally known as "banana holes" because they usually contain considerable earth in which the people plant their bananas. They vary greatly in size and shape, the majority being probably from eight to ten feet in diameter; they are occasionally twenty feet in depth, but are usually much shallower. Their sides are often lined with delicate ferns, many of which grow nowhere else.

There is little or no soil. Mark Catesby, the first naturalist to visit the islands, wrote in I754: "The Bahama Islands may not only be said to be rocky, but are in reality entire Rocks, having the surface in some Places thinly covered with a light Mould which in a series of Time has been reduced to that Consistence from rotten Trees and other Vegetables. Thus much of the Character of these Islands being considered, one would expect that they afforded the disagreeable Prospect of bear Rocks: But on the Contrary they are always covered with perpetual Verdure and the Trees and Shrubs grow as close and are as thick cloathed with Leaves as in the most luxuriant Soil." In some places the soil is reddish, and this is considered the most fertile.

Six weeks of our stay were spent at Ryswick, a country place that we rented on the shore about three miles east of Nassau. Although 
the greater part of this time was given to the zoölogical work, still between times we collected over two hundred species of plants, crossing the island several times and exploring it in many directions. The collection, of course, included many cosmopolitan weeds and introduced plants that were found in Nassau and its environs. Among the latter, growing commonly about the city, were the glossy-leaved almond tree (Terminalia Catappa), the graceful Spanish cedar (Casuarina equisetifolia), the buttressed ceiba or silk-cotton tree, the sand-box tree (Hura crepitans), and the beautiful flamboyant (Poinciana regia) with its fern-like foliage.

Having completed the zoölogical work that had been planned, we made a diligent study of the chart, and finally decided to visit Andros next as the largest and least known of the islands, and the one from which no botanical collections had ever been made. Although the nearest part of Andros is only twenty-five miles from New Providence, we could get but little information concerning it until we met Mr. Alexander Keith, of Edinburgh, who had a sisal plantation on Andros. To him we were indebted for many favors both at this time and later. A "norther" delayed our sailing for ten days, but we finally reached Andros March I4, and remained there until July 3.

Andros is by far the largest island of the group, being nearly one hundred miles long and forty or fifty wide in its broadest part and having an area of over nineteen hundred square miles. It is in reality not one island but a group of islands, the larger northern portion being separated from the southern and central parts by shallow channels known as "bights." There is a northern, a middle, and a southern bight, but they are so filled with cays that the whole archipelago, as it might be termed, is called by the general name of Andros. In its prominent physical features Andros resembles New Providence, although its greatest length runs north and south instead of east and west, as in the case of New Providence. It has a rocky ridge extending along the east coast, except at the extreme southern end, extensive pine barrens in the interior and low mangrove flats on the opposite side. On Andros, however, the last cover a much greater portion of the island and constitute its most characteristic feature. The local name of this region is "swash," 1 a most appropriate term, as in wet seasons it is half under water. The pine belt is always spoken

\footnotetext{
${ }^{1}$ See illustration - page 218.
} 
of as the "pine-yard," 1 and the hardwood growth on the rocky, elevated portion is called the "coppet."

The pines are most abundant on the northern part of the island, and at the extreme southern end, below Grassy Creek, where the rocky ridge is wanting, there were said to be no pines. None could be seen from the shore, but we did not cross the island so far south. At Nicol's: Town, the most northerly settlement, the belt of coppet is only about three quarters of a mile wide; the pine-yard then begins and extends to the swash on the other side. At Conch Sound, a few miles south of Nicol's Town, the pines come down to the eastern shore, but below Mastic Point, the next settlement, the belt of coppet becomes much wider. The swash is more extensive than the other two regions put together and covers hundreds of square miles; next in extent are the pine barrens, while the coppet is scarcely more than a comparatively narrow belt or fringe along the east coast. The pines sometimes extend in long points far out into the swash.

Numerous creeks drain the island, the majority being on the east side; in very wet seasons there is said to be water communication between those of the east and west side. The creeks are generally narrow and winding, but they occasionally spread out into lakelike expansions in the interior. The largest of these lakes are on the west side, near Wide Opening. A number of the creeks are fresh at their source.

All the settlements are on the east side, with the exception of a small one at Red Bays on the northwestern end of the island. Nicol's Town is one of the largest, and when we were there had about three hundred inhabitants. At the time we visited Andros there were but seven white people on the entire island. There were no roads, and communication between the settlements was entirely by water, the reef making a safe channel for small boats all along the eastern coast. The west coast is exceedingly shallow, so much so that our boat, drawing only about two feet of water, had sometimes to anchor a quarter of a mile from the shore. Even at the edge of the Great Bahama Bank, sixty or seventy miles farther west, there are but three or four fathoms of water. The only visitors to this coast are the "spongers."

During the four months spent on Andros we explored it quite thoroughly, crossing it several times and almost circumnavigating it, making stops at the various settlements on the way or camping out on

\footnotetext{
${ }^{1}$ See illustration - page 2 Ig.
} 


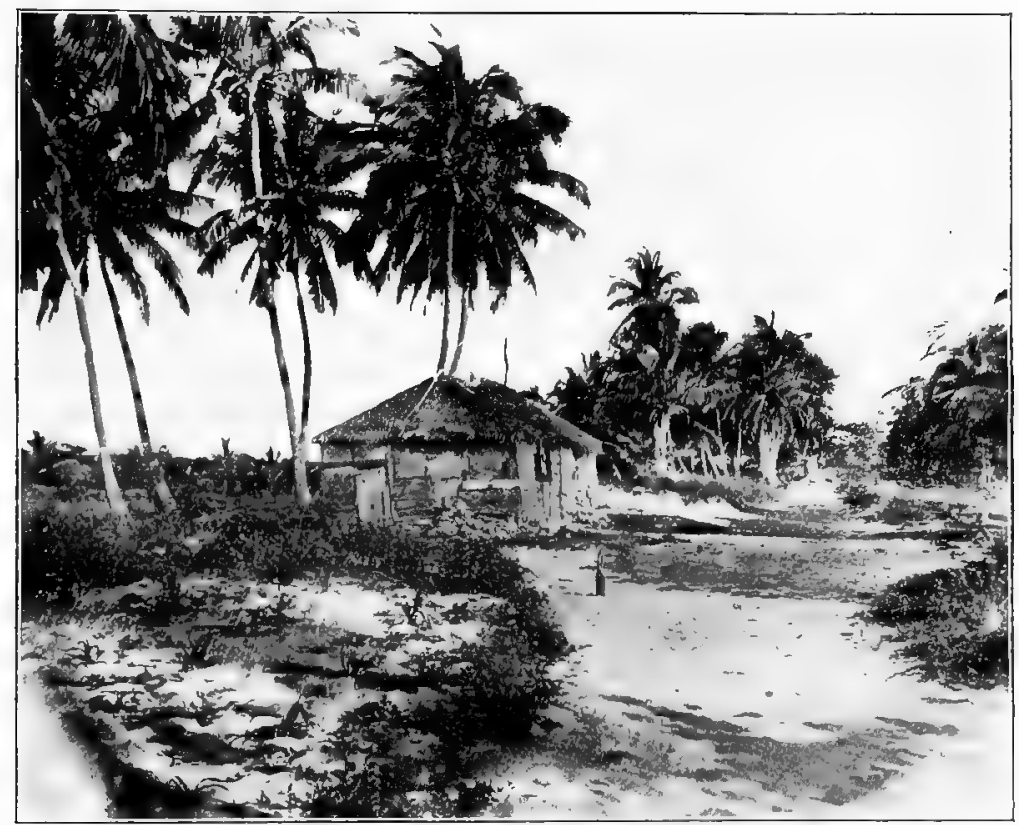

Main Street in Nicol's Town. 

the west side where there were no settlements. From one to six weeks were spent at each of the following places: Nicol's Town, Conch Sound, Mastic Point, Fresh Creek, Lisbon Creek, and Deep Creek on the east side, and Red Bays on the west. We sailed through the northern and middle bights and partly through the southern, and penetrated the following creeks, most of them to the head of navigation for a rowboat; London, Stafford, Fresh, Lisbon, Deep, and Grassy creeks on the east; Loggerhead and Big Cabbage creeks and Wide Opening on the west.

\section{BOTANICAL REgIONS}

The following botanical regions, each with markedly characteristic plants, were well defined on both islands : First, the maritime or coast flora of the northern side of New Providence. and the east side of Andros. These shores were rocky with scattered sandy beaches. The following plants were common on both islands: the sea-grape (Coccolobis uvifera), the buttonwood (Conocarpus erecta), the sandfly bush (Rhacciallis rupestris), and Strumfia maritima. The wild sapodilla (Mimusops dissecta), Joe-bush (Jacquinia Keyensis), Cordia Sebestena, Borrichia arborescens, and the ram's horn (Pithecolobium Unguis-cati) were always found near the shore, while on the sandy beaches flourished the cocoa-plum (Chrysobalanus Icaco), Scavola Plumieri, Suriana maritima, Tournefortia gnaphaliodes, the bay lavender (Ambrosia hispida), Euphorbia buxifolia, the widely distributed Salicornia ambigua, Sesuvium Portulacastrum, Cakile aqualis, and the horse-bean (Canavalia obtusifolia).

Second, the "coppet," or growth of angiospermous trees and shrubs found on the more elevated parts of the islands and on the rocky ridges. The highest elevation on either island was about one hundred feet, but the ridge was in most places considerably lower than this. On Andros the highest point was near the center of the island, at the mouth of the northern bight, marked as Salvador Point on the charts, but locally known as Bearing Point. The surface erosion was much more marked on Andros than on New Providence. In some places the rock was honeycombed with pits of all sizes, in others it was covered with sharp knife-like projections. Banana holes were far more numerous. On both islands the elevated ridges, covered with the "coppet," showed the greatest amount of erosion. The trees 
most commonly met with were the gum elemi (Bursera Simaruba), the poison wood (Metopium), the wild cassada (Dipholis salicifolia), the horseflesh (Lysiloma paucifoliola), and the Madeira (Swietenia Mahogani). As a rule the trees were comparatively small, not more than a few inches in diameter. The largest and tallest were seen in what was called the "high coppet" near Deep Creek, Andros. One horseflesh there measured five and a half feet in circumference at a distance of four feet from the ground, another six feet four inches, while the largest mahogany seen was between two and three feet in diameter. Common among the underbrush were the cockspur thorn (Pisonia aculeata), the chawstick (Gouania Domingensis), hardhead (Phyllanthus epiphyllanthus), Erithalis fruticosä, and Duranta repens. Among the climbing plants the dream vine (Echites umbellata), Triopteris rigida, and Ipomcea sinuata were common. The coppet was usually quite difficult to penetrate, the trees being mostly small and close together and the underbrush dense.

The third region was the "pine-yard" or pine barrens. This was a comparatively level region occupying the interior of both islands and covered almost exclusively with the Bahaman pine (Pinus Bahamensis). Where the ground was a little elevated there were small coppets or islands, as it were, of angiospermous trees; where it was lower and more moist, occasional clumps of palmetto varied the monotony. The Bahaman pines are tall and slender and do not branch until quite near the top. The tallest we saw was about seventy or eighty feet in height, and the largest was four feet and nine inches in circumference. They do not grow close together, but are usually from ten to twenty feet apart even when small. A tall brake known as the "May-pole" (Pteridium caudatum) was very characteristic of the pine belt. It often formed almost impenetrable thickets six or seven feet in height, while at one place on Andros we found it growing nine feet in height. The cinecord (Acacia choriophylla) was common in the pines, as were also, among the lower plants, Ascyrum hypericoides, Tetrazygia bicolor, Linum Bahamense, Ernodea littoralis, and Vernonia Bahamensis. The showy sedge (Dichromena colorata) and the purple orchid (Bletia verecunda) were abundant in the pines and were also occasionally found on the savannas. In many parts of the pine barrens on Andros there was no underbrush, nothing but a coarse grass called "bed-grass" (a species of Andropogon), relieved here and there by 


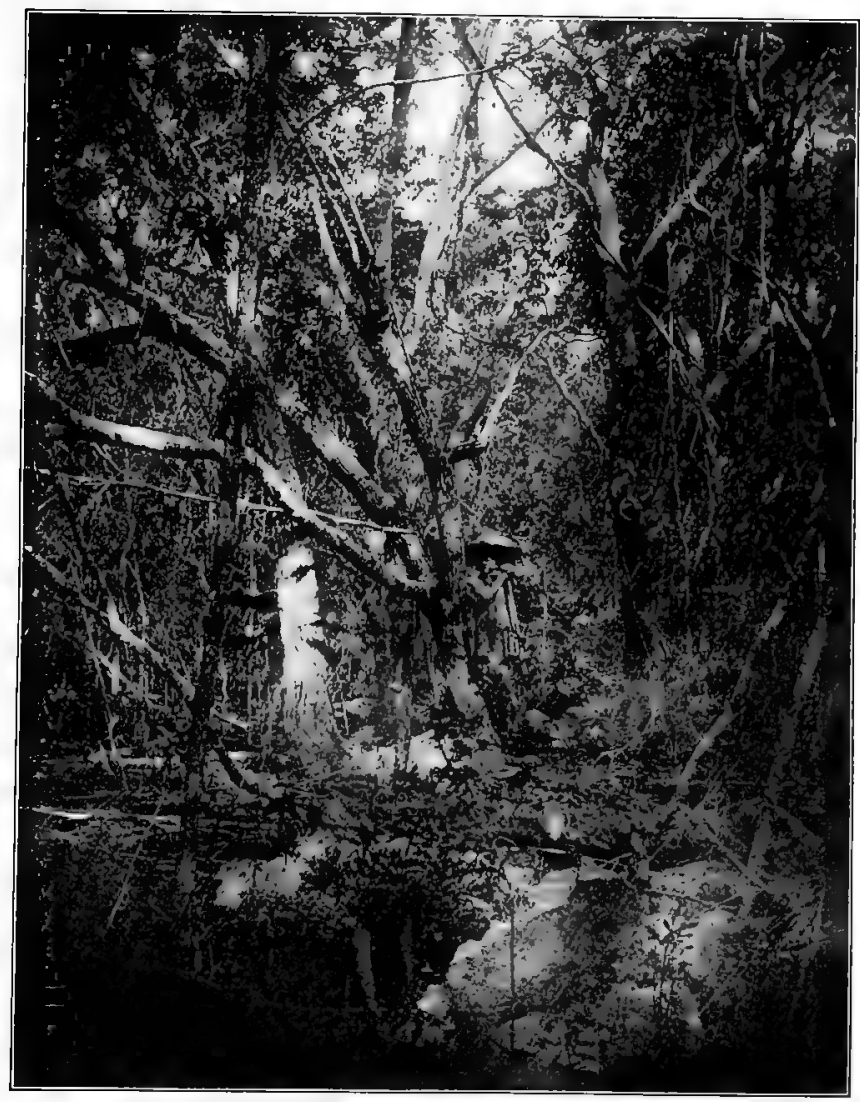

In the "High Coppet" near Deep Creek. 

the crimson flowers of Ipomae repanda. As one approached the western edge of the pines, the ground became less rocky, the trees smaller and smaller, and the palmettoes more numerous until one finally emerged on either swash or savannas.

The savannas, constituting a fourth distinct botanical region, were found only on Andros. They were level prairie-like stretches, lying, as a rule, between the pines and the swash. They were most common in the northwestern part of the island. The ground was not rocky and was covered, for the most part, with a coarse sedge called "saw-grass" (Cladium Jamaicense); there were also occasional clumps of palmetto or brier tree (Terminalia spinosa). This region proved excellent botanizing ground, and by far the greater number of the plants found there were met with nowhere else. Flaveria linearis, Polygala Boykinii, Eustoma exaltatum, Aletris bracteata, Gyrostachys tortilis, and Gerardia purpurea were common and in some places Limodorum tuberosum, Buchnera elongata, and Samolus ebracteatus.

The fifth plant region was the "swash." On Andros this region, as has been said, was very extensive and comprised hundreds of square miles. Here the eroded coral rock, such a prominent feature of the coppet and the pine barrens, was replaced by soft, calcareous mud, in some places more or less hardened, in others very soft. There were numerous ponds and lakes in this region which we were told became connected in wet seasons, making a network of waterways navigable by small boats for many miles. We were there in a comparatively dry season, and the ponds were very shallow, having about three inches of water and eighteen inches of marl.

The scenery was monotonous and desolate. In many places, as far as the eye could reach, the ground seemed perfectly flat and covered with small mangroves, the salt-bush (Avicennia nitida), and a low form of buttonwood (Conocarpus erecta), none more than a few feet in height. The plants were in reality quite scattered and a considerable distance apart, but seen at a distance, the effect was that of a smooth expanse of lawn. Here and there a dark line of pines showed on the horizon or one caught the gleam of water, but as a rule only clumps of palmettoes or a few shrubs varied the monotony. In some places, especially near the creeks, palmettoes were abundant, the most common being the silver thatch (Thrinax Bahamensis), the hog cabbage (Cyclospathe Northropi), and the saw-tooth cabbage 
(Paurotis Androsana) were occasionally seen; all were of small size. Toward the southern end of the island the mangroves sometimes attained considerable size and formed the most prominent feature of the landscape. This desolate, uninhabited region is a paradise for water birds, which were found here in great numbers. The flamingoes were the most interesting, and these we often saw while on the west side of the island.

I have described the botanical regions in such detail because since we collected in the Bahamas many of the localities we visited have been destroyed, botanically speaking, by being cleared for the cultivation of sisal. The work was just beginning when we were there, a few sisal plantations having been started on both New Providence and Andros. Several years later thousands of acres had been cleared and planted with sisal. For this purpose both coppet and pine barrens were available, but not the swash. Large companies were formed, a great amount of money was spent in clearing and planting, in making roads, and I believe even a small railroad was built on Andros. It was confidently expected that large fortunes would be made, but after three or four years' trial these hopes proved to be visionary, and I have since heard that many of the plantations have been given up and the land allowed to lapse into its former wild state. It is highly probable, however, that the flora of Andros has suffered more or less change through the extensive clearing and the probable introduction of cosmopolitan weeds.

\section{Previous Collectors}

Mark Catesby explored and collected along the southern Atlantic coast from I73I to I743 and during that time made a trip to the Bahamas, visiting New Providence and also touching incidentally at Andros. Some of the plants he collected were figured in his "Natural History of Carolina," published in I754. The next record we have of Bahaman plants were the collections sent to Sir William Hooker by Mr. Swainson between 1838 and 1842 . These were described by Grisebach and incorporated in his "Flora of the British West Indies," published in I864. Less than two hundred species were there recorded from the Bahamas. Between I880 and I887 Mr. L. J. K. Brace, of Nassau, sent to Kew through Governor Robinson a large number of Bahaman plants. A list of these has been incorporated in a Provisional List of the Plants 
of the Bahama Islands, by Gardiner, Brace, and Dolley, which was published by Dr. Dolley in the Proceedings of the Academy of Natural Sciences of Philadelphia in I88g. This list, however, is not always clear as to which are native and which cultivated species, and in the majority of cases the place of collection is not given. A small collection of plants made by a Mr. Cooper were presumably sent to Dr. Torrey at Columbia University, as they form a part of the Torrey herbarium. With very few exceptions all the above collections were made on the island of New Providence.

In 1887 a grant was made by the British Association, for the investigation of the Bahaman flora, and the Danish botanist, Baron Eggers, undertook the work. He spent from November, I887, to April, I888, in the islands and brought back 3I4 species. A few were collected on Fortune Island and Long Island, but the great majority were from New Providence. Professor T. H. Herrick, of Johns Hopkins, visited Abaco in I886 and collected a small number of plants noted in the Johns Hopkins Univ. Circ. 6, 46. During the winter of I890-I89I Professor Albert S. Hitchcock, of the Missouri Botanical Garden, accompanied a party of naturalists, headed by Dr. J. T. Rothrock, of the University of Pennsylvania, on an exploring trip through the Bahamas. Eleuthera, Cat Island, Watling's Island, Crooked and Fortune islands, and Inagua were visited, as were also the islands of Jamaica and Grand Cayman. The report of the plants collected was published in 1893 by Professor Hitchcock in the Report of the Missouri Botanical Garden. The total number of plants there noted from the Bahamas was 380 , and of these two were described as new.

\section{Analysis of the Collection}

The collection enumerated in the following pages consists of $54^{2}$ species (46I exclusive of the cryptogams) to which are to be added six varieties and twenty-one cultivated plants. Two of the collection proved indeterminable on account of insufficient material, while fifteen could only be determined generically for the same reason. The total number of families of flowering plants represented is 93, the number of genera 304. The families most largely represented are Leguminosæ, with 45 species; Compositæ, with 34; Rubiaceæ, with 24, and Euphorbiaceæ, with $2 \mathrm{I}$; while Orchidaceæ, Convolvulaceæ, and Verbenaceæ 


\section{FLORA OF NEW PROVIDENCE AND ANDROS}

come next. The genus most largely represented is Ipomæa, of which we collected I3 species; eight species of Cassia were found, and six species each of Euphorbia, Coccolobis, and Tillandsia, while Passiflora and Eupatorium each have five species. As will be noticed, there is a very large proportion of genera to the number of species, in the majority of cases a genus being represented by but a single species.

Of the plants collected a new Chara was described and published by Dr. T. F. Allen, an Anastraphia by Mr. J. M. Greenman, of Cambridge, a Jacquinia by Professor $\mathrm{Mez}$, and new species of Casalpinia, Phyllanthus, Reynosia, and Casearia by Professor I. Urban, of Berlin in "Symbolæ Antillanæ." In addition new species of Hymenocallis, Aletris, Vanilla, Phoradendron, Pithecolobium, Cassia, Linum, Erythroxylon, Crossopetalum, Rhamnidium, Helicteres, Xylosma, Terminalia, Heliotropium, Tecoma, Catesbaa, Myrstiphyllum, Anguria, Metastelma, and Eupatorium are described in this paper, as well as two new genera of palms, Paurotis and Cyclospathe. The type specimens are in the herbarium of Columbia University. Sets are also at Kew, the Royal Botanical Garden at Berlin, the Gray Herbarium, the Field Museum of Natural History, and Geneva. As far as I can discover, the following genera have never before been reported from the Bahamas: Coccothrinax, Inodes, Aletris, Vanilla, Broughtonia, Polystachya, Cranichis, Limodorum, Hypoxis, Pedilanthus, Maba, Mitreola, Voyria, Trianosperma, and Aster.

My sincere thanks are due those who have assisted me in the preparation of this report, especially to the following specialists who kindly determined the cryptogams: Mr. Frank S. Collins, of Malden, Mass., the algæ; Dr. Albert Schneider the lichens; Professor Lucien M. Underwood the fungi; Mrs. Elizabeth G. Britton the mosses; and Professor D. C. Eaton who determined a number of the doubtful ferns in I89o. The report on the palms has been prepared by Mr. O. F. Cook, of the Department of Agriculture at Washington, to whom I here wish to express my obligations. Dr. Nathaniel L. Britton and Mr. George V. Nash kindly named the grasses, and Dr. Britton the sedges. I am also greatly indebted to Dr. Britton for advice on many points and for his kindness in comparing and identifying a number of our plants at Kew in I89r, also to him and to Dr. John K. Small for revising the nomenclature in many instances, and to Professor Underwood for revising the names of the ferns and other kindly assistance. A 


\section{FLORA OF NEW PROVIDENCE AND ANDROS 129}

number of doubtful specimens were compared by me at Cambridge in I897, and I take this opportunity of thanking Dr. Benjamin L. Robinson and his assistants for the kindness then shown me and for a number of determinations they were good enough to make for me the following year. I also wish to acknowledge gratefully several determinations made for me by the authorities at Kew in 1897 .

The new species have been most successfully drawn by Miss Mary V. Thayer, of Holbrook, Mass., to whom I wish to express my thanks for her careful work. ${ }^{1}$

\section{LIST OF PLANTS}

\section{THALLOPHYTA}

\section{MARINE ALGAE}

Determined by Mr. Frank S. Collins, of Malden, Mass., i8gr.

\section{CHLOROPHYCE $Æ$}

\section{Cladophorace}

ChжтомовPHA sp.? Lake Waterloo, near Nassau, Jan. (209). Cladophora sp.? Ft. Montagu, Nassau, Jan. (I63).

\section{Caulerpace}

Caulerpa clavifera Ag. Quarantine Cay, Nassau, Jan. (I82). Caulerpia ericifolia Ag. Lake Waterloo, Nassau, Feb. (30I). *Caulerpa plumaris Ag. Lake Waterloo, Nassau, Jan. (208).

\section{Codiace}

Peniculuds capitatus Lamour. Quarantine, Nassau, Jan. (I87). $\nmid$ Rhipocephalus PHenIX J. Ag. Quarantine Cay, Nassau, Jan. (Igo).

†Udotea Conglutinata Lamour. Salt Cay, Nassau, Jan. (233).

1 The long period that has elapsed since the collection of these plants and the publication of this report may call for a word of explanation. My husband was working up the zoölogical collections and I the plants when his sudden death occurred in June, I8gr. Since then ill-health has year after year prevented any continuous work, and the frequent lapses of time have made much revision necessary. My husband greatly assisted me in the beginning of the work, and my sole motive in continuing it was because of his interest in my doing it. 


\section{FLORA OF NEW PROVIDENCE AND ANDROS}

Udotea flabellata Lamour. Quarantine Cay, Nassau ( 183 , 300 ).

†HALImeda tridens Lamour. Salt Cay, Nassau. Quarantine Cay, Nassau, Jan. (I9I).

*Halimeda tuna Lamour. Salt Cay, Nassau, Jan. (232).

\section{VALONIACEE}

*Valonia egGrophila Ag.? Lake Waterloo, Nassau, Jan. (2io).

†Dictyospheria favulosa Decne. Quarantine Cay, Nassau (I88).

Microdictyon Agardhianum Decne. Salt Cay, Nassau, Feb. (273).

\section{DASYcLADACE}

†Dasycladus occidentalis Harv. Ft. Montague, Nassau, Jan. (I6I).

†Acetabularia CRenulata Lamour. Lake Waterloo, Nassau, Jan. (2II).

Cymopolia barbata Lamour. Silver Cay, Nassau, Jan. (I56).

Cymopolta Mexicana J. Ag. Silver Cay, Nassau, Jan. (I55). Blodgettia CONFERvoIdes Harv. Doubtful position and value. Quarantine (I92).

\section{PHÆOPHYCEÆ}

\section{FUCACE $x$}

Cystoseira myrica Kütz. Nicol's Town, Andros, March (337). *Turbinaria vulgaris Ag. Quarantine Cay, Nassau, Jan. (I85). Sargassum filipendula laxa J. Ag. Ft. Montague, Jan. (I 58 ). Sargassum sp. Salt Cay, Nassau, Feb. (268-275).

\section{Dictyotace}

- Dictyota dichotoma Lamour. Quarantine, Jan. (I77).

*Dictyota fasciola Lamour. Salt Cay, Feb. (274).

*Padina pavonia Gaillon. Silver Cay, Nassau, Feb. (I54).

Zonaria lobata Ag. Salt Cay, N.P., Jan. (259); Goat Cay, Andros, June (632). 


\section{RHODOPHYCE $Æ$}

\section{HELMINTHOCLADIACE E}

Lragora Cheyneana Harv. Salt Cay, Nassau, Feb. (272). Liagora elongata Zan. Silver Cay, Nassau, Jan. ( I53). †Liagora valida Harv. Goat Cay, Andros, June (748).

\section{Chemangiace $x$}

*Galaxaura lapidescens Lamour. Salt Cay, Nassau, Feb. $(260,27 \mathrm{I})$.

\section{RHODOMELACE $E$}

Laurencia Paniculata J. Ag. Quarantine, Nassau, Jan. (I79). Some specimens near L. obtusa Lamour.

*Digenia Simplex Ag. Quarantine Cay, Nassau, Jan. (I80). I8I).

†Polysiphonia Havanensis Mont. Ft. Montagu, Jan. (i6o,

†Pouysiphonia Pecten-Veneris Harv. Ft. Montagu, Nassau, Jan. (I59).

Polysiphonia sp.? Goat Cay, Andros, June (749).

†Dasya Gibbesir Harv. Ft. Montagu, Nassau, Jan. (I62).

\section{Ceramiaces}

*Centroceras clavulatum Mont. Quarantine Cay, Nassau, Feb. (302).

\section{CORALLINACE}

Lithothamnion? Quarantine Cay, Nassau, Feb. (304, 305). * Jania RUbens Lamour. Quarantine Cay, Nassau, Jan. (I78).

Notes on Distribution. - The species of marine algæ marked * are generally distributed in warm waters. The species marked $\dagger$ are limited to the West Indian and Florida region. "Liagora elongata and Cystoseira myrica are characteristic Red Sea plants; Liagora Cheyneana is an Australian species. Liagora elongata and Cymopolia Mexicana are, I think, new to the West Indian region, although it is now considered rather doubtful whether the last-named species is distinct from C..barbata." (F. S. Collins.) 


\section{CHARACE $\mathbb{E}$}

Chara depauperata T. F. Allen. New species. Bull. Torrey Club, 21, 267. I894. Fresh Water Pond, Hog Island, N.P., Feb. (258).

Chara sp.? In brackish water. Stafford Creek, Andros, May (547).

\section{LICHENES 1}

Cladonta gracilis (L.) Nyl.? (Not mature.) Nicol's Town, Andros (346).

Cladonta Flerkeana Fr. Nicol's Town, Andros (347).

Cladonia sp.? On palmetto. Red Bays, Andros, April (484).

Leptogium PUlchellum (Ach.) Nyl. Nicol's Town (444).

Leptogium tremelomes (L.) Fr. Nicol's Town (382).

Ramalina pusilla (Prev.) Tuck. Nassau (755).

With the exception of 484 , all are quite common and widely distributed species.

\section{FUNGI ${ }^{2}$}

Schizophylium alnedm (L.) Schröt. Nicol's Town, March (35I).

Clathrella crispa (Turpin) E. Fischer. Andros (798).

Diplocystis WRIGHTII B. \& C. Andros (777). Also reported from Inagua by Hitchcock.

Trametes cinnabarina (Jacq.) Fr. Andros (793).

Auricularia auricula (L.) Schröt. Andros (794).

Fomes igniarius (L.) Fr. Andros (797).

\section{BRYOPHYTA $^{3}$}

Tortula agraria (Sw.) Hedw. Nassau and Nicol's Town (34, $34 \mathrm{I}, \mathrm{I} 68)$.

HYophila Barbula (Schwaegr.) Hampe. Nassau (I69, I70).

Macromitrium insularum Mitt. Nicol's Town, Andros, March $(342,345)$.

Sematophylium Sericifolium Mitt. Nicol's Town (343, 530).

SyrRHopodon flavescens Mueller. Nicol's Town, March (344).

Octoblephardm albidum Hedw. New Providence, Nicol's Town, Feb. $(348,746)$.

1 Determined by Dr. Albert Schneider at Columbia University.

2 Determined by Professor Lucien M. Underwood.

${ }^{3}$ Determined by Mrs. Elizabeth G. Britton at Kew. 


\section{PTERIDOPHYTA}

SCHIZÆACE

ORNITHOPTERIS ADIANTIFOLIA (L.) Bernh. Common and variable; abundant in the pines. Nassau, Jan.; Nicol's Town, March (I2, I5, 83,300 ).

* Ornithopteris cicutaria (Kunze) Underw. (Anemia cicutaria Kunze, Linnæa, 9, 22. 1835.) On rocks, not common. Nassau, Jan. (165).

\section{POLYPODIACE}

*Dryopteris patens (Sw.) Kuntze. In banana-holes and rocks along roadsides; common and variable. Nassau, Jan.; Nicol's Town and Red Bays, April (I 73, 240, 44I, 469).

*Dryopteris asplenromes (Baker) Kuntze. Clefts of rocks, uncommon. Indusium small, pinnæ narrow and distant. Conch Sound, March (4I6).

Tectaria trifoliata (L.) Cav. On sides of banana-holes; not common. Conch Sound, May (562).

Davalita clavata Sw. Common. Nassau, Jan. (I33). Same as Wright $96 \mathrm{r}$.

*Asplenium dentatum L. Pinnæx large and close together. Caves near Nassau, Feb. (286).

Blechnum SerRulatum Rich. Caves near Nassau, Feb. (285). Same as Fendler I33.

Adiantum tenerum Sw. In banana-holes. Near Nassau, Feb.; Red Bays, April $(288,489)$.

Pteridium caudatum (L.) Maxon. "May-pole." Very common on both New Providence and Andros; makes dense thickets in the pine-yard six to eight feet high ( 3 ×3).

Pteris longifolia L. Common on walls. Nassau, Jan. (I8, 94).

VitTARIa lineata (L.) Sm. On palmettoes, not common. Red Bays, April (472).

Cheilogramma Lanceolatum (L.) Bloume. Leaves Io-I4 inches in length. On trees, not common. Nicol's Town, March (356).

ACROSTICHUM AUREUM L. "Wild ginger." In low ground, not common. Conch Sound, May; Deep Creek, June (408, 7I 4). 7I4 was growing in a banana-hole; the leaves were shorter than in 408 , fertile almost to the base, and the rachis was deeply sulcate. 


\section{FLORA OF NEW PROVIDENCE AND ANDROS}

Phlebodium aureum (L.) R.Br. Common on palmettoes. Hog Island, N.P., Feb.; Purser Point, Andros, June (249, 625, 665, 720). No. 665 is a sport with leaves very glaucous and pinnæ deeply crenate.

Polypodium PolypodioIdes (L.) A. S. Hitche. On trees, not uncommon. Nicol's Town, April; Conch Sound, May (442).

Campyloneuron Phyllitidis (L.) Presl. In banana holes, not uncommon. Conch Sound, May (566).

Polypodium squamatum L. On trees. Conch Sound, March. Determined by Professor Eaton (406).

*Phymatodes Swartzir (Baker) Underw. In banana holes, rare. Leaves difform, there being a number of short and broad sterile leaves. Conch Sound, May (58r). Same as Wright 799.

Goniopteris Reptans (Sw.) Presl. In banana holes. Conch Sound, May. Determined by Professor D. C. Eaton (583).

Goniopteris REPTANS CORdata. In banana holes. Conch Sound, May. Determined by Professor D. C. Eaton (576).

\section{- Psilotace a}

Psinotum NUdum (L.) Griseb. In hollows in trunks of trees, not common. Cocoanut Point, Andros, April; Fresh Creek, June (5'5).

\section{SPERMATOPHYTA}

\section{CYCADACE}

Zamia sp. "Bay rush." Common in the pines in certain localities. Leaves $15^{-25} \mathrm{~cm}$. in length, leaflets but ten pairs, seldom opposite, thick, with revolute margins, $3 \cdot 5-5 \mathrm{~cm}$. long, 6-9 $\mathrm{mm}$. broad. Seems to be nearest $Z$. pumila L.; resembles Wright 3I93. Stafford Creek, Andros, May (550).

\section{CONIFER E}

Pinus Bahamensis Griseb. Covers large tracts in the interior of both New Providence and Andros. N.P., Jan.; Nicol's Town, April; Conch Sound, May $(84,440)$.

Juniperus Barbadensis L. Not common. Southwest Beach, N.P., Feb.; Nicol's Town, Fresh Creek, June (321, 355).

\footnotetext{
* Species marked with a star were verified by Professor D. C. Eaton, I89I.
} 


\section{TyPHACE $A$}

Typha Domingensis Pers. Nicol's Town, March (353).

\section{NAIADACE $A$}

RUPPIA MARITIMa L. Stafford Creek, Andros, May. Determined by Rev. Thomas Morong (536).

\section{Gramine $\mathbb{E}^{1}$}

Andropogon sp. "Bed grass." Purser Point, Andros, common (659). Specimens not in flower.

Paspalum fimbilatum H. B. K. Nassau, Jan. (i i 8).

Panicum divaricatum L. ? (Not in flower.) Deep Creek, Andros, July (732).

Panicum Proliferum Lam. Fresh Creek, June (620).

Panicum sp. Hog Island, Nassau, Feb. (248).

Cenchrus tribuloides L. "Devil grass." Nassau, Jan.; Deep Creek, July (I48, 7I9).

Sporobolus Virginicus Kunth. Deep Creek, July. On sandy shores (728).

Stenotaphrum Americanum Schrank. Common along shore. Nicol's Town, April (520).

Chloris Swartziana Doell. "Finger grass." Nicol's Town, April (52).

Chaftochloa glauca (L.) Scribn. Fresh Creek, June (6I8).

ERAGRostis Ciliaris (L.) Link. Nassau, Jan. (i67).

Uniola Paniculata L. "Bay rush." Quarantine Cay, Nassau, Feb. (3I4).

Phragmites or ARundo? Only glumes remaining. Near Southwest Beach, N.P., Feb. $\left(3^{r_{5}}\right)$.

Drstichlis sp. "Rabbit grass." Big Cabbage Creek, June. Common on edge of swash. Red Bays (485).

ArTHROSTYLIDIUM CAPILlIFoliuM Griseb.? "Old man's beard." Not in flower. Nassau; common, climbing over shrubs and bushes. Branches leafy, leaves fascicled, wiry, filiform (93).

\footnotetext{
${ }^{1}$ Determined by Dr. Nathaniel L. Britton and Mr. George V. Nash.
} 


\section{CyPerace $\mathbb{E}^{1}$}

Cyperus brunneus Sw. Common. Hog Island, N.P.; Nicol's Town, April (435).

Cyperus ferax Rich. Nassau, Feb. (287).

Cyperus ochraceus Vahl. Nassau, Jan. (I44).

Eleocharis CAMPTOTRICHUS SCHWEINITzII C. B. Clarke. Conch Sound, April (745). Determined by C. B. Clarke, Kew, I89I. "Same as the plant collected in Guadeloupe by Bertero, taken as E. tenuissima by Boeck., called by me as above; also mixed in Wright 3367 from . Cuba."

Eleocharis capitata (Willd.) R. Br. Freshwater Pond, Hog Island, Nassau (247).

Eleocharis ochreata Nees. In banana-holes in the pines. New Providence (327).

Dichromena colorata (L.) A. S. Hitch. Common in the pines, also found in abundance on the savannas at Red Bays, Andros, New Providence, Jan.; Red Bays, April (1oo, 466).

Fimbristylis monostachya (L.) Hassk. Fresh Creek, Andros, June (634).

Fimbristylis spadicea (L.) Vahl. Mastic Point, Andros, June; Purser Point, June $(596,667)$.

RHYNCHOSPORA Microcarpa Baldw. Red Bays, April (493). Same as Eggers 4308 from Bahama.

Rhynchospora cyperoides (Sw.) Mart. Nassau, Feb. (288).

Cladium Jamaicense Crantz. "Saw-grass." Fresh Creek, June (635).

Scleria filiformis Sw. Mastic Point, Andros, June (6o3).

\section{PALMS FROM THE BAHAMAS ${ }^{2}$}

The palms have been neglected so generally in botanical collections that many striking novelties still remain to be secured by those who brave the inconvenience of handling plants so unmanageable by ordinary herbarium methods. The present small series of Bahama palms shows what may be expected in many parts of the tropics, though

Determined by Dr. Nathaniel L. Britton.

${ }^{2}$ The families Sabalaceæ and Arecaceæ were contributed by O. F. Cook, Washington, D.C. 


\section{FLORA OF NEW PROVIDENCE AND ANDROS 137}

for the benefit of botanists who may wish to emulate the example of Dr. and Mrs. Northrop it may be permissible to add that when other material is being secured, ripe fruits, or even the naked seeds, are extremely desirable, and may usually be picked up at the base of the tree long after the fruiting season has passed.

The present list recognizes five palms from the Bahamas, though two of these are not named specifically for lack of adequate material. One may be the species reported by Professor Hitchcock as Thrinax argentea, while our Thrinax Bahamensis may correspond to his $T$. parviflora, though numerous species of this group are doubtless to be found in the Bahama archipelago. Grisebach reported only Sabal umbraculifera, a name no longer tenable. It has been stated also that the Bahamas have a cabbage palm (Euterpe) and a royal palm (Oreo doxa), but these names are also not available for West Indian palms. Moreover, it is not known that specimens exist from which better identifications could be made.

\section{SABALACE $\mathbb{E}$}

\section{Thrinax Bahamensis sp. nov.}

Leaves and inflorescence resembling Coccothrinax jucunda Sargent (Bot. Gaz., 27, 89. I899), but apparently to be associated rather with Thrinax Keyensis Sargent (Bot. Gaz., 27, 86. 1899) in view of the short pedicels, distinctly lobed calyx, broad filaments and short styles.

Petiole $48 \mathrm{~cm}$. long, I $5 \mathrm{~mm}$. broad at base, narrowed to I $2 \mathrm{~mm}$. near the apex; equally convex on both sides, becoming flat above toward the base; segments of middle of leaf about $53 \mathrm{~cm}$. long, and $32 \mathrm{~mm}$. broad; lateral segments reduced to $30 \mathrm{~cm}$. by $5 \mathrm{~mm}$.; texture thin and brittle; venation also closely similar to. C. jucunda, but the surface distinctly less pubescent, or the pubescence much more fugacious, as in other species of true Thrinax; inflorescence with secondary branches slender, subtended by narrow scarious bracts, 8 to ro $\mathrm{mm}$. in length; bracts with a distinct midvein and a pencil of hairs at the tip; pedicels of flowers seldom $\mathrm{I} \mathrm{mm}$. in length, with 6 distinct subtriangular lobes; filaments triangular, often united at base to form a complete cup; stigma truncate or somewhat funnelform, about $0.5 \mathrm{~mm}$. in length.

This species is evidently much smaller in all its parts than Thrinax Keyensis. The comparison of its leaves with those of Coccothrinax jucunda is based on A. H. Curtis's No. 262 from Big Pine Key, which 
seems to correspond well with Sargent's description, though there is the possibility that the leaf and fruit were not taken from the same tree.

Locality. - Big Cabbage Creek, Andros Island, June. Another specimen (257) from Freshwater Pond, Hog Island, N.P., February, consists of a leaf and an old inflorescence, the latter with the spathes still coated in patches with dense white pubescence.

In comparison with Thrinax Ponceana (Bull. Torrey Club, 28, 536. I9or) from Puerto Rico the leaves of the present species are smaller, with the petioles less flattened and more distinctly ribbed on the upper side near the apex. The transverse or oblique veinules are more numerous and more prominent; also the veinules of the lower surface, which lacks the glaucous or waxy covering distinct in $T$. Ponceana.

\section{COCCOTHRINAX sp.}

A single leaf with the form and veination of C.Garberi (Chapman), but somewhat less densely pubescent. Locality: New Providence, Nassau, February, I89o (No. 284).

Mr. Lyster H. Dewey, of the U. S. Department of Agriculture, recently brought back from New Providence Island a leaf probably belonging to a Coccothrinax and popularly called "silver thatch." The leaves are commonly used for weaving into hats and baskets. The trunk seldom, if ever, exceeds about $2.5 \mathrm{~m}$., and is about ${ }_{5} \mathrm{~cm}$. thick. A photograph secured by Mr. Dewey shows that the surface is largely free from leaf bases, and fairly smooth, the leaf scars being but slightly impressed. The diameter seems to be rather uneven, with a tendency to become somewhat thicker in the middle.

\section{Paurotis gen. nov.}

A small, slender palm with spiny petioles like Copernicia, but with only the primary branches of the slender inflorescence subtended by spathes.

Paurotis is probably more nearly related to Serenoa than to Coper nicia, but differs in the larger size, the erect trunk, the stronger ligule, the absence of the ligule-like inferior scales, the presence of a rudimentary midrib, and in the more deeply divided segments. Inflorescence much more slender throughout than in Serenoa; flowers much smaller, with free sepals and short valvate petals. 
The long naked and apically scarious and bilabiate spathes are strikingly different from those of Copernicia. The inflorescence is much longer and more slender than that of Serenoa, but in other respects has greater resemblance than to that of Copernicia. The leaves, on the other hand, are more like Copernicia, though the presence of a true midrib, even if very small, with one or two segments inserted somewhat above the base may be taken as a further sign of affinity with Serenoa.

The present genus will probably accommodate the palm from Puerto Rico (Sintenis, 6512) referred by Professor Drude to Copernicia, but having no spathes on the branches. Grisebach and Wendland described from Cuba, Copernicia Wrightii, which may also belong to Paurotis.

Hitherto Copernicia has been the only known West Indian genus of fan-palms with spiny petioles. The type of Copernicia is $C$. cerifera (Arruda) from Brazil, but the Cuban species of the genus seem to resemble Paurotis even less than the Brazilian, since they have the inflorescence more robust and compact and the spathes more strongly developed. The species listed by the Index Kewensis as Copernicia maritima (Corypha maritima H. B. K.) and Copernicia pumos (Corypha pumos $\mathrm{H}$. B. K.) have smooth petioles according to the original descriptions, and should have been transferred to Thrinax rather than to Copernicia. Although treated as a synonym of Copernicia in the Index Kewensis the generic name Crysophila Blume had priority of publication, as shown by the fact that it is cited by Martius in connection with the original description of Copernicia. It seems probable, however, that Crysophila is distinct from Copernicia as indicated by Drude. Its type, C. nana (H. B. K.), came from the region of Acapulco, Mexico. The petiole is unarmed, and other characters are quite at variance with those of Paurotis.

\section{Paurotis Androsana sp. nov.}

Trunk 3 to $4 \mathrm{~m}$. high, very slender, 5 to $6.5 \mathrm{~cm}$. in diameter, rough with irregular scalelike leaf bases; leaves tufted, flat, orbicular; petioles $5^{2} \mathrm{~cm}$. long, I $5 \mathrm{~mm}$. thick at base, Io to I $2 \mathrm{~mm}$. at apex, not including the spines, $5 \mathrm{~mm}$. thick at base, $3 \mathrm{~mm}$. at apex; upper face moderately concave, subcarinate in the middle distad; lower face strongly convex in the middle, concave on each side; upper surface 


\section{FLORA OF NEW PROVIDENCE AND ANDROS}

with fine longitudinal or oblique impressions, doubtless from the next leaf; lower surface nearly smooth, very finely grooved longitudinally; both surfaces covered with a thin layer of waxy scales; toward the margins are small scattering brownish longitudinal scars, more numerous on the upper side; occasionally there arises from such a scar a narrow scarious ribbon $2 \mathrm{~mm}$. or less in length; these evidently correspond to the peltate scales of the leaf-bases and petioles of Inodes; margins of petioles thickened, smooth, corneous, in color pinkish brown (vinaceous-cinnamon, Ridgway) at base, and dark brown distad; teeth somewhat irregularly placed, usually about $\mathrm{I} \mathrm{cm}$. apart, but sometimes $2 \mathrm{~cm}$. and sometimes close together or with two points; points commonly curved forward, sometimes straight or curved backward; length about $3-5 \mathrm{~mm}$.; size decreasing toward the apex of the petiole, but occasional teeth are mere rudiments; ligule very broadly subtriangular after losing a rather broad, thin, subscarious margin; lateral angles of the ligule coalescing with the margins of the lateral segments as in Thrinax and related genera; each side of this terminal widening of the petiole bears a strongly curved marginal tooth.

Apex of petiole on the under side, broadly triangular, about $5 \mathrm{~mm}$. long. The oblique edges which subtend the insertion of the segments do not, however, meet in the middle; the middle rib is slightly thicker than the others and has one or two segments inserted on each side beyond the apex of the triangle, so that Paurotis may be said to have passed the stage of Thrinax and to have a true midrib.

Leaves about $52 \mathrm{~cm}$. long, composed of about $3^{6}$ segments; middle segments longest, the lateral shortened nearly by half. Segments united for about $20 \mathrm{~cm}$. in the middle of the leaf, but only for $\mathrm{x}$ to 3 $\mathrm{cm}$. at the sides. The segments are split $20 \mathrm{~cm}$. or less from the tips. The margins of the notch are somewhat thickened, but there is no fiber like that of Inodes. The edges of the ribs both above and below are nearly square, and bear along the angles rows of irregularly placed brown scars like those of the margins of the petiole. Both surfaces of the leaf have a thin film of wax. There are from 8 to II longitudinal veinlets larger than the others and I mm. or more apart; between these are similar numbers of finer equal veinlets, the middle one sometimes slightly larger; oblique veinlets distinct, but very fine, not close.

Inflorescence $80-90 \mathrm{~cm}$. long, the main axis bearing from 9 to Io tubular spathes. Base of inflorescence flattened and the lower spathe with compressed, winglike margins. The spathes are open only at the bilabiate apex. 
Locality. - "Loggerhead Creek, Andros, April 22. Not common. Said by negroes to be more common on Eleuthera and islands south." The specimen (5०9) consists of two leaves and two inflorescences with young flowers.

\section{INODES sp.}

The genus Inodes is represented by a single inflorescence. The calyx and corolla are longer than in $I$. Palmetto (Loddiges), the calyx more deeply lobed and the margins of the petals more distinctly papillate-denticulate. The two unequal triangular scales which subtend the flowers are also somewhat larger. These facts indicate specific distinctness, but in the absence of other data the application of a name may be postponed.

Locality. - "In swamps along road near Nassau, February 5." The leaf which bears the same number (284) is here referred to Coccothrinax.

A large-leaved fan-palm from which material for weaving hats and baskets is obtained was noticed by Mr. Lyster H. Dewey growing in swampy places. on New Providence Island. It attains a height of about $5 \mathrm{~m}$. and is possibly different from the palm reported from Cat Island by Professor A. S. Hitchcock (Report Mo. Bot. Gar., 4, 138. r893) as Sabal umbraculifera. This occurs in dry situations, attains a height of about $8 \mathrm{~m}$. and has an inflorescence $1.2 \mathrm{~m}$. long. The berries are $\mathrm{I} 2 \mathrm{~mm}$. in diameter, the seed concave at base and the embryo lateral. As already explained elsewhere (Bull. Torrey Club, 28, 53I. I89I), the name umbraculifera was not available for transfer from Corypha to any American palm, and the application of the next available name Inodes Blackburniana (Glazebrook) has not yet been fixed.

\section{ARECACE $\$$}

\section{Cyclospatheæ, new tribe}

To accommodate the following genus Cyclospathe and Pseudophonix Wendland. The association of the latter with Morenia, Gaussia, and Synechanthus as proposed by Professor Drude, seems to have little warrant.

The Moreniaceæ are monœcious palms with numerous cylindrical partial spathes and sessile flowers arranged in rows. The Cyclo- 
spatheæ are apparently diceious palms with a single complete spathe and pedicellate flowers, without orderly arrangement. The Cyclospatheæ may also be recognized at once by their strongly conduplicate leaf segments, a feature in which they are especially divergent from Chamedorea and the related genera, which have the bases of the segments more open than in most of the pinnate-leaved palms.

\section{Cyclospathe gen. nov.}

A small palm obviously allied to Pseudophænix Wendland, but distinct in having the trunk short and with short internodes, the inflorescence infrafoliar, and the calyx deeply lobed; also in the possession of a curious, short, collar-like spathe completely encircling the main axis of the spadix near the middle of its base.

The leaf segments are strongly folded together like those of Pseudophrnix, but the lower margin is not incurved to bring it against the upper as in Pseudophonix. The "dark conspicuous gland-like excrescences" described by Sargent (Silva, Io, 33) on the sides of the rachis at the base of the pinnæ are evidently much smaller in Cyclospathe, and are mostly confined to the angle of insertion of the upper margin of the pinnæ.

Further differences between $C y$ clospathe and Pseudophonix are discussed in connection with the following description of the type species:

Cyclospathe Northropi sp. nov.

Trunk less than $3 \mathrm{~m}$. in height, about $22 \mathrm{~cm}$. in diameter, slightly bulging in the center; leaf scars distinct, about $2.5 \mathrm{~cm}$. apart; leaf bases very glaucous, also the rachis; rachis distally subtriangular in section, the leaf-bases completely crossing the lateral faces and even prominent above the narrow crest; upper and lower margins of the pinnæ inserted on the same plane at the lateral angles of the rachis; segments are not so strongly plicate as in Pseudophonix, the two edges meeting the rachis about $5 \mathrm{~mm}$. apart, and not thickened and incurved as in the heavier and larger leaf of Pseudophoenix.

The specimens studied have about 20 of the apical pinnæ on each side; lower pinnæ about $47 \mathrm{~cm}$. long by $23 \mathrm{~mm}$. broad; apical pinnæ gradually reduced to $27 \mathrm{~cm}$. by to $\mathrm{mm}$. and smaller, the terminal divisions not completely separated. The distal pinnæ are farther apart than the proximal. 
In Pseudophoenix pinnæ $43 \mathrm{~cm}$. long have a width of $33 \mathrm{~mm}$. The texture of the pinnæ of Cyclospathe is also much thinner and more fragile than in Pseudophonix, and the decurved and thickened anterior margin is broader. The upper surface shows several rather prominent veinules not regularly spaced; below, the veinules are very numerous, close, and equal. The upper surface is smooth and shining, the lower dull and uniform, the space between the veinules being minutely roughened. In Pseudophoenix both surfaces appear more distinctly glaucous.

The spadix at the flowering stage is about $35 \mathrm{~cm}$. long, and about I $2 \mathrm{~mm}$. broad at the flattened base. There are nearly 20 primary branches decreasing in size from the lowest, which is II $\mathrm{cm}$. long and $3 \mathrm{~mm}$. thick at base. The branches are twice or thrice subdivided, the ultimate divisions being about $5 \mathrm{~mm}$. long and bearing solitary flowers at intervals of about I mm., but without regularity of arrangement apparent in the dried specimen. Each branch and flower is subtended by a triangular pointed bract, those of the primary branches being 5 to $8 \mathrm{~mm}$. long, strongly acuminate with a very broad base which at the lowest fork is continued halfway round the stem. A similar growth is probably referred to by Sargent as a "thickened ear-like body" on the upper side of the base of the branches of the inflorescence of Pseudophonix.

The most curious peculiarity of Cyclospathe is a further extension of such a bract or rudimentary spathe to form a complete frill-like band or collar about the middle of the basal stalk of the inflorescence. This structure is about $5 \mathrm{~mm}$. wide, of a light brown color; texture firm, but thin and rather brittle in the dried state.

Flowers (perhaps immature) about $2 \mathrm{~mm}$. long. Calyx tubular forming a pedicel-like base I $\mathrm{mm}$. long; at apex splitting into three triangular slightly imbricate lobes. Corolla thick and fleshy, the petals valvate. No stamens or staminodia were made out, and the indications are that $C y c l o s p a t h e$ is diœcious. Sargent characterizes Pseudophonix as monceious, but apparently without reason, as he says afterward "flowers unknown" and describes only the persistent "staminodia" of the ripe fruit.

Locality. - Andros Island. The leaves (508) were collected on Loggerhead Creek in April, I89o, the inflorescence (67I) on "Big Cabbage Creek, west side" in June. The local name, "hog cabbage 


\section{FLORA OF NEW PROVIDENCE AND ANDROS}

palm," appears with both labels and increases the probability that the specimens were properly associated. In the event of doubt on this point the inflorescence should be treated as the type.

Cocos NUCIFERA L. Common in cultivation.

\section{BROMELIACE}

Tillandsia Balbisiana R. \& S. "Wild pine." Common and variable. Red Bays and Conch Sound, April; Lisbon Creek, June (49I, 528).

TillandSIA BUlbosa Hook. "Wild onion." On mangroves in the swash. Purser Point, June. Not common (654).

Tililandsia fasciculata Swartz. "Dog-drink-water." Common. Nicol's Town, Red Bays, April (439).

Tillandsiaf lexuosa Sw. Nicol's Town, March. Like Blodgett's specimen from Key West; not like Wright 327I (369).

Tillandsia Recurvata L. Not common. Fresh Creek, Kemp Sound, Andros, June (6I 7 ).

TILlandsia UTRICUlata L. More than $\mathrm{I} .5 \mathrm{~m}$. in height. Flowers whitish. Larger than any specimens examined. Fresh Creek, June (6I2).

\section{COMMELINACE I}

Commelina nudiflora L. Nassau, Jan. (7).

RHÆA DISCOLOR (L'Her.) Hance. (Tradescantia discolor L'Her.) Nassau, Jan.; Conch Sound, April (26).

\section{LILIACE}

\section{Aletris bracteata sp. nov.}

Roots numerous, fibrous; basal leaves numerous, spreading, grayish green, lanceolate or linear-lanceolate, apex acuminate, rigid, narrowed at the base, 6-10 $\mathrm{cm}$. long, 6-1o $\mathrm{mm}$. wide; scape 5-6 dm. in height, bearing small, scattered bract-like leaves; raceme erect, many-flowered, pedicels about I mm. in length, bracts subulate, 4-6 $\mathrm{mm}$. in length, almost equaling the corolla; perianth tubular-oblong, sometimes slightly contracted below the lobes, white, 6-8 $\mathrm{mm}$. long, about $3 \mathrm{~mm}$. wide, slightly roughish on the outside; lobes six, oblonglanceolate, about one-fourth as long as the tube; stamens included, 


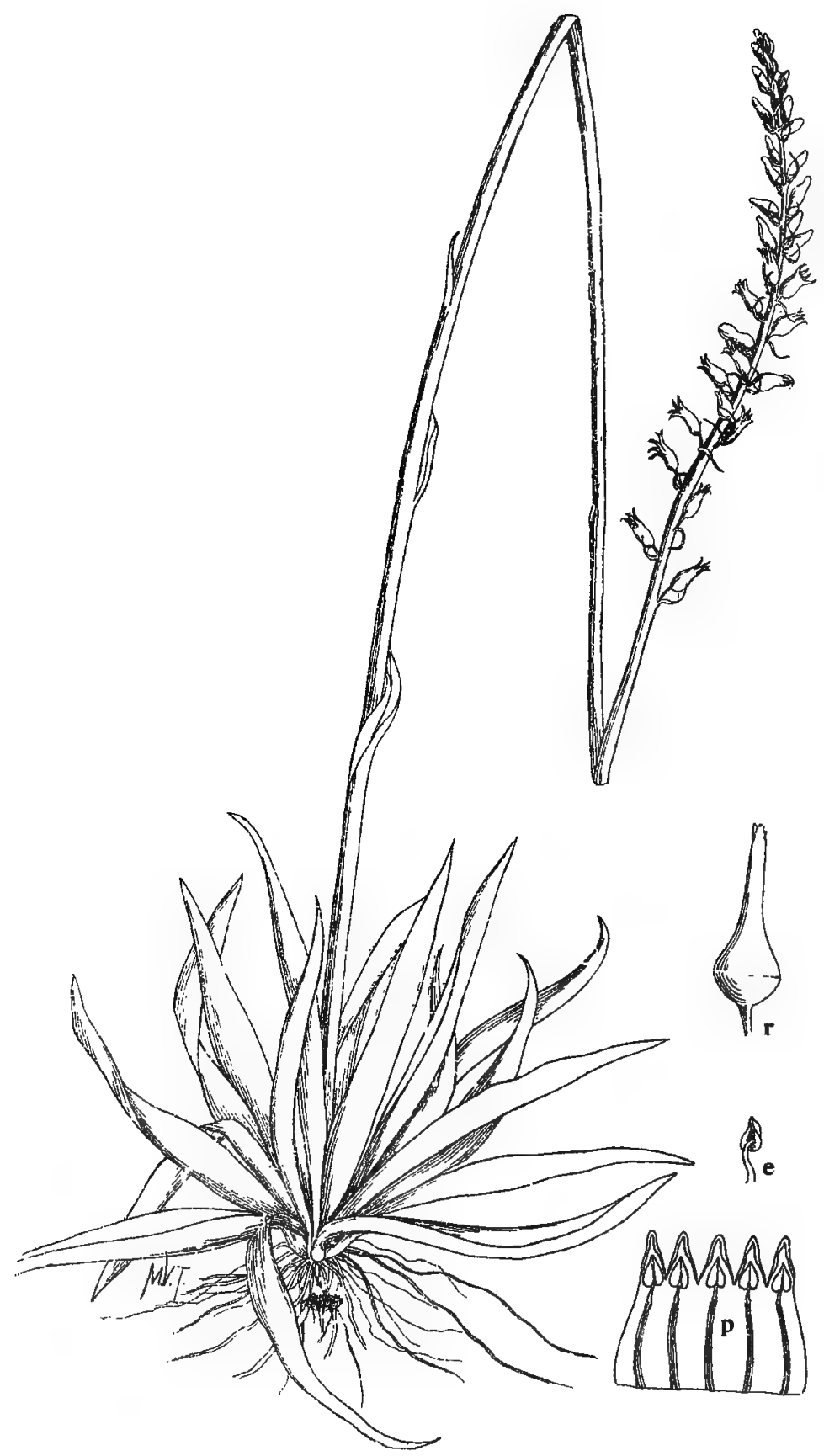

ALETRIS BROCTEATA 

oblong-lanceolate, apiculate at the apex, longer than the filaments; pistil included; ovary adherent to the perianth for the lower half, style flattened and broad at the base, slightly three-cleft above: stigmas three; ovules numerous; fruit not seen $(463)$.

Common on the savannas near Red Bays, Andros, April.

Closely related to $A$. farinosa L., but differs in the grayish green longer and narrower leaves, with more rigid apex, the longer bracts and the broader flattened style.

Plate I. Aletris bracteata. Entire plant $\times \frac{5}{6} ; p$, interior of perianth; $e$, stamen; $r$, pistil.

\section{SMILACACE $\mathbb{E}$}

Smilax auriculata Walt. New Providence, March; Conch Sound, April, Purser Point, June. Common. Peduncles longer than pedicels $(339,527)$.

Smilax Havanensis Jacq. "Saw-brier." Nassau, Jan.; Purser Point, Deep Creek, June.

Specimens from Nassau and Purser Point unarmed; Deep Creek specimens have prickles on midrib of many of the leaves as well as on margin (59, 663).

SmILAX sp.? Unarmed or with very few prickles, branchlets angular, leaves mostly broadest at the apex, obovate or oval, $4-5 \mathrm{~cm}$. long, 3-4 cm. wide, thickish, smooth, apex retuse, mucronate, base acute, margin entire, veins prominulous on both sides; tendrils usually inserted a little below the middle of the petiole: staminate flowers, peduncles longer than the petioles, flower-buds globose, petals elliptical, blunt, 3-4 mm.; anthers oblong. Pistillate flowers not seen. Collected on border of swash at Purser Point, Andros, June (664).

\section{AMARYLIIDACE $\mathbb{E}$}

Agave RIgIDA Mill. "Bamboo." On savannas at Red Bays, Aprii. Not common. Flowers bright yellow. Determined by $\mathrm{Mr}$. J. G. Baker, at Kew, I897.

Agave Rigida Sisalana Engelm. "Sisal." Cultivated and escaped. Nassau, Jan. (I64).

Furcroa Cubensis Haw. Specimens imperfect. Nassau, Jan. (203). 


\section{Hymenocallis arenicola sp. nov.}

Bulb large; leaves erect-spreading, fleshy, smooth, dark green, lance-oblong, $4-5.5 \mathrm{dm}$. in length, $4-5.5 \mathrm{~cm}$. wide, rounded at the apex and narrowing at the base to $2.5-3.5 \mathrm{~cm}$.; scape almost equaling the leaves; bracts large, scarious, ovate or lanceolate, $3^{-6} \mathrm{~cm}$. long, $\mathrm{I}-2.5$ $\mathrm{cm}$. wide; flowers seven to thirteen in a sessile umbel, white, fragment; tube filiform, white, $5-7 \mathrm{~cm}$. long, shorter than the lobes; divisions of the perianth 8 -I I cm., narrowly linear, recurved; crown infundibular, $3^{-4} \mathrm{~cm}$. in length, less than half as long as the stamens, teeth prolonged into the filaments; anthers linear, $1.5 \mathrm{~cm}$. long, attached below the middle; ovary ovate, three-celled, about $2 \mathrm{~cm}$. long; style filiform, longer than the stamens, about equaling the lobes of the perianth; stigma small, capitate.

Common on sandy beaches on the eastern side of Andros. Collected at Nicol's Town, April; Fresh Creek and Deep Creek, June. Most nearly related to $H$. Caribaa Herb. (5r9).

Plate 2. Hymenocallis arenicola, inflorescence and leaf $\times \frac{8}{4}$.

Hypoxis Juncea Smith. On border of swash. Red Bays, April, May. Not common (476). The same as Wright 3745 , except that it is smaller and more delicate.

\section{DIOSCOREACE}

Rajania Hastata L. Common on both islands. Nassau, Jan.; Deep Creek, June. Leaves very slender, I cm. in width, or less above the base, otherwise like Wright, Cuba, I7 I2 (203).

\section{ORCHIDACE E}

Bletia verecunda R. Br. Common in the pines on both islands and on the border of the swash on west side of Andros. Nassau, Jan.; Red Bays, March. There seems to be no distinction between this species and $B$. purpurea DC., reported as endemic in the Bahamas (9I). Same as 365 Plant. Guat., J. Donnell Smith.

Epidendrum fucatum Lindl. "Wild Indian." Common in the coppet. Conch Sound, May; Mastic Point, June; Mars Bay, July $\left(584,7\right.$ I I ). Same as Wright $33^{29}$.

Epidendrum nocturnum L. Conch Sound, March. In fruit only (4I4). 


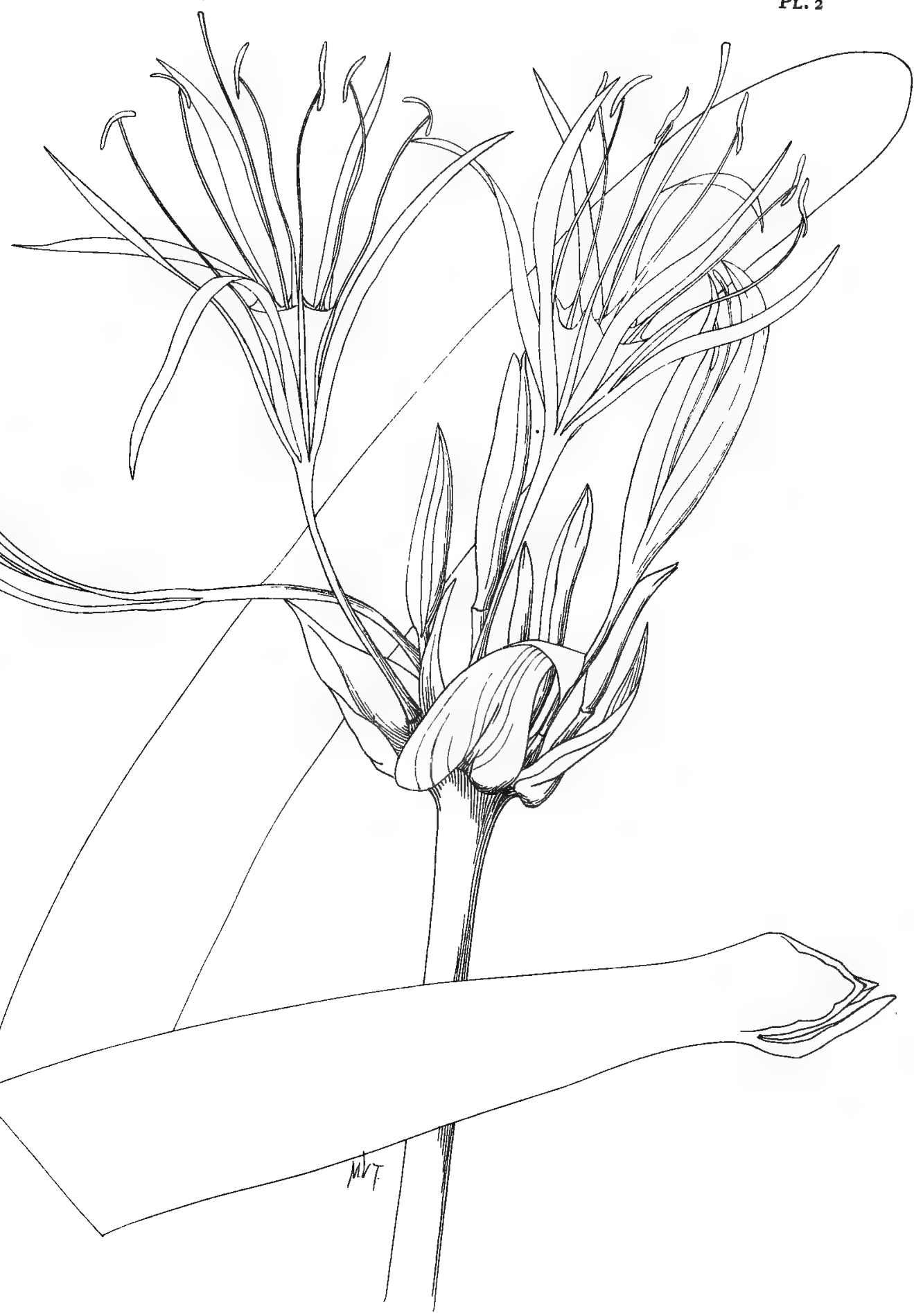

HYMENOCALLIS ARENICOLA 

EPIDENDRUM ODORATISSIMUM Lindl. Growing in sandy soil, near the shore, occasionally on trees near ground, in that case being smaller; flowers very fragrant, having an odor like birch. Collected at Calabash Cay, near Stafford Creek, Andros, June (606).

Epidendrum Phøniceum Lindl. "Wild Indian." Not uncommon in the coppet. Fresh Creek, June (609). Differs from Rugel $8 \mathrm{I} 4$, in having the bracts much shorter, $5^{-7} \mathrm{~mm}$. long, more obtuse, and the lip more strongly crispate.

EPIDENDRUM sp.? Single specimen from Stafford Creek, June. Aërial, tubers small, one-phyllous, leaf $5-6 \mathrm{~cm}$. in length, linear-oblong, crenulate: scape $3 \mathrm{dm}$. in height, few-flowered: flowers white, $2 \mathrm{~cm}$. long, divisions of perigone narrow (674).

EPIDENDRUm? In fruit only. Aërial, tuber two-leaved, leaves $3 \mathrm{dm}$. in length, $5 \mathrm{~mm}$. in width : capsule oblong, $2 \mathrm{~cm}$. long, 8-1o $\mathrm{mm}$. wide. In the pines, Lisbon Creek, Andros, June (679).

Broughtonia liLacina Henfr. (Laliopsis Domingensis Lindl.) Common in the coppet. Cocoanut Point, April; Fresh Creek, Lisbon Creek, June $(437,448,546)$.

Polystachya Luteola Hook. On trees, in coppet. Conch Sound, April (525).

Polystachya sp.? Close to $P$. luteola, but much smaller; leaves I 2-I $4 \mathrm{~cm}$. long, I cm. broad : flowers 5-7 mm. long, lip three-lobed, callous at base, column very short. Conch Sound, March and May $(4 \circ 7)$.

Govenia utriculata Lindl. In fruit only. Conch Sound, March. Determined by Mr. J. M. Greenman, at Cambridge (4I8).

ONCIDIUM SYLVESTRE Lindl.? Not uncommon under the pines. Conch Sound and London Creek, May. It has the habit of $O$. sylvestre, but the white pink-spotted flowers are smaller and leaves shorter; lip 8-Io $\mathrm{mm}$. in width: leaves 8-I2 cm. long (543).

Oncidium Variegatum Sw. On trees, Conch Sound, May. Leaves longer and narrower (3-4 mm. in width), than in Wright 668 and Eggers 1796 from St. Domingo (587).

Oncidium sp. On trees, rare. Fresh Creek, June. Near $O$. variegatum Sw. Flowers deeply spotted, divisions of perigone narrower, $2-4 \mathrm{~mm}$. wide, abruptly pointed : leaves $6-8 \mathrm{~mm}$. wide (647).

ONCIDIUM sp.? Near O. sphacelatum Lindl. Single specimen from Mastic Point, June; terrestrial, I.5 m. in height; scape lateral; 


\section{FLORA OF NEW PROVIDENCE AND ANDROS}

greenish yellow flowers panicled; leaves equitant, recurved, rosulate from flattened tubers (602). No. $75^{\circ}$ collected at Mars Bay, Andros, in July is probably a smaller specimen of the same species and No. 405 from Conch Sound, an Oncidium in fruit only, may perhaps be referred to the same species.

Vanilla articulata sp. nov. "Link-vine," "wormwood"

A tall climber with aërial roots, growing over trees and shrubs, aphyllous; stems jointed, joints fleshy, smooth, subangular, 2-3 dm. in length; flowers in short axillary spikes, 6-I2 flowered; bracts broadly ovate or triangular, blunt, $5 \mathrm{~mm}$. in length; flowers about 6 $\mathrm{cm}$. long, fleshy, white with faint pinkish tinge, parts of perigone jointed at the base; sepals erect, spreading, fleshy, oblanceolate, involute at the tip, $3-4 \mathrm{~cm}$. long, about $\mathrm{r} \mathrm{cm}$. wide; petals oblanceolate or spatulate, equaling the sepals but thinner, keeled on the back; lip adnate to the column more than two-thirds of the way, convolute, broadly obovate or triangular, about $3 \mathrm{~cm}$. in width, channeled on the back, three-lobed, lobes obtuse, crispate, lateral lobes papillose below, central lobe sparingly crested above, bearded below (thick tuft of cilia 5-6 mm. long), column elongated, about $2.5 \mathrm{~cm}$.; anther terminal jointed at the base, pollinia two; stigma shortly transverse: ovary fleshy, flattened, sometimes slightly two-edged, incurved, $3-3.5 \mathrm{~cm}$. long, $5 \mathrm{~mm}$. wide; capsule elongated.

Collected on both islands, not common. New Providence, Feb.; in bloom, July; London Creek, May; Deep Creek, June (545).

PLATE 3. Vanilla articulata. Cluster of flowers; $e$, lip; $a, n$, sepals; $d$, petal; $o$, column, side view; $v$, column, front view; $m$, cross section of buds.

Cranichis sp.? Near C. tenuis Reich. Leaves lanceolate, $6-8 \mathrm{~cm}$. in length; petioles equaling or exceeding the leaves; scape very slender, few-flowered, $22 \mathrm{~cm}$. in length, few small sheathing scales. Two specimens only, Conch Sound, May (567).

Cranichis sp.? In fruit, possibly C. muscosa Sw., but the scape is much more densely flowered than in Wright 620 from Cuba. Conch Sound, March (4I7).

STENORHYNCHUS ORCHIOIDES Rich. Not common. Flowers greenish. Conch Sound, May (4I2).

Gyrostachys Peruviana (Aubl.) Kuntze? Common and variable. Collected on both sides of Andros, Conch Sound, March; Red Bays, April $(399,574)$. Bracts more acuminate than in Wright 3296. (Spiranthes tortilis Rich.?) 

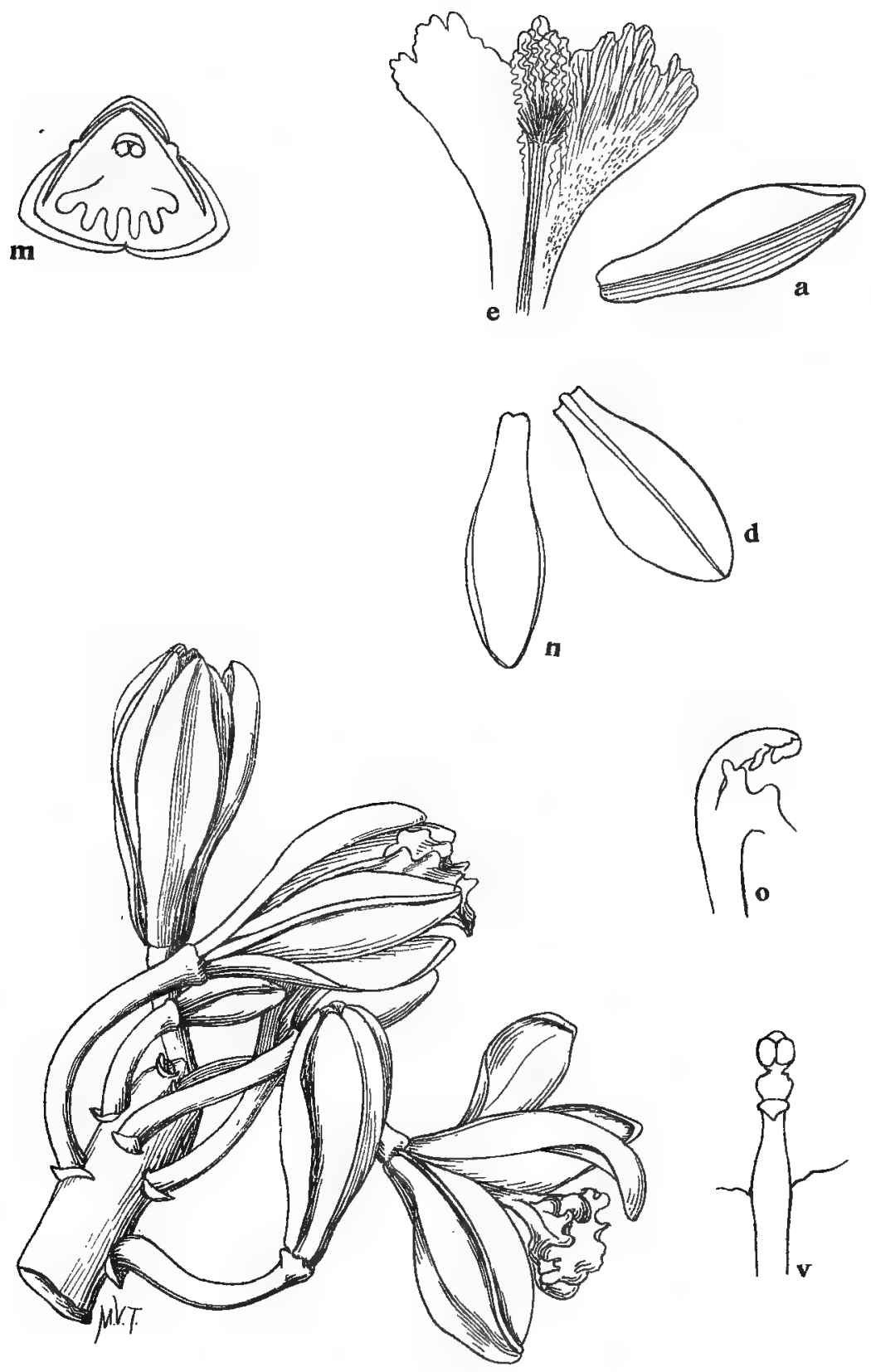

VANILLA ARTICULATA 

Limodorum TUBERosum L. Common on savannas on west side of Andros. Variable, some specimens approach L. graminifolium (Ell.) Small. Red Bays, April, May (430-500). Same as Wright $33^{1} 7$ from Cuba.

\section{Casuarinace 压}

Casuarina equisetifolia Forst. "Spanish cedar." Nassau, Feb. Common in cultivation $(297,454)$. 454 was collected on the west shore of Andros, miles from any settlement. It is also reported from the Florida Keys.

\section{MYRICACEA}

Myrica cerifera L. "Wax-berry," "mickle-berry." Common on Andros. Nicol's Town, March; Lisbon Creek, July (357).

\section{MORACE}

Ficus Dimidiata Griseb. "Fig tree." Nassau, Jan.; Nicol's Town, March (II9, 377, 378). II9 is the same as Wright 542. 377 and 378 are probably $F$. dimidiata with young leaves.

Ficus PEdunculata Willd. "Fig tree." Nassau, Jan. (46). Same as Wright I684.

Ficus Pertusa L. Mastic Point, Andros, May (586). Same as Wright 545 .

Frcus Indica L. "Banyan." Cultivated, Nassau, Jan. (295). ARTOCARPUS INCISA L. f. "Breadfruit." Cultivated (26I).

\section{ULMACE $\approx$}

Trema Lima (Lam.) A. S. Hitch.? (Sponia Lamarckiana Desc.) "Wild birch," "wild fig." Common in the coppet at Red Bays (Lewis Coppet), April; Deep Creek, June.

A low tree, not tortuous branching. In general appearance and mode of branching seems between $T$. mollis Desc. and T. Lima. The leaves are larger than any specimen of $T$. Lima examined, $4-5 \mathrm{~cm}$. long, $.5^{-2.5} \mathrm{~cm}$. broad; upper surface very scabrous, apex acute. It is the same as Cooper 2I from New Providence and Eggers 2326, unnamed $(485,683)$.

\section{URTICACE $A$}

Fleurya estuans Gaud. Nassau, Jan. (30).

Adicea microphylla (Sw.) Kuntze. Nassau, Jan. (29). 


\section{LORANTHACE E}

Déndropemon emarginatus (Sw.) Steud. Nicol's Town, March. On fig, gum elemi, etc. (373). Agrees with Wright I303, except that racemes are shorter and the pedicels longer.

Dendropemon sp. "Mistletoe." Mars Bay, Andros; on Peltophorum, July (7I3). Plants smooth, branchlets and peduncles much compressed.

Phoradendron racemosum Krug \& Urban. "Snake-root," "big man." Deep Creek, June; on Nectandra (704). Same as Eggers I 74I and Wright I252 p. p.

Phoradendron Northropiæ Urban, sp. nov.

Ramis teretibus v. junioribus plus minus compressis, superne di-v. -trichotomis: vaginis cataphyllaribus ad omnia internodia supra basin obviis solitariis, raro binis: foliis obovatis v. breviter obovatis antice rotundatis $v$. sub-truncatis, plerumque late emarginatis, basi sensim v. satis abrupte in petiolum $2-6 \mathrm{~mm}$. longum angustatis, $3-7 \mathrm{~cm}$. longis, $2.5-4 \mathrm{~cm}$. latis, vix dimidio usque duplo longioribus quam latioribus, partissime et obsolete pinnatinervibus, crasse coriaceis; spicis ad nodos pluribus lateralibus, $1.5-2.5 \mathrm{~cm}$. longis ; $4-6$ articulatis : articulis androgynis, IO-I 4 floris $\mathrm{V}$. $\mathrm{I}-2$ supremis 6-2-floris; floribus in seriebus 4 depositis, imparibus 2 sub apice cujusque articuli adjectis, hisve masculis, cæteris femineis, baccis non visis.

Rami inferne $3-5 \mathrm{~mm}$. crassi, glaberrimi, internodiis 4-1o $\mathrm{cm}$. longis. Folia in sicco olivacea v. brunnescentia, nervis lateralibus utrinque plerumque 2, altero supra basin, altero ad medium e nervo medio abeunte, supra vix, subtus paullo melius conspicuo. Spicæ interdum revera ex axillis euphyllorum solitariæ, sed utrinque accessoriis autæ ideoque pro axilla specie ternæ, sed plerumque ad nodos vetustos inordinate plures, ex axillis squamarum minutarum orientes, $3-5 \mathrm{~mm}$. longe pedunculatæ.

Hab. in Ins. Bahamas, Andros Island and Conch Sound and Lisbon Creek, in June flor. Northrop No. 55 (in Mimusops depressa Pierre).

Plate 4. Phoradendron Northropia. Portion of plant $\times \frac{3}{4} ; a$, inflorescence.

\section{ARISTOLOCHIACE $\mathbb{E}$}

Aristolochia Passifloræfolia Rich. Conch Sound, May. In the pines (568). Same as Wright 3665 .

Aristolochia pentandra L. Nicol's Town, March (385). Same as specimens of Garber and of Curtiss from South Florida. 


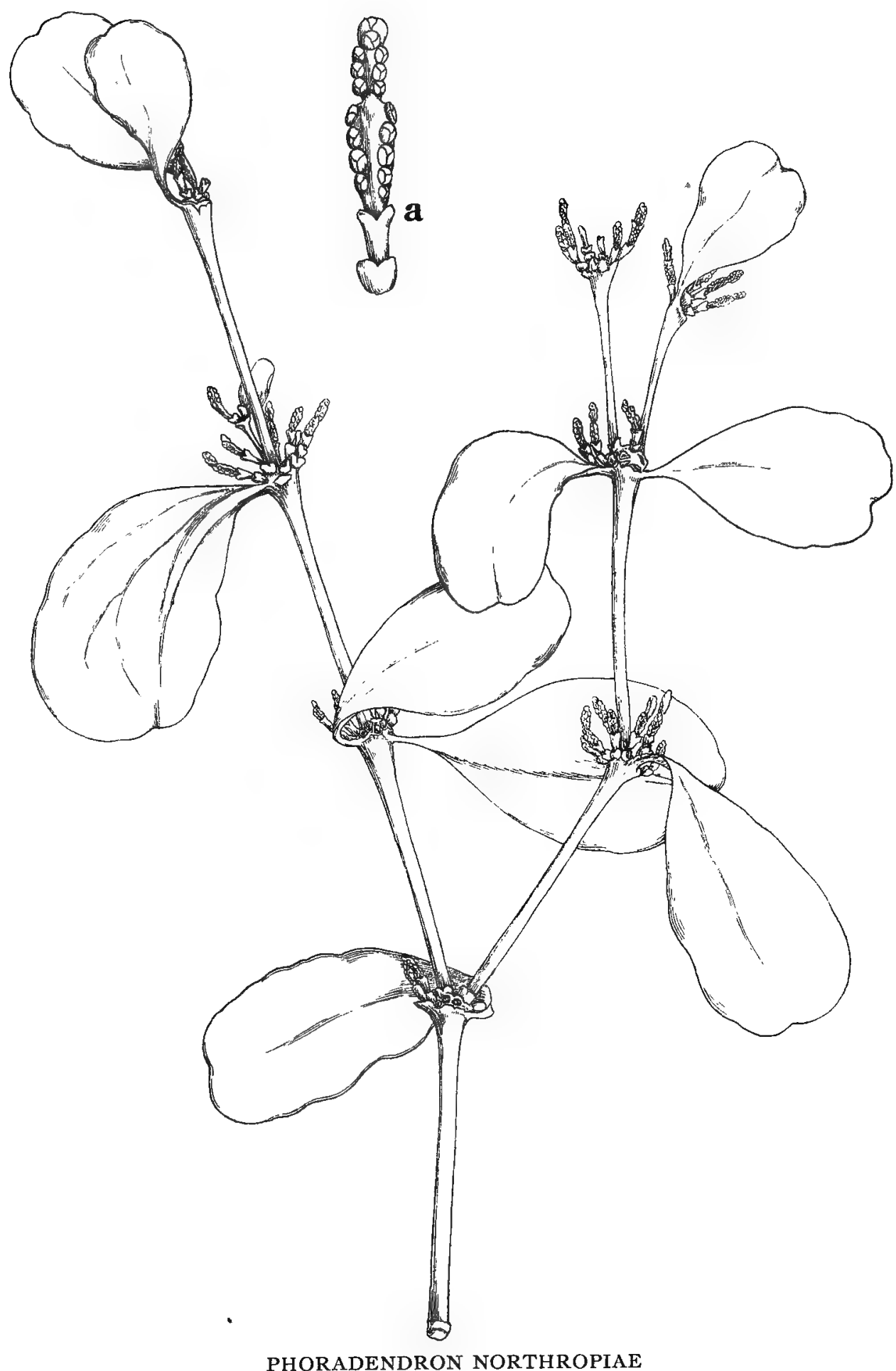





\section{Polygonace $A$}

Coccolobis diversifolia Jacq. Nassau, Jan. (I43). Determined at Kew by Dr. N. L. Britton. Same as Brace I42 "var. foliis minoribus" Lindau.

Coccolobis Retusa Griseb. "Pigeon-plum." Deep Creek, June (705); Purser Point,. June (662); low in fruit. Same as Wright $225^{2}$.

Coccolobis tenuifolia L. Nicol's Town, April (443). Determined at Kew by Dr. N. L. Britton. Same as Wright 3368. Same as Brace I5I, I93, and 205.

Coccolobis uvifera (L.) Jacq. "Sea-grape." Nassau, Jan. Common everywhere along north shore of New Providence and east shore of Andros (80).

CoccolobIS WRIGHTII Lindau. "Pigeon-plum." Deep Creek, July (72I). Determined at Kew by Dr. N. L. Britton. Same as Wright 1395 .

Coccolobis obtusifolia Jacq. "Pigeon-plum." Deep Creek, June (7०6). Determined at Kew by Dr. Britton to be the same as Eggers 4486, which according to Lindau is $C$. microstachya ovalifolia Meisn.

Polygonum Portoricense Bertero. ( $P$. densiflorum Meisn.) Fresh Creek, June. Not common (62I).

Antigonum leptopus H. \& A. Common in cultivation. Nassau and Mastic Point, June (604).

\section{Chenopodiace \&}

Atriplex Cristata H. B. K. Deep Creek, June (709).

Salicornia AMBIGUA Michx. Common along the east coast. Nassau, Jan. (I7I).

SALICORNIA BigeloviI Torr. (S. mucronata Bigel.) In the swash on the west side of Andros. Wide Opening, June (669). $3 \mathrm{dm}$. in height, branches very strict.

Dondia fRuticosa (Forsk.) (Suceda.) Red Bays, April (455). 7-8 dm. in height, rigid, much branched.

Dondia LINEARIs (Ell.) Millsp. Common. Nassau, Jan. (I94). 


\section{FLORA OF NEW PROVIDENCE AND ANDROS}

\section{AMARANTACE $\notin$}

Aiternanthera muscoides Sw. Lake Waterloo, Nassau, Jan. (I5O).

Alternanthera paronchyiordes St. Hil. Nassau, Jan. (I97). Same as Eggers 257 I (not named specifically), except that the plant is more compact and the petioles shorter, 3-4 $\mathrm{mm}$.

Lithophila vermicularis (L.) Uline. "Sampire." Ft. Montagu, Nassau, Jan. Common on sandy shores (I47).

Iresine paniculata (L.) Kuntze. (I. celosioides L.) "Newburn weed." Nicol's Town, March; Stafford Creek, June (362).

\section{BATIDE}

Batis maritima L. Mastic Point, May; Cormorant Cay, Andros, June (595).

\section{Phytolaccace}

Rivina HUMILIS gLabra L. Common on N.P. and Andros. Nassau, Jan. (20).

Phytolacca octandra L. " Poke-bush." Nicol's Town, March (354).

\section{NYCTAGINACE $\mathbb{E}$}

Mirabilis Jalapa L. "Four-o'clock." Naturalized in Nassau, Jan.

BoerhaAvia erecta L. Near caves, New Providence, Feb. (280). Boerhaavia Paniculata Rich. Mastic Point, Andros, May (732). Boerhaavia scandens L. Near caves, New Providence, Feb. (28I).

Pisonia aculeata L. "Cockspur." Common in the coppet of both islands. Nassau, Jan. (73, 196).

Pisonia obtusata Sw. In the coppet, Nicol's Town, April (517). Same as a specimen of Blodgett's from Key West, named by Torrey.

Pisonda Rotundata Griseb. In the coppet, not common. Fresh Creek, June (636). Same as Wright 3369, also specimens of Blodgett's from Pine Key, Fla.

Bougainvillea spectabilis Poir. Common in cultivation at Nassau (I 42 ). 


\section{AizoACE}

Sesuvium portulacastrum L. Common on sandy beaches on both islands, variable. Nassau, Jan. (I49).

\section{PORTULACACE}

Portulaca oleracea L. Common prostrate form, collected at Nassau, Jan.

Portulaca oleracea L. var.? Plants $2-2.5 \mathrm{dm}$. high, ascending, nearly erect; leaves $\mathrm{I}-2.25 \mathrm{~cm}$. in length, obtuse or sometimes retuse, axils shortly and sparsely pilose: flowers larger than in the common form, clustered: petals $4-5 \mathrm{~mm}$.: sepals strongly carinate-winged: style 3-4-parted: seeds small, less than $.5 \mathrm{~mm}$., rugose. Found growing abundantly on Cormorant Cay in the Northern Bight, west side of Andros, June (658).

Portulaca halmoides L. Conch Sound, May. Common on rocks $(580)$.

\section{ANONACEA}

Anona Palustris L. "Custard apple." Not uncommon in swampy parts of the coppet. Conch Sound, March (408). Same as Rugel 7 Io.

Anona squamosa L. "Sugar apple.." Nicol's Town, cultivated (5'3).

\section{RANUNCULACEA}

Clematis dioica L. Collected by Mr. Alexander Keith at Conch Sound, I894. Not common (742).

\section{LAURACEE}

NectandRa SANGUINea Rottb. "Sweet torchwood." Common in the coppet. Conch Sound, Red Bays, April; Fresh Creek, June $\left(487,6 \mathrm{r}_{3}\right)$. Agrees with Wright 484 except that the leaves are narrower $(2.5-3 \mathrm{~cm}$.).

CASSYTHA FILIFORMis L. Common on shrubs and low trees. Nassau, Jan. (78, 104, 512). A more slender form with yellow stems was found on low grasses at Loggerhead Creek on the west side of Andros, also found on Rose Island, N.P. (266). 


\section{FLORA OF NEW PROVIDENCE AND ANDROS}

Persea Persea (L.) Cockerell. "Avocado pear." Common in cultivation. Nicol's Town, March (37I).

\section{PAPAVERACE $\mathbb{E}$}

Argemone Mexicana L. Common about Nassau, Jan. (5I).

\section{CRUCIFER 压}

Brassica ARvensis (L.) B. S. P. (B. Sinapistrum Boiss). Nassau, Jan..(225). Leaves almost entire.

Lepidium Virginicum L. Nassau, Jan. (I40).

Cakile equalis L'Her. Common on sandy beaches. Salt Cay, Feb. $(88,278)$. Same as Wright 1863 .

\section{CAPPARIDACE}

Pedicellaria pentaphylla (L.) Schrank. "Wild mustard." Fresh Creek, June $\left(6_{30}\right)$.

\section{Crassulace 2}

Bryophyllum Pinnatum (Lam.) S. Kurz. (B. calycinum Salisb.) "Live-for-ever." Nassau, Jan.; also on Andros (I99).

\section{ROSACE $A$}

Chrysobalanus Icaco L. "Pigeon plum." Common on sandy shores. Nassau, Jan.; Fresh Creek, June. Many specimens at latter locality had white drupes (II5).

\section{Mimosace $\Phi$}

ACACIA CHORIOPhylla Benth. "Cinnecord." Common in the pines on both islands. New Providence, Feb. ; Nicol's Town, March $(3 \mathrm{I} 2,364)$.

ACacia Farnesiana (L.) Willd. Nassau, Jan. (44).

ACUAN DEPREsSA (Kunth.) Kuntze. (Desmanthus.) Red Bays, April (495).

Acuan virgata (Willd.) Kuntze. (Desmanthus.) Mastic Point, May (73I).

Mimosa pudica L. "Sensitive plant." Collected by Mr. Keith, I891. Uncommon on Andros, but said to be abundant on Eleuthera. Mastic Point (735). 



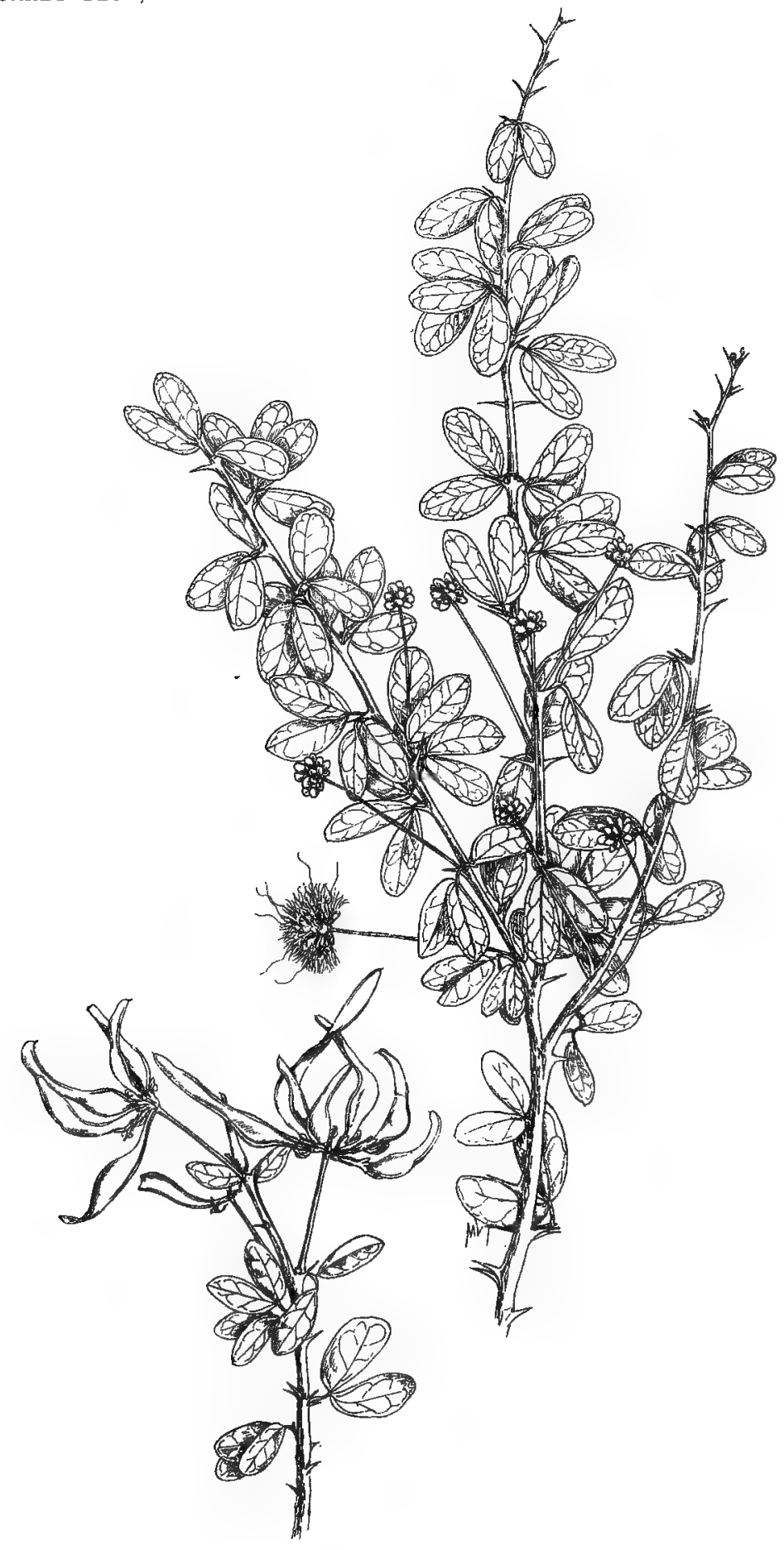

PITHECOLOBIUM BAHAMENSE 
Leucana glauca (L.) Benth. "Jumby-bean." Nassau, Jan., Feb.; Bearing Point, Andros, June (43, 282, 657). Nos. 282 and 657 were shrubs, $1.5-2 \mathrm{~m}$. in height.

Lysiloma paucifoliola (DC.) A. S. Hitch. (Sabicu Benth.) "Horseflesh," "sabicu." Common in the coppet; one of the most valuable timber trees. Nicol's Town, April; Deep Creek, June (434).

Lysiloma Bahamensis Benth. "Wild tamarind." New Providence, Feb. (309). Same as Wright 3542.

Calliandra rormosa Benth. Hog Island, Nassau, Feb. (255). In fruit only. Determined by Dr. B. L. Robinson at Gray herbarium.

Pithecolobium Hystrix Benth. (P. calliandrafolium Wright.) In the pines, not common. Conch Sound, May; Deep Creek, June (575). It is the same as Wright $240 \mathrm{I}$.

Pithecolobium Unguis-Cati (L.) Benth. "Ram's horn." Common near the shore on both islands. Nassau, Jan.; Cocoanut Point; Andros, April $(66,235,449) .66$, collected at Nassau, has the leaves two-jugal and agrees with Eggers ( 3830$)$.

Pithecolobium Bahamense sp. nov. "Ram's horn"

A shrub, I.5-2 m. in height, with slender, drooping branches, armed with delicate, stipular spines, $3-7 \mathrm{~mm}$. in length; leaves bipinnate, pinnæ one-jugal, leaflets one-jugal; petiole $\mathrm{I}-4 \mathrm{~mm}$. in length, petiolules I- $3 \mathrm{~mm}$., channeled and with a single stipitate gland at the base, leaflets oblong to oblanceolate or obovate, $1.25-2 \mathrm{~cm}$. long, a little over half as broad, obtuse or mucronate at the apex, oblique and slightly unequal at the base, chartaceous, glabrous, shining above, entire, subsessile with a stipitate gland at base ; inflorescence capitate, manyflowered; peduncles $2-3 \mathrm{~cm}$. in length, much exceeding the leaves; calyx tubular, less than one-half the length of the corolla with five ovate acute lobes; corolla crimson, tubular, 3-5 mm. in length, five-lobed, lobes acute, about one-half as long as the tube; stamens numerous, crimson, exserted, more than twice the length of the corolla; anthers small, rounded; ovary stipitate: style much exserted, about $2 \mathrm{~cm}$. in length, four times as long as the corolla; stigma small; immature fruit compressed, slightly curved, puberulent; mature fruit $9 \mathrm{~cm}$. in length, I cm. in width, dark brown, curved; seeds ariled.

Collected in fruit near Nassau in January, and in flower in the coppet at Mastic Point, Andros, in June (605). The plant belongs to the section Unguis-cati and is related to $P$. circinale Benth.

Plate 5. Pithecolobium Bahamense. Portions of plant in flower and in immature fruit. $\times \frac{5}{7}$. 


\section{CASALPINACE A}

Cassia BaHamensis Mill. "Stinking pea." New Providence Jan. (IO3).

CAssia BIFlora L. Nassau, Jan. Leaflets strongly emarginate (55).

Cassia ligustrina L. Common. Nassau, Jan.; Conch Sound, March ( 123,422$)$. Same as Wright $x$ I9o.

Cassia mimosomes L. Nassau, Jan. Pods $2-2.5 \mathrm{~cm}$. long, very hairy (I34).

Cassia occidentalis L. Nassau, Jan. (IO5).

Cassia polyadena DC. Nicol's Town, March. In the pines, strict and unbranched, $7-9 \mathrm{~cm}$. in height, not as pubescent as Wright 2376.

Cassia villosa Mill. Nassau, Jan. Determined by Miss Anna Murray Vail at Columbia herbarium (I4).

\section{Cassia Caribæa sp. nov.}

Shrubby, 6-9 dm. in height, stem gray, smooth; leaves $2-3.5 \mathrm{~cm}$. long, with from two to four pairs of leaflets, mostly three; petiole 2-5 nIm. long, channeled; a stipitate gland between the leaflets or slightly below (often wanting between the lowest pair); leaflets sessile, elliptical, I. $5^{-2} \mathrm{~cm}$. long, about one-third as wide, unequal and oblique at the base, apex mucronate, margin entire, thickish, glabrous, shining above, resinous-dotted below; veins numerous, parallel and prominent; stipules about $3 \mathrm{~mm}$. in length, subulate, subspinescent, ribbed and often with appressed white hairs on the margin, persistent; flowers large, solitary, axillary; peduncle $2-3 \mathrm{~cm}$. long; calyx deciduous: sepals lanceolate, acuminate, about I cm. long, the three outer ones keeled, keel pilose, petals yellow, oblanceolate or obovate, nearly twice as long as the sepals and about I $\mathrm{cm}$. in width; stamens Io, the three upper difform, anthers linear, puberulous along the furrow, bursting at the top by two short clefts; ovary about $5 \mathrm{~mm}$. in length, shorter than the flattened style and covered with appressed white hairs; legume purplish brown, linear-oblong, $3-5.5 \mathrm{~cm}$. long, 5-7 mm. wide, bivalved, compressed, mucronate, with a few scattered hairs: seeds about eight, oblong, compressed.

Collected in the coppet at Fresh Creek, Andros, June Io, most closely related to $C$. lineata Sw. $\left(63_{3} 8\right)$.

Plate 6. Cassia Caribøa. Portions of plant, natural size; I, leaflet. 


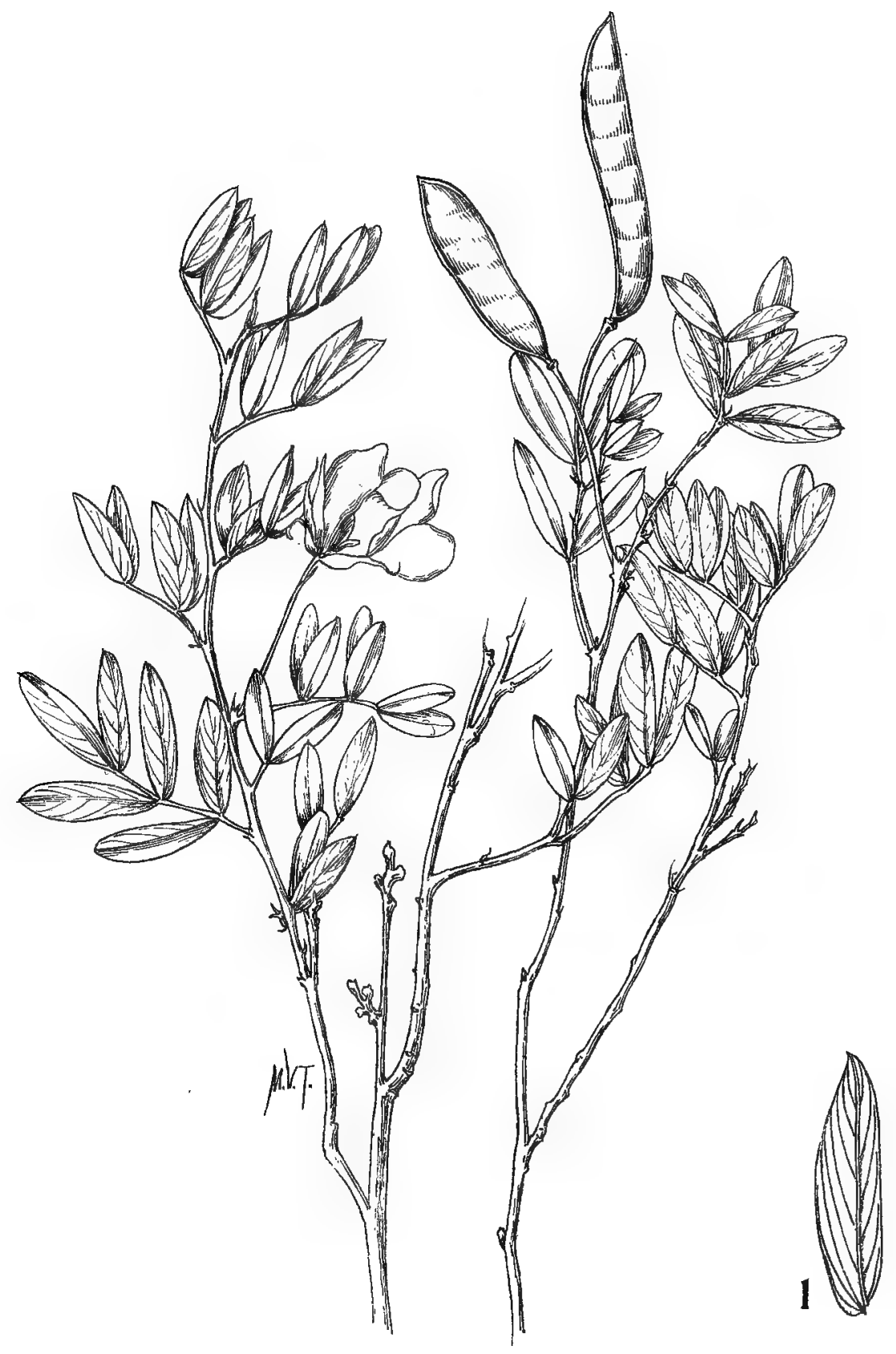

CASSIA CARIBAEA 

Tamarindus Indica L. "Tamarind." Fresh Creek, June; Deep Creek, July $(642,7$ I 7$)$.

Hamatoxylon Campechianum L. "Logwood." Nassau, Jan.; Lisbon Creek, Andros. Naturalized (I95).

Cesalpinia ovalifolia Urban. "Nicker-bean." Nassau, Jan. (I 6). Described in Symbolæ Antillanæ, 2273. O. I900.

Casalpinia CRISTA L. (C. Bonducella L.) "Nicker-tree." Nassau, Jan. (I06). Both species quite common on New Providence and Andros on sandy beaches.

Casalpinia Rugeliana Urban. Common in the pines. Conch Sound, March (426). Same as Wright 2364.

Peltophorum adnatum Griseb. "Horse-bush." Upper surface of leaflets hirsute. Otherwise same as Wright 2359. Deep Creek, July (7 12$)$.

Poinctana Regia Boj. "Poinciana," "flamboyant." Cultivated at Nassau, Mastic Point and Deep Creek, Andros (59I).

C ÆSALPINIA PUlcherRima Sw. "Pride of Barbadoes." Cultivated at Nassau and Mastic Point (Io).

\section{Papilionace es}

Sophora tomentosa L. Conch Sound, March; Deep Creek, July (4II, 727). Same as Eggers 2573, but is not nearly as tomentose.

Crotalaria pumila Ort. Nassau, Jan. (67). Same as Curtiss 533.

Crotalaria retusa L. Nassau, Jan. 22I. Same as Wright ir7.

Crotalaria verrucosa L. Nassau, Jan. (54).

Indigofera ANIL L. Nassau, Jan. (I75).

Cracca Schottir Vail. In old field, Lisbon Creek, Andros, June (678). Agrees with specimens from Cartagena, Schott, No. r6. Determined by Miss Anna Murray Vail.

Stylosanthes hamata (L.) Taub. (S. procumbens Sw.) Nassau, Jan. (37).

Meibomia incana (Sw.) Kuntze. (Desmodium incanum (Sw.) DC.) Nassau, Jan. Common (224).

Abrus PRECATORIUS L. "Crab's eyes," "Black-eyed-Susan," "Wild licorice." Nassau, Jan. (239).

Bradburya Virginiana (L.) Kuntze. (Centrosema.) Very com- 


\section{FLORA OF NEW PROVIDENCE AND ANDROS}

mon, fruit and leaves variable. Nassau, Jan.; Fresh Creek, June $(82,227,629)$.

Bradburya Virginiana angustifolia (DC.) Griseb. Fresh Creek, June (756).

Galactia rudolphioides (Griseb.) Wright. Common. Nassau, Jan.; Nicol's Town, March, April (214, 219, 395). Agrees with Wright II8I.

Galactia Cubensis H. B. K. (G. spiciformis T. \& G.) Nassau, Jan.; Fresh Creek, June (60, 226, 648). Agrees with Wright 2332.

Canavalia obtusifolia (Lam.) DC. "Horse-bean." Common on sandy beaches. Nassau, Jan.; Conch Sound, April (II 2, 452). Legume $2.5 \mathrm{~cm}$. wide. Same as Curtiss 682, and Eggers 2724, unnamed specifically.

Dolrcholus minimus (L.) Medic. Nassau, Jan. (2I5). Same as Curtiss 656 .

Phaseolus semierectus L. Common. Southwest Beach, N.P., Jan.; Mangrove Cay, Andros, June (329). Same as Wright I37.

Vigna RePens (L.) Kuntze. Nicol's Town, March (386). Same as J. Donnell Smith $\mathrm{r} 8 \mathrm{I}, \mathrm{Pl}$. Guat.

Cajanus Cajan (L.) Millsp. "Pigeon-pea." Cultivated and escaped on both islands. Nassau, Jan. (98).

Dalbergia Brownei (Pers.) Kuntze. "Ti-ti." Kemp Sound, Andros, June (680).

Ichthyomethia Piscrpula (L.) A. S. Hitchc. (Piscidia Erythrina L.) Conch Sound, May (588). Same as Curtiss 685.

ARACHIS HYPOGAA L. "Groundnut." Cultivated. Mastic Point, May (600).

Erythrina Corallodendron L. "Lightning tree." Cultivated. Nassau (308).

\section{OXALIDACE}

Oxalis corniculata repens Zucc. Nassau, Feb. (330).

OxaLIs sp. Acaulescent, bulbs scaly; leaflets broadly obcordate, about $5 \mathrm{~cm}$. wide and $2 \mathrm{~cm}$. long; petioles $\mathrm{I} 4-\mathrm{r} 6 \mathrm{~cm}$., a little longer than the scape: flowers pale purple, about $\mathrm{I} \mathrm{cm}$. wide. Near O. latifolia Kunth. Nassau, Feb. Probably escaped (33I). 



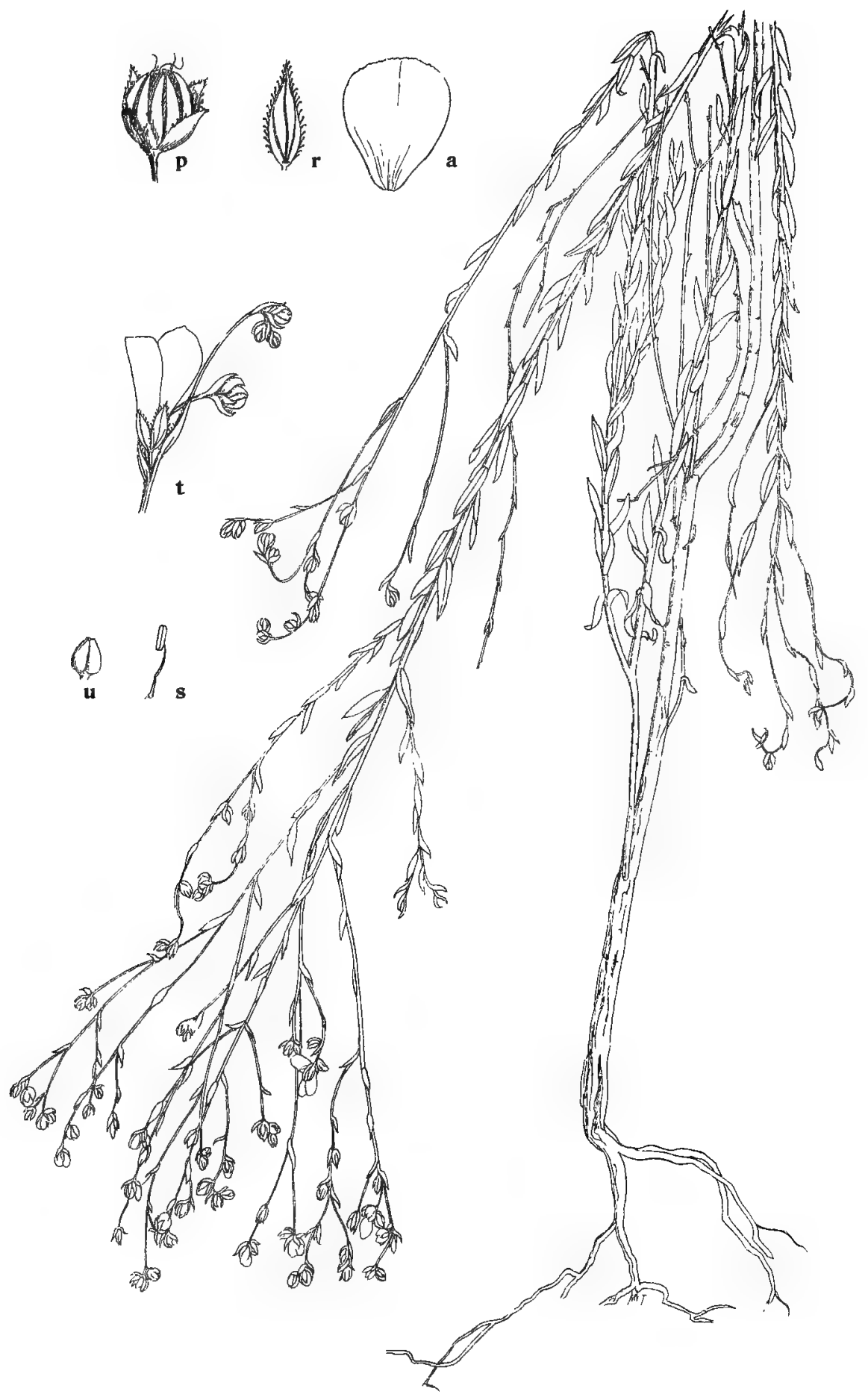

LINUM BAIIAMENSE 


\section{LINACE $\mathbb{E}$}

Linum Bahamense sp. nov.

Suffruticose, 3-6 dm. in height, corymbosely branched, branches erect-ascending; stems sulcate; leaves numerous, alternate, sessile, appressed-ascending, whitish, linear-lanceolate, 8-I I mm. long, a little more than I $\mathrm{mm}$. wide, one-nerved, the midrib prominent on the under side and projecting at the apex so as to form a mucro, margin entire or the younger leaves glandular-ciliate, glabrous or with a few scattered hairs at the base or along the midrib on the upper side; two dark stipular glands at the base of the leaves; flowers corymbose, numerous; pedicels short, $2 \mathrm{~mm}$. in length, bracts ciliate-glandular; sepals 5, lanceolate, acuminate, $2-3 \mathrm{~mm}$. long, ciliate-glandular, keeled, persistent; petals bright yellow, more than twice the length of the sepals, obovate; stamens 5 , united at the base included.; anthers oblong; styles 5, distinct, filiform; ovary globose, imperfectly ıo-celled, ovules ro, capsule globose, $2-3.5 \mathrm{~mm}$. in diameter, about as long as the calyx, splitting into to valves; seeds oblong, compressed, reddish-brown (204, 496).

Common in the pines on both islands. Collected at Lake Waterloo near Nassau, Jan. 25; near Southwest Beach, N.P., Feb. 26; at Red Bays on the west side of Andros, April I7; also collected in N.P. by Eggers, No. 4I8I.

This is related to $L$. sulcatum Riddell, but the styles are distinct, the leaves are one-nerved and the septa of the capsule are not glandular.

Plate 7. Linum Bahamense. Entire plant, $\times \frac{6}{7} ; t$, flowers and buds; $r$, sepal; $a$, petal; $s$, stamen; $u$, anther; $p$, fruit.

ERYTHROXYLON BREVIPES DC. "Rat-wood." Deep Creek, June (692). Same as Wright 2I34 and Eggers 2435 unnamed specifically.

Erythroxylon obovatum Macf. Mastic Point, May (597). Same as Eggers 4345 from Bahama; leaves thicker and veining more conspicuous than in Wright 2140 from Cuba.

\section{Erythroxylon reticulatum sp. nov.}

Tall shrub with slender branches; reddish brown verrucose bark, branchlets strongly compressed; leaves oblanceolate or oblong, $2.5-3 \mathrm{~cm}$. long, half as wide, broadly obtuse and mucronulate at the apex, narrowed below to a short petiole, $2-3 \mathrm{~mm}$. 


\section{FLORA OF NEW PROVIDENCE AND ANDROS}

long, glabrous, thickish, entire, dull green above, pale below, areolate, the reddish connecting veins circumscribing a central area 4-6 mm. wide; midrib reddish, prominent, veins delicate, prominulous above; stipules persistent, triangular, acuminate, shorter than the petioles, reddish brown; flowers axillary, appearing with the leaves, solitary or sometimes in pairs; pedicels $5-8 \mathrm{~mm}$. long, slender below, gradually thickening and wing-angled above; calyx spreading, sepals 5, lanceolate, about one-third the length of the petals; petals white, $3-3.5 \mathrm{~mm}$. in length, deciduous, elliptical-oblong, slightly keeled on the back, internal scale 2-lobed and contorted at the apex; stamens Io, 4-5 mm. long, exserted, filaments united over one-third of the way, tube extending a little beyond the sepals; ovary oblong, 3-celled; styles 3 , distinct; stigmas flattened, reddish; young drupe oblong, pointed, purplish black, 5 mm. in length.

Collected at Deep Creek, Andros, June 27 ; growing in sand (682). Most nearly related to E. areolatum L.

PLATE 8. Erythroxylon reticulatum. Portion of plant, $\times \frac{6}{7} ; a$, flowering branch; $d$, flower without corolla; $n$, petal.

\section{MALPIGHIACE 仺}

Byrsonima IUCIDA Rich. Common on Andros on the edge of the coppet. Our specimens resemble those from Florida more closely than they do the West Indian specimens; the latter all have broader, and obovate, instead of oblanceolate or spatulate leaves. Nicol's Town, March (367). Same as Curtiss 50r. Largest specimen seen one foot in diameter and about twenty feet in height.

Malpighia setosa Spr. "Touch-me-not." Fresh Creek, June (737). Determined by Dr. Britton at Kew to be "the same as a specimen marked $M$. setosa by Jussieu; collected also by Brace No. II4."

A number of specimens were collected at various times which seem to vary greatly; possibly more than one species is represented. No. 737 was collected in the pines at Fresh Creek. It was a tall shrub with whitish bark, oblong leaves, $2-3.5 \mathrm{~cm}$. long, I $2-20 \mathrm{~mm}$. wide, entire or nearly'so, hairs few on margin and under surface; inflorescence, two-flowered umbels; pedicels $8-\mathrm{I} 3 \mathrm{~mm}$.; flowers rosy, I2-I5 mm. wide; drupe globose, furrowed. 

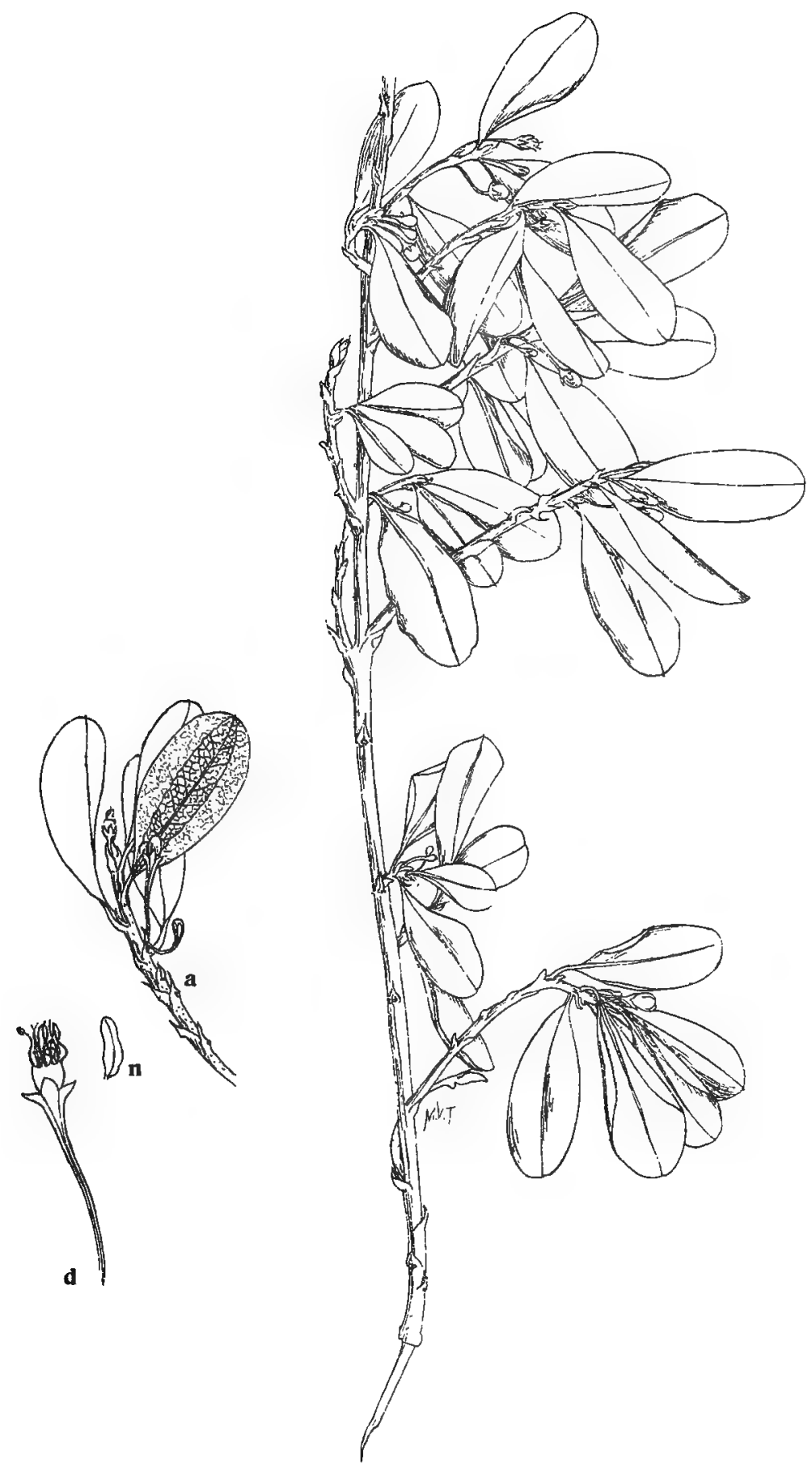

ERYTHROXYLON RETIENLATUM 

No. 538 was a single specimen from the pines at Stafford Creek, collected in May, differing from the above in having the leaves thicker but only half as wide, $2-3 \mathrm{~cm}$. long and 8-ro $\mathrm{mm}$. broad, pointed at base and apex, margin dentate or strongly denticulate. No. $538 a$ is a specimen in fruit, collected at Conch Sound, leaves broader than in above, denticulate and with hairs on both sides of the leaf; $538 b$, also from Conch Sound, sent by Mr. Keith, has oval or ovate leaves $2-2.5 \mathrm{~cm}$. wide, with strongly dentate margins, hairs beneath and on the margin, flowers smaller than in 737. All the above specimens differ very much from $\mathrm{Wr}$. No. 99, marked $M$. setosa, which is in leaf only; that has leaves less than half the size of any of ours, hairy above and strongly hirsute beneath.

Stigmatophylion Sagrenum Juss. Not uncommon in the pines. Conch Sound, March; Red Bays, April (40I-468). Same as Rugel I57.

TrIOPTERIS RIGIDA Sw. Common in the coppet. Nassau, Feb.; Conch Sound, May; Calabash Cay, Andros, June (2I7). Same as Wright $96 . \quad 217 a$ from Deep Creek has the leaves oblanceolate or obovate, I2-I $7 \mathrm{~mm}$. wide; all the other specimens collected have oblong or elliptical leaves 7 -1o mm. wide.

\section{RUTACAE}

Fagara Flava (Vahl) Krug \& Urban. (Xanthoxylon cribrosum Spreng.) "Satin-wood." Deep Creek, June (695).

FAgara CORIACEA (A. Rich) Krug \& Urban. (Xanthoxylon emarginatum Wright.) "Hercules' club." Common in the coppet. Nicol's Town, March; Mastic Point, April; Deep Creek, June (372). Same as Eggers 4034, 4503, Brace 5Io. Carpels globose, not oblique.

Fagara Fagara (L.) Small. (Fagara lentiscifolia Willd.) Nassau, Nicol's Town (747).

\section{SIMARUBEA}

SURIANA maritima L. "Bay-cedar." Common along the shore on both islands. New Providence, Jan. (86). Same as Eggers 2728 .

Picrodendron baccatum Bahamense Krug \& Urban. Conch 
Sound, April (453). Determined at Kew by Dr. Britton. Same as Eggers 4402 , Brace 476 .

\section{BURSERACE E}

Bursera Simaruba (L.) Sarg. "Gum elemi," "West Indian birch." Common on both islands. Nassau, Jan.; Conch Sound, May $(64,560)$.

Swietenia Mahogani L. "Madeira." Nassau, Jan.; Mangrove Cay, June $(\mathrm{I} 37,676)$. Same as Eggers 1836 , Wright II 53 .

\section{Polygalace}

Polygala Boykinir Nutt. Common on savannas on west side of Andros. Red Bays, April (473).

Polygala BRIzomes St. Hil. Common in savannas on west side of Andros. Red Bays, April (465). Determined at Kew by Mr. A. W. Bennett - "sed racemi quandoque axillares."

Polygala Spathulata Griseb. Conch Sound, March (402). Determined by Mr. A. W. Bennett at Kew.

\section{EUPHORBIACE}

Buxus BaHamensis Baker. On savanna. Near the shore at Red Bays, April (460). Determined by Dr. B. L. Robinson at Gray herbarium.

Phyllanthus Epiphyllanthus L. ( $P$. falcatus Sw.) "Hardhead." Common on both islands. Nassau, Feb.; Nicol's Town, March (I46-325). Same as Eggers 7234. Branchlets narrower than in Wright r95I. No. I46a and $146 b$ have branchlets very narrow, 8-ro $\mathrm{cm}$. long and 6-8 $\mathrm{mm}$. wide, apex more acute, pedicels longer and more slender, $3 \mathrm{~mm}$. in length.

Phyllanthus Distichus L. "Gooseberry tree." Fresh Creek, June, escaped (653).

Phyllanthus Niruri L. Nicol's Town, March (338).

Phyllanthus Bahamensis Urb. Lewis Coppet near Red Bays, Andros, May (488). Same as Eggers 424r, 4464.

Savia ERYTHROXYLoIdes Griseb. "Maiden-bush." Not unfrequent in the coppet. Fresh Creek, Deep Creek, June. In fruit only (6ro). Determined by Mr. M. L. Fernald.

Croton linearis Jacq. (C. Cascarilla linearis Jacq.) "Granny- 
bush." Common along the eastern shores of both islands. Nassau, Jan.; Fresh Creek, June (II3, 6I5).

ManiHot ManrHot (L.) Cockerell. (Jatropha Manihot L.) "Sweet cassava." Cultivated and escaped. Nicol's Town, March (363).

Acalypha alopecuroides Jacq. Nassau, Jan. (32). Same as Wright $57 \mathrm{I}$.

LASIOCROTON MACROPHYLLUS Griseb. "Wild oak," "Lightwood," "Bitters." Deep Creek, June (689). Agrees with specimen of March from Jamaica except that the upper surface of the leaves is smooth instead of velvety, and the apex is obtuse instead of acute.

ExcCeCARIA LUCIDA Sw. "Crab-wood." Nicol's Town, March; Fresh Creek, June (375).

Exccecaria SAgreI J. Müll. Stafford Creek, Andros, May (589). Same as Wright 2006.

Hippomane Mancinella L. "Manchineel." Not uncommon on Andros. Conch Sound, May; Fresh Creek, June (556, 622). In 662 the sap did not seem at all milky. All the herbarium specimens examined showed the leaf apex acute or acuminate, while all of ours have the apex very blunt.

Bonania emarginata DC. Fresh Creek, June (628).

Pedilanthus sp.? possibly $P$ - angustifolius Poit.

Shrubby, 7-9 $\mathrm{cm}$. high, half scandent with green, rather fleshy stems, very little branched. All the plants seen were destitute of leaves though alternate leaf scars are discernible, 4-5 cm. apart, scars of !the floral leaves opposite; flowers in terminal cymes, peduncles $4-5 \mathrm{~cm}$. in length; involucre bright red, pubescent, about $8 \mathrm{~mm}$. long, irregular, with a sharp spur at the side, $5 \mathrm{~mm}$. long; spurred part of involucre with four glands at base: staminate flowers indefinite: pistillate ones exserted: style ro $\mathrm{mm}$. in length.

Collected in two localities in the coppet at Deep Creek, June (693).

Resembles $P$. angustifolius Poit. as shown by $769 \mathrm{Pl}$. Sintensis in Gray herbarium, but specimen not in good flower.

EupHORBIA Blodgettil Engelm. Nassau, Jan.; Nicol's Town, March (4I, 379).

EUPHORBIA BUXIFOLIA Lam. Common on sandy beaches. 


\section{FLORA OF NEW PROVIDENCE AND ANDROS}

Southwest Beach, N.P., Jan.; Red Bays, April $(87,457)$. No. 672, a form with leaves not appressed, was collected at Big Cabbage Creek on the west side of Andros in June. Same as Wright 2016. EupHoRbIa CASSYTHoIdes Boiss. Rare, Deep Creek, June (702). Determined at Kew, I897.

Euphorbia heterophylla L. Common in the pines. New Providence, Jan. (96).

EUPHORBIA HETEROPHYLLA GRAMINIFOLIA Engelm. Same locality (92).

Euphorbia nutans Lag. Common. Nassau, Jan.; Nicol's Town, March (229, 380). Our specimens agree with Professor Hitchcock's in having the upper internodes slender, especially in 229, and no dark spots on the leaves. (See Hitchcock's Report, Plants of the Bahamas, Jamaica and Grand Cayman.)

EupHORBIA SERPENS Kunth. Nassau, Jan. (277). Same as specimen of Rugel, No. I48 marked E. serpens var.? Much branched, delicate, with slender wiry stems, enlarged nodes, leaves $3-4 \mathrm{~mm}$. in length.

Euphorbia pulcherrima (Graham) Boiss. "Poinsettia." Nassau, common in cultivation.

EUPHORBIA ANTIQUORUM L. Nassau, cultivated.

HURA CREPITANS L. "Sand-box tree." Nassau, cultivated.

\section{ANACARDIACE}

Metopium Metopium (L.) Small. "Poison-wood." Common in the coppet on both islands. Nassau, Jan.; Conch Sound, May (70, 552). 'Same as Wright 2287, Curtiss 448.

\section{MORINGACE $\mathbb{E}$}

Moringa Moringa (L.) Small. "Horse-radish tree." Nassau, cultivated (3I0).

\section{Celastrace A}

ElaOdENDRUM XYLOCARPUM DC. Nassau, Jan. (7I). In fruit only. Determined by Mr. M. L. Fernald, Cambridge.

Maytenus buxifolius (Rich.) Griseb. Fresh Creek, June. Differs from Wright 2215 and all other specimens examined in having 


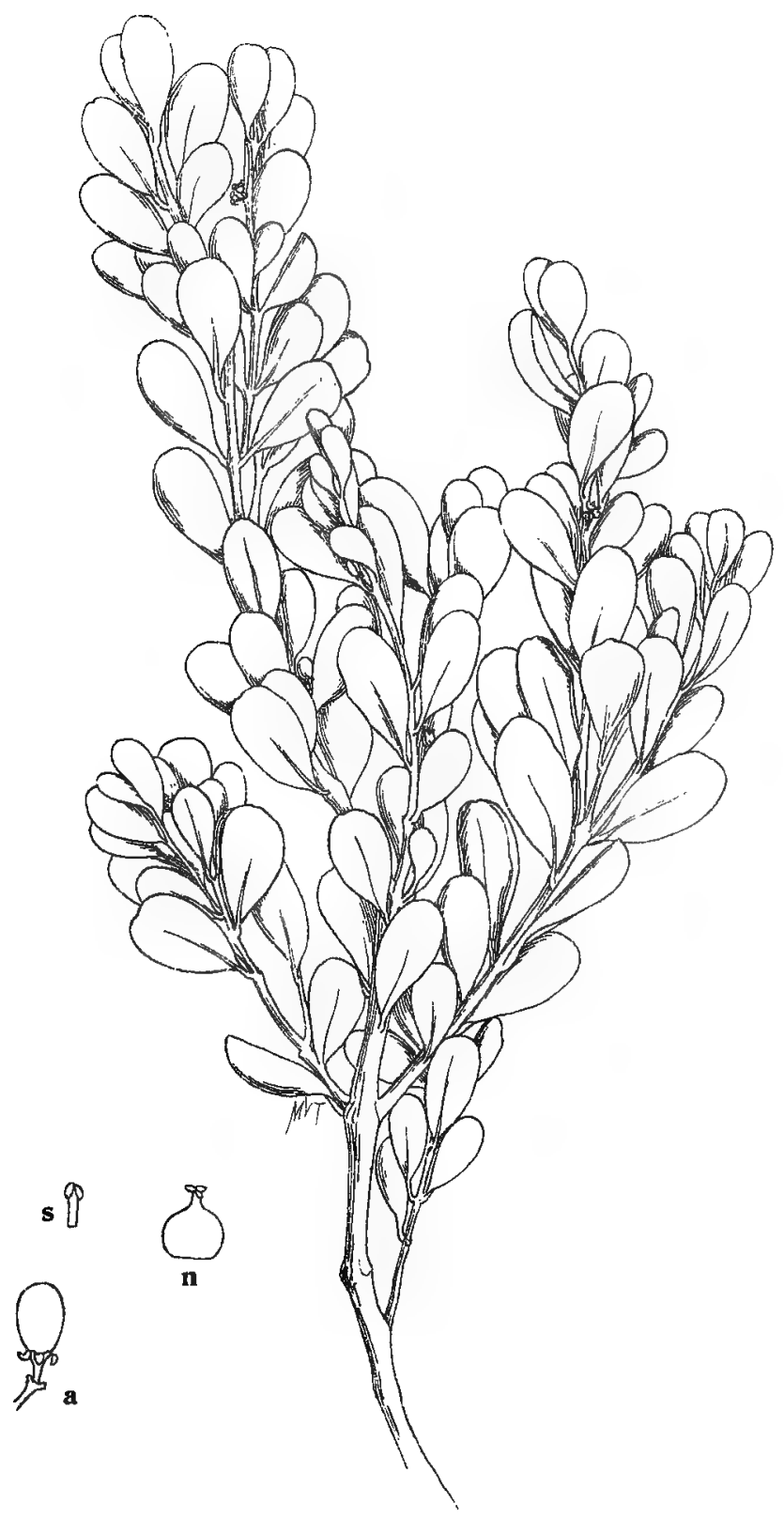



the leaves narrower and more spatulate, $2-2.5 \mathrm{~cm}$. long, 6-9 mm. wide (626).

Crossopetalum pallens (Smith). (Myginda pallens Smith.) Cocoanut Point, April; Deep Creek, June (447, 718). Like Eggers 4I4O and 4438 from New Providence, "put with $M$. pallens at Kew." Differs from the Florida specimens in having much narrower leaves, oblanceolate or spatulate, $2-2.5 \mathrm{~cm}$. long, 4-9 mm. wide.

\section{Crossopetalum coriaceum sp. nov.}

Low shrub; branches ascending, bark grayish, branchlets tetragonal, ends somewhat wing-angled; leaves numerous, opposite, subsessile, coriaceous, broadly oblanceolate, $1.5^{-2} \mathrm{~cm}$. long, about I $\mathrm{cm}$. wide, apex obtuse or sometimes slightly retuse, base cuneate, margin entire, somewhat revolute, veins inconspicuous; flowers minute, reddish, in axillary subsessile cymes, 2-5-flowered, pedicels I-2 mm. in length, jointed, pedicels and calyx puberulous; calyx campanulate, persistent, lobes 4, rounded, reddish, obtuse; petals 4, orbicular, longer than the calyx, spreading or at length reflexed; stamens 4 , inserted on the edge of the disk; filaments subulate; anthers small, globose; ovary immersed in the disk, globose: style short: stigmas 4: fruit a red drupe, slightly obovate, about $3 \mathrm{~mm}$. in length, one-celled, one-seeded (480). $a$, fruit.

PLATE 9. Crossopetalum coriaceum. Portion of plant $\times \frac{5}{6} ; s$, stamens; $n$, ovary;

Collected on the savannas at Red Bays. Andros, April. Allied to $C$. pallens (Smith), but differs in having thicker entire leaves and smaller subsessile cymes.

Scherfferia Frutescens Jacq. Deep Creek, June (697). Same as Wright 77 .

\section{ILICACE $\mathbb{E}$}

Ilex Krugiana Loes.; Engler's, Bot. Jahrb. I5, 3I7. Conch Sound, May. Upper surface of the leaves shining, apex acute (553). Same as Cooper I7 from New Providence, and Eggers r889 from St. Domingo (unnamed).

\section{SAPINDACE}

Serjania diversifolia Radlk. "Fowl-foot vine." .Common. Conch Sound, May; Fresh Creek, Deep Creek, June (578, 687). Same as Wright rog. 


\section{FLORA OF NEW PROVIDENCE AND ANDROS}

Serjania subdentata Juss. \& Poir. "Fowl-foot vine." Common in the coppet. New Providence, Jan.; Fresh Creek, June (236). Same as Wright $2 \mathrm{I} 62$.

Cardiospermum Halicacabum L. "Balloon vine." Nassau, Jan. (237).

ThouInIA DISCOLOR Griseb. "Quicksilver bush." Nicol's Town, March; Conch Sound, May; Deep Creek, June (368,59o, 686).

Exothea paniculata (Juss.) Radlk. Nicol's Town, March (392). Same as Wright $1 \pm 69$.

Hypelate trifoliata Sw. "Ebony." Deep Creek, June (69o). Same as Wright 2I 7 I.

Alvaradoa Amorphioides Liebm. Nassau, Jan. (145). Same as Wright 2I89.

\section{RHAMNACE $\mathbb{E}$}

Krugtodendron ferreum (Vahl) Urban. (Condalia.) Fresh Creek, June (6II).

Reynosia NoRTHRopiana Urban, Symbolæ Antillanæ 3: 3I5. I9O2.

Plate Io. Reynosia Northropiana. Portion of plant $\times \frac{4}{3}$; $e$, flower; $m$, interior of calyx showing stamens and petals; $a$, stamen and petal; $n$, petal; $d$, pistil.

Red Bays on the west side of Andros, April 23, and at Nicol's Town on the east side, April 28 (5 I0).

Reynosia latifolia Griseb. Common on border of swash on west side of Andros. Purser Point, June (66r).

Colubrina Ferruginosa Brongn. "Bitters." Deep Creek, June (684). Same as Wright II39.

Godania Domingensis L. "Chew-stick." Common on both islands. Nassau, Jan. (69).

\section{VITACE}

Vitis rotundifolia Michx. Common. Conch Sound, May (559).

Cissus microcarpa Vahl. "Bull-vine." Common in the southern part of Andros. Deep Creek, June (694). Same as Wright 72.

Cissus sicyoides L. Conch Sound, May (582). Same as Wright 74.

CIssus, sp. "Bull-vine." Quite common in the northern part 


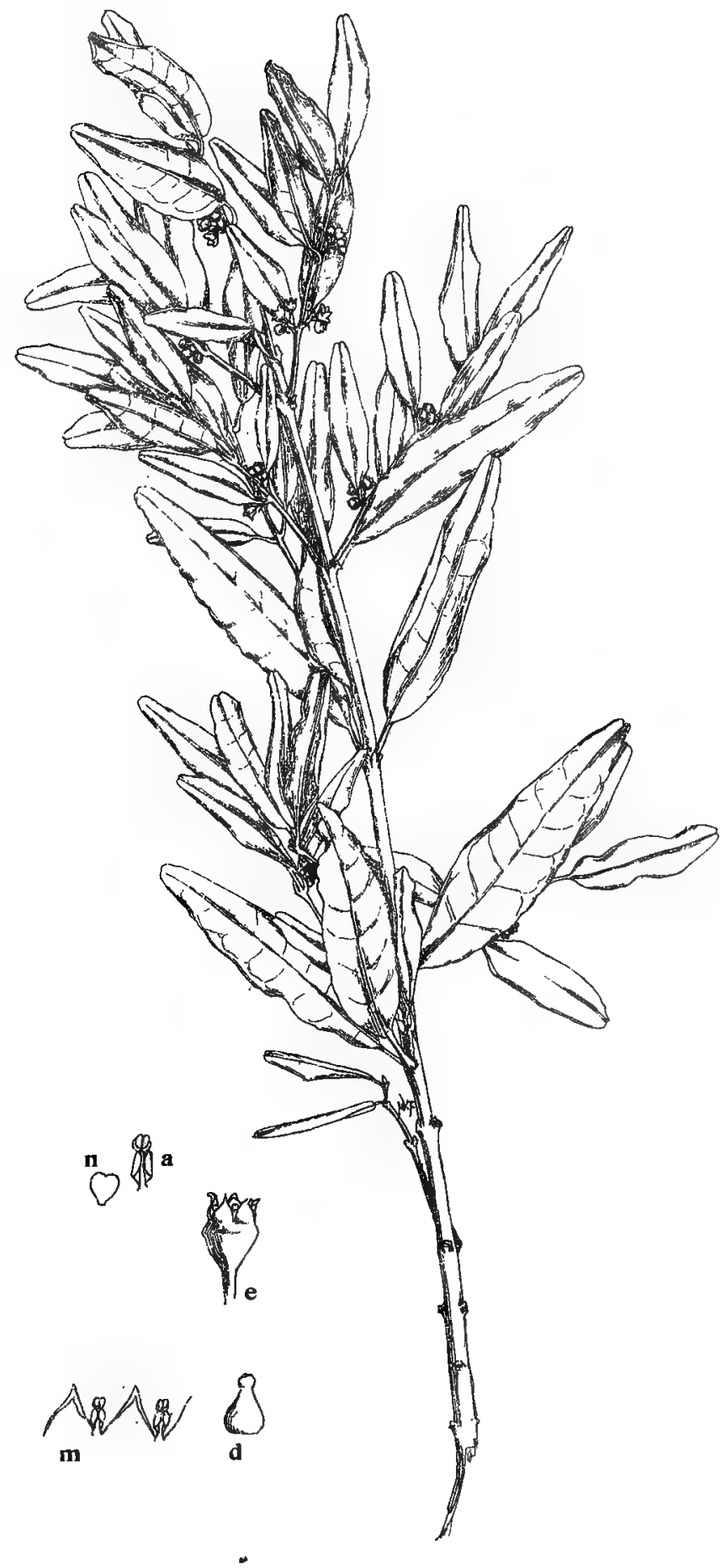

REYNOSIA NORTHROPIANA URBAN 



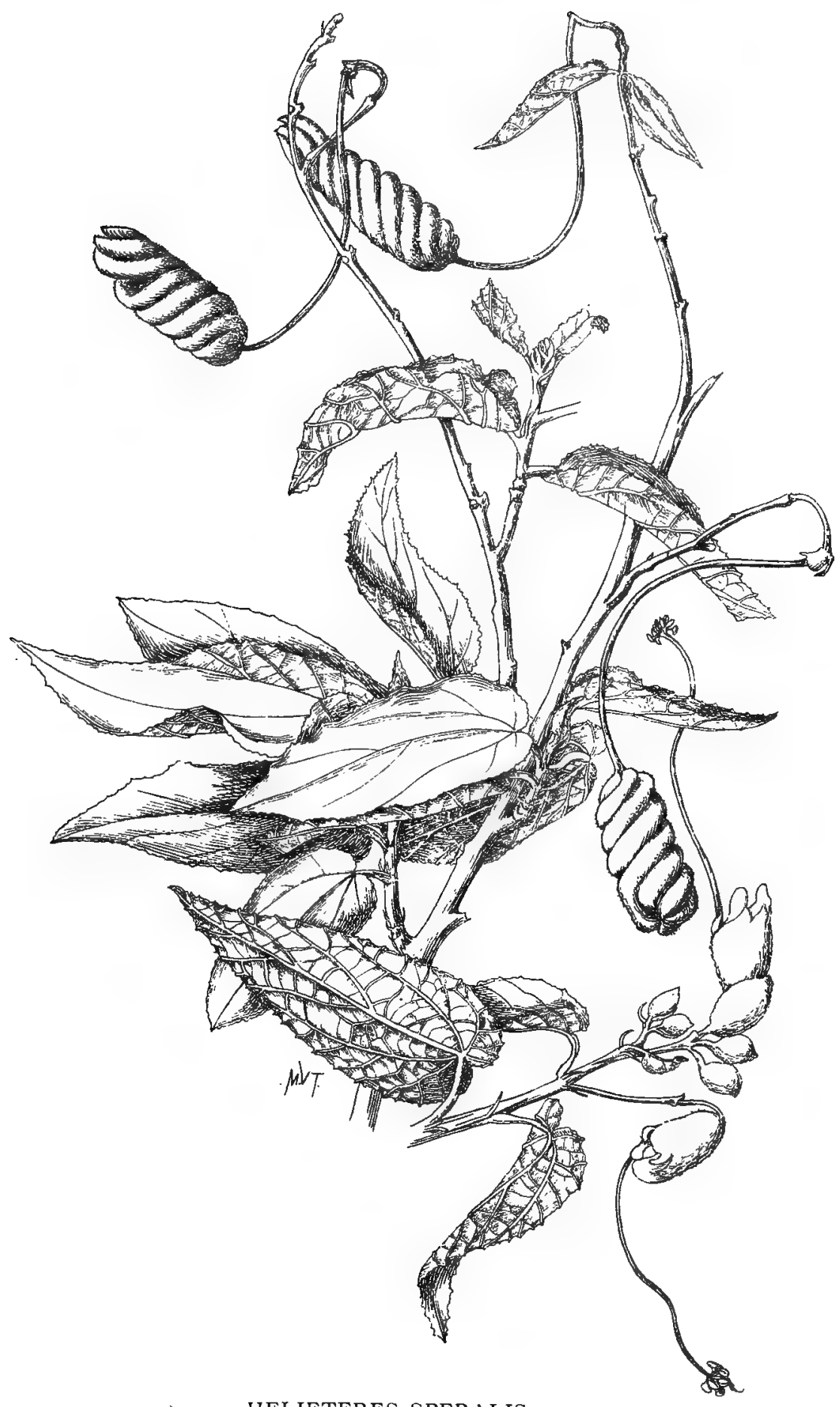

HELIETERES SPERALIS 

of Andros. Conch Sound, March, May (398). Same as Wright 35 I4.

Parthenocissus Quinquefolia (L.) Planch. (Ampelopsis quinquefolia (L.) Michx.) Carmichael, New Providence, Feb. (322). Single specimen.

\section{TILIACE}

Triumfetta semitriloba L. Common about Nassau. Jan. $(4,47)$.

Corchorus hirsutus L. Common on both islands. Nassau, Jan.; Nicol's Town, March (202). Same as Wright 2091.

Corchorus siliquosus L. Common about Nassau; very variable in the size of the leaves. Nassau, Jan. (I39, 222).

\section{Malvace}

Sida CARPinifolia L. Common. Nassau, Jan. (35). A very strict form with crenate leaves found at Nicol's Town, April (433).

Sida supina L'Her. Nassau, Feb. (306).

Abutilon CRISPUm (L.) Medic. Nicol's Town, March (370).

Pavonia spicata Cav. (P. racemosa Sw.) Collected by $\mathrm{Mr}$. Alexander Keith at Conch Sound, I89I (736).

Hibiscus CRYptocarpus Rich. "Wild cotton." Nicol's Town, March; Deep Creek, June (397). Same as Wright 'I575.

Hibiscus Esculentus L. "Gumbo," "okra." Conch Sound, May. Cultivated and escaped (549).

Hibiscus tiliaceus L. Not uncommon along the east coast of Andros. Conch Sound, May (564). Same as Eggers 2632.

CEIBA PENTANDRA (L.) Gaertn. (Eriodendron anfractuosum DC.) "Silk-cotton tree," "Ceiba." Nassau, cultivated and escaped? Nassau, Jan. ( $\left.{ }_{5} 5^{2}\right)$.

\section{STERCULIACE}

Helicteres semitriloba Bertero. Fresh Creek, June (664).

Helicteres spiralis sp. nov.

A tall shrub; young branches and leaves tawny tomentose; leaves lance-ovate, acute, unequal and cordate at base, $6-9.5 \mathrm{~cm}$. long, $2.5-4 \mathrm{~cm}$. wide, 3-5-ribbed, margin crenulate-denticulate, sometimes with a few large teeth, upper surface pubescent, under 


\section{FLORA OF NEW PROVIDENCE AND ANDROS}

tomentose, hairs tawny, stellate; petiole about I cm. in length; stipules subulate; inflorescence fascicled, few-flowered, peduncles I. 5-2 cm. long, pedicels glandular at base; calyx campanulate,

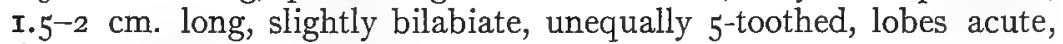
densely tomentose, about one-fourth the length of the column; petals 5, white, shortly exceeding the calyx, oblong, clawed, subequal, the lower auricled near the base; column $7-8 \mathrm{~cm}$. in length, declined, covered with long mostly simple hairs; stamens to, arranged in pairs, anthers divergent-oblong, staminodia 5, ligulate; ovary tomentose, 5-celled; styles united, thickened at the apex; pod twisted, oblong, about $4.5 \mathrm{~cm}$. in length; convolutions about IO, tomentose or at length glabrous.

Collected near the mouth of Fresh Creek, Andros, June; also collected at Conch Sound by Mr. Alexander Keith, I89r (645).

Plate I I. Helicteres spiralis. Portions of plant in flower and fruit $\times \frac{1}{2}$ nearly.

Melochia nodiflora Sw. Nassau, Jan. (45). Same as Wright 39 .

Melochia tomentosa L. Common on both islands. Nassau, Jan.; Nicol's Town, March (253). Same as Wright 40; same as Eggers I99I.

Waltheria Americana L. Common on both islands; very variable. Nassau, Jan.; Nicol's Town, March (89, 230, 429).

W. Americana var.? ( ${ }_{3} 6,207$ ). Collected at two different stations in Nassau, differing from all specimens examined in having leaves smaller, $\mathrm{I}^{-} 2 \mathrm{~cm}$. long, $7-\mathrm{I}_{3} \mathrm{~mm}$. wide, marginal teeth not as acute, and in having both leaves and stems covered with stellate hairs; plant tall, less stout than the type.

\section{HYPERICACE $\not E$}

ASCYRUM HYPERICOIDES L. Common in the pines on both islands. Nassau, Jan.; Conch Sound, May (323). Same as Wright 2I 29 and Eggers 2047 (unnamed).

\section{BrXACE $Æ$}

\section{Xylosma ilicifolia sp. nov.}

Shrub 2-3 $\mathrm{m}$. in height, bark grayish, verrucose, usually armed with slender spines $\mathrm{I}-4 \mathrm{~cm}$. long, spines often much branched; leaves alternate, variable in shape, oval, oblanceolate or obovate, $2-3 \mathrm{~cm}$. in length, I-2 $\mathrm{cm}$. wide, coriaceous, shining above, apex acute and 


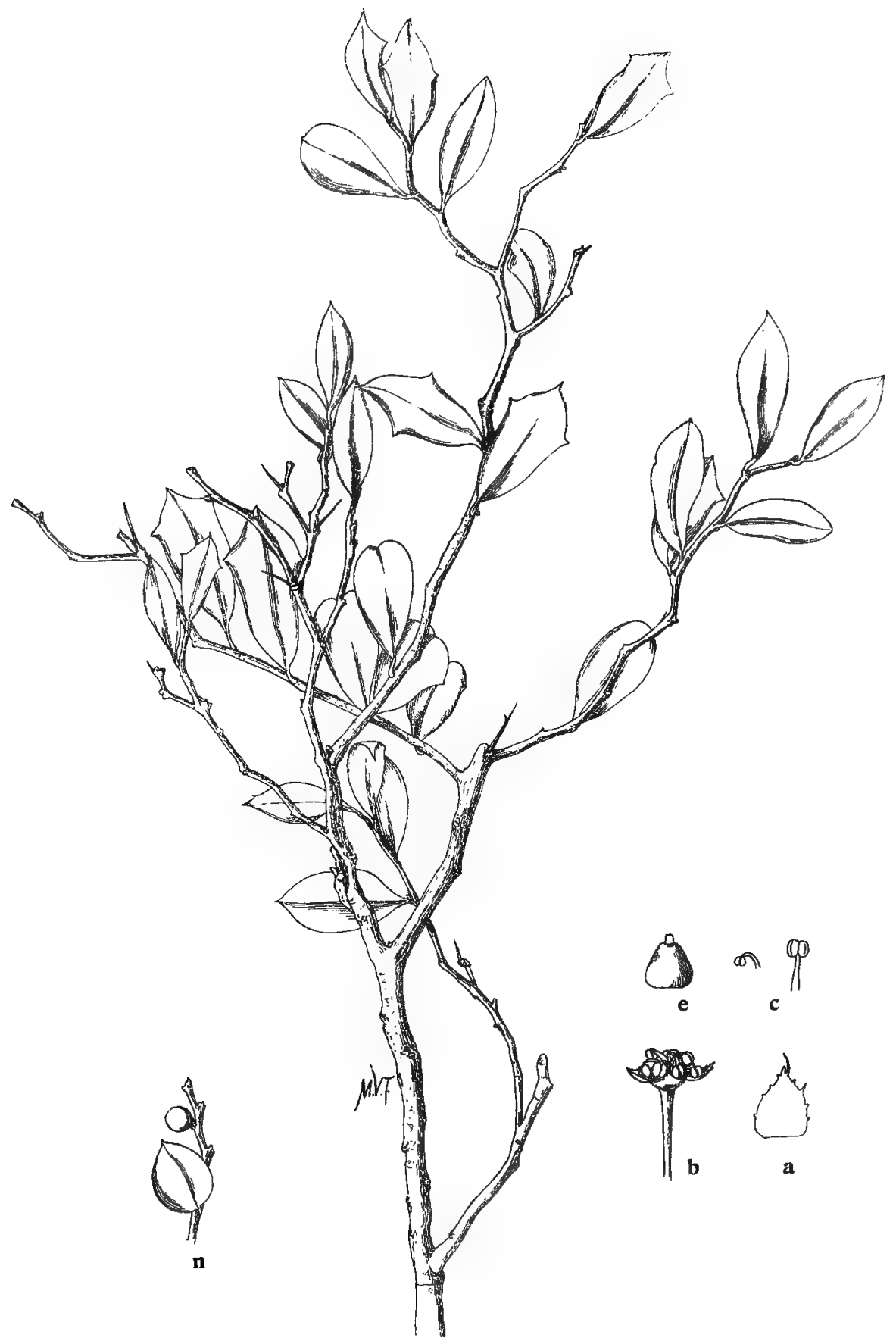

XYLOSMA ILICIPOLIA 

strongly mucronate (or sometimes obtuse), margin entire or frequently with one to three large, mucronate teeth on the upper half of the leaf, base cuneate or sometimes obtuse, petiole I-2 $\mathrm{mm}$. in length; flowers diocious, minute; staminate greenish, in axillary fascicles of $5^{-6}$, very short-pediceled, bracts minute, ciliate; sepals $4-5$, ovate, ciliate at apex; stamens 8-ro, filaments recurved, longer than the anthers, anthers globose, disk annular; pistillate flowers $2-3$ in a cluster, pedicels about I mm. in length; sepals 4 , lanceolate, ciliate towards the apex, pistil more than twice the length of the sepals, about I mm. long, ovary globose, styles two, thick, short, stigmas two, disk annular, berry globose, bluish black, about $5 \mathrm{~mm}$. in diameter, one-celled and four-seeded (I24, 388).

Collected at Nassau, Jan.; Nicol's Town, Andros, March 27 and April 9; Fresh Creek, June ro. It is the same as Cooper's I3 from New Providence, marked in pencil by Gray "Xylosma infestum?"; also collected by Governor Robinson 322; Brace 98 and Eggers 446. Seems to be between $X$. infestum Griseb. and X. buxifolium A. Gray; differs from the latter in having the upper surface of the leaves shining, apex mucronate, sepals ciliate, petioles and pedicels shorter, and in the shape and margin of the leaves.

Plate I2. Xylosma ilicifolia. Portion of plant, $\times \frac{a}{4} ; n$, fruit; $b b$, flower; $u$, sepal; $c$, stamens; $e$, ovary.

\section{Canellace $\mathbb{E}$}

Canella Winterana (L.) Gaertn. (C. alba Murray.) "Wild cinnamon," "Bahama whitewood bark." Not uncommon. Nassau, Jan.; Deep Creek, June (79, 708). Same as Wright 2122.

\section{TURNERACEA}

Turnera ulmifolia L. Common on both islands. Nassau, Jan. (57). Same as Wright 209 .

\section{PASSIFLORACEA}

Passiflora angustifolia Sw. Nicol's Town, Conch Sound, $\operatorname{March}(389,427)$.

PASSIFlora CUPReA L. "Wild watermelon." Common on both islands. Nassau, Salt Cay, Jan.; Nicol's Town, March (I2I, 243).

Passiflora minima L. Common. Nassau, Jan.; Salt Cay, Conch Sound, March (2I6, 242, 428). Same as Wright I245. 
Passiflora multiflora L. Nicol's Town, March (374). Determined at Kew by Dr. Masters.

Passiflora pectinata Griseb. Common on Andros in the pines. Nicol's Town, Conch Sound, March; Red Bays, April (39I).

Determined at Kew by Dr. Masters, who noted, "I do not like to separate this from $P$. pectinata, though it differs." The following constant characteristics were found in all the specimens collected. Leaves deeply contracted below the middle with marginal stipitate glands; petiole with a few stiputate glands towards apex; peduncles as long or longer than the leaves; leaflets of involucre bipinnatipartite, secondary segments long-setaceous; excurrent in a gland; calyx segments ovate-lanceolate; petals oblong; tendrils longer than the leaves.

\section{CARICACE}

Carica Papaya L. "Papaw." Deep Creek, July. Cultivated (I32).

\section{CACTACEA}

Cereus Swartzi Griseb. "Dildo.". On borders of creeks in the southern part of Andros. Deep Creek, June (699). $4 \mathrm{~mm}$. in height, $7.5^{-10} \mathrm{~cm}$. in diameter.

Opuntia spinosissima Mill. Along the shore. Fresh Creek, June $\left(6_{52}\right)$.

Opuntia Tuna (L.) Mill. Along the shore. Fresh Creek, June $\left(6_{33}\right)$.

\section{LXTHRACEA}

Parsonsia Parsonsia (L.) Britton. (Cuphea Parsonsia (L.) R. Br.) Near Southwest Beach, N.P., Feb. (318). Same as Eggers. I657.

\section{RHIZOPHORACE㞋}

Rhizophora MANGle L. "Mangrove." Common on both islands; the chief vegetation of the swash. Nassau, Jan. (r93).

\section{MYRTACE $Æ$}

Calyptranthes Pallens Griseb. "White stopper." Common in the coppet. Fresh Creek, Deep Creek, June (64I). 
Myrtus punctata Griseb. (Anamomis.) "Naked wood." Deep Creek, June (696).

Eugenia AXILlaris (Sw.) Willd. "Stopper." Deep Creek, June (707).

Eugenia longpies Berg. Red Bays, April; Conch Sound, May (47I). Same as Curtiss 985 from Florida.

Eugenia monticola DC. Deep Creek, July. In fruit only (725). Same as Curtiss 987 .

Eugenia sp.? Near E. longipes Berg.

A tree with smooth, white bark, branchlets slender, smooth; leaves thick, at length leathery, pale green, shining above with pellucid dots; oblanceolate or elliptical, obtuse, mostly cuneate at base, IO-I7 mm. long, 5-7 mm. wide, petioles I-2 mm., veining indistinct; flowers solitary or in pairs on long slender pedicels, $2-$ $2.5 \mathrm{~cm}$. long, bibracteolate, bractlets oblong, about equaling the calyx lobes. Flowers smaller than in E. longipes. In general appearance the tree resembles Myrtus punctata except that the leaves are smaller.

A single tree seen in the coppet at Deep Creek, July (722).

Psidium Guayava L. "Guava." Common in cultivation. Nasisau, Conch Sound (579).

\section{COMBRETACE}

Conocarpus EREcta L. "Button-wood." Abundant on both islands. Nassau, Jan.; Cocoanut Point, May (53, 298).

Conocarpus erecta sericea Fors. Nassau, Cocoanut Point (8I, 532). Same as Eggers 2608. At Cocoanut Point, both the glabrous type and the variety were growing together with no intermediate forms.

LaguñCularia Racemosa (L.) Gaertn. "Bastard button-wood." Common, especially in the swash. Fresh Creek, June (594).

Terminalia spinosa sp. nov. "Brier tree," "Prickly tree"

A low, spreading, flat-topped tree, height about 5 meters, I.5$2 \mathrm{dm}$. in diameter, bark lightish, ridged; branches horizontal, branchlets divaricate, spiny; leaves fascicled, subsessile, oblanceolate or spatulate, I-I.5 cm. long, 4-6 mm. wide, thick, glabrous, yellowish green below, obtuse or retuse at the apex, tapering into 


\section{FLORA OF NEW PROVIDENCE AND ANDROS}

a short petiole at base ( $\mathrm{I}-2 \mathrm{~mm}$.), margin entire, slightly revolute; spines axillary, slender, $3-7 \mathrm{~mm}$. in length, mostly in threes at the end of the branchlets; flowers small, greenish, growing in axillary spikes, the 5-7 flowers approximate, so as to resemble a head; peduncle 6-1o mm., bracts small, ovate; calyx valvate, tube $\mathrm{I}-2.5 \mathrm{~mm}$. long, prolonged beyond the ovary, constricted above it, limb campanulate, subtruncate, I-2 mm. long, with 5 small teeth, villous within, deciduous, disk of 4 brownish, villous, two-lobed glands at mouth of calyx tube; stamens 8 (9), exserted, about $3 \mathrm{~mm}$. in length, alternate ones inserted lower down on the calyx, filaments slender; anthers cordate; ovary I-celled; ovules 3 , flask-shaped or oblong, suspended from the top of the cell; style simple, equaling or slightly exceeding the stamens, subulate, a little thickened at base, villous; stigma simple, young fruit ovoid. Foliage closely resembling that of $T$. angustifolia but inflorescence very different.

A few monstrous flowers were found like those described by Grisebach as occurring in Bucida Buceras L. Collected on the savannas at Red Bays in April and near the source of Fresh Creek in June, no. (502).

Plate r3. Terminalia spinosa. Portion of plant, natural size; $n$, cluster of flowers; $a$, flowers showing disk; $p$, stamen.

Buceras Catappa (L.) A. S. Hitch. "Almond tree." Nassau, Jan. Cultivated.

\section{MeLastomace $e$}

Tetrazygia Bicolor (Mill.) Cogn. (T.elcagnoides DC.) Common in the pines on both islands. Nassau, Jan.; Conch Sound, May (I27). Same as Wright I222.

\section{ONAGRACE $\mathbb{E}$}

Jussiza suffruticosa L. Near Southwest Beach, N.P., Feb. (320). - Same as Wright I59.

\section{SAMYDACE $A$}

Casearia latroides (Rich.) Cocoanut Point, Andros, April (5I4). Same as Wright IIo8.

Casearia BaHamensis Urban. Nicol's Town, March, April (384). Distributed as Thioidia serrata Endl.

Banara Reticulata Gris. Conch Sound, May (558). Same as Wright I882. Determined at Kew by Dr. N. L. Britton. 


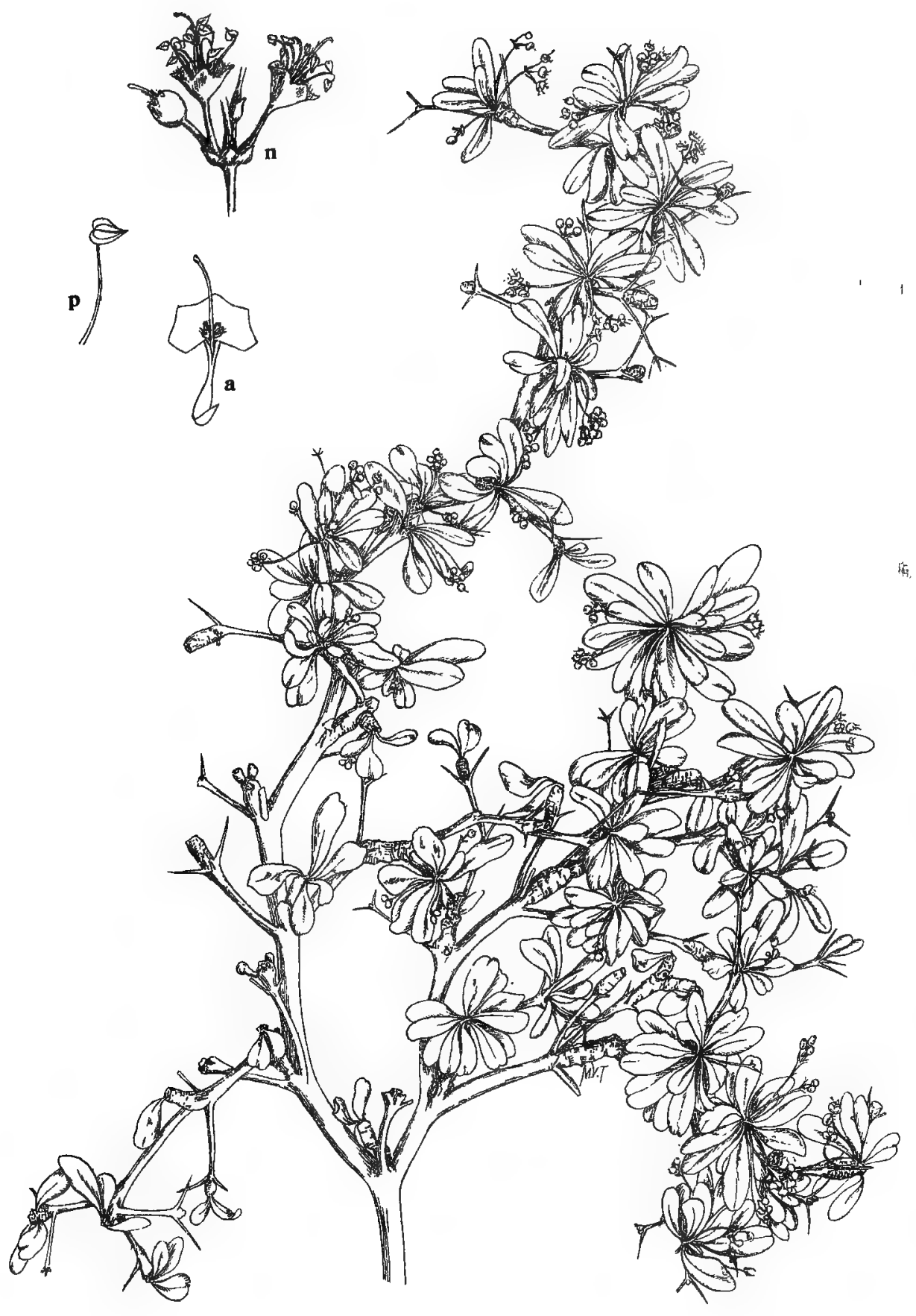





\section{UMBELIIFER庄}

Hydrocotyle pygmea Wright. Red Bays, Conch Sound, April (499, 524). Determined at Gray herbarium by Mr. J. M. Greenman.

Centella Asiatica (L.) Urban. (Hydrocotyle Asiatica L.) In low ground in the pines. Red Bays, April (494).

Anethum graveorens L. "Dill-seed." Nicol's Town, April. Escaped (438).

\section{Myrsinace}

Rapania Guyanensis Aubl. (M. Floridana A. DC.) Nicol's Town, March (387).

ICACOREa Paniculata (Nutt.) Sudw. (Ardisia Pickeringia T. \& G.) "Stopper-tree." New Providence, Jan. (234). Same as Curtiss I799.

Jacquinia Keyensis Mez. "Joe-bush," "iron wood." Common on the cays and along the eastern shores of both islands. Rose Island, N.P., Feb.; Fresh Creek, June; Mars Bay, July (25I). A new species described in Symbolæ Antillanæ, I8go.

\section{PrIMULACE e}

Samolus Ebracteatus Kunth. Common on the savannas at Red Bays, April (478).

\section{Plumbaginace $x$}

Plumbago scandens L. Common about Nassau, Jan. (i I).

\section{SAPOTACE压}

Chrysophyllum oliviforme Lam. "Saffron-tree." In the pines on both islands. New Providence, Feb. (262).

Bumelia Cubensis Griseb. London Creek, Andros, May. In fruit only. "Rather small-leaved." Determined by Dr. B. L. Robinson, Gray herbarium (544).

BUMelia Microphylla Griseb. In the swash on the west side of Andros. In fruit only. Purser Point, June (666). Same as Brace 234 and Eggers 44I8. Determined by Dr. Britton at Kew.

Lucuma PaUCiflora A. DC. "Egg fruit." Deep Creek, June (703). Same as Wright 346. 
Sideroyxlon mastichodendron Jacq. In fruit. Cocoanut Point, Andros, April (450). Same as Wright I324.

Dipholis SALICIFOLIA A. DC. "Wild cassada," "bustic." Common in the coppet on both islands. Nassau, Feb.; Fresh Creek, June; Deep Creek, July (326). Same as Eggers 4106.

Mimusops dissecta R. Br. "Wild sapodilla." Common near the shore on both islands. Hog Island, N.P., Feb. (263).

Mimusops Floridana Engelm. "Wild sapodilla." Conch Sound, May; Deep Creek, July (734). Same as Curtiss I 766, Determined at Kew by Dr. N. L. Britton.

Achras Sapota L. "Sapodilla." Common in cultivation. Nassau (42).

\section{EBENACE}

Maba Caribeea (A. DC.) Hiern. (Macreightia.) Fresh Creek, June (640). Same as Wright I33I.

\section{OLEACE $A$}

Adelia Porulosa (Poir.) Engler. Savannas back of Red Bays. April (5II). Determined by Dr. B. L. Robinson, Gray herbarium.

Adelia sp. Coppet, Conch Sound, May. Staminate flowers only. Near $A$. porulosa, but leaves are broader, I. $5^{-2} \mathrm{~cm}$. wide, $5 \mathrm{~cm}$. long, more tapering at the base and apex; veins inconspicuous. not shining above; filaments broader (589).

\section{LOGANIACE}

Spigelia Anthelmia L. Mastic Point, May (599). Same as Wright 390.

Cynoctonum Mitreola (L.) Britton. (Mitreola petiolata T. \& G.) In savannas on the west side of Andros. Differs from all specimens examined in having the branches of the cymes much more divergent, and the inflorescence scarcely, if at all, unilateral. Red Bays, April (492).

Cynoctonum sessilifolia (T. \& G.) Britton. $\mathrm{I} 2-\mathrm{I} 5 \mathrm{~cm}$. in

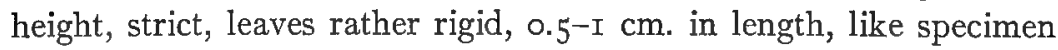
from East Florida collected by Palmer, no. 436; also like specimen from Key West (573). In savannas on west side of Andros, Red Bays, April. 


\section{Gentianace e}

Eustoma exaltatum Griseb. Abundant in the savannas on the west side of Andros; occurs sparingly elsewhere. New Providence, Jan.; Red Bays, April (201, 456).

Sabbatia campanulata (L.) Torr. (S. gracilis Salisb.) Quite common on both islands. On New Providence growing in sand near the shore; on Andros on the savannas near Red Bays and also near fresh water in the interior. Very variable, flowers often white. Hog Island, N.P., Feb.; Red Bays, April; Stafford Creek, May $(322,464,744)$.

Voyria Mexicana Griseb. Conch Sound, March (4I5).

\section{APOCYNACE}

Vinca rosea L. Nassau, Jan. (Irr).

Plumiera obtusa L. "Frangipani," "milkweed." Not uncommon near the shore. Fresh Creek, June (65I).

Echites ANDrewsil Chapm. "Wild unction." Common. Conch Sound, April, May (522).

Echites BIFLORA Jacq. Conch Sound. Collected by Mr. Alexander Keith, I892 (740). Same as Eggers 2676.

Echites Sagrex A. DC. Common. Nassau, Jan.; Conch Sound, March; Red Bays, April (I28, 43I, 46I).

ECHITES UMBELlata Jacq. "Devil's potato-root," "dreamvine." Very common and variable; leaves range from lanceolate to orbicular, 2-10 $\mathrm{cm}$. in width. Nassau, Jan.; Conch Sound, March; Red Bays, April; Deep Creek, June (6I, 403, 673).

Plumiera rubra L. "Frangipani," "jessamine tree." Mastic Point (60I).

Thevetia Thevetia (L.) Millsp. Cultivated at Nassau (75).

\section{ASCLEPIADACE $\mathbb{E}$}

Asclepias Curassavica L. Common about Nassau, Jan. (2I). Metastelma Bahamense Griseb. Conch Sound, March (4Io).

Metastelma barbatum sp. nov.

Stem smooth, twining; leaves linear or linear-lanceolate, occasionally oblong, $I-2.5 \mathrm{~cm}$. in length, $2-3 \mathrm{~mm}$. in width, apex cuspidate 
or obtuse and mucronate, occasionally acute, base obtuse, margin entire, slightly thickened, midrib prominulous on the under side, petioles $2-3 \mathrm{~mm}$., umbels five- to eight-flowered, peduncle I-I.5 $\mathrm{mm}$., pedicels about I $\mathrm{mm}$.; calyx lobes smooth, ovate, obtuse, about one-fourth the length of the corolla; corolla greenish white, urceolate-campanulate; petals lanceolate-oblong, obtuse, united about one-third of the way, the upper third densely villous within and with a few scattered hairs in the center of the petal below, crown segments attached to the base of gynostegium and of the corolla, equaling the column in length, somewhat incurved, ligulate, bifid at the apex, teeth often unequal, rarely obtuse; gynos tegium about half as long as the corolla; stigma depressed; follicle slender, acuminate, $3 \mathrm{~cm}$. in length (474).

Plate I4. Metastelma barbata. Portion of plant; $e$, crown; $u$, calyx and pistil; $c$, petals; $h$, part of gynostegium; $p$, pollinia.

A low, twining plant, common on the savannas near Red Bays on the west side of Andros, April I5. The same as a specimen at Kew collected by Governor Robinson in the pine barrens of New Providence, April, 1877.

The species is closely related to Metastelma Blodgettii Gray, but differs in having no lines of pubescence on the stem, umbels $5^{-8-}$ flowered, peduncles and pedicels shorter and the flowers smaller with the calyx shorter in proportion to the corolla, scales of the crown slightly incurved, broader and toothed at the apex.

Metastelma Palustre Schltr. (Seutera maritima Decsn.) Hog Island, N.P., Feb.; Red Bays, April $(333,475)$.

\section{Convolvulace e}

Iтomce Batatas Lam. "Sweet potato." Cultivated and escaped on both islands. Nassau, Jan. $(77,223)$.

Ipomcea CAthartica Poir. Nassau, Jan. (220). Determined by Dr. Britton at Kew.

Ipomaca coccinea L. Nassau, Jan. (I 20).

Ipomcea commutata R. \& S. Nassau, Jan. (23I).

Ipomca fastigiata Sweet. Nicol's Tówn, April (518). Compared at Kew by Dr. Britton. Same as Eggers 4370, 454I from Bahama.

Ipomca heptaphylda Griseb. In the pines. Conch Sound, May (569). Same as Wright I37I. 


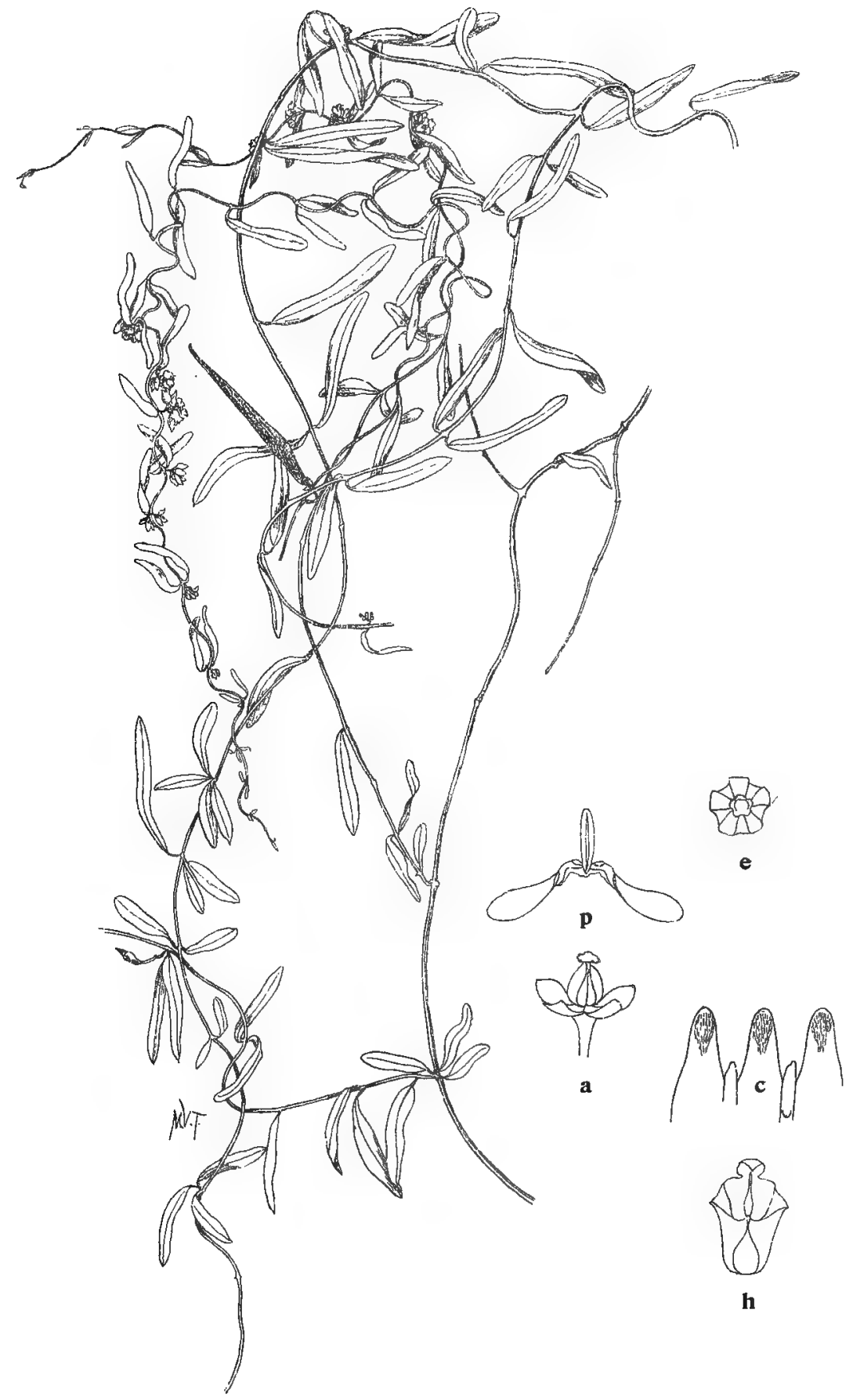

METOSTELMA BARBATA 

IPOMœA Jamaicensis Don. "Glory-morning." Common and very variable. Nassau, Feb.; Conch Sound, April; Fresh Creek, June; Mars Bay, July (77, 254, 45I, 623, 710). Determined by Dr. Britton at Kew.

IPOMCEA GRANDIFLORA Lam. (I. longiflora R. Br.) On sandy beaches. Salt Cay, N.P., Jan.; Deep Creek, June (244).

IPOMGa PES-CAPRe (L.) Sweet. "Bay-hop." Very common on sandy shores on both islands. Cocoanut Point, Andros, May (533).

IPOMEA REPANDA Jacq. (I. arenaria Steud.) Common in the pine-yard. Conch Sound, March (394, 404). Same as Wright 3ro2. No. 394 has the leaves deeply cordate at base.

Iтомса sidrfolia Chois. "Christmas gambol," "Christmasflower." Common about Nassau. Nassau, Jan. ( ( 3 ).

Ipomcea sinuata Ort. ( $I$. dissecta Pursh.) Common in the coppet on both islands. Nassau, Jan.; Fresh Creek, June $(16,76)$.

Ipomca Triloba L. Conch Sound, March; Fresh Creek, June. Leaves $1.5^{-2} \mathrm{~cm}$. long, plant smaller and more delicate than any specimens examined; closely resembles an unnamed specimen of Blodgett's from Key West, in Torrey herb (423).

Jacquemontia Jamaicensis (Jacq.) Hall. Common on both islands. Nassau, Jan. (I35).

Jacquemontia verticillata (L.) Urban. Conch Sound, March (424). Same as Wright 455 .

Evolvulus arbuscula Poir. Fresh Creek, June (607). Resembles Wright 1658 ; differs from Wright 456 in being more slender, not as erect, flowers smaller, 3-4 mm., white; calyx and corolla sericeous; calyx shorter, about $\mathrm{r} .5 \mathrm{~mm}$. long. Plant about $6 \mathrm{dm}$. in height, leaves $\mathrm{I}-2 \mathrm{~mm}$. long.

DichoNDRA REPENS Forst. Nassau, Jan. (I 72 ). Same as Wright 459 .

\section{Cuscutace $\mathbb{E}$}

Cuscuta Americana L. Growing on shrubs in low ground. Red Bays, April (497). Same as Wright I659.

\section{HYDROPHYLLACE $\mathbb{E}$}

Nama Jamaicense L. Nassau, Jan. (I66). 


\section{BORAGINACE $A$}

Cordia angustifolia R. \& S. Fresh Creek, June (6I9). Agrees with Wright 3 II4 except in having spatulate leaves and surface much less pubescent.

CoRdia lima R. \& S. "Granny-bush." Common on Andros. Nicol's Town, March (376). Ex. desc.

Cordia Sebestena L. Common along shore on both islands. Same as Cooper $5^{2}$; agrees with Wright 3554 except in the shape of the leaves. All the Bahaman specimens examined have the leaves oval instead of ovate (IO7).

Bourreria Havanensis (Willd.) Miers. "Strong-back." Common on both islands in the pines and coppet. Nassau, Jan.; London Creek, May; Fresh Creek, June $(74,542)$.

Tournefortia gnaphalodes (Jacq.) $R$. Br. Common on sandy beaches on both islands. Nassau, Jan. $\left(6_{3}\right)$.

Tournefortia volubilis L. Nassau, Jan.; common on both islands (2I2).

Heirotropium Curassavicum L. Nassau, Jan.; Middle Bight, Andros, June (Ig8).

Heliotropium Parviflorum L. Nassau, Jan. (24).

\section{Heliotropium nanum sp. nov.}

Low, shrubby, corymbose-branching, 8-II cm. high, branches erect-ascending, entire plant strigose-canescent; leaves numerous, appressed, alternate, sessile, about $2 \mathrm{~mm}$. long and I $\mathrm{mm}$. wide, elliptical-oblong in shape, acute, margin entire; flowers scattered, solitary, sessile, about as long as the leaves and opposite them; calyx persistent, segments 5 , imbricate, slightly unequal, lanceolate, acute, about I mm. in length, strigose-canescent; corolla white, campanulate, shortly exceeding the calyx, hairy on the outside, lobes 5, ovate-oblong; stamens inserted about the middle of the corolla tube, anthers lanceolate, appendiculate appendage almost as long as the anther, disk flat, ovary free, globose; style short; stigma annular with a conical tip; fruit depressed-globose, separating into four one-seeded, hairy nutlets; seeds curved (757).

Collected at Red Bays on the savannas. In flat, rather marly ground near the shore. 


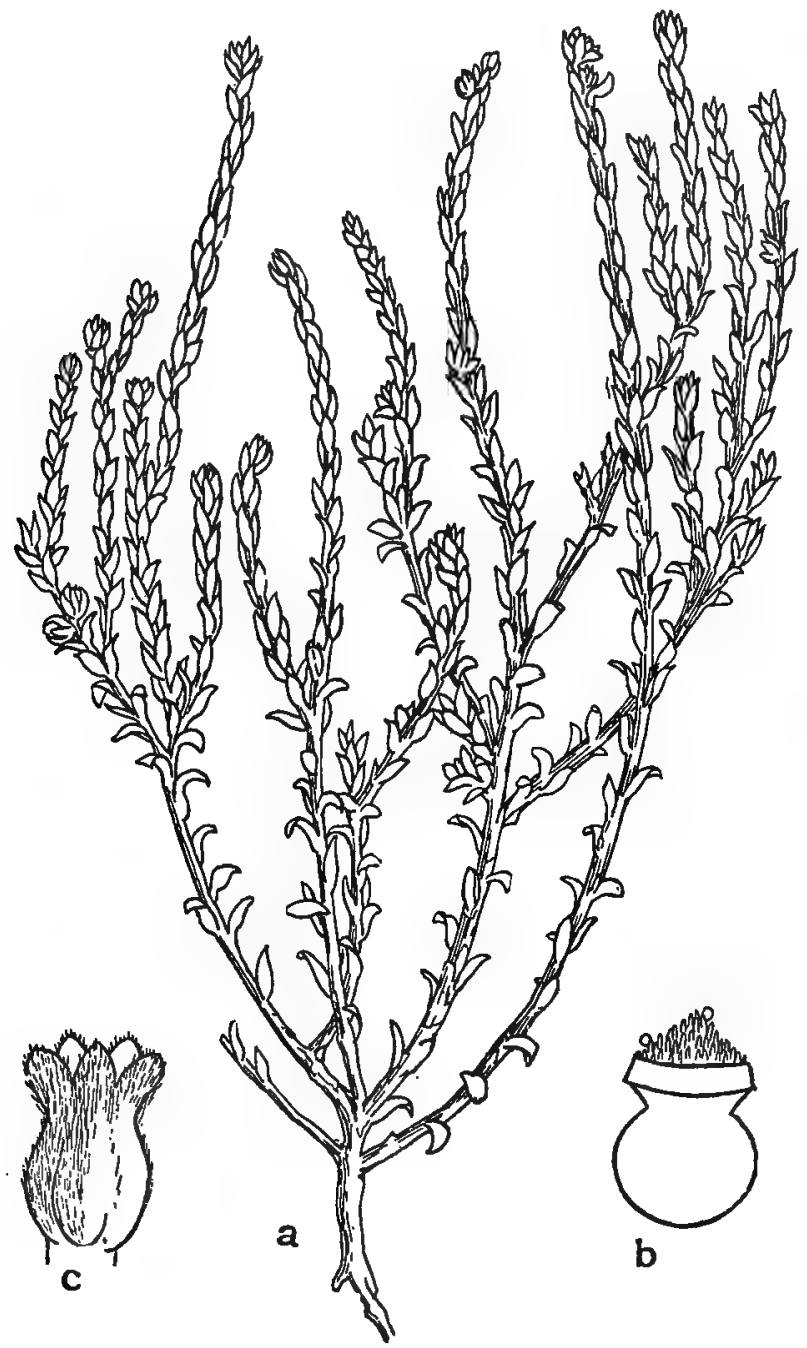

Heliotropium manum. $a$, Plant $\times \frac{4}{3} ; b$, ovary; $c$, calyx.

\section{VERBENACE $\bar{A}$}

Lantana Camara L. Not uncommon. Nassau, Jan.; Red Bays, April (I29, 490).

Lantana CRocea Jacq. Nicol's Town, March; Conch Sound, May $\left(35^{2}, 56 \mathrm{I}\right) . \quad 35^{2}$ has larger leaves, $3.5-4.5 \mathrm{~cm}$. in length, and shorter peduncles $\left(\mathrm{I} .5^{-2} \mathrm{~cm}\right.$.) and may be $L$. polyacantha Schauer, 
as it much resembles a specimen collected by Eggers at St. Thomas and so named by Watson.

Lantana involucrata L. "Wild sage," "big sage." Common on both islands. Fort Montague, Nassau, Jan. (56).

LipPIA CANEScENS Kth. Nassau, Jan. (II4).

Lippia Nodiflora (L.) Michx. Hog Island, N.P.; Red Bays, April (250, 48I). Same as Eggers I537, St. Domingo (unnamed).

Abena Jamaicensis (L.) A. S. Hitch. (Stachytarpha Vahl.) Roadsides, Nassau, Jan. (Ig).

Citharexylum Berterit Spreng. Calabash Cay, Andros, June (608). Leaves much longer than in Wright (I356), I0-I $2 \mathrm{~cm}$. long, $\mathrm{I}-2.5 \mathrm{~cm}$. wide.

Citharexylum lucidum Cham. \& Schlecht. Leaves oblanceolate, cuneate at base, shining and leathery when old, apex obtuse or emarginate, corolla puberulous, raceme erect in fruit. Conch Sound, May (57I).

Duranta Repens L. (D. Plumieri Jacq.) Common on both islands. Nassau, Jan. (39).

Petitia Domingensis Jacq. Nicol's Town, March (358). Compared at Kew by Dr. Britton. Same as Eggers 4203 and Robinson 55 .

Vitex ILICIfolia Rich. Fresh Creek, June (625). Determined at Kew by Dr. Britton. Same as Wright 3 r8o.

AVICENNIA NITIDA Jacq. "Salt bush," "black mangrove." Common in the swash and along the shore. Mastic Point, May (593).

Ovieda FRagrans (W.) A. S. Hitch. (Clerodendron.) "Wild jessamine." New Providence, along the roadside. Naturalized. Feb. (328).

Ovieda Aculeata (L.) A. S. Hitch. Nassau, March. Escaped? (296).

\section{LABIATA}

Micromeria BrowneI Benth. Conch Sound, April (526). Petioles 4-5 mm., equaling or exceeding the leaves and peduncles: under surface of leaves and stem purplish.

Salvia occidentalis Sw. New Providence, Feb. (265).

Salvia Serotina L. Silver Cay, Nassau, Jan. (I 57). 
Leonurus Sibiricus L. Common about Nassau, Jan. (2).

LeONOtis NePeTAfFolia (L.) R. Br. Nassau, Jan. (3I).

Teucrium Cubense L. Nassau, Jan. (IO8).

Mesospherum Pectinatum (Poit.) Kuntze. Red Bays, Andros, April (5०5).

\section{Solanace}

Solanum aculeatissimum Jacq. Nassau, Jan.; Fresh Creek, June.

Solanum BaHamense L. "Cankerberry." Common on both islands. Variable. Nassau, Jan.; Salt Cay, Jan. (I74, 24I). I74 has prickles on both veins and midrib of the leaves as well as on the stems while $24 \mathrm{I}$ is entirely unarmed and has racemes ro-r $2 \mathrm{~cm}$. long, recurved at the apex.

Solandm Nigrum L. Nassau, Jan. (126, 228).

SOlANUM NIGRUM NODIFLORUM Gray. Conch Sound, May; Fresh Creek, June (557, 6I4).

SOLANUM VERBASCIFOLIUM L. "Salve-bush." Common on both islands. Nassau, Jan. ( $13 \mathrm{I}$ ).

Physalis angulata L. Fresh Creek, June (6I6).

Physalis Barbadensis Jacq. Conch Sound, March (42I).

Capsicum baccatum L. "Bird-pepper." Hog Island, N.P., Feb. (256).

Cestrum Pallidum Lam. Nicol's Town, April (432).

Datura Metel L. Deep Creek, June. Probably escaped (700).

\section{SCROPHULARIACE $\Psi$}

ANTIRRHINUM ANTIRRHINIFLoRA (Willd.) A. S. Hitch. ( $A$. maurandioides Gray.) Nassau, Jan. Probably escaped (95).

Russelia Juncea Zucc. Escaped. Nassau, Jan. (I22).

Stemodia maritima L. Nassau, Jan. (265).

Capraria BIflora L. Common on both islands. Nicol's Town, March $\left(27,3^{8 I}\right)$.

Buchnera elongata Sw. Common on savannas on the west side of Andros. Red Bays, April (467).

Gerardia maritima Raf. Common on savannas on west side of Andros. Red Bays, April; Purser Point, June. Variable (75I). 


\section{FLORA OF NEW PROVIDENCE AND ANDROS}

Gerardia purpurea L. 4-4.5 dm. in height, mostly simple and strict. Red Bays, April (459).

\section{LENTIBULARIACE $\approx$}

UtRICULARIA FOliosa L. Stafford Creek, Andros, May. "No certain determination possible without flowers: the bladders appear like those of $U$. foliosa which is common in the West Indies." Dr. Thomas Morong $(543,547)$.

Utricularia gibBa L. Stafford Creek, Andros, May. No flowers. "Leaves and bladders much resemble those of $U$. gibba which occur in Florida." Dr. Thomas Morong (548).

Pinguicula pumila Michx. Rare; on the edge of the swash on the west side of Andros. Red Bays, May (572).

\section{BigNONIACE 2}

Tecoma lepidophylla Griseb. Purser Point, Andros, June (660). Same as Wright I34I.

Tecoma sp.

Medium-sized shrub, twigs rusty-lepidote; leaves digitate, with three or five leaflets, petioles I-2 cm. long, channeled above, sparingly rusty-lepidote, petiolules $2.5 \mathrm{~mm}$. long, central, one-half as long again as the lateral; leaflets $2.5-4.5 \mathrm{~cm}$. long, $1.5-2.5 \mathrm{~cm}$. broad, obovate or oval, retuse or emarginate and mucronate at apex, obtuse and usually unequal at base, margin crenulate, veins prominent below; leaves thick, sparingly lepidote above; scales abundant beneath, the larger ones rusty, giving the under surface a slightly brownish tint; flowers not seen; calyx bilabiate, rusty-lepidote, at length deciduous, 7-10 $\mathrm{mm}$. in length, lobes acute; capsule linear, pointed, subcompressed, 6-9 cm. long, rusty-lepidote; valves slightly keeled.

Collected at Long Ridge Cay, Andros, June 20 (758).

Tecoma Bahamensis sp. nov. "Beef-bush"

A tall shrub, twigs light brown, lepidote; leaves opposite, palmately compound, with five leaflets, petioles $3-5 \mathrm{~cm}$. in length, flattened and channeled above; leaflets all petiolulate, petiolule of the central leaflet about I cm. in length, being slightly longer than those of the lateral leaflets and more than twice as long as those of the basal leaflets, leaflets oblong or oblong-elliptical, sometimes oblanceolate, $2-4 \mathrm{~cm}$. long, I-2.5 $\mathrm{cm}$. wide, the central leaflet largest, 

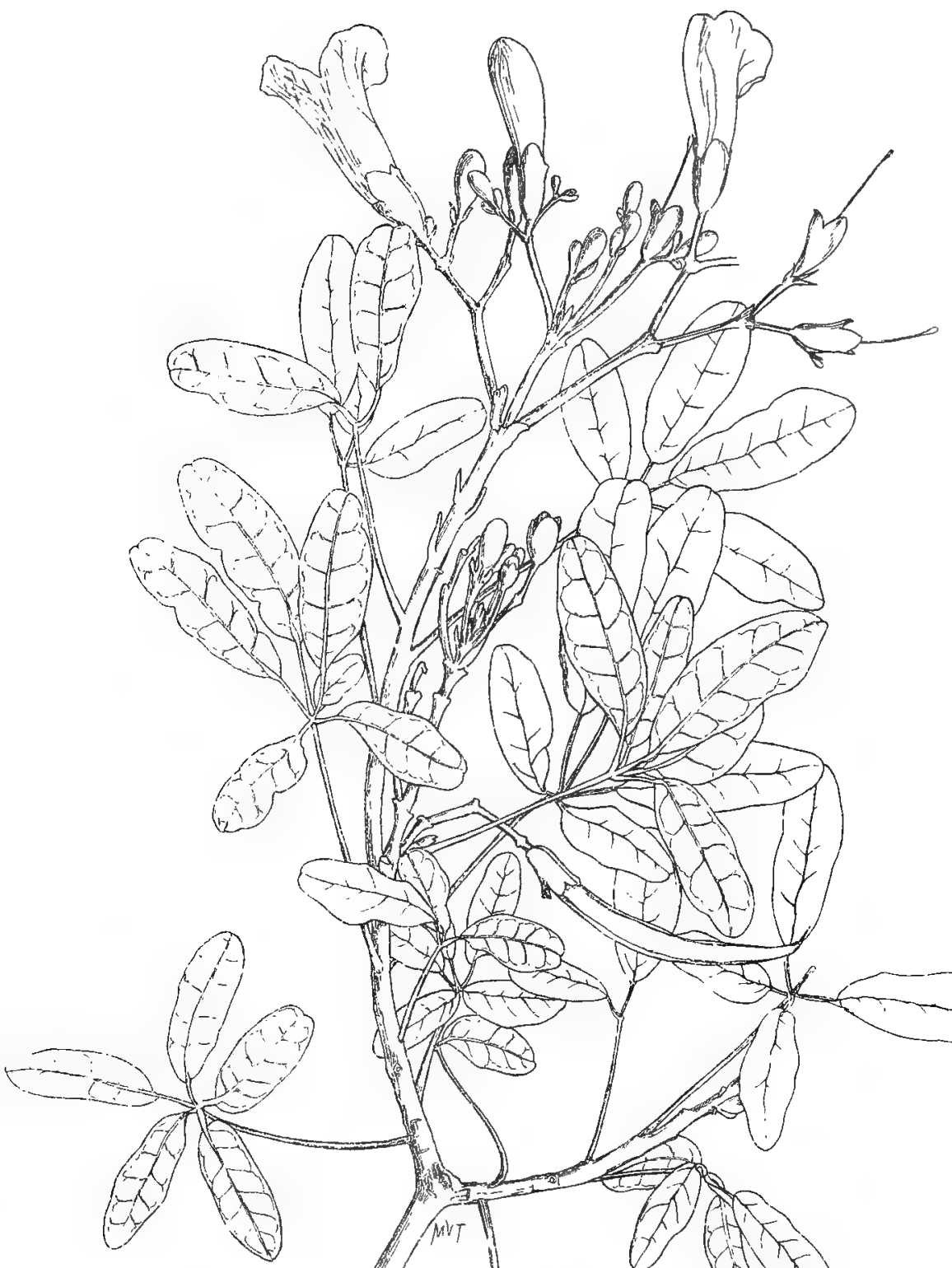

(2)

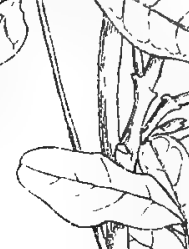

$<$ 

thickish, apex obtuse or retuse, margin entire or slightly undulate, veins prominulous beneath, $4-7$ pairs diverging from the midrib at nearly right angles, surface lepidote on both sides, pale green above, white beneath owing to the confluent white scales; inflorescence terminal, sessile, many-flowered cymes; flowers showy, pale pink, pedicels rusty-lepidote, about $\mathrm{I} \mathrm{cm}$. in length; calyx rusty, campanulate, closed in the bud, about I.5 cm. in length, bilabiate, lower lip subtruncate, upper longer, usually rounded; corolla funnel-shaped, veiny, pink, about four times as long as the calyx, limb spreading, lobes rounded, slightly unequal, margin sometimes undulate, tube pubescent within; stamens 4 , didynamous, less than half the length of the corolla, inserted near the base of the tube, filaments incurved, anther cells linear-oblong, divaricate, straight; pistil about $2.5 \mathrm{~cm}$. in length; ovary lepidote, two-celled; style slender; stigma twolamellate, lamellæ cuneate or obovate; disk pulvinate; capsule elongated, linear, about $8 \mathrm{~cm}$. in length and $7-8 \mathrm{~mm}$. in width, slightly compressed; rusty-lepidote, valves coriaceous, subcarinate, veiny; seeds oblong, slightly notched below, about as long as the striate hyaline wing (2I8).

Collected on New Providence, near Nassau, Jan. 26; in the interior of the island, Feb. 26, and at Nicol's Town, Andros, March 26.

Note from Kew, 1899: "This matches a plant collected in the Bahamas by Brace no. 643 and Eggers no. 3962 which has been called Tabebuia leucoxyla DC., but according to Bureau T. leucoxyla is identical with $T$. obtusifolia Bureau, a totally different plant with simple leaves." Also resembles a specimen at Cambridge from the Bahamas 1859 marked T. leucoxyla? by Gray.

Plate 15. Tecoma Bahamensis. Portion of plant in flower, $\times \frac{3}{4}$.

Tecoma stans (L.) Juss. "Yellow elder." Common about Nassau, Jan. (8).

JACARANDA BAHAMENsis R. Br. "Boxwood," "cancer tree." Deep Creek, June (7or). Determined at Kew by Dr. Britton.

Jacaranda cGerulea Griseb. Nassau, Jan. (213). Same as Eggers 4427.

\section{ACANTHACE $\mathbb{E}$}

Thunbergia fragrans Roxb. Probably escaped. Nassau, Jan. ( 130$)$.

Blechum Brownei Juss. Nassau, Jan. (49).

Anthacanthus acicularis (Sw.) Nees. Common in the coppet 
on Andros. Nicol's Town, April; Fresh Creek, June (396). The same as a specimen of Cooper's from New Providence.

Dicliptera ASSURgens Juss. Nassau, Jan. (72).

\section{RUBIACE E}

Exostemma Caribaum (Jacq.) R. \& S. "Princewood." Kemp Sound, Andros, June (685). Same as Wright 2674 and Curtiss I 32 .

Rhacicallis Americana (Jacq.) A. S. Hitch. (R. rupestris DC.) "Sand-fly bush," "salt-water bush," "seaweed," "wild thyme." Common along the rocky shores of both islands. Red Bays, April; Fresh Creek, June (458). Same as Wright 2696.

Hamelia patens Jacq. Nassau, Jan. (40). Same as Curtiss 5500 from Florida.

Catesbea spinosa L. "Prickly apple." Fresh Creek, June (624).

\section{Catesbæa fasciculata sp. nov.}

A low, spiny shrub with long, slender branches; leaves fascicled, obovate or oblanceolate, $5.7 \mathrm{~mm}$. in length, $3-4 \mathrm{~mm}$. in width, obtuse, tapering into a short petiole at base, thick, shining above, margin entire or slightly revolute, surface of the stem, spines and upper surface of leaves minutely papillose; spines axillary, slender, in pairs, about as long as the leaves; flowers scattered, small, solitary, sessile in the axils; calyx-tube short, ovoid, lobes 4, subulate, persistent; corolla valvate, campanulate, white, 5-7 mm. in length, lobes 4, short, I-2 mm. long, obtuse, spreading; stamens 4, inserted at the base of the corolla tube, filaments glabrous, slightly exceeding the tube, anthers linear, ovary 2-celled, 2-flattened, pendulous ovules in each cell; style smooth, a little longer than the stamens; fruit (immature) a berry.

Collected at Fresh Creek, Andros, June 6. The same as Eggers 4508 from Hog Island (627).

Plate r6. Catesbra fasciculata. Portion of plant, about natural size; o, flower with corolla removed; $n$, interior of corolla showing stamens.

Scolosanthus sp.

A low, tortuous branching shrub, slightly resinous, with slender scattered spines, $5^{-6} \mathrm{~mm}$. in length; leaves and stem minutely papillose; leaves fascicled or opposite, minute, $2-2.5 \mathrm{~mm}$. in length, short-petioled, ovate, obtuse with revolute margins, thick, shining; stipules small, connate; flowers not seen; drupe ovoid or globose, 
Oe

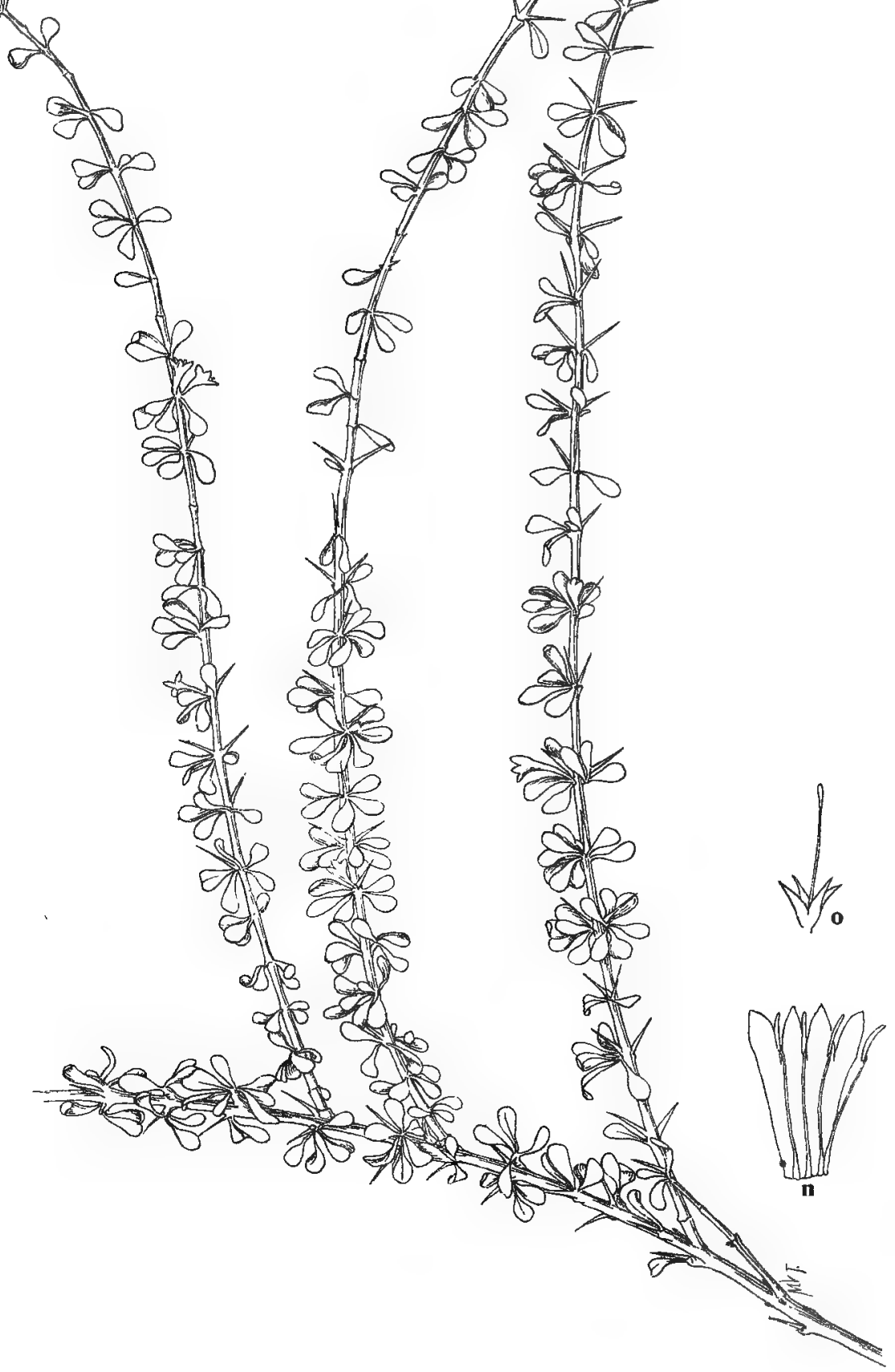



sessile, axillary, white, about $2 \mathrm{~mm}$. in length, and containing one compressed seed.

A single specimen collected on the south side of Fresh Creek, Andros, June (646).

Randia aculeata L. Common on both islands. Nicol's Town, March (383). Same as Wright $39^{2}$ and Curtiss II29.

Genipa Clusiefolia (Jacq.) Griseb. "Seven-year apple," Spruce Cay, N.P., Feb.; Mastic Point, Fresh Creek, June (299). Same as Wright 3574 and Curtiss II 30.

Guettarda Elliptica Sw. Stafford Creek, Andros, May; Lisbon Creek, June $(540,677)$.

GuetTarda scabra Lam. Stafford Creek, May; Fresh Creek, June; Conch Sound, July $(535,649,730)$. The specimens from Stafford and Fresh Creek 535 and 649 are identical but differ greatly from $73^{\circ}$; the former have thicker, rigid leaves, paler in color, with an entire revolute margin and the veins prominently raised on the under surface. No. 730 has the leaves strongly mucronate, margin crenate and the upper surface much more scabrous than in Wright 2707. No. 730 is the same as Brace I86 and I97 as compared at Kew by Dr. Britton.

ANTIRRHœA IUCIDA Gaertn. Deep Creek, July (724). Same as Wright 1270 .

ANTIRrhec MYRTIfolia Griseb. Red Bays, April; Fresh Creek, June (470). Same as Wright 2782 and Brace 445. Determined at Kew by Dr. Britton.

ERITHALIS FRUTicosa L. "Black torch." Common on both islands. Nicol's Town, March; Red Bays, April; Deep Creek, June $(365,482,69 \mathrm{I})$. Same as Curtiss II 27 .

Erithalis Rotundata Griseb. Deep Creek, June (739). Same as Wright I 268.

Chiococca PARvifolia Wulschl. "Snake-root." Common in the coppet on both islands. Nassau, Jan.; Deep Creek, June ( 138,688$)$. Same as Wright $35^{84}$.

Chiococca Alba (L.) A. S. Hitch. (C. racemosa Jacq.) Nassau, Jan. (28).

Chiococca sp. Red Bays, April (477).

The latter was a depressed form found in the savannas on the west side of Andros. Stems erect, unbranched; plant low, about 3 
$\mathrm{dm}$. in height, with smaller, thicker, more rigid leaves, lanceolate with a blunt apex, $2-2.5 \mathrm{~cm}$. long; flowers yellowish brown. Resembles a specimen of Blodgett's from Key West in the Gray herbarium.

Phialanthus myrtilloides Griseb. "Candlewood." Stafford Creek, May; Fresh Creek, June (541, 642, 728).

STRUMPFia MARitima Jacq. Common on the cays and along the shores of both islands. Nassau, Jan.; Lisbon Creek, Andros, June (I5I).

MoRINDA Royoc L. "Wild mulberry," "wild pineapple." Not uncommon in the pines on Andros. Conch Sound, March (425). Same as Wright 2757 . Plants I.5-2 $\mathrm{m}$. in height.

Myrstiphyllum pubescens (Sw.) A. S. Hitch. (Psychotria.) Conch Sound, May (585). Same as Wright 243 and 1278.

Myrstiphyllum undatum (Jacq.) A. S. Hitch. (Psychotria.) "Wild coffee." Nicol's Town, March (36I).

\section{Myrstiphyllum ligustrifolium sp. nov.}

A low shrub with smooth dark bark; branchlets slightly angled; leaves opposite, petioles $2-4 \mathrm{~mm}$. in length, blade elliptical or oblanceolate, $3-6 \mathrm{~cm}$. long, I-2 $\mathrm{cm}$. broad, thickish, paler beneath, apex acuminate, base cuneate or tapering, margin entire, slightly revolute, glabrous or with a few scattered hairs beneath on the midrib or in the axils of the veins, veins rather inconspicuous above; stipules rusty membranaceous, truncate, sheath deciduous, about $5 \mathrm{~mm}$. in length; flowers in three- to five-rayed terminal panicles, peduncle about $2 \mathrm{~cm}$. in length, pedicels about I $\mathrm{mm}$. or flowers sessile, bracts minute, ciliate; calyx deciduous, tubular-campanulate, I-2 $\mathrm{mm}$. long, lobes 5, very short, acute, ciliate; corolla whitish, somewhat funnel-form, about three times as long as the calyx, throat bearded, lobes 5 , valvate, half as long as the tube, lance-oblong, obtuse, thickened and involute at the apex, at length reflexed; stamens 5 (6), inserted in the throat of the corolla, included, filaments short, anthers oblong; ovary two-celled, globose; style smooth, dilated upwards, two-cleft at apex; drupe dark red, globose or ovoid, 5-6 mm. high, 4-5 mm. broad, pyrenæ flat, four-furrowed, crests broadly obtuse (206).

Collected at two places in the neighborhood of Nassau, Jan. The same as Eggers $405^{2}$ from Hog Island. It is related to $M$. celastroides Gris.

Plate I7. Myrstiphyllum ligustrifolium. Branch in leaf and flower, about natural size; $h$, fruiting branch; $s$, single flower; $a$, interior of corolla showing stamens; $c$, pistil. 


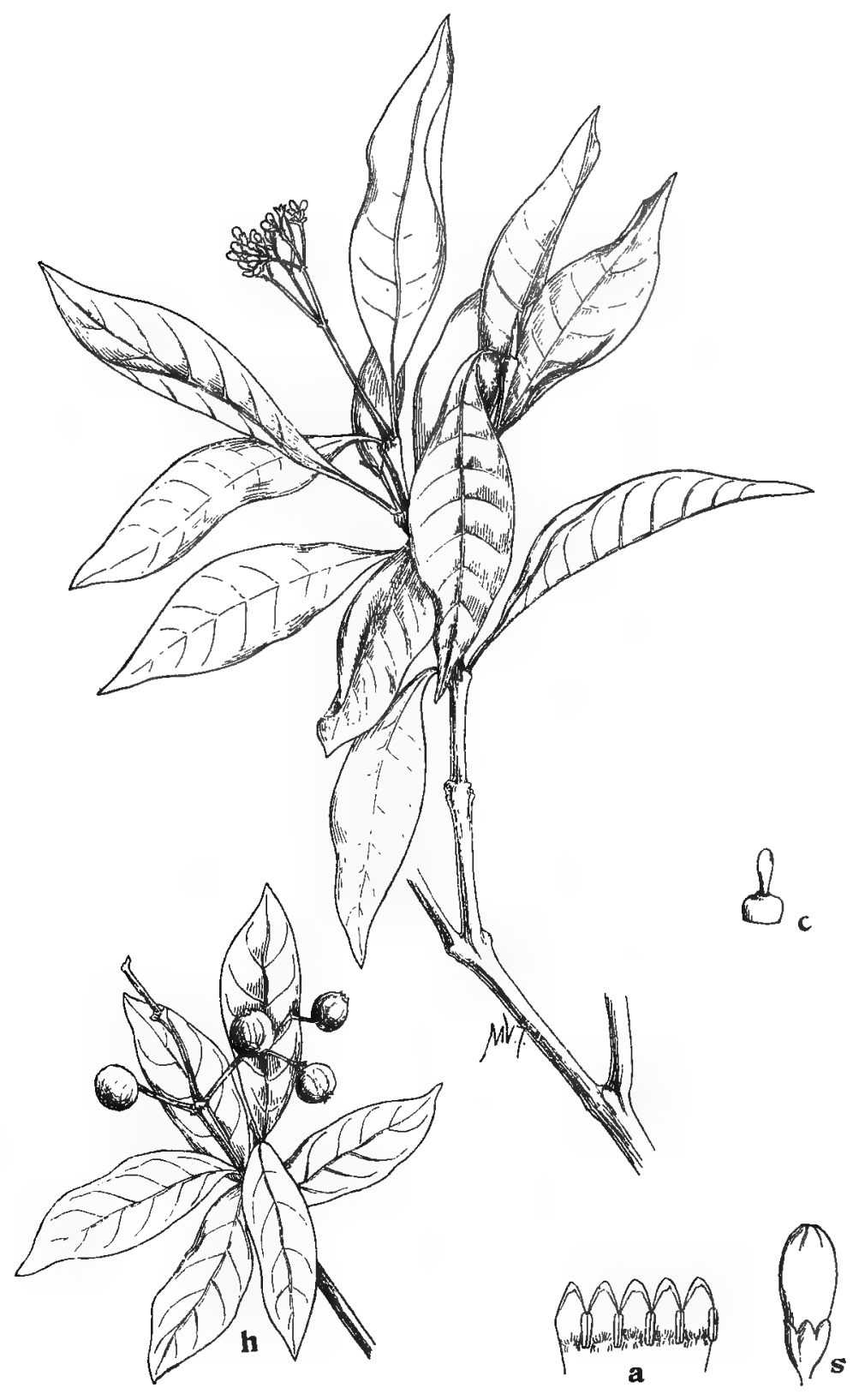





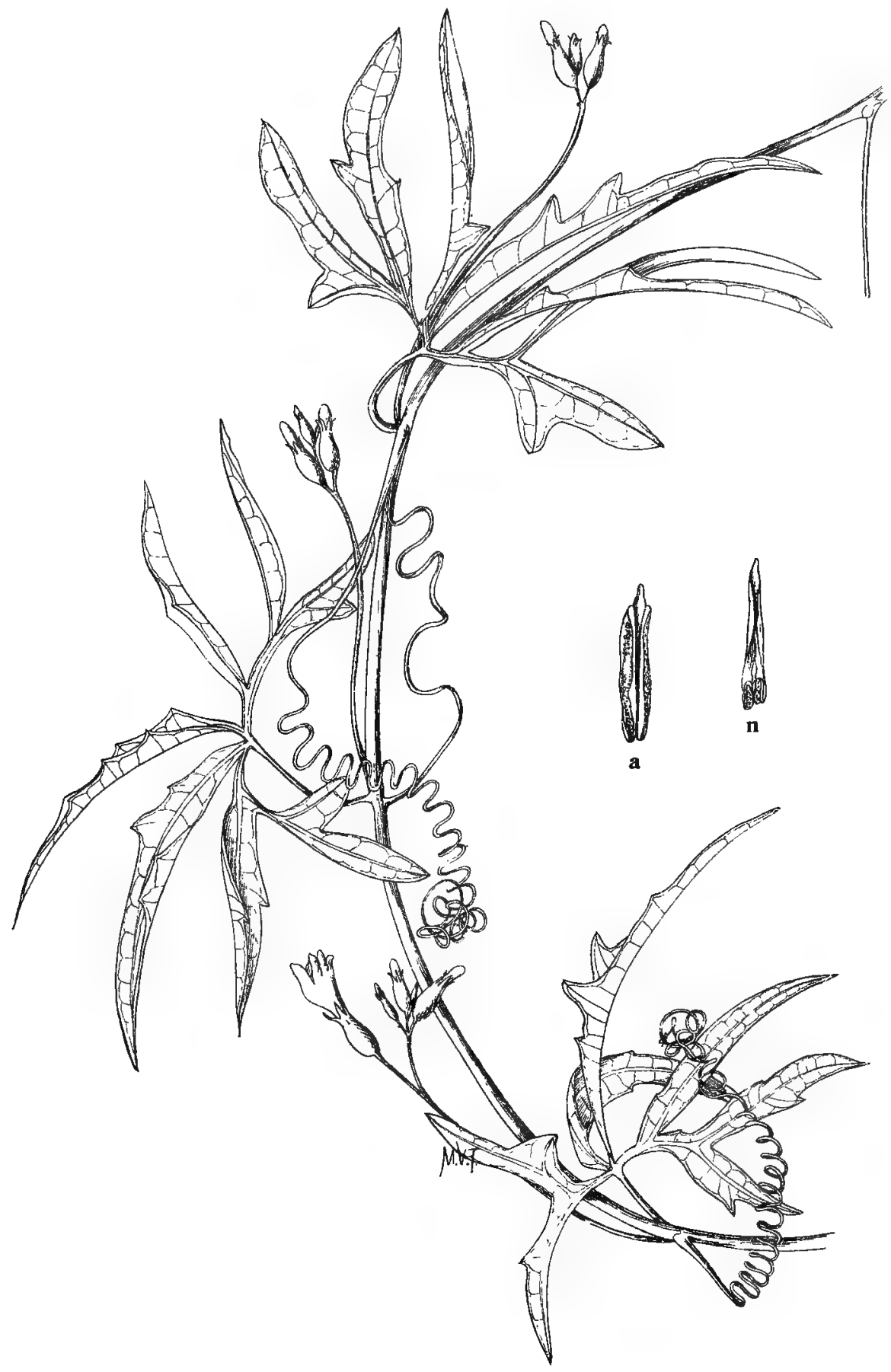



ERnodea littoraits Sw. Common in the pines on both islands (sometimes near the shore). Flowers red or white. New Providence, Jan.; Rose Island, N.P., Feb.; Nicol's Town, March (IO2, 264).

Spermacoce tenuior Lam. In the pines, N.P., Feb. (3rg). Same as Eggers 444I.

Galium Hispidulum Mx. Conch Sound, April (523). Plants glabrous, in leaf only.

\section{Cucurbitace ex}

\section{Anguria Keithii sp. nov.}

Stem climbing, glabrescent, somewhat sulcate; leaves deeply divided with seven narrowly elliptical segments, $4-6.5 \mathrm{~cm}$. long, $.5^{-1} \mathrm{~cm}$. wide, outside segments lobed near the base; central segments the narrowest, apex mucronate, tapering at base, margin entire above but the three or five central segments with a few large mucronate teeth (one to five on each side); petiole $.5^{-2} \mathrm{~cm}$.; leaves rather thin, somewhat punctate beneath; tendrils simple, much longer than the leaves; inflorescence racemose, the 3-6 flowers approximate at the top of the peduncle; peduncle about $8 \mathrm{~cm}$. long, longer than the leaves, pedicels $5^{-9} \mathrm{~mm}$. long; staminate flowers, calyx tubular-campanulate, constricted at the throat, tube 5-7 mm. long, lobes 5, 2-3 $\mathrm{mm}$. long, lanceolate, acuminate; petals orange, elliptical, about I cm. in length, obtuse or shortly mucronate; stamens 2, included, anthers inserted about the middle of the tube, sessile, lanceolate, acuminate or acute, about $6 \mathrm{~mm}$. in length, replicate below about one-third of the way; pistillate flowers and fruit not seen $\left(55^{6}\right)$.

Collected at Conch Sound, Andros, May 8. Comes nearest to A. pedata Jacq., but differs in having leaves 7-cleft, segments narrower, margin more deeply toothed, and leaves thinner; flowers fewer, sepals longer and acuminate.

Named for Mr. Alexander Keith, of Edinburgh, on whose sisal plantation the plant was collected.

Plate r8. Anguria Keithii. Portion of vine, $\times \frac{6}{7}$; $a$, stamen, front view; $n$, stamen, rear view.

Trianosperma Racemosa (Griseb.). T. \& G. Conch Sound, March (4I9). Same as Wright 1243 . 


\section{GOODENIACE E}

Scavola Plumieri (L.) Vahl. Common on the sandy beaches on both islands. South Beach, N.P., Jan. (85).

\section{Composite}

Vernonia BaHamensis Griseb. Common in the pines on both islands. Nassau, Jan. (IOI). Same as Eggers 4I87 and Brace II8. Ageratum conyzoides L. Nassau, Jan. (22).

EUPatorium ageratifolium DC. Nassau, Jan. (i76). Same as Wright $28 \circ 3$.

\section{Eupatorium Bahamense sp. nov.}

Shrubby, branching, branches cylindrical, striate, tips pubescent, somewhat rusty; leaves opposite, petioles 3-10 $\mathrm{mm}$. in length, lanceolate or ovate-lanceolate, $2-4.5 \mathrm{~cm}$. long, $.75^{-2} \mathrm{~cm}$. wide, base cuneate, apex obtuse, margin entire or slightly repand, triply nerved (in some young leaves obscurely so), the lateral nerves usually starting $2-5 \mathrm{~mm}$. above the base, glabrous above, glabrate and densely dotted with glands beneath, glands mostly black; corymbs numerous, trichotomous, peduncles with a few scattered glands; heads shortly pedicellate, often in pairs, pedicels $2-6 \mathrm{~mm}$. in length, ten- to thirteenflowered; flowers blue, receptacle cylindrical, flat on top; involucre cylindrical, 8-1o $\mathrm{mm}$. long, about $2 \mathrm{~mm}$. broad, scales imbricate in about four rows, innermost linear-lanceolate, about $6 \mathrm{~mm}$. in length, outer lanceolate or oblong-lanceolate, apex rounded, sometimes somewhat spatulate, the outer somewhat thickened at the top and darker, mostly three-striate, inner scales sometimes slightly toothed near the base; corolla light blue, clavate, $3^{-4} \mathrm{~mm}$. long, teeth less. than I mm.; pappus white, spreading, about as long as the corolla; achenia black, tapering at the base, three-, four- or five-angled, mostly three, with the other angles obsolete, angles scabrous (359).

Collected in the coppet at Nicol's Town, March I7. Not uncommon. Same as Eggers 4424 and Brace 225.

Related to $E$. conyzoides Vahl, but differs in having the leaves and branches less divaricate, leaves obtuse, involucral scales tapering at the apex, heads fewer flowered, and achenia often 3-4-angled.

Plate I9. Eupatorium Bahamense. Portion of plant, $\times \frac{5}{8} ; u$, head of flowers.

Eupatorium CAPILlfFolium (Lam.) Small. (E. foniculaceum Willd.) Hog Island, N.P., Feb. (252). 


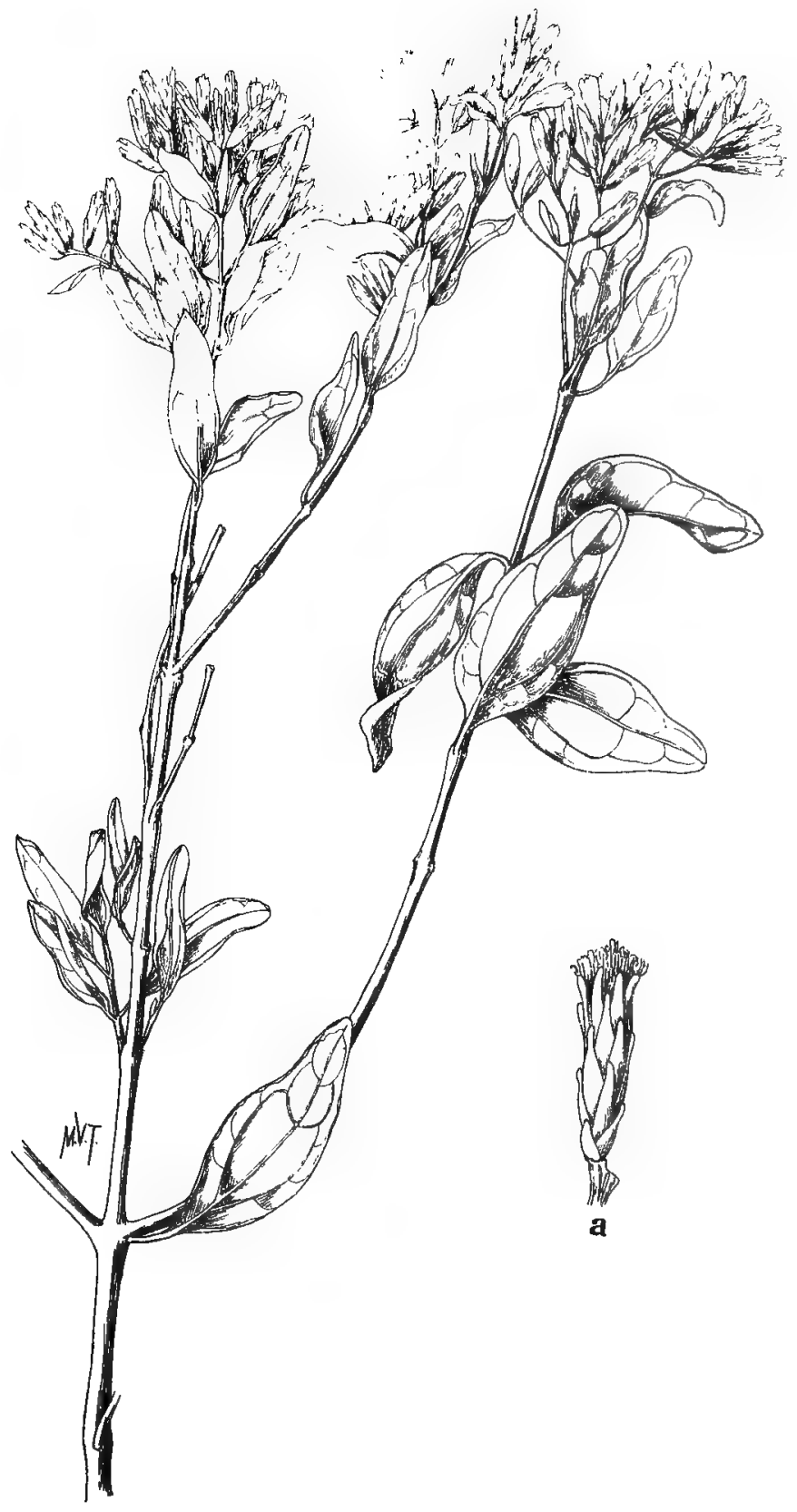

EUPATORIUM BAHAMENSE 

Eupatorium Odoratum L. Nassau, Jan. (6). Same as Wright 295.

Eupatorium villosum Sw. Common and variable. Nassau, Nicol's Town, March, Conch Sound, April (307, 340, 563). No. 307 from Nassau, and 563 from Conch Sound are almost entirely glabrous forms.

Willughberya scandens (L.) Kuntze. (Mikania Orinocensis H.B.K.) Not uncommon in wet places Hog Island, Feb.; Conch Sound, May (245). Same as Wright 3600.

Aster ExILIs Ell. In damp places. Hog Island, N.P., Feb.; Conch Sound, April; Fresh Creek, June (246, 650).

BACCHARIS DIOICA Vahl. "Broom-bush." Common near the shore. Nassau, Jan. (68).

ERIGERON QUERCIFOLIUM Lam. In the pines. New Providence, Feb.; Nicol's Town, March $(324,360)$.

Pluchea fcetida (L.) B.S.P. Damp ground in the pines. Red Bays, April (498). Same as Eggers 4IO3.

Pluchea CAMphorata DC. Banana holes in the pines. N.P., Feb. $(3 \mathrm{I} 7)$.

Pluchea odorata (L.) Cass. "Cough-bush." New Providence, Feb.; Nicol's Town, March (283).

Parthenium Hysterophorus L. Nassau, Jan. (I).

Iva Cheiranthifolia Kth. New Providence, Feb. (3II). Same as Eggers 4286.

Iva ImBricata Walt. Common on sandy shores. Deep Creek, July (7I6).

Ambrosia hispida Pursh. "Bay lavender," "sweet bay." Common on sandy beaches of both islands. Nassau, Jan.; Mastic Point, May (62).

IsocaRPHA OPPOSITIFolia R. Br. "Boston catnip." Deep Creek, June (68I). Determined at Kew by Dr. Britton.

BorRICHIA ARBORESCENS DC. Common on both islands. Glabrate and canescent forms found growing together in several localities. Nassau, Jan. (90). Canescent form the same as Eggers r609, the glabrous the same as Wright 2899.

Amellus Aspera (Jacq.) Kuntze. (Melanthera deltoidea Rich.) Common on both islands. Nassau, Jan.; Red Bays, April (58, 5०3). 
Salmea petrobiomes Griseb. Nassau, Feb. Common along shore $(3 \circ 3)$.

Bidens leucantha Willd. "Shepherd's needle." Nassau, Jan. (36).

Tridax PRocumbens L. Nassau, Jan. (25).

Flaveria tinearis Lag. Red Bays, April (462). Same as Wright 2859 .

Porophyllum ruderale Cass. Lisbon Creek, Andros, June (675).

Pectis Linifolia L. "Tea-blinkin." Nassau, Jan. (200).

Neurolena lobata (L.) R. Br. Red Bays, April (486).

Erechthites hieracifolia (L.) Raf. Red Bays, April (504).

Emilia sonchifolia (L.) DC. Nassau, Jan. (3, 5).

Anastraphia Northropiana Greenman. "Candlewood." Fresh Creek, June (743). Differs from the following species in having the "leaves mostly entire, scales of the involucre more numerous and strongly revolute." Named at Gray herbarium by Mr. J. M. Greenman, I897. Same as Combs no. 52x from Cuba, I895.

Anastraphia pauciflosculosa Wright. "Candlewood." Lisbon Creek, June. Same as Eggers 3866. Determined at Kew by Dr. Britton (639).

Chaptalia Albicans (DC.). Conch Sound, March (400). Same as Wright 2873 .

Sonchus oleraceus L. Nassau, Jan. (48).

\section{Relations of the BaHama Flora}

Professor Hitchcock has treated this subject very fully in his "Report on the Plants collected in the Bahamas, Jamaica, and Grand Cayman." It is only taken up here because the exploration of Andros has furnished additional data. In this connection it may be well to describe briefly the character and position of the Bahama Islands in relation to the Greater Antilles and North and South America. "The Bahamas naturally divide themselves, first, into sunken banks like the Navidad, Silver, and Mouchoir banks; next, islands occupying the whole or nearly the whole summit of the banks from which they rise, like Watlings, Rum Cay, Conception, Samana, Mariguana, the Plana Cays, Inagua, Little Inagua, and the atoll of Hogsty; then banks having the semblance of atolls, like the Crooked Island and Caicos 
banks, which are fringed by low islands forming a crescent with an open lagoon or flat between its horns; next, Salt Cay Bank, which from its structure holds a position intermediate between the group of sunken banks like the Navidad and that resembling Caicos Bank, and finally, such composite banks as the Little Bahama and Great Bahama banks with the characteristics of a combination of banks resembling all the others." 1

The Little Bahama Bank, lying in $26^{\circ}$ to $27^{\circ}$ north latitude, is the most northerly. From it rise the islands of Great Bahama and Abaco with a number of small cays. The Little Bahama Bank is separated from the Great Bahama Bank lylng south of it by the Northeast and Northwest Providence channels, which are from twenty to thirty miles wide and have a depth of from 500 to 2000 fathoms.

"The Great Bahama Bank is irregularly V-shaped and has an extent of four hundred miles from northwest to southeast and is about two hundred and fifty miles in its greatest width." 1

The water on the bank is usually only three or four fathoms deep, but it is indented on the north by a tongue of the ocean which extends nearly two thirds across it and has a depth of from 700 to I200 fathoms. Along the western edge of this tongue of ocean lies Andros, while New Providence is on the eastern side, twenty-five miles or more distant. On the eastern border of Great Bahama Bank lie the long narrow islands known as Eleuthera, Cat Island, Exuma, and Long Island, the first two being separated from the third by another indentation in the bank from the south known as Exuma Sound. 'To the southeast of Cat Island are the isolated islands of Rum Cay and San Salvador, or Watlings Island, while east of the southern end of the Great Bahama Bank is the much smaller bank on which are situated Crooked, Acklin, and Fortune islands. Still farther southeast lie Mariguana, the Caicos Bank and Islands and Turks Islands, while the entirely isolated island of Inagua is off to the west. Inagua lies in a latitude of about $2 \mathrm{r}^{\circ}$ and is the most southerly of the Bahamas. It is about fifty miles from the east end of Cuba and about sixty miles north of the western end of Haiti. From both islands it is separated by water over 1500 fathoms in depth.

1 "A Reconnoissance of the Bahamas and of the Elevated Reefs of Cuba in the Steam Yacht Wild Duck, January to April, I893," Alexander Agassiz. 
The Little Bahama Bank is separated from Florida by a distance of fifty miles and a depth of less than $45^{\circ}$ fathoms of water. The Great Bahama Bank extends west and northwest of Andros for a distance of from fifty to seventy miles. At its western edge it is only forty miles distant from Florida, and the channel is about $45^{\circ}$ to 500 fathoms deep.

The Great Bahama Bank is separated from Cuba on the south by the Old Bahama Channel, about 300 fathoms in depth, the narrowest part of which is only about twelve miles. Beyond this point the water deepens rapidly to 500 and I000 fathoms.

The following is quoted from Professor Hitchcock's admirable account: "If, from any cause, the depth of the water of the ocean should be lessened by Ioo fathoms, there would be exposed the Little Bahama and Great Bahama banks and several of the smaller banks to the southeast. The Bahamas would be separated from the surrounding islands and from Florida and the important channels would still occupy the same places. If reduced by 300 fathoms, the Great Bahama Bank would be united with Cuba. If the water were 500 fathoms shallower than at present, the Little and Great Bahama banks would be united with Florida and some of the Windward Islands would be connected. It is not, however, until a layer of water Iooo fathoms deep is removed that important changes would occur. Jamaica would be united with Honduras, Cuba with Florida and also with South America through the Windward Islands. There would be a narrow channel between Cuba and Yucatan, between Jamaica and Haiti, and a wide and deep channel between Jamaica and Cuba. Watlings, the Acklin Island group, and Inagua would still be isolated and the distances between them and the neighboring land would not be materially diminished. . . . The Greater Antilles are of ancient formation and may have been connected with Mexico and Central America at some remote period. But the Bahamas, the Windward Islands, and the southern extremity of Florida are of recent origin."

Professor Hitchcock thinks, however, as does the writer, that the ordinary methods of dissemination are sufficient to account for the Bahaman flora and that the theory of an ancient land connection is not necessary.

The following table shows the distribution of the plants collected by us on New Providence and Andros and bears out the conclusion 
arrived at by Hitchcock and others that the bulk of the Bahaman plants have come from the south.

Although Andros is very nearly as close to Florida as it is to Cuba, its plants are most closely allied with those of Cuba, comparatively few species, apparently, having come from the north. Our exploration of Andros, however, has shown that this northern contingent is considerably larger than was supposed, a distinct colony of northern plants having found a foothold on the west side of Andros. Many of these have never been reported from either Cuba or any of the other islands of the group.

It was to be expected that the majority of the Bahaman plants would have a southern origin, on account of the greater similarity of the climate and because the prevailing winds and currents are from that direction. There are occasionally heavy "northers" during the winter, when the wind blows hard from the northwest for a number of days at a time. The velocity of the Gulf Stream as it flows through the Florida Straits tends to prevent seeds being brought from the north by water.

In compiling the table found below, giving the distribution of the plants collected by us, the following volumes have been the principal ones consulted: Grisebach's Flora of the British West Indies, Grisebach's Catalogus Plantarum Cubensium, Plants collected in the Bahamas by Hitchcock, Plants collected in the District of Cienfuegos, Cuba, by Robert Combs, I895; Jamaica, List of Fawcett; Flora of St. Croix and the Virgin Islands, Eggers; Chapman's Flora of the Southern United States, and other works on the North American flora. 


\section{FLORA OF NEW PROVIDENCE AND ANDROS}

Tabulated Distribution

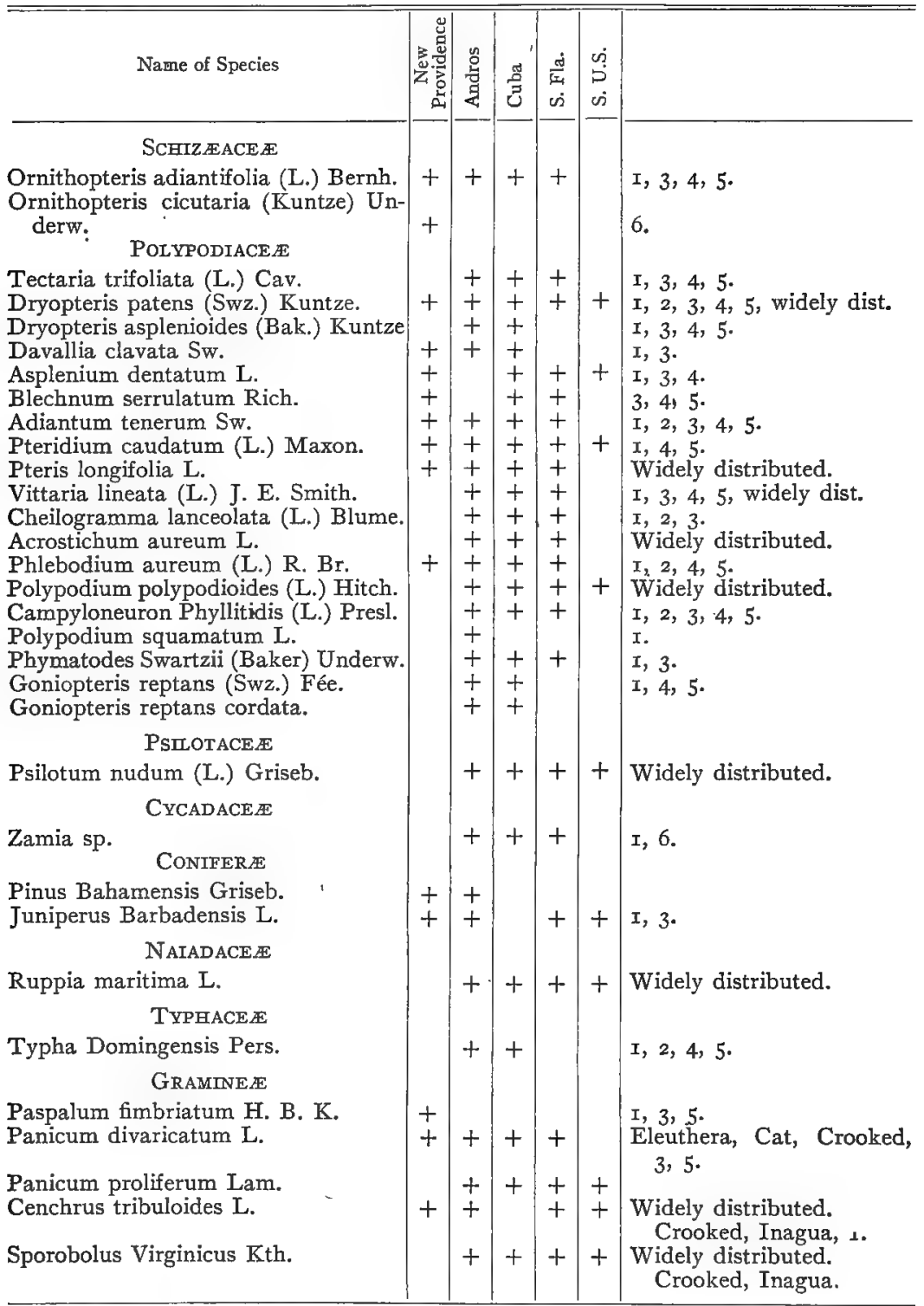

NotE. - I, Jamaica; 2, Virgin Islands; 3, Windward Islands; 4, Mexico and Central America; 5, South America; 6, Haiti. When a plant is reported from all the preceding localities (or all but Haiti) and also as being found in the Eastern Hemisphere, it is marked "Widely distributed." 


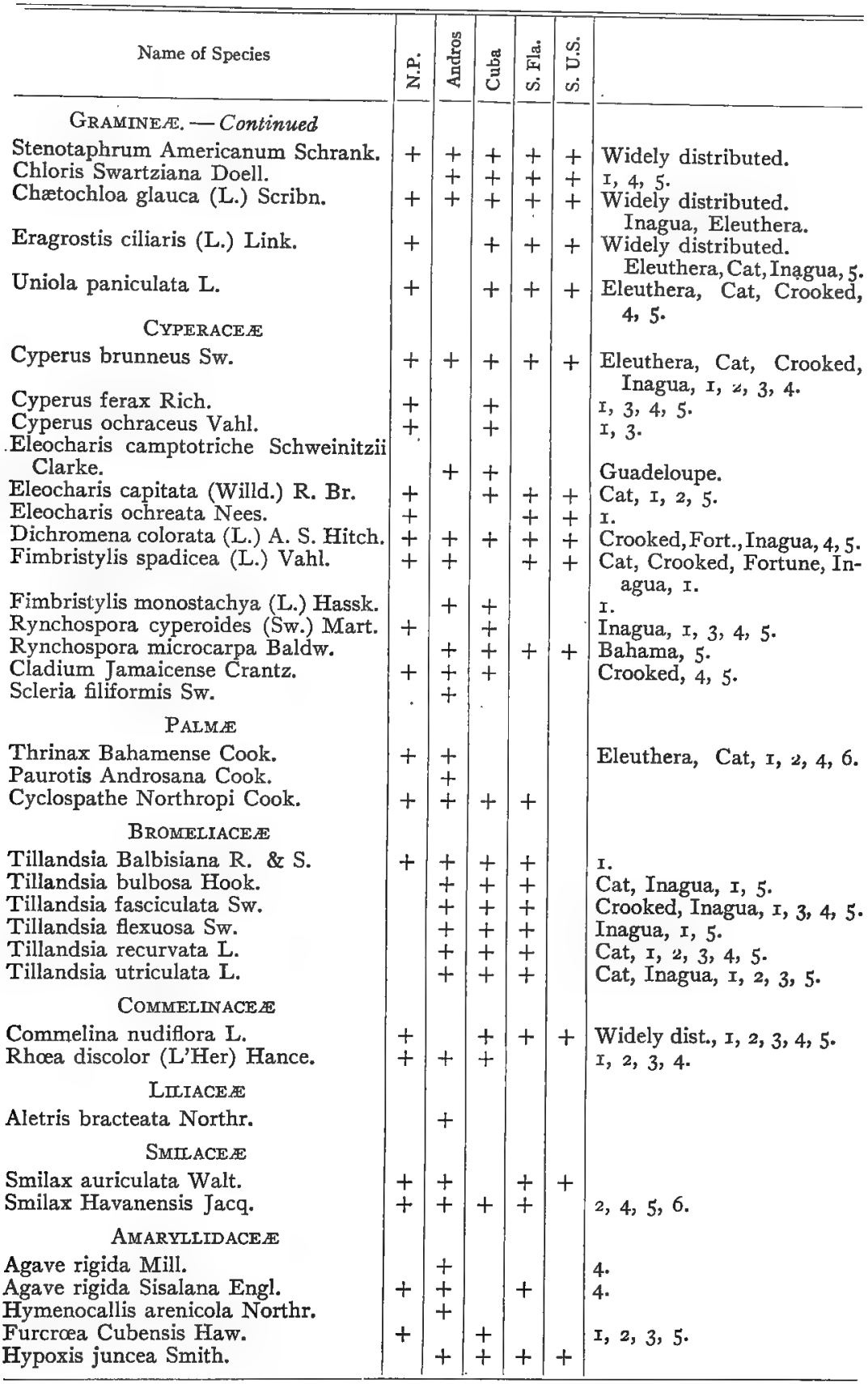




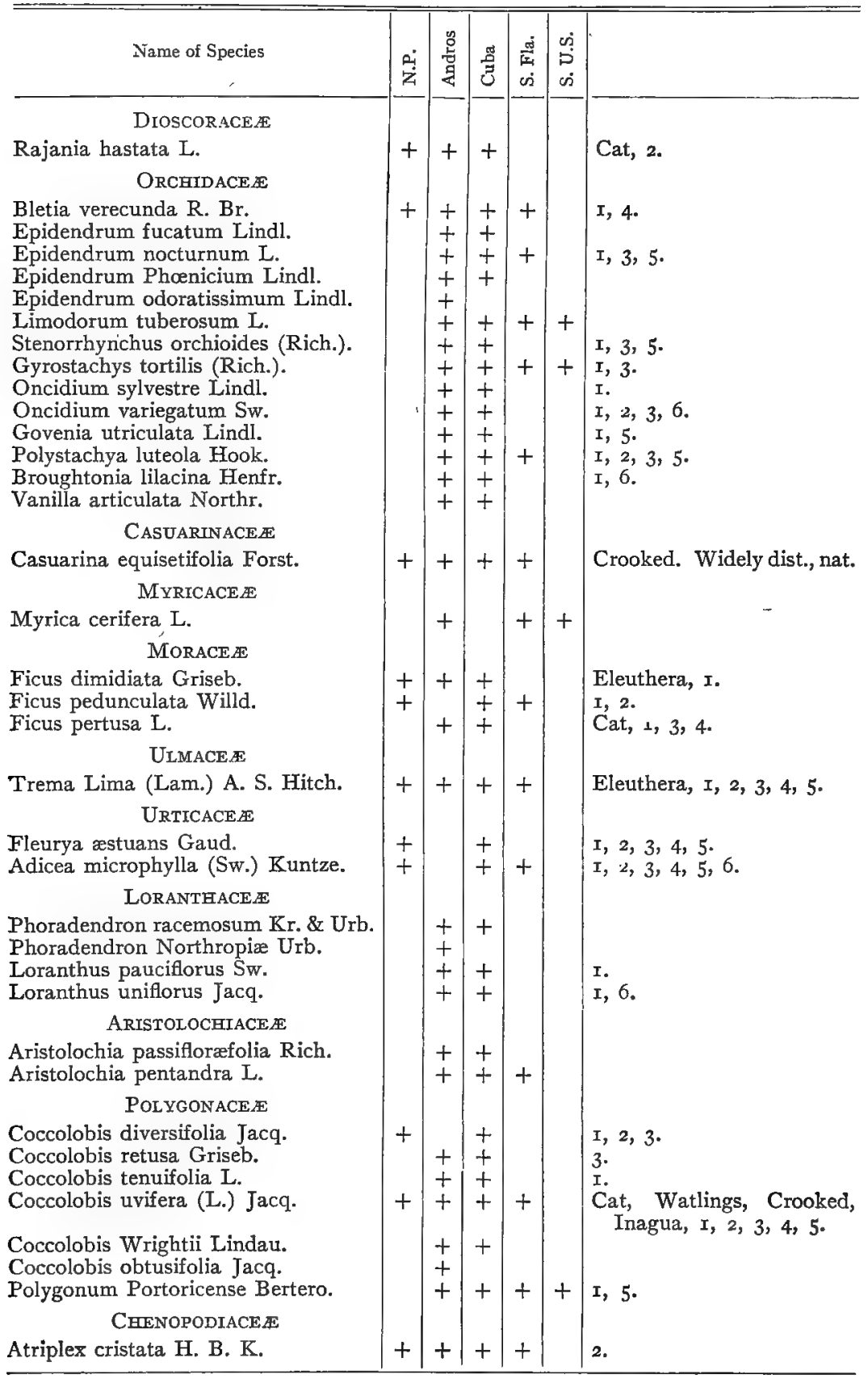




\begin{tabular}{|c|c|c|c|c|c|c|}
\hline Name of Species & $\stackrel{0}{\circ}$ & 旁 & ปే & $\begin{array}{l}\frac{\infty}{\omega} \\
\dot{n} \\
\dot{n}\end{array}$ & $\begin{array}{l}\dot{m} \\
\dot{D} \\
\dot{m} \\
\dot{m}\end{array}$ & \\
\hline $\begin{array}{l}\text { CHENopodiacese. - Continued } \\
\text { Salicornia ambigua Michx. } \\
\text { Salicornia Bigelovii Torr. } \\
\text { Dondia fruticosa (Forsk.). } \\
\text { Dondia linearis (Moq.) Millsp. }\end{array}$ & + & $\begin{array}{l}+ \\
+ \\
+\end{array}$ & + & $\begin{array}{l}+ \\
+ \\
+\end{array}$ & $\begin{array}{l}+ \\
+\end{array}$ & Crooked. \\
\hline \begin{tabular}{l}
\multicolumn{1}{c|}{ AMARANTACE $x$} \\
Alternanthera muscoides Sw. \\
Alternanthera paronychioides St. Hil. \\
Lithophila vermicularis (L.) Uline. \\
Iresine paniculata (L.) Kuntze.
\end{tabular} & $\begin{array}{l}+ \\
+ \\
+\end{array}$ & $\begin{array}{l}+ \\
+\end{array}$ & $\begin{array}{l}+ \\
+\end{array}$ & $\begin{array}{l}+ \\
+\end{array}$ & $\begin{array}{l}+ \\
+\end{array}$ & $\begin{array}{l}\text { Inagua, } 3 . \\
\text { Eleuthera. Widely dist. } \\
\text { Eleuth., Cat, Watlings } \\
\text { Widely distributed. }\end{array}$ \\
\hline $\begin{array}{c}\text { BATIDE } A \\
\text { Batis maritima L. } \\
\text { PHYTOLACCACE } \&\end{array}$ & & + & + & + & + & Inagua, $I, 2,3,5$. \\
\hline $\begin{array}{l}\text { Rivina humilis glabra } \mathrm{L} . \\
\text { Phytolacca octandra L. } \\
\text { NYCTAGINACEx }\end{array}$ & + & $\begin{array}{l}+ \\
+\end{array}$ & $\begin{array}{l}+ \\
+\end{array}$ & + & + & $\begin{array}{l}I, 2,3,4,5, \text { Cat. } \\
I, 3,4,5 .\end{array}$ \\
\hline $\begin{array}{l}\text { Mirabilis Jalapa L. } \\
\text { Boerhaavia erecta L. } \\
\text { Boerhaavia paniculata Rich. } \\
\text { Boerhaavia scandens L. } \\
\text { Pisonia aculeata L. } \\
\text { Pisonia obtusata Swz. } \\
\text { Pisonia rotundata Griseb. }\end{array}$ & $\begin{array}{l}+ \\
+ \\
+ \\
+ \\
+ \\
+\end{array}$ & $\begin{array}{l}+ \\
+ \\
+ \\
+\end{array}$ & $\begin{array}{l}+ \\
+ \\
+ \\
+ \\
+ \\
+ \\
+\end{array}$ & $\begin{array}{l}+ \\
+ \\
+\end{array}$ & $\begin{array}{l}+ \\
+\end{array}$ & $\begin{array}{l}\text { Fortune, I, 3, 4, 5. } \\
\text { I, 3, 4. } \\
\text { Eleuthera, I, 2, 3, 4. } \\
\text { Eleuthera, i, 4, 5. } \\
\text { I, 3, 4, 5. } \\
\text { Crooked, I, 3, 5. }\end{array}$ \\
\hline $\begin{array}{c}\text { AIZOACE } \mathbb{E} \\
\text { Sesuvium portulacastrum L. }\end{array}$ & + & + & + & + & + & $\begin{array}{l}\text { Widely distributed. Eleu- } \\
\text { thera, Cat, Crooked, } \\
\text { Fortune. }\end{array}$ \\
\hline $\begin{array}{l}\text { PORTULACACE.⿻ } \\
\text { Portulaca oleracea L. }\end{array}$ & + & $\begin{array}{l}+ \\
+\end{array}$ & + & + & + & $\begin{array}{l}\text { Eleuthera, Inagua. Widely } \\
\text { distributed. }\end{array}$ \\
\hline $\begin{array}{l}\text { Portulaca halimoides L. } \\
\text { ANONACEAE }\end{array}$ & & + & & + & & $I, 2,3$ \\
\hline $\begin{array}{l}\text { Anona palustris L. } \\
\text { RANUNCULACE正 }\end{array}$ & & + & + & & & $I, 2,3,5$. \\
\hline $\begin{array}{l}\text { Clematis dioica } \mathrm{L} . \\
\text { LAURACE } \not T\end{array}$ & & + & + & & & I, 3, 4, 5. \\
\hline $\begin{array}{l}\text { Nectandra sanguinea Rottb. } \\
\text { Cassytha filiformis L. }\end{array}$ & $\begin{array}{l}+ \\
+\end{array}$ & $\begin{array}{l}+ \\
+\end{array}$ & + & + & & $\begin{array}{l}\text { I, 3, 4, 5. } \\
\text { Eleuthera, Cat, } 1,2,3,4,5 \text {. }\end{array}$ \\
\hline $\begin{array}{l}\text { PaPaverace } x \\
\text { Argemone Mexicana L. }\end{array}$ & + & & + & + & + & $\begin{array}{l}\text { Eleuth., Crooked, Fortune, } \\
\text { Inagua. Widely dist. }\end{array}$ \\
\hline $\begin{array}{l}\text { CRUCIFER } x \\
\text { Brassica arvensis (L.) B. S. P. } \\
\text { Lepidium Virginicum L. }\end{array}$ & $\begin{array}{l}+ \\
+\end{array}$ & & + & + & $\begin{array}{l}+ \\
+\end{array}$ & $\begin{array}{l}\text { Int. from Europe, } 2 \text {. } \\
\text { Eleuthera, Cat, Inagua, } \\
\quad 1,2,3,4 \text {. }\end{array}$ \\
\hline $\begin{array}{l}\text { Cakile æqualis L'Her. } \\
\text { CAPPARIDACE } \leftleftarrows\end{array}$ & + & + & + & + & + & $I, 2,3$ \\
\hline Pedicellaria pentaphylia (L.) Schrank. & + & + & + & + & + & Eleuthera. Widely dist. \\
\hline
\end{tabular}




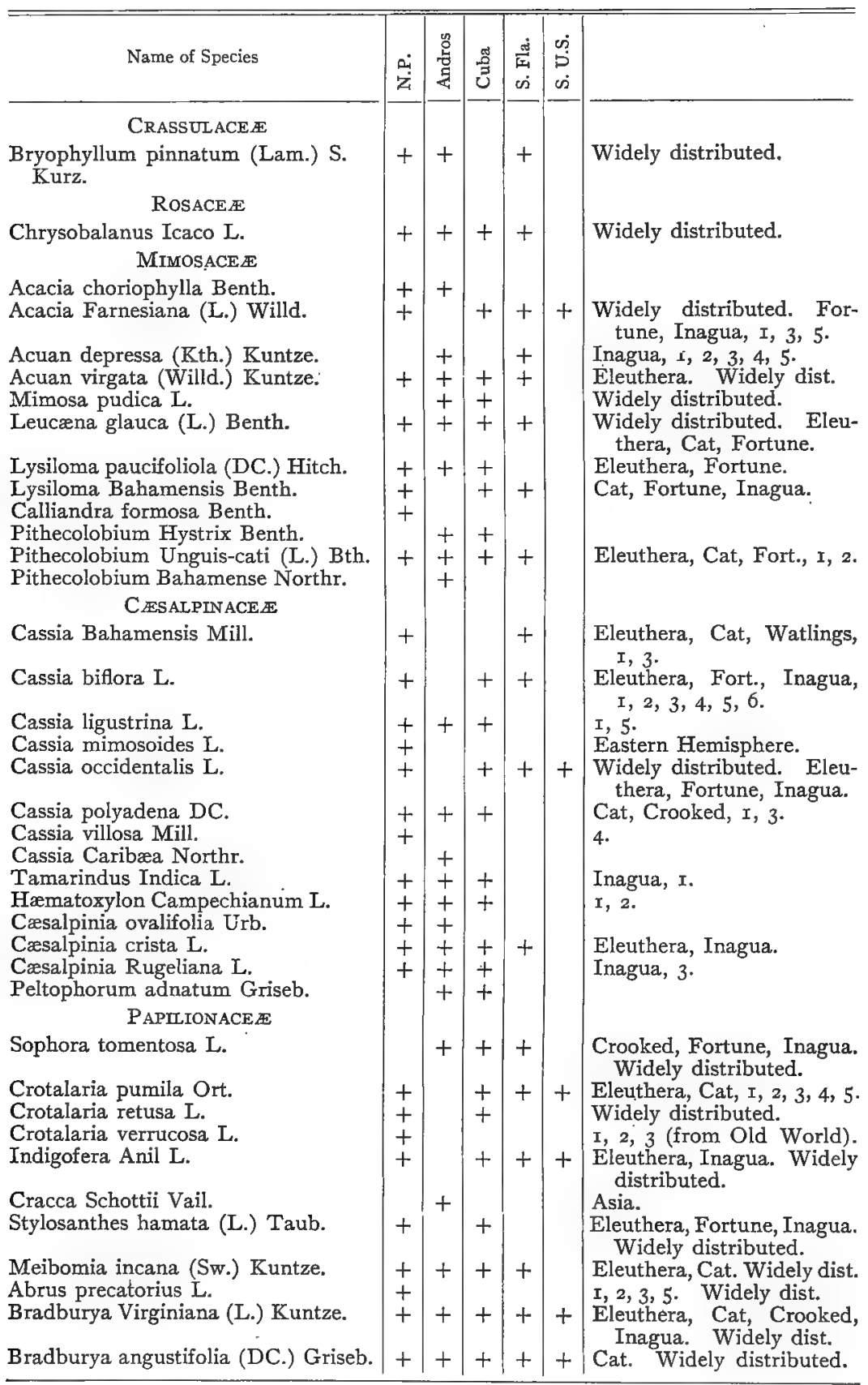




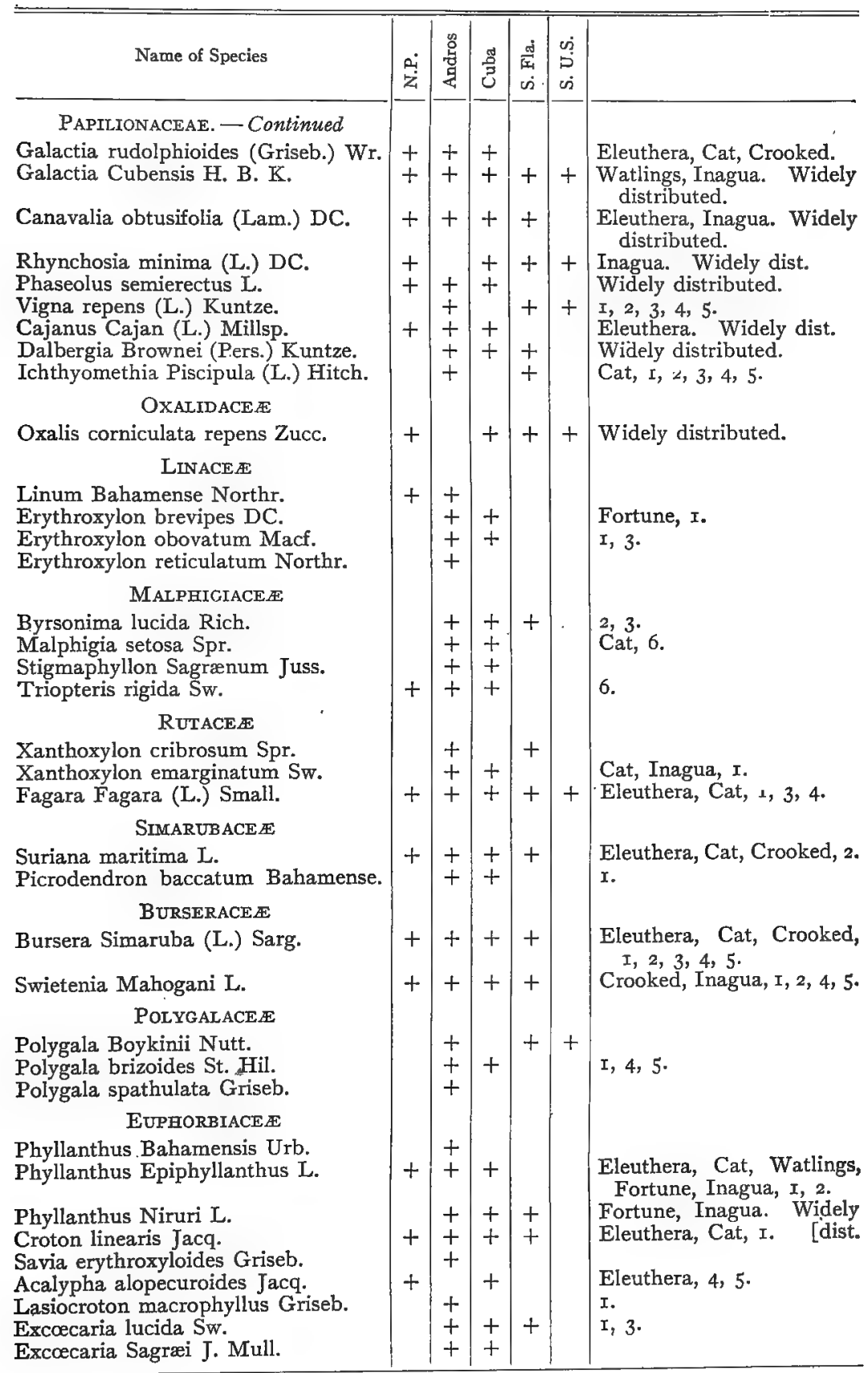




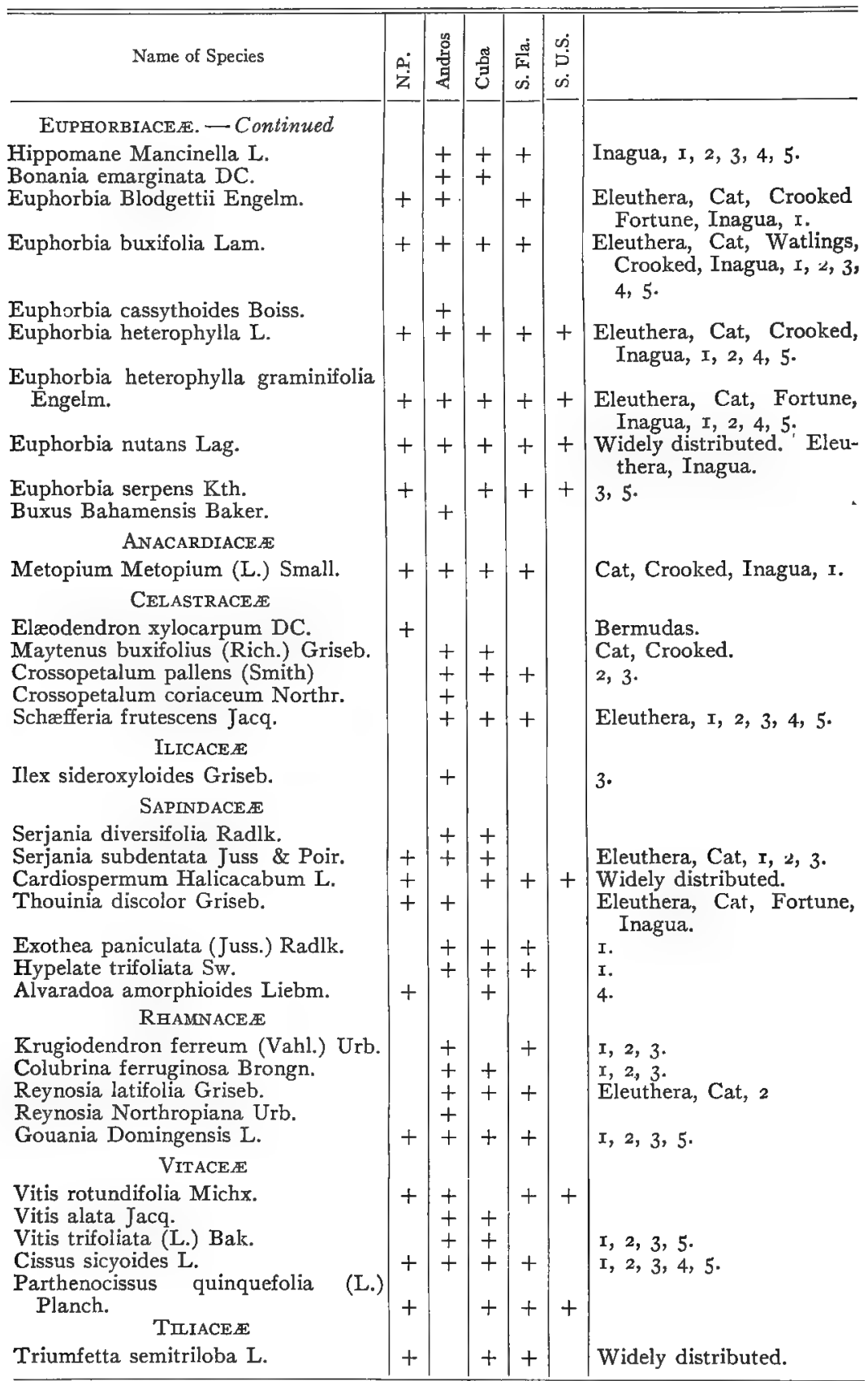




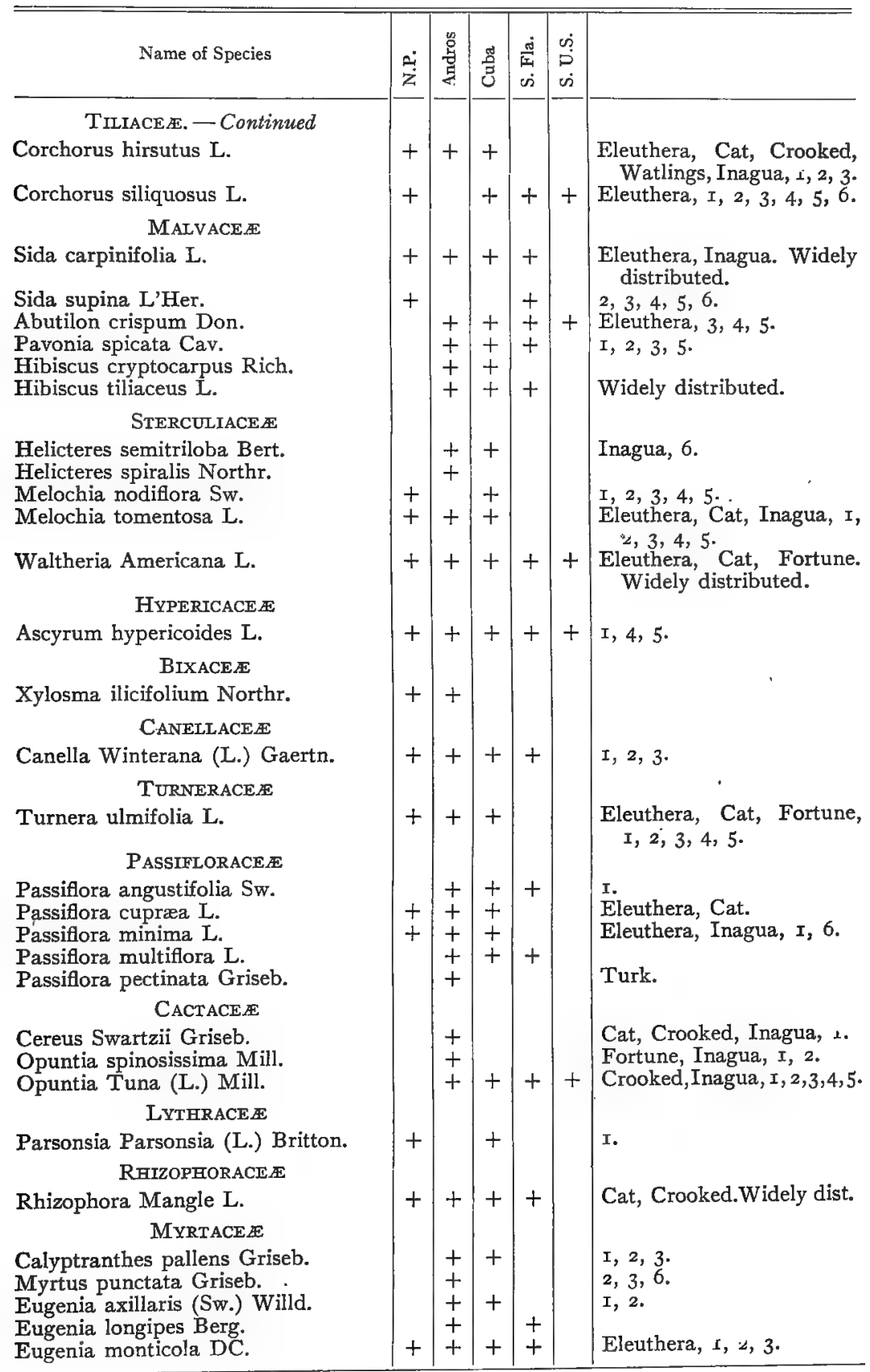




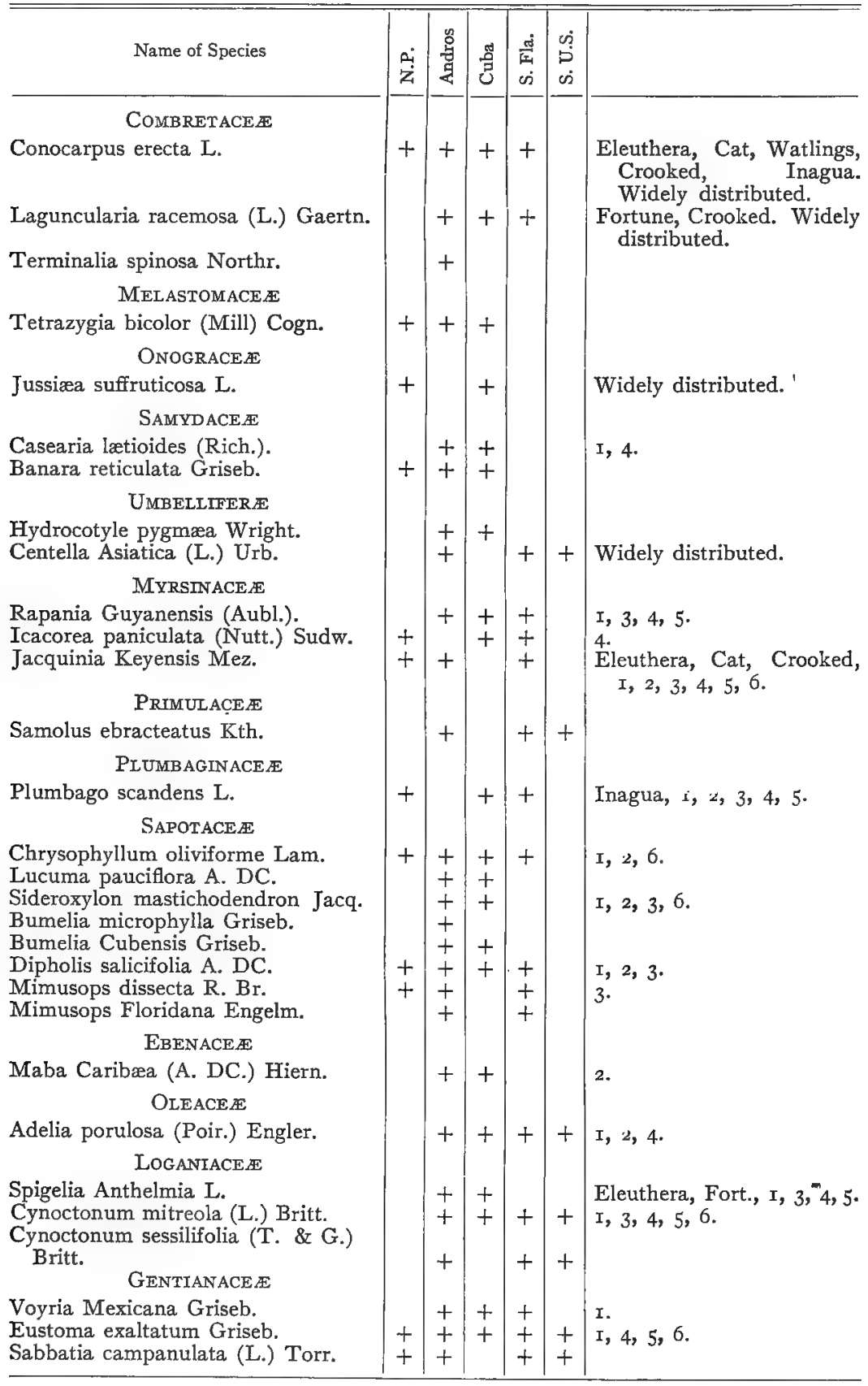




\begin{tabular}{|c|c|c|c|c|c|c|}
\hline Name of Species & 莫 & \begin{tabular}{|l|} 
总 \\
总 \\
量
\end{tabular} & 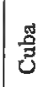 & 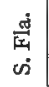 & 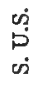 & \\
\hline APOCYNACEA & & & & & & \\
\hline Vinca rosea L. & + & & + & + & & Widely distributed. \\
\hline Plumiera obtusa L. & & + & + & & & Cat, I, 2, Fortune, Inagua. \\
\hline Echites Andrewsii Chapm. & + & + & + & + & & Eleuthera, Cat, Watlings, \\
\hline Echites biflora Jacq. & & + & & & & $3,5$. \\
\hline Echites Sagræi A. DC. & + & + & + & + & & \\
\hline Echites umbellata Jacq. & + & + & + & + & & $\begin{array}{l}\text { Eleuthera, Cat, Fortune, } \\
\text { Crooked, Inagua, I, 4,6. }\end{array}$ \\
\hline ASCLEPIADACE $A E$ & & & & & & \\
\hline Asclepias Curassavica L. & + & & + & + & & Widely distributed. \\
\hline $\begin{array}{l}\text { Metastelma Bahamense Griseb. } \\
\text { Metastelma barbatum Northr. }\end{array}$ & & $\begin{array}{l}+ \\
+\end{array}$ & + & & & \\
\hline Metastelma palustre Schltr. & + & $\stackrel{T}{+}$ & & + & + & Fortune, Inagua, 2. \\
\hline CONVOLVULACE & & & & & & \\
\hline Ipomoea cathartica Poir. & + & & + & & & $I, 3,4,5:$ \\
\hline Ipomoea coccinea L. & + & & & + & + & Widely distributed. \\
\hline Ipomoea commutata R. \& S. & + & + & + & $\begin{array}{l}+ \\
+ \\
+\end{array}$ & + & I, 5. \\
\hline Ipomœe heptaphylla Griseb. & & + & + & & & 4,5 \\
\hline Ipomœe Jamaicensis Don. & + & + & + & & & Eleuthera, I, 4, 5 . \\
\hline Ipomoea grandiflora Lam. & + & + & & & & \\
\hline Ipomcea Pes-capræ (L.) Sweet. & + & + & + & + & + & $\begin{array}{l}\text { Fortune, Inagua. Widely } \\
\text { distributed. }\end{array}$ \\
\hline Ipomoea repanda Jacq. & + & + & + & & & Eleuthera, Cat, Fortune, 3 . \\
\hline Ipomoea sinuata Ort. & + & + & + & + & + & Eleuthera. Widely dist. \\
\hline Ipomcea triloba $\mathrm{L}$. & + & + & + & + & 1 & $\begin{array}{l}\text { Eleuthera, Fortune, Inagua, } \\
\text { Crooked. Widely dist. }\end{array}$ \\
\hline $\begin{array}{l}\text { Jacquemontia Jamaicensis (Jacq.) } \\
\text { Hall. }\end{array}$ & + & + & + & & & $\begin{array}{l}\text { Eleuthera, Cat, Crooked, } \\
\text { Inagua, }, 6 .\end{array}$ \\
\hline Jacquemontia verticillata (L.) Urb. & & + & + & & & I, $3,5$. \\
\hline Ẹvolvulus arbuscula Poir. & & + & + & & & $\begin{array}{l}\text { Eleuthera, Fortune, Inagua, } \\
\text { I, } 6 .\end{array}$ \\
\hline Dichondra repens Forst. & + & & + & + & + & Widely distributed. \\
\hline Cuscutace $z$ & & & & & & \\
\hline Cuscuta Americana L. & & + & + & & & Eleuthera, $I, 2,3,4,5$. \\
\hline HYDROPHYLIACEAE & & & & & & \\
\hline Nama Jamaicensis $L$. & + & & t & + & + & $I, 4,6$. \\
\hline BORAGINACE在 & & & & & & \\
\hline $\begin{array}{l}\text { Cordia angustifolia R. \& S. } \\
\text { Cordia lima R. \& S. }\end{array}$ & & + & + & & & \\
\hline Cordia Sebestena L. & + & + & + & + & & Inagua, $i, 3,5$ \\
\hline Bourretia Havanensis (Willd.) Miers. & + & + & + & + & & $\begin{array}{l}\text { Eleuthera, Cat, Crooked, } \\
\text { Fortune, I. }\end{array}$ \\
\hline $\begin{array}{l}\text { Tournefortia gnaphalodes (Jacq.) } \\
\text { R. Br. }\end{array}$ & + & + & + & + & & $\begin{array}{l}\text { Eleuthera, Watlings, In- } \\
\text { agua, } 1,2,3 \text {. }\end{array}$ \\
\hline Tournefortia volubilis $\mathbf{L}$. & + & + & + & + & + & Eleuthera, Inagua, $1,2,3,5$. \\
\hline Heliotropium Curassavicum L. & 1 & + & + & + & & $\begin{array}{l}\text { Cat, Crooked, Inauga. } \\
\text { Widely distributed. }\end{array}$ \\
\hline Heliotropium parviflorum L. & + & & + & + & & Eleuthera, Cat, Inagua, I, \\
\hline Heliotropium nanum Northr. & & + & & & & \\
\hline
\end{tabular}




\section{FLORA OF NEW PROVIDENCE AND ANDROS}

\begin{tabular}{|c|c|c|c|c|c|c|}
\hline Name of Species & $\begin{array}{l}a i \\
z \\
z\end{array}$ & 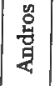 & 骂 & 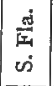 & $\begin{array}{l}\dot{\rho} \\
\dot{5} \\
\dot{\omega}\end{array}$ & \\
\hline \multicolumn{7}{|l|}{ VERBENACEA } \\
\hline Lantana Camara L. & + & + & + & + & + & Watlings, $i, 2,3,4,5,6$ \\
\hline Lantana crocea Jacq. & & + & + & & & Eleuthera, Cat, I, 3, 5, 6 . \\
\hline Lantana involucrata $\mathrm{L}$. & + & + & + & + & & Eleuth., Watlings, Crooked, \\
\hline Lippia canescens Kth. & + & & & & & (al, Litag, $, 2,2,4,30$ \\
\hline Lippia nodiflora (L.) Michx. & + & + & + & + & + & $\begin{array}{l}\text { Eleuthera, Cat, Inagua. } \\
\text { Widely distributed. }\end{array}$ \\
\hline Abena Jamaicensis (L.) A. S. Hitch. & + & & + & + & & $\begin{array}{l}\text { Eleuthera, Cat, Crooked, } \\
\text { Inauga. Widely dist. }\end{array}$ \\
\hline Citharexylum Berterii Spreng. & & + & + & & & \\
\hline Citharexylum lucidum Cham: \& Schl. & & + & + & & & $\mathbf{I}, 3,4,5$ \\
\hline $\begin{array}{l}\text { Duranta repens L. } \\
\text { Petitia Domingensis Jacq. }\end{array}$ & + & $\begin{array}{l}+ \\
+\end{array}$ & + & + & & $\begin{array}{l}\text { Eleuthera, } i, 2,3,4,5 . \\
\text { Grand Cayman, } r, 6 .\end{array}$ \\
\hline Vitex ilicifolia Rich. & & + & + & & & \\
\hline \multicolumn{7}{|l|}{$\begin{array}{l}\text { Avicennia nitida Jacq. } \\
\text { LABIATE }\end{array}$} \\
\hline Micromeria Brownei Benth. & & + & & + & & $I, 5$ \\
\hline $\begin{array}{l}\text { Salvia occidentalis Sw. } \\
\text { Salvia serotina L. }\end{array}$ & $\begin{array}{l}+ \\
+\end{array}$ & & $\begin{array}{l}+ \\
+\end{array}$ & $\dot{t}$ & & El, 3, 4, 5. Cat, Watlings, \\
\hline Leonurus Sibiricus L. & + & & + & + & + & Widely distributed. \\
\hline Leonotis nepetæfolia (L.) R. Br. & + & & + & + & + & $\begin{array}{l}\text { Eleuthera, Inagua. Widely } \\
\text { distributed. }\end{array}$ \\
\hline $\begin{array}{l}\text { Teucrium Cubense L. } \\
\text { Mesosphærum pectinatum (Poit.) }\end{array}$ & + & & + & & + & Cat, Inagua, 4, 5 . \\
\hline Kuntze. & & + & + & + & & Inagua. Widely dist. \\
\hline \multicolumn{7}{|l|}{ SOLANACE $\approx$} \\
\hline $\begin{array}{l}\text { Solanum aculeatissimum Jacq. } \\
\text { Solanum Bahamense L. }\end{array}$ & + & $\begin{array}{l}+ \\
+\end{array}$ & $\begin{array}{l}+ \\
+\end{array}$ & $\begin{array}{l}+ \\
+\end{array}$ & + & $\begin{array}{l}\text { I, 2, 4, 5. } \\
\text { Eleuthera, Cat, Watlings } \\
\text { Crooked, }\end{array}$ \\
\hline Solanum nigrum $\mathrm{L}$. & + & & + & + & + & Inagua, $I, 2,4$. \\
\hline Solanum nigrum nodiflorum Gray. & + & + & + & & & Inagua, $I, 3$ \\
\hline Solanum verbascifolium L. & + & + & + & + & & Eleuthera. Widely dist. \\
\hline $\begin{array}{l}\text { Physalis angulata L. } \\
\text { Physalis Barbadensis Tacq. }\end{array}$ & & + & + & + & + & $\mathrm{I}, 2,3,5$. \\
\hline Capsicum baccatum L. & + & & + & & & Widely distributed. \\
\hline Cestrum pallidum Lam. & + & + & & & & Cat, $i, 6$. \\
\hline Datura Metel L. & & + & + & + & + & Inagua. Widely dist. \\
\hline \multicolumn{7}{|l|}{ SCROPHULARIACEE } \\
\hline Stemodia maritima L. & + & & + & & & Eleuthera, I, 5 \\
\hline Capraria biflora L. & + & + & + & + & & $\begin{array}{l}\text { Cat, Watlings, Crooked, } \\
\text { Inagua. Widely dist. }\end{array}$ \\
\hline Buchnera elongata $S w$. & & + & + & + & + & $I, 3,4,5$ \\
\hline $\begin{array}{l}\text { Gerardia maritima Raf. } \\
\text { Gerardia purpurea } \mathrm{L} \text {. }\end{array}$ & & $\begin{array}{l}+ \\
+\end{array}$ & & $\begin{array}{l}+ \\
+\end{array}$ & + & \\
\hline \multicolumn{7}{|l|}{ LENTIBULARIACE $\bar{x}$} \\
\hline Pinguicula pumila Michx. & & + & & + & + & \\
\hline \multicolumn{7}{|l|}{ BignONIACER } \\
\hline Tecoma lepidophylla Griseb. & & + & + & & & \\
\hline Tecoma Bahamensis Northr. & + & + & & & & \\
\hline $\begin{array}{l}\text { Tecoma stans (L.) Juss. } \\
\text { Jacaranda Bahamensis R. Br. }\end{array}$ & + & + & + & + & & Inagua, $I, 2,3,4$. \\
\hline
\end{tabular}




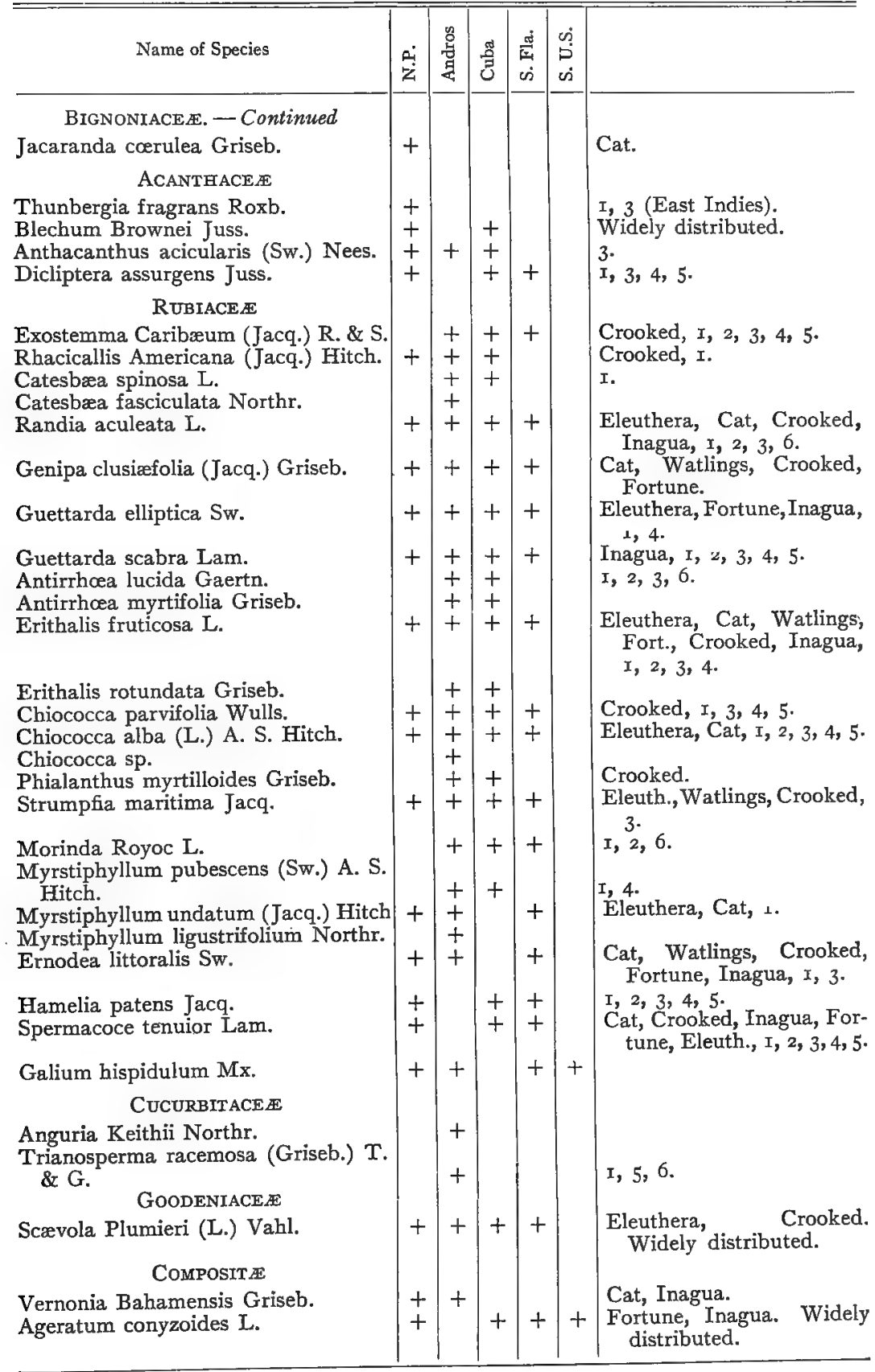




\begin{tabular}{|c|c|c|c|c|c|c|}
\hline Name of Species & $\begin{array}{c}0 \\
\text { 台 }\end{array}$ & 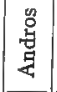 & 今ే & $\begin{array}{l}\frac{\pi}{\omega} \\
\dot{m}\end{array}$ & $\begin{array}{c}\dot{D} \\
\dot{D} \\
\dot{\omega}\end{array}$ & \\
\hline $\begin{array}{l}\text { CowPosIre. - Continued } \\
\text { Eupatorium ageratifolium DC. } \\
\text { Eupatorium Bahamense Northr. } \\
\text { Eupatorium capillifolium (Lam.) } \\
\text { Small. } \\
\text { Eupatorium odoratum L. } \\
\text { Eupatorium villosum Sw. } \\
\text { Willughbæya scandens (L.) Kuntze. } \\
\text { Aster exilis Ell. } \\
\text { Baccharis dioica Vahl. } \\
\text { Erigeron quercifolium Lam. } \\
\text { Pluchea fotida (L.) B. S. P. } \\
\text { Pluchea camphorata DC. } \\
\text { Pluchea odorata (L.) Cass. } \\
\text { Parthenium Hysterophorus L. } \\
\text { Iva cheiranthifolia Kth. } \\
\text { Iva imbricata Walt. } \\
\text { Ambrosia hispida Pursh. } \\
\text { Isocarpha oppositifolia R. Br. } \\
\text { Borrichia arborescens DC. } \\
\text { Amellus aspera (Jacq.) Kuntze. } \\
\text { Salmea petrobioides Griseb. } \\
\text { Bidens leucantha Willd. } \\
\text { Flaveria linearis Lag. } \\
\text { Porophyllum ruderale Cass. } \\
\text { Pectis linifolia L. } \\
\text { Neurolæna lobata (L.) R. Br. } \\
\text { Erechthites hieracifolia (L.) Raf. } \\
\text { Emilia sonchifolia (L.) DC. } \\
\text { Anastraphia Northropiana Greenm. } \\
\text { Anastraphia pauciflosculosa Wright. } \\
\text { Chaptalia albicans (DC.) H. } \\
\text { Sonchus oleraceus L. } \\
\text { Tridax procumbens L. }\end{array}$ & $\begin{array}{c}+ \\
+ \\
+ \\
+ \\
+ \\
+ \\
+ \\
+ \\
+ \\
+ \\
+ \\
+\end{array}$ & $\begin{array}{l}+ \\
+ \\
+ \\
+ \\
+ \\
+ \\
+ \\
+\end{array}$ & $\begin{array}{l}+ \\
+ \\
+ \\
+ \\
+ \\
+\end{array}$ & $\begin{array}{l}+ \\
+ \\
+ \\
+ \\
+ \\
+ \\
+ \\
+\end{array}$ & $\begin{array}{l}+ \\
+ \\
+ \\
+ \\
+ \\
+\end{array}$ & $\begin{array}{l}\text { I, 3, 4, 5, } 6 . \\
\text { Cat, I. } \\
\text { I, 3, 4, 5. } \\
\text { Eleuthera, Inagua, I, 2, } 3 . \\
\text { I, 3, 4, 5. } \\
\text { Inagua, I, 2, 3, 4, 5. } \\
\text { Eleuthera, Cat, Inagua, I, } \\
\quad \text { 2, 3, 4, 5. } \\
\text { Eleuthera, Crooked, For- } \\
\quad \text { tune, I, 4. } \\
\text { I. } \\
\text { Cat, Crooked, I, 2, 3, 5. } \\
\text { Eleuthera, Fortune, I, 2, } \\
\quad 3,4,5 . \\
\text { Grand Cayman. } \\
\text { Eleuthera. Widely dist. } \\
\text { I, 3, 4, 5. } \\
\text { I, 2, 3. } \\
\text { I, 3, 4, 5. } \\
\text { Widely distributed. } \\
\text { Widely distributed. } \\
\text { Fortune, Crooked, Inagua, } \\
\quad 6 . \\
\text { I, 4, 5. } \\
\text { Eleuthera. Widely dist. }\end{array}$ \\
\hline
\end{tabular}

\section{Summary of Above Table}

Total found on New Providence and Andros (exclusive of cultivated and escaped plants),

Of these there bave been reported

From other islands of the group, $\quad$ I76

From Cuba,

From South Florida,

From southern United States,

From Jamaica,

From Virgin Islands,

From Windward Islands,

From Mexico and Central America, $\quad$ I97

From South America, 
Of these 453 species, 76 are widely distributed, being common in warm countries on both continents.

Distribution of the t28 Spectes found in New Providence and AnDROS, BUT NOT REPORTED FROM CUBA

Peculiar to the Bahamas,

Found in south Florida,

Found in southern United States,

Found in Jamaica,

20

Found in Virgin Islands,

Found in Windward Islands,

Found in Mexico and Central America,

Found in South America,

IO

Found in Haiti,

IO

The 34 species that are apparently endemic are as follows: Pinus Bahamensis, Acacia choriophylla, Buxus Bahamensis, Passifora pectinata, Jacaranda Bahamensis, Jacaranda carulea, Vernonia Bahamensis, Thouinia discolor, Casalpinia ovalifolia, Phyllanthus Bahamensis, Casearia Bahamensis, and Reynosia Northropiana; and the following described and figured as new in this report: Thrinax Bahamensis, Paurotis Androsana, Cyclospathe Northropi (the last two new genera), Hymenocallis arenicola, Vanilla articulata, Pithecolobium Bahamense, Cassia Caribaa, Linum Bahamense, Erythroxylon reticulatum, Phorodendron Northropice, Helicteres spiralis, Xylosma ilicifolia, Terminalia spinosa, Tecoma Bahamensis, Catesbaa fasciculata, Myrstiphyllum ligustifolium, Crassopetalum coriaceum, Metastelma barbatum, Heliotropium nanum, Aletris bracteata, Anguria Keithii, Eupatorium Bahamense. Of the 34 species, 2I were found only on Andros.

Of the other species formerly considered endemic (Report of Committee appointed for Purpose of Exploring the Flora of the $\mathrm{Ba}$ hamas, W. T. Thiselton-Dyer, Sec., r888) Phialanthus myrtilloides and Antirrhoea myrtifolia have since been reported from Cuba; Salmea petrobioides has been reported by Hitchcock as occurring in Grand Cayman and Bletia purpurea has proved to be not distinct from $B$. verecunda.

Distribution of the 250 Species found in New Providence and ANDROS, AND aLso in SOUTH FLORIDA

Found in the United States, north of tropical Florida, 108

Found in Cuba, 202 


\section{FLORA OF NEW PROVIDENCE AND ANDROS}

Found in Jamaica, $\quad 198$

Found in Virgin Islands, $\quad$ I49

Found in Windward Islands, I6I

Found in Mexico and Central America, $\quad \mathbf{I}_{53}$

Found in South America, $\quad$ I53

Widely distributed, $\quad 68$

Species not hitherto reported outside of the United States, 18

Of these 18 species, 4 are limited to tropical Florida, the other I4 extend north of southern Florida.

Of the plants apparently restricted to the United States and the Bahamas, Dondia linearis was found only on New Providence; Smilax auriculata, Vitis rotundifolia, Sabbatia campanulata, Erigeron quercifolium, and Jacquinia Keyensis were collected on both islands while the following were found only on the island of Andros: Iva imbricata, Eugenia longipes, Mimusops Floridana, Myrica cerifera, Pluchea fotida, Salicornia Bigelovii, Polygala Boykinii, Samolus ebracteatus, Cynoctomum sessilifolia, Gerardia maritima, Gerardia purpurea, Pinguicula pumila. The last eight were confined to the western side of Andros, growing on the savannas, the border of the swash, or, in the case of the Pluchea, in damp spots in the pines. Myrica cerifera is said by Gardiner and Dolley to have been introduced from the United States.

The three reported by Hitchcock as being confined to the United States and the Bahamas are Xanthium strumarium, Vitis rotundifolia, and Distichlis spicata (the last found only in Inagua). The Vitis, he observes, may have been carried by birds, and the Smilax, Eugenia, and Mimusops are probably due to the same agency. Many of our seed-eating birds either spend their winters in the Bahamas or stop there on their migrations. Catbirds and mocking birds, for instance, were abundant on Andros during the winter and early spring.

The plants mentioned above as being found on the savannas and bordering the swash on the west side of Andros offer no inducements, however, to seed-eating birds, the fruits being dry and inconspicuous and the seeds in many cases minute. As has been noted before, the west side of Andros is a paradise for water birds, and they are found there in large numbers. Many of these birds, such as the great blue heron (Ardea herodias), the little blue heron (Ardea carulea), and the killdeer (Egialitis vocifera), are regular winter visitors from the United States. May it not be that some of these waders have at some 
time transported seeds of the plants in question, in mud that may have adhered to their beaks or feet? Their presence certainly seems very difficult to account for otherwise. Darwin says ("Origin of Species," chapter thirteen): "I have before mentioned that earth occasionally adheres in some quantity to the feet and beaks of birds. Wading birds which frequent the muddy edges of ponds if suddenly flushed would be the most likely to have muddy feet. Birds of this order wander more than those of any other, and they are occasionally found on the most remote and barren islands of the open ocean; they would not be likely to alight on the surface of the sea, so that any dirt on their feet would not be washed off, and when gaining the land, they would be sure to fly to their natural fresh-water haunts. I do not believe that botanists are aware how charged the mud of ponds is with seeds. I have tried several little experiments, but will here give only the most striking case: I took in February three tablespoonfuls of mud from three different points, beneath water on the edge of a little pond; this mud when dried weighed only $6 \frac{1}{4}$ ounces; I kept it covered up in my study for six months, pulling up and counting each plant as it grew; the plants were of many kinds and were altogether 537 in number, and yet the viscid mud was all contained in a breakfast cup! Considering these facts, I think it would be an inexplicable circumstance if water birds did not transport the seeds of fresh-water plants to unstocked ponds and streams situated at very distant points." The plants mentioned above are not water plants, it is true, but they are common in moist soil in the vicinity of ponds.

The seeds of Pluchea may owe their transportation to the wind. But whatever the means of dissemination, the fact seems established that although the bulk of the Bahaman flora has probably come from the south, there is a contingent, in the northern islands of the group at least, that owes its origin to the north. It is worthy of note in this connection that in a number of cases, when our plants were compared with large series of both Florida and Cuban specimens, they were found to resemble most closely the Florida specimens; hence when species occur in both Cuba and Florida, it may well be that the Bahaman plants owe their origin to the latter.

\section{Distribution within the Bahaman Group}

Species found on Andros,

Species found on New Providence, 
Species common to both islands, $\quad{ }_{5} 53$

$\begin{array}{ll}\text { Species reported from Eleuthera, } & 98\end{array}$

Cat Island, $\quad 79$

Crooked and Fortune islands, $\quad 79$

Inagua, $\quad 88$

Watlings, $\quad$ I8

(The above data for plants reported from the islands other than New Providence and Andros were taken from Hitchcock's Report.)

In addition to the plants collected by us in New Providence and Andros, Professor Hitchcock lists in his report I48 more, collected from the various islands of the group. Of these 36 are grasses and 30 are widely distributed or introduced species, while Epidendrum altissimum, Mimosa Bahamensis, Croton Eleuteria, Croton Hjalmarsonii, Pavonia Bahamensis, and Eragrostis Bahamensis are endemic, making a total of forty endemic species in the Bahama Islands. The last two had been previously undescribed.

\section{Notes on the Local Distribution}

The Bahama pine (Pinus Bahamensis), so abundant on New Providence and Andros, is confined entirely to the northern islands of the group, being found in addition only on Abaco, Bahama, and the Berry islands, the first two being on the Little Bahama Bank, and the latter a series of small cays on the Great Bahama Bank north of Andros.

Although, as we have seen, New Providence and Andros have many plants in common, some interesting points of difference were noted. The numerous introduced plants so common about Nassau, as Argemone Mexicana, Asclepias Curassavica, Abrus precatorius, Bidens leucantha, Ageratum conyzoides, etc., were, of course, entirely wanting on Andros, but, on the other hand, Aristolochiacer, Cactaceæ, Polygalaceæ, and Loranthaceæ were not seen on New Providence while represented by two or three species each on Andros. Passiflora pectinata, while very common in the pines on Andros (also reported from Turk's Island by Grisebach), was not found on New Providence, as was also the case with Hymenocallis arenicola, the latter growing luxuriantly on many of the sandy beaches of the former island.

Among the interesting plants found on Andros that have not 
been reported from New Providence are the following: Agave rigida, Casearia latioides, Pithecolobium Hystrix, Peltophorum adnatum, Ichthyomethia Piscipula, Euphorbia cassythoides, Lucuma pauciflora, Voyria Mexicana, Ipomea repanda, Petitia Domingensis, Vitex ilicifolia, Mimusops Floridana, and Morinda Royoc. With very few exceptions the plants found on the savannas of Andros were wanting on New Providence, and as they formed the most interesting feature of the Andros flora, it may be worth while to give the full list of plants found there. They were Sabbatia campanulata, Eustoma exaltatum, Bletia verecunda, Euphorbia buxifolia, Dichromena colorata, Cladium Jamaicense, Merospharum pectinatum, Gyrostachys tortilis, Flaveria linearis, Hypoxis juncea, Cynoctomum séssilifolia and C. Mitreola, Pinguicula pumila, Buchnera elongata, Gerardia purpurea and G. maritima, Polygala Boykinii and P. brizoides, Samolus ebracteatus, Limodorum tuberosum, Aletris bracteata, Chiococca alba parviflora, Buxus Bahamensis, Heliotropium nanum, Crassopetalum coriaceum, Rhamnidium punctatum, and Terminalia spinosa. Of these only the first six were collected on New Providence, and in addition to Rhamnidium punctatum, were the only ones found on Andros elsewhere than on the savannas.

On Andros itself, no Cactaceæ were noted in the northern part of the island, while Cereus Swartzii and two species of. Opuntia were quite common in the southern part, as they are said to be on the more southerly islands of the group. We also noticed that, whereas Vitis alata was very common on the northern half of the island, below that it was replaced by the allied species Vitis trifoliata.

On both islands mosses, lichens, and fungi were noticeably infrequent, and of the few species of each that were found none were common. 


\section{CULTIVATION OF SISAL IN THE BAHAMAS ${ }^{1}$}

\section{BY JOHN I. NORTHROP}

"ARE you interested in sisal? What do you think of it?" These were the questions addressed to the writer almost before he had landed in the Bahamas. 'The object of the writer's visit to the "land of the pink pearl" was to make a collection of its plants and animals; but, during the pleasant six months occupied in so doing, he had many opportunities of obsèrving the cultivation of the "sisal hemp." This industry is now in its infancy in the Bahamas, but, if the present prospects are realized, it will before long bring to the islands both wealth and prosperity. Since his return the writer has found that most of those to whom he has spoken of sisal had at best but a vague idea of the fiber or of the plant that produces it, so it was thought that some notes on the subject might prove of interest.

The group of coral islands known as the Bahamas lies east of southern Florida and north of Cuba. One of the islands, New Providence, is well known to those who, in search of health or recreation, have been to Nassau and enjoyed its lovely winter climate. But the "out islands," as the remaining ones are locally termed, are seldom visited, even by those who live in Nassau. The largest of these "out islands" is Andros, which is about the size of Long Island, New York; there, as in all the others of the group, except New Providence, the population is almost entirely composed of negroes, only seven white men living on the island; and of these, four are interested in the production of the fiber known as sisal hemp.

The term "fiber" is used commercially to designate the material obtained from the leaves or stems of many different plants. Hemp, on the contrary, refers to the product of a single plant, known botanically as Cannabis sativa, and belonging to the same order as our hop. But in speaking of fibers the word "hemp" is often added, and thus we hear of "sisal hemp," or, as it is sometimes called, "sisal grass,"

\section{${ }^{1}$ Popular Science Monthly, March, I8gr.}




\section{CULTIVATION OF SISAL IN THE BAHAMAS 213}

or even manila. The latter term, however, is properly restricted to the fiber obtained from a species of plantain (Musa textilis) belonging to the same genus as the banana.

Sisal hemp, the subject of this paper, is obtained from the leaves of some of the species and varieties of the genus Agave, one species of which is well known in cultivation under the name of "century plant." This genus belongs to the order Amaryllidacece, and is related to the snow-drop, amaryllis, and narcissus; but, owing to the much greater size of the plants, and some peculiar points of structure, it stands prominent among its congeners. The agaves are indigenous in the New World only, and the majority of the species are natives of Mexico, only a few being known within the limits of the United States.

The same general appearance is presented by all, so that any one familiar with the century plant can form a very good idea of the appearance of the other species of the genus. In all, the leaves are thick and fleshy, as they contain the supply of material which is to nourish the great flower-stem when the plant arrives at maturity. This stem, which is a prolongation of the trunk of the plant, shoots up from the center of the rosette of leaves, and often attains a height of from twenty to thirty feet. The time required to arrive at maturity varies in the different species, and in the same species under different conditions. The "century plant" in its native home, Mexico, blossoms in from ten to fifteen years, while with us it requires thirty, fifty, or in some cases, it is said, even a hundred years to mature. During the production of the great flower-stalk the store of nourishment in the massive leaves is exhausted, and, after the fruit is produced, the plant withers and dies.

The leaves of all the agaves contain what are known botanically as the fibro-vascular bundles. In order to see these, it is only necessary to cut off a leaf of the century plant; as, in a thick transverse section that has been allowed to dry slightly, the fibers will look like short bristles projecting from the surrounding soft tissue; and in a longitudinal section these bristly points are seen as threads running through the leaf. Should the observer be the fortunate possessor of a compound microscope, on examining these threads he will find them composed of exceedingly fine, elongated cells, closely connected in a bundle, and surrounded by the much larger circular cells that compose the soft parts of the leaf. When the outer skin and the soft tissue of the leaf 


\section{CULTIVATION OF SISAL IN THE BAHAMAS}

are removed, the fibro-vascular bundles remain and constitute what is commercially known as "fiber."

While all the agaves will yield fiber of some kind, it is only in a few that the quantity and quality of the material are such as to make its manufacture profitable. This fact has been known for a long time in Yucatan, the home of the sisal industry. There the natives have from time immemorial cultivated a number of agaves, until now it is difficult for botanists to decide whether some of them are distinct species or only cultivated varieties.

One of the native species, known as Agave rigida, is a rather small plant, having leaves from two to four feet long, and as many inches wide. These are armed on the edges with dark brown spiny teeth, and are terminated by a stout reddish brown spine. This seems to be the plant called chelem by the natives of Yucatan, and is the one from which the cultivated varieties are supposed to have originated. These varieties, collectively known as henequen or jenequen, are separately distinguished as the "yaxci, furnishing the best quality, and the sacci, with the largest quantity of fiber; chucumci, larger than the last, produces coarse fiber; and $b a b c i$ has finer fiber, but in smaller quantity."

Of the varieties mentioned above, only two need be considered the sacci and the yaxci. The former, known as Agave rigida, var. longifolia, is distinguished from the native plant by having much longer, spiny leaves, from four to six feet in length, and slightly different flowers. It is extensively cultivated in Yucatan, and, as already stated, yields the most fiber. The other variety, the yaxci, botanically dignified by the title Agave rigida, var. sisalana, or sometimes even elevated to the rank of a species, is one of the most valuable of the fiber-producing agaves.

The leaves are of a dull green color, four to six feet long, as many inches wide, and terminated by a stout, dark spine. The margins are commonly described as smooth, as they are without teeth, but in all the plants examined by the writer the leaves were slightly rough on the edges, and in many of the young plants some of the leaves had welldeveloped teeth. A full-grown plant presents a rather striking appearance, bristling all over with the long, spiny-tipped leaves, thickly radiating from the short cylindrical trunk, which is crowned by a sharp, slender, cone-like bud. Indeed, a large plant makes one think of a 
gigantic sea-urchin. The leaves as they unfold from the bud slowly assume a horizontal position, but remain rigid and straight, never curving downward, as they do in the century plant.

As has been said above, when the plant arrives at maturity, and has a sufficient store of nourishment, it sends up its flower-stem, known

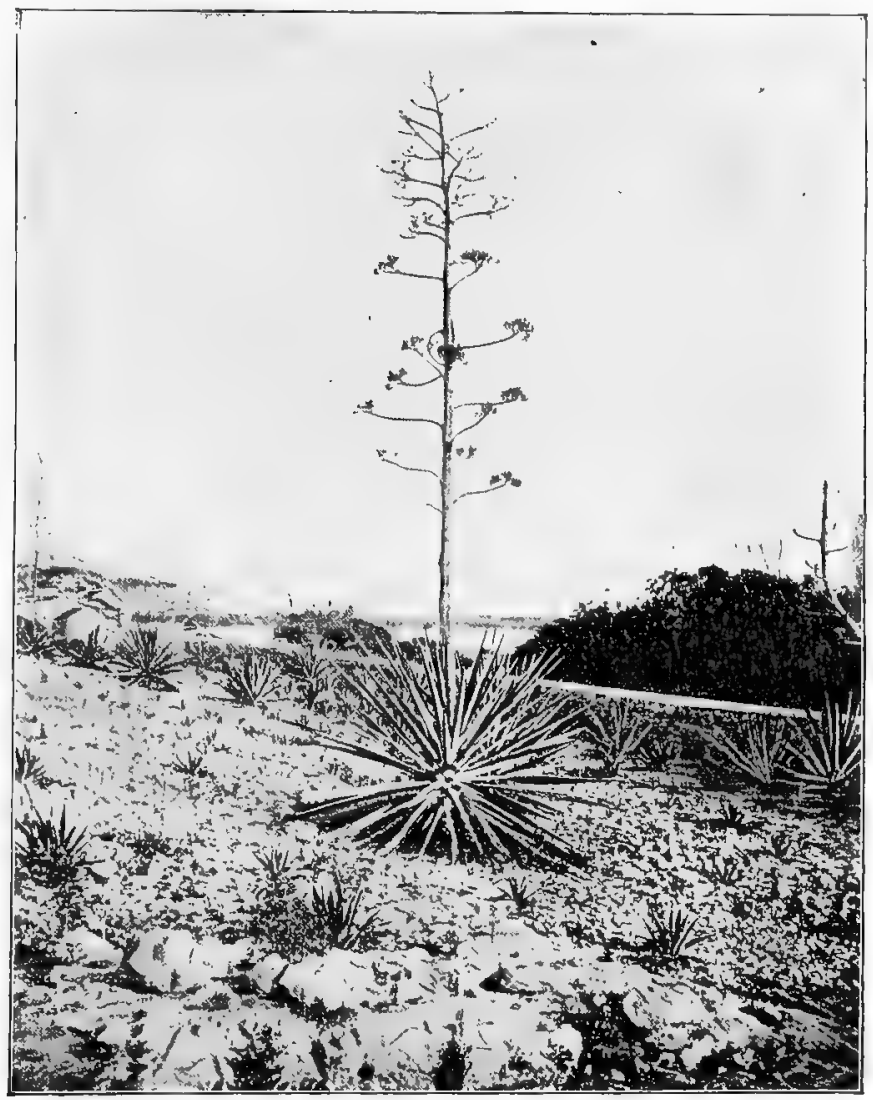

FIG. 6. - Agave rigida, var. sisalana, in blossom, near Nassau, N. P.

to cultivators as the "mast" or "pole." This is from twenty to twentyfive feet high, and about six inches in diameter near the base. On the upper two-thirds branches are developed, converting the pole into a huge panicle, covered with innumerable greenish yellow flowers. A peculiarity of the sisal plant is that it seldom or never sets a seed. The flowers fall, carrying the ovary with them, then on the ends of the 


\section{CULTIVATION OF SISAL IN THE BAHAMAS}

branches young plants develop, so that the pole presents a rather odd appearance, with the small plants growing out in the places usually occupied by the flowers. When these young plants have attained a height of from three to four inches, they fall to the ground and take root. The old plants also reproduce themselves by means of suckers,

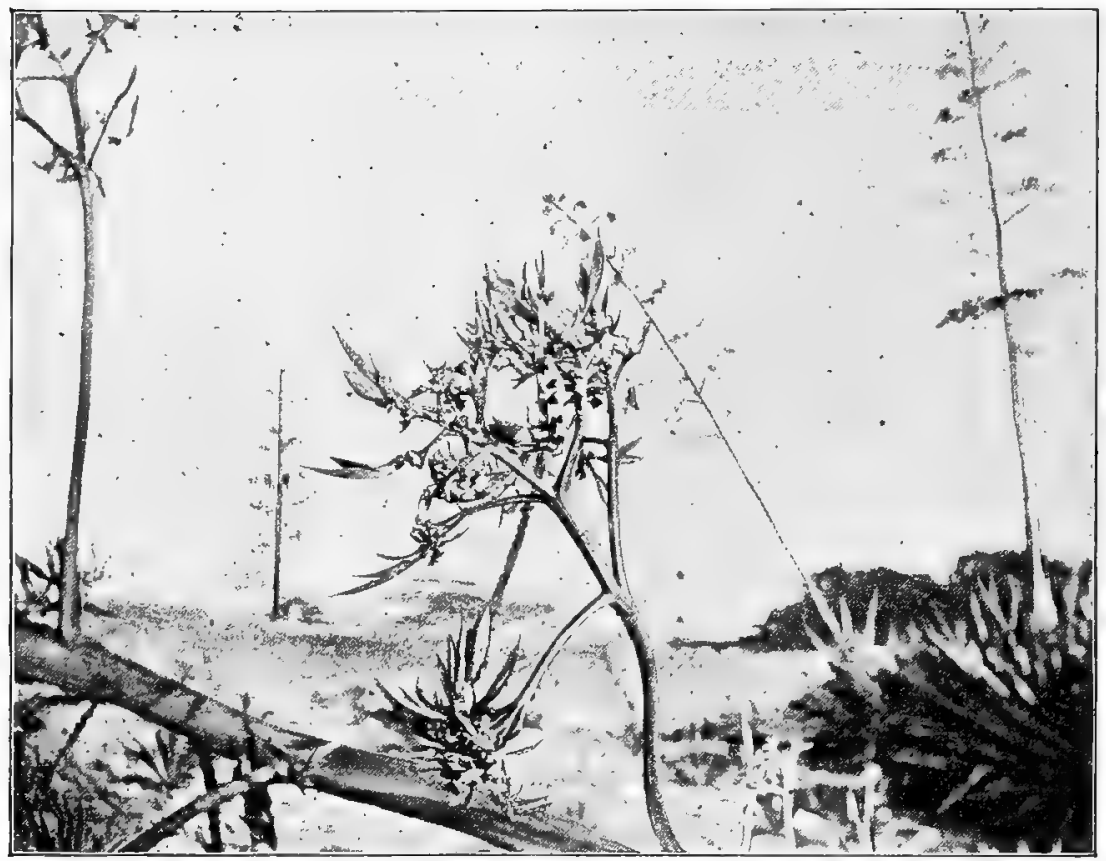

FIG. 7. - A Branch of the "Pole" of the Sisal Plant.

and hence, when old and neglected, are often seen surrounded by numerous smaller ones, as in the common houseleek (Sempervivum).

Such is briefly a general description of the plant that seems destined to occupy the capital and energies of the people of the Bahamas; for it was this plant that was introduced there a few years ago by Sir Henry Blake, ${ }^{1}$ then governor of the colony. Although the plants were neglected, they throve and increased to such an extent that finally the people looked upon them as troublesome weeds, and as such they were

${ }^{1}$ Governor Blake is generally credited with having introduced the plants. But as early as I854 an agave was sent by the British vice-consul, Baldwin, from Florida to the Bahamas. It is not unlikely that this plant was the same as those introduced by Dr. Perrine into Florida. 
often destroyed. Their usefulness, however, was evidently appreciated by a few; for, as Sir Ambrose Shea, the present governor of the Bahamas, told the writer, he was one day passing the house of a native, when a piece of rope attracted his attention. On inquiring where he obtained it, the negro replied that "it growed in de yard," and showed the governor the plant, and explained the way in which the rope had been made. Now, Sir Ambrose happened to be a native of Newfoundland, and hence knew a good rope when he saw it; so inquiries were at once made, and the value of the plants was learned.

The people, however, were slow to realize the importance of the subject, but the governor evinced great energy and enthusiasm in keeping it before them, and when some of the fiber obtained from old plants sold in London at the rate of fifty pounds per ton, and was declared to be superior to that produced in Yucatan, sisal in the Bahamas had somewhat of a "boom," and people carefully guarded the very plants that formerly they would have destroyed as weeds. Everybody became enthusiastic, and sisal plantations were everywhere started, not only by the people of the colony, but also by outsiders, as the following facts show.

A company from St. John's, Newfoundland, has obtained a grant of 18,000 acres of crown land at Abaco; another tract of 20,000 acres on the same island has been allotted to a London company; 2000 acres have been taken on Andros by a gentleman from Edinburgh; I200 are in process of cultivation on Inagua; but the largest application has been lately made by two London companies, who together ask for 200,000 acres. Besides the large plantations mentioned above many small scattered areas go to swell the total. Indeed, there have been so many demands for crown land that the governor has recently advanced the price from one dollar and twenty-five cents to four dollars per acre.

Now as to the character of the land. In Andros, which, as above stated, is the largest of the group, and where most of the writer's time was passed, the land is locally described by one of three terms: it is either "coppet," "pine-yard," or "swash." The coppet, which occupies, as a rule, the more elevated parts of the island, is composed of small angiospermous trees, often only two or three inches in diameter, and so close together as to make an almost impassable thicket. Back of the coppet, which is mostly a fringe along the eastern coast, nearly 


\section{CULTIVATION OF SISAL IN THE BAHAMAS}

the whole interior is one vast "pine-yard," made up of the Bahama pine (Pinus bahamensis). The trees are generally small, and from ten to twenty feet apart. Under them is very frequently a dense undergrowth of a tall brake, which is often six or seven feet high, and is known by the natives as "May-pole."

"Swash" is a very expressive term to denote the low swampy ground, of which there are thousands of acres on the west coast. Here

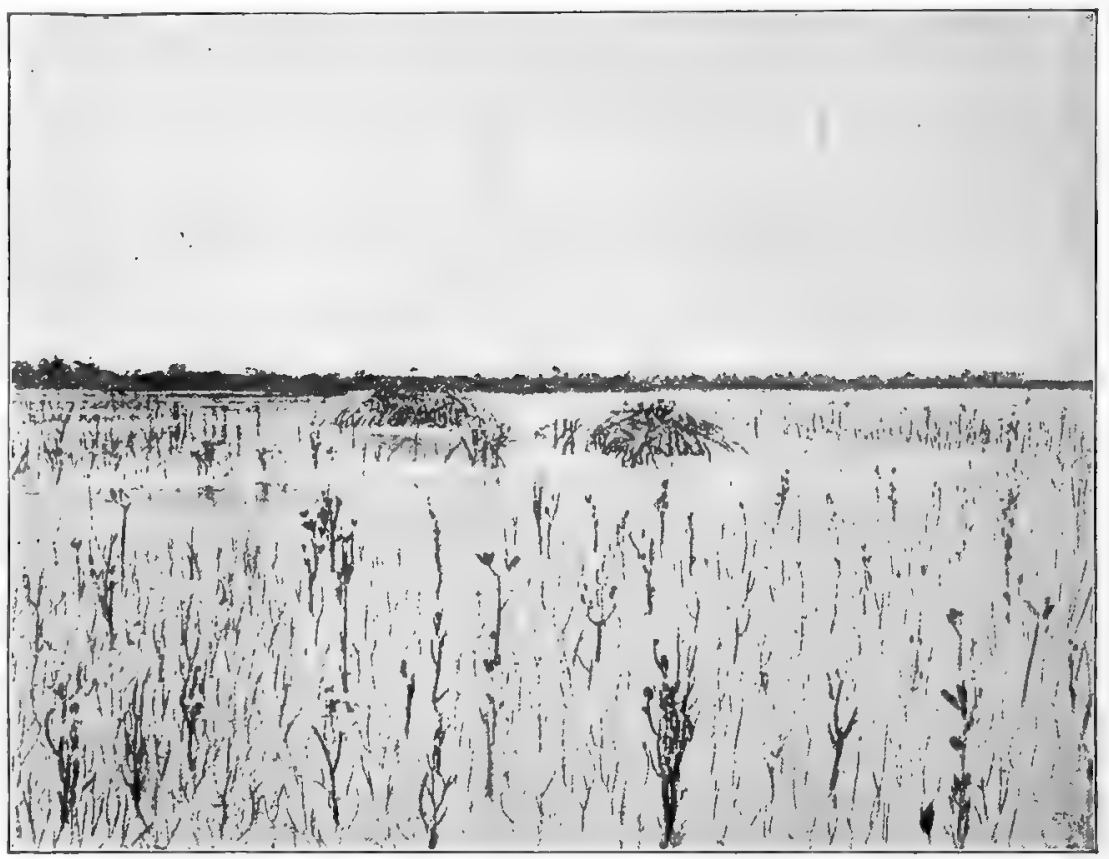

FIG. 8. - "Swash," West Side of Andros.

the soil is soft and is composed of comminuted calcareous particles; it supports no regetation except innumerable small mangroves ( $R h i$ zophora mangle), here and there small "button-woods" (Conocarpus erectus), a few "salt bushes" (Avicennia nitida), and in some places palmettoes. So far as sisal cultivation is concerned, the swash is utterly valueless; but the pine-yard and coppet are both available. In neither of these, however, is there what we recognize here as "soil"; and at first it was a source of wonder to the writer that anything at all could grow there, for the surface is very largely the bare coral rock. 
However, it is rarely smooth, but is rough and jagged with innumerable points and crevices, so as to resemble somewhat the appearance of a well-thawed mass of snow-ice. In most places, also, there are numerous holes, from a few inches to many feet in diameter; and it is in these holes, cracks, and crevices that what little earth there is can be found - still, this little seems sufficient to support the dense vegetation. Some of the other islands - Eleuthera, for instance - have consider-

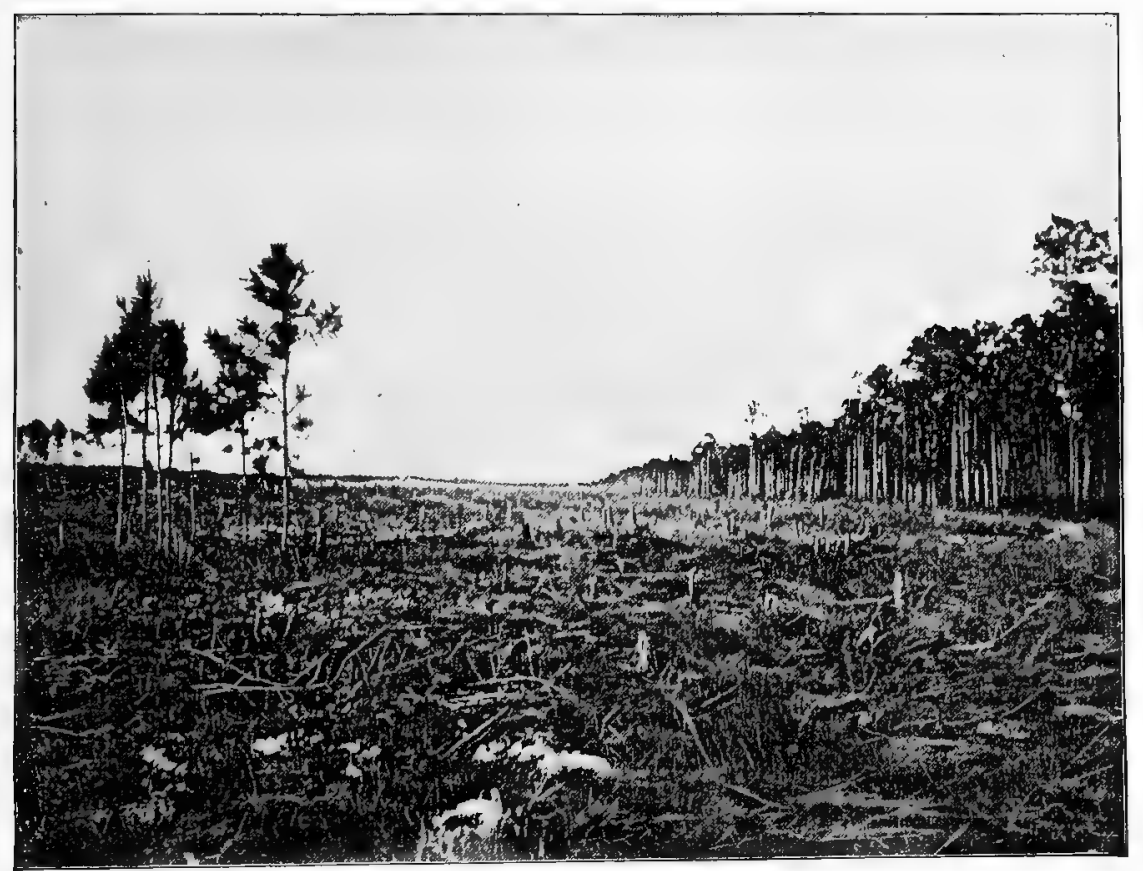

FIG. 9. - Clearing the "Pine-yard" for Sisal near Nassau, N. P.

able depth of soil; but it is when growing on the bare, rocky ground described above that the sisal is said to produce fiber of the best quality.

Given the land, the next step is to clear it, and the method of clearing varies according to the character of the vegetation. If it is pineyard, a fire is started, which burns off the May-pole; the pines are then cut down, and either made into charcoal or laid in rows across the fields and allowed to decay; if coppet, the trees and shrubs are cut down with axes or cutlasses, according to their size, and the brush is then burned. 
While his land is being cleared, the planter should be getting his plants ready. As usually obtained, they are fresh from the "pole," and only from one to four inches in height. These are too small to put out in the fields, so they are set out in beds of cave earth until they get to be eight or ten inches high. When taken from these nurseries their rootlets are carefully trimmed off, and they are then planted every eight or nine feet in rows that are about ten feet apart. Thus an acre of ground usually contains from five to six hundred plants. In order to facilitate carrying the leaves out of the field, the latter is divided by roads into sections of about one hundred acres each.

After planting, it is not very long before the fields will have to be weeded, and this process is said to be necessary about twice a year, until the sisal plants attain a height of three or four feet, when weeding is no longer needed. The most troublesome enemy of the planter, in the way of weeds, is the "May-pole," as it grows very rapidly, but the roots are said to die after the third cutting. In about four years the sisal plant produces what are called "ripe leaves"-- that is, leaves that are horizontal and large enough to cut. The cares of the cultivator are now about over, and all he has to do is to cut off the leaves as fast as they mature, and manufacture his fiber.

The cultivation of sisal is of such recent introduction into the $\mathrm{Ba}-$ hamas that as yet none of the large plantations have begun to produce to any extent; so for a description of the next stages we will turn to Yucatan, where, as has been said, the industry has been carried on from time immemorial. There the men cut the leaves off close to the trunk, and lay them tip to butt in bundles of fifty, when they are carted to the machines. The cutting of thirty bundles, or fifteen hundred leaves, is considered a good day's work. In order to save the cost of transportation, as the leaves yield but about five per cent of fiber, there is usually a machine to every one hundred acres. The machine now in use consists of a horizontal wheel, on the face of which brass strips are transversely placed, forming dull knives. The leaf is introduced so as to bring one side in contact with the revolving wheel, which is run by a small engine. A brake then presses the leaf against the scrapers, while the butt is firmly held by a pair of pincers. The scrapers remove the outer surface and some of the soft tissue; then the leaf is taken out and turned, and the other side undergoes the same operation, until only the fibers are left. These are then shaken out and 
hung in the sun for a few hours to dry. The result is a rather coarse fileer of considerable strength. The tinest quality is nearly white. while the inferior gratles are yellowish in color. In order to produce the best quality of lilser, the leaves muat be cleaned as soon as possible after being cut; otherwise the fiber is apt to be spotted.

It may be well to state here that the cultivation of sisal is also being tried in Bermuda, Trinilad, and Jamaica, but on a much smaller

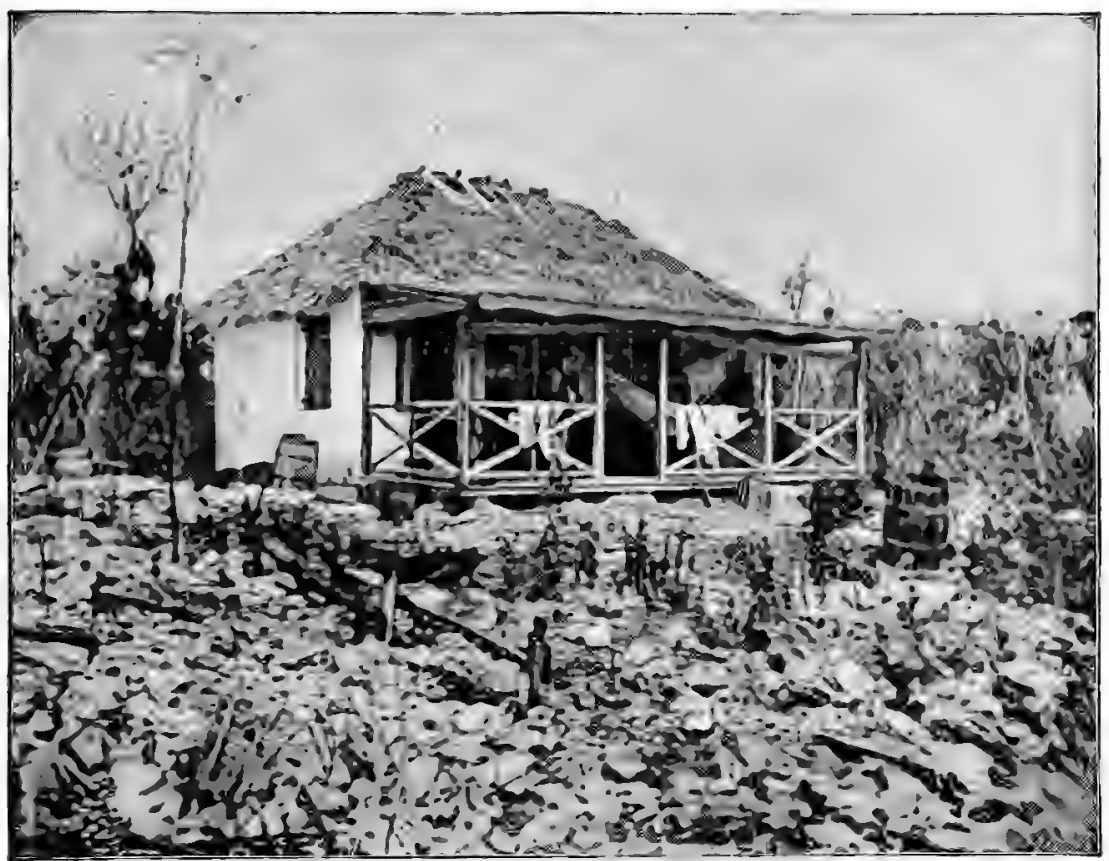

FIG. 10. - The Fouse of a Sisal Planter, Andros.

scale than in the Bahamas. There, as alrearly staterl, large tracts of land have been bought from the government for the sole purpose of producing the sisal hemp. The price is now four dollars an acre, and two acres are said to produce one ton of tiber. Wages for men vary from thirty-six to sixty cents per day, according to the season and locality, as most of the negroes are spongers, and at certain times of the year labor is not easy to obtain. Women, however, are largely employed in the planting and wecting, and receive on the average twenty-five cents a day. These are the data on which it is stated that 
a ton of fiber can be produced for $\$ 50$. As the price of the fiber is now from $\$ 120$ to $\$ 130$ a ton, and has been as high as $\$ 200$, these figures look attractive.

But it may well be asked, "How about the quantity of fiber now on the market, and will the market stand the enormous increase, that the yield of the Bahamaswill give?" That is, of course, the very point on which the question of profit or loss will turn. The writer has been told, by one who is well acquainted with the fiber market, that if the sisal hemp could be sold for four and a half or five and a half cents per pound, in a few years the consumption would be doubled; for, when the price reaches nine or ten cents a pound, the use of the fiber for many purposes is abandoned, and is replaced by some cheaper material, as jute.

One of the principal obstacles in the way of cheaper fiber is the need of a good machine, as the one now in use is a crude affair, requiring the attendance of two men and a boy besides the engineer, and producing but a small quantity of fiber daily. Although much skill and money have already been spent in attempting to invent a better machine, as yet all efforts have been unsuccessful; but, as inventors and mechanics are still at work, and as the recent "sisal boom" in the Bahamas will increase the demand, there is little doubt but that here, as in so many other cases, necessity will prove the mother of invention. When the fiber can be cheaply produced in large quantities, there is little doubt but that increased uses will be found for it, and that the demand will equal the supply.

In 1887 Yucatan exported crude fiber valued at over $\$ 3,000,000$, besides $\$ 37,862$ in rope and $\$ 43,89$ I in hammocks. About eighty-four per cent of the crude fiber and fifty per cent of the hammocks came to the United States; most of the remaining fiber went to England, Germany, and France, while Spain took the rest of the hammocks and all the rope. In 1889 the import of sisal hemp into the United States was between $\$ 6,000,000$ and $\$ 7,000,000$, about 50,000 tons, on which a duty of $\$ 5$ a ton was paid. ${ }^{1}$

Now it may be asked: "Why cannot the United States produce sisal too? Is no portion of our vast territory suitable for this crop?" As we shall see, some one did ask that question over fifty years ago. It is not generally known that in 1827 the Treasury Department issued

${ }^{1}$ The duty has since been removed. 
a circular to some of the American consuls, requesting them to collect and preserve seeds and specimens of such plants in their districts as were "useful as food for man or the domestic animals, or for purposes connected with the manufactures or any of the useful arts." The American consul at Campeche, Dr. Henry Perrine, responded to this call with energy and enthusiasm, and soon introduced into Congress "a bill to encourage the introduction and promote the cultivation of tropical plants in Florida, and conveying to Dr. Perrine and his associates a township of land, on condition that every section should be forfeited if at least one-fourth thereof should not be occupied and successfully cultivated in tropical or other plants within five years." These hard conditions were accepted by Dr. Perrine, and in one of his letters to Congress he calls attention to the sisal plant, and says, "He repeats his unbroken conviction that its introduction will make an era of as great importance to the agricultural prosperity of our confederation as the invention of the cotton-gin."

For nearly ten years he labored, sending to Florida plants and seeds, and endeavoring to obtain his township of land, desiring "no more honor than the power of passing the brief term of his painful existence amid the privations and exposure incident to a chief pioneer in the planting and population of tropical Florida." He finally succeeded in establishing a sisal plantation on Indian Key. Unfortunately, Dr. Perrine was not permitted to see the result of his labors, for, during the Seminole War, the Indians set fire to his buildings, and he himself fell a victim to their merciless attack. With the death of Dr. Perrine ended the cultivation of the plants he had introduced; but one of them, that he named Agave sisalana, remained, became naturalized, and is now flourishing on some of the Florida Keys, where the young plants are now being gathered and carried to the Bahamas.

Thus we see that the plants are growing within our borders, and it is only necessary to determine the quality of their fiber; for, although the plants are the same species as those now cultivated in Yucatan and the Bahamas, the quality of the fiber may not be as good, and yet on the other hand it may be better. For instance, it is said that the $\mathrm{Ba}$ hama fiber is superior to that produced in Yucatan; so why may not the "Florida fiber" of the future surpass that of the Bahamas? In order to determine its value it is only necessary to prepare it by hand from the plants now growing in Florida and compare it with the article 


\section{CULTIVATION OF SISAL IN THE BAHAMAS}

now on the market. The subject is being investigated by the Department of Agriculture, and a report may be looked for in the near future.

It may be said in conclusion that, as a crop, sisal has much to recommend it. It grows best on barren, rocky land that is useless for other agricultural purposes. Drought affects it but little, if at all, as the writer can testify from his own observation. The yield is not confined to any one season, but is continual; hence the employment of labor is constant, and the planter can estimate closely what the yield will be for a given time. The old plants are easily replaced by the suckers that have been previously cut off and kept for this purpose. These advantages are shared by all the cultivators of sisal; but, in addition, the planter in Florida will have at his door a market that now absorbs eight-four per cent of all the fiber produced. He will not only bring into use land now almost worthless, but will probably make for himself a fortune and introduce a new industry into the United States. 


\section{MISCELLANEOUS PAPERS}

BY

JOHN I. NORTHROP 



\title{
THE ERUPTION OF KRAKATOA IN $1883^{1}$
}

\author{
By JOHN I. NORTHROP
}

EvERY ONE has heard or read of the effects of a volcanic eruption, but the cause of the outbreak is more frequently wondered at than understood.

The old Greeks and Romans were content to consider the volcanoes of which they had any knowledge as the property of one of their gods or the abiding place of departed spirits; and for a long time superstition and fear prevented accurate observation of volcanic action. About a hundred years ago the illustrious Italian naturalist, Spallanzani, published the results of his study of the volcanoes of his native land, and since that time many workers have entered the field, and our knowledge has steadily increased, until a science has been created and called Vulcanology.

The volcanoes of the world, with two exceptions, have been found to form four irregular lines upon its surface, thus indicating the existence of as many great fissures in the so-called crust of the earth. The exceptions are the volcanoes of the Sandwich Islands and those of the Thian Shan range in the central part of Asia. The lines of volcanic action, as a rule, follow the coasts of the continents, and with the exceptions already noticed, the volcanoes are situated in close proximity to the bodies of water they border. This fact has led vulcanologists to look to the oceans for an explanation of volcanic eruptions.

The line separating fusion from solution is not a sharp one, for it has been shown by adding niter to a given quantity of water, that when the cold solution becomes saturated, it is only necessary to apply heat to dissolve still more of the salt. By increasing the heat and the addition of niter, a point may be reached where the mixture can no longer be called a solution, but must be considered a fusion. It has also been proved that rocks containing a certain percentage of water are more

${ }^{1}$ School of Mines Quarterly, Vol. X, No. 2, January, I889, pp. I-I5. 
fusible than those that contain a smaller proportion, and it is well known that among the minerals some, as the zeolites, are fusible, while others, containing no water, are practically infusible.

The primary cause of a volcanic outbreak is the heat that is present below the surface of the earth, but it is the slow, very slow, percolation of a small quantity of water through the rock that is supposed to aid in the fusion. During this process gases are produced that gradually increase in pressure, until at last force enough is generated to overcome the weight above, and an eruption is the result. It has been suggested that a sudden inrush of the sea through a fissure to the molten lava would give rise to an evolution of steam sufficient to cause an eruption, but Professor Judd claims that the effect upon the lava would be to form a crust of chilled material under the water, which would confine the volatile products generated below, and only when the pressure of these gases became greater than the load above would an outbreak occur.

Most of the material ejected from a volcano falls close to the vent, thus forming a cone that continues to increase in height, until an eruption of exceptional violence entirely removes the upper portion, leaving a ring or crater that Darwin has aptly called the "basal wreck." Within this crater a new cone may be built up, and the former outline of the mountain be restored, to be once more destroyed in its turn.

In the Strait of Sunda, between the islands of Java and Sumatra, are portions of an old crater ring, which, rising above the water, form the islands of Krakatoa, Verlaten, Lang, and Polish Hat. One of the grandest lines of volcanic activity on the earth runs through these islands, and is continued eastward through the islands of Bali, Sum- . bawa, Flores, and Timor. There is evidence that a second fissure crosses this main one at nearly right angles, and at the intersection of these two lines Krakatoa is situated. Notwithstanding the important position it occupied, until recently this little island received but a small share of the attention that geologists have given to volcanoes in general. But this is not to be wondered at when it is remembered that Java contains "no fewer than forty-nine volcanic mountains, some of which rise to a height of $\mathrm{r} 2,000$ feet above the sea level," and a few are in a state of almost constant activity. In recent geological times Krakatoa, though now insignificant, rivaled these mountains in size, for if the conclusions that geologists have drawn are correct, the present 
islands of Krakatoa, Verlaten, Lang, and Polish Hat are but the remains of the "basal wreck" of a volcano that rose 10,000 feet above the sea, with a circumference, at its base, of twenty-five miles. At some unknown period an eruption took place that removed the central mass of this volcanic mountain, leaving a crater, about four miles in circumference, the highest points of which were but a few hundred feet above the surrounding water.

After a series of quiet eruptions that gradually filled up this old crater, a lateral or parasitic outburst seems to have taken place at its

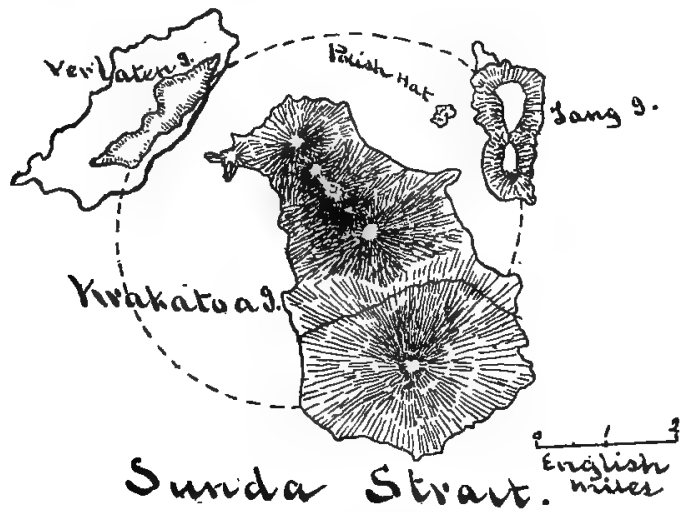

FIG. 1. - Map of the Islands of the Krakatoa Group before the Eruption of August, I883.

From the "English Krakatoa."

southern edge. This activity must have continued for a long time, as it resulted in the formation of a cone about 2600 feet in height. It is this cone "that was called by the natives the peak of Rakata, which, in the old Kawi or Javanese language, signifies a crab. The name, under the Dutch form, Krakatau, the Portuguese Krakatao, and the English Krakatoa, has been extended to the whole island upon which the striking cinder cone stood."

From the meager accounts that have been preserved, it seems that in May, $\mathrm{x} 68 \mathrm{o}$, an eruption occurred at some point on the island, and it is probable that Perboewatan was in activity, as fresh lava streams have been seen on its sides by several later authors.

The relative positions of Krakatoa and the adjacent islands are shown in Figure I. The broken line indicates the form of the old crater, of which the islands of Verlaten and Lang are portions rising above the 
strait. The cones within the ring were formed by the quiet eruptions that filled up the crater. The largest cone to the southwest is the peak of Rakata. During the late eruption almost all of the island Krakatoa, north of the line drawn through this peak, was removed. The increase of size of Verlaten Island is indicated by the line surrounding it. Lang Island was also slightly added to at the north.

Figure 2 is a section through the length of, the island of Krakatoa and shows its geological position. A thin bed of postertiary age (a) rests on the tertiary rocks below, and above it stood the old volcano, whose supposed form is indicated by the broken line. The lateral cone of Rakata is well shown, and also the position of the two small cones - Danan and Perboewatan.

After the eruption of Perboewatan in I680, for nearly two centuries Krakatoa remained scarcely noticed amid the grander peaks that surrounded it. But during this time the unseen forces below had been gathering strength, as if to resent this seeming neglect, and the first intimations of what followed were given by earthquakes, of frequent occurrence, that were felt as far distant as North Australia.

On May 20, I883, "sounds like the firing of artillery were heard at Batavia and Buitenzorg in Java, nearly Ioo English miles from Krakatoa." On the twenty-sixth of the same month a party was organized at Batavia and proceeded in a steam launch to the island. It was then seen that the cone of Perboewatan was again in activity. The party succeeded in taking a photograph of the volcano and returned to Batavia. The accounts of the subsequent disturbances are rather indefinite. According to Professor Judd, "the eruption from Perboewatan seems to have had sufficient force to carry the volcanic dust to various points along the shores of Java and Sumatra. After this sudden outburst there was a rapid and marked decline in violence, and then a gradual increase till June 24, when a second crater had opened in the center of the island. The eruptive force still increasing, a third crater made its appearance, and innumerable smaller vents were originated all over the surface of the filled-up crater of the great volcano. From this time the activity seemed constantly to increase till its grand culmination on the $27^{\text {th }}$ of August."

On that afternoon and through the succeeding night the forces Krakatoa had so long imprisoned broke loose with a violence unequaled in the records of volcanic activity, and caused the scientific 


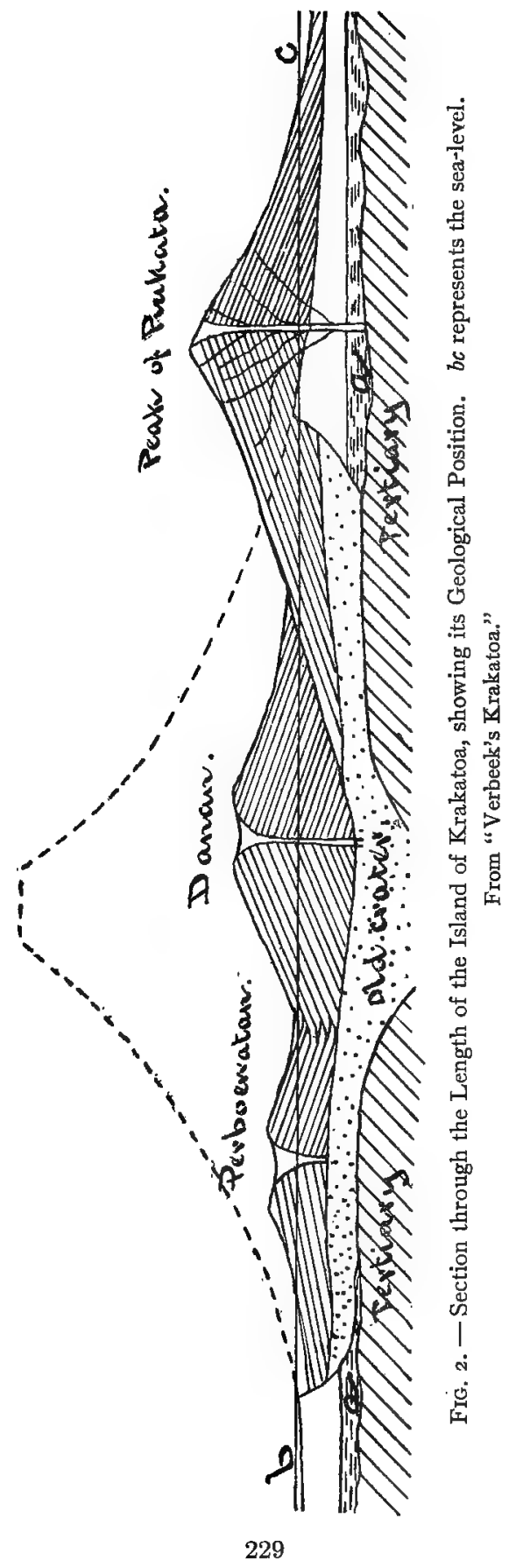


world to give this little island the attention for which it had waited so long.

Shortly after the eruption the Dutch government caused a careful survey of the vicinity to be made, and commissioned Mr. R. D. M. Verbeek, a mining engineer of Batavia, to investigate the cause and effects of the outbreak.

Later, the Royal Society of London took the matter in hand, and on January $\mathrm{I} 7, \mathrm{I} 884$, the council passed the following resolution: "That a committee, to consist of Sir F. Evans, Professor Judd, Mr. Norman Lockyer, Mr. R. H. Scott, General Strachey, and Mr. G. J. Symons, with power to add to their number, be appointed to collect the various accounts of the volcanic eruption at Krakatoa, and attendant phenomena, in such form as shall best provide for their preservation and promote their usefulness." The committee inserted a letter in the Times and other periodicals, inviting communications relating to the eruption. Later, Dr. Geikie and Professor Bonney were added to the committee. The work of discussing the mass of data collected was commenced about the end of November, I884. In the spring of r 887 the manuscript was completed, and has since been printed in a quarto volume of four hundred and ninety-four pages. The results of Mr. Verbeek's investigations were published in Dutch in I885-1886, and afterward translated into French.

It was suggested to me that a description of the eruption might be of interest to the readers of the Quarterly. Most of this article is based on the English work, as I have been unable to obtain the first volume of Mr. Verbeek's account.

During the night of August 27, 1883, the British ship, Charles $B a l$, being prevented by the intense darkness from continuing her voyage, beat about within a dozen miles of the east coast of Krakatoa. This vessel and two others in the vicinity escaped destruction. About 40 miles from the scene of the eruption were four other vessels, three being at the eastern and one at the western entrance of the strait; while many were at distances varying from 75 to rooo miles from the volcano. The account of what happened during that eventful night has been compiled from the data furnished by the officers and passengers of these vessels, and the reports collected with so much care by Mr. Verbeek.

The northern portion of the island of Krakatoa was almost entirely 

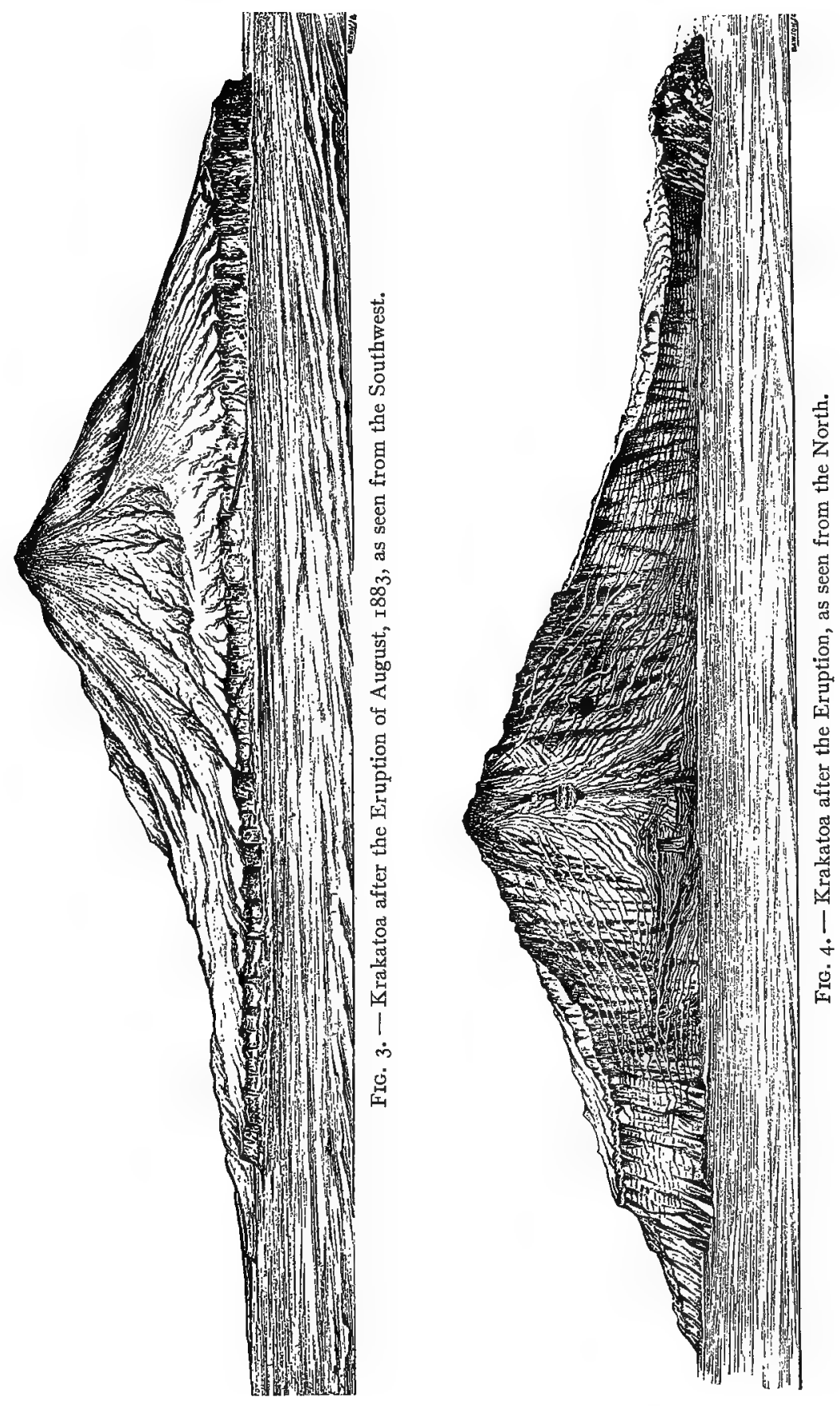
removed, and where the land had been 300 feet high a hollow was formed over a thousand feet below. the sea level. The northern part of the peak of Rakata was blown away, exposing a magnificent section, Figure 4, that has enabled geologists to study the internal structure of the volcano. The island Polish Hat disappeared entirely, and Lang and Verlaten were increased in size; the former slightly, the latter to about three times its former area; while a considerable addition was made to the height of both. The materials thrown from the volcano seem to have covered the sea bottom, within a radius of Io

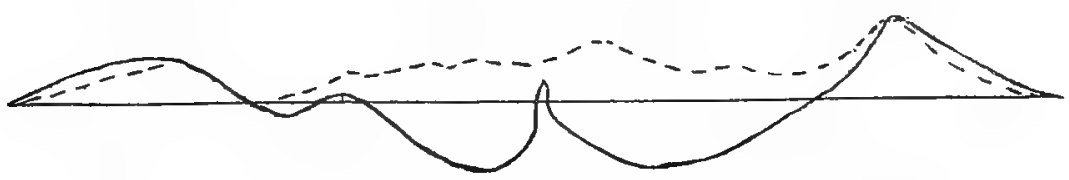

FIG. 5. - Outline of the Crater of Krakatoa as it is at the present time.

The broken line indicates the portions blown away during the eruption of August, $x 883$, and the changes in form of the flanks of the mountains by the fall of ejected materials upon them. From the "English Krakatoa."

or 12 miles, to a depth of from $\mathrm{x} 2$ to 60 feet. There is some doubt on this subject, however, as the waters surrounding the island had never been carefully sounded, and no accurate survey had been made. There is good reason to believe that the floor of the ocean was raised during the eruption, causing the great sea waves that will be referred to below.

Along a line about nine miles in length, extending westward from the great crater, a depression seems to have taken place which "was not improbably due to the opening of a fissure on the flanks of the submerged cone." During the eruption two small islands were formed, but both were soon reduced to shoals by the action of the waves. These islands are supposed to have been caused by parasitic cones that had arisen upon the northern flank of Rakata.

The watery vapor thrown into the air reached a height variously estimated from $I 2 \frac{1}{2}$ to $I 7$ and possibly 23 miles. On reaching the limit of its elevation, the mass spread itself and gave rise to the "pine-tree" appearance so often seen during the eruptions of Vesuvius. The surrounding country was enveloped in darkness for nearly twenty-four hours. The electrical phenomena accompanying the explosion were on a grand scale; the lightning darted through the dark clouds "like huge serpents," and "balls of fire" rested on the masts and yardarms of vessels 40 miles away. 
Volcanic dust rose to a great height and, floating away, gave rise to the wonderful optical phenomena noted throughout the civilized world. Some of the air waves generated caused the cracking of walls Ioo miles away, and others less violent, though of greater dimensions, travelled nearly four times round the earth. The terrible explosions gave rise to vast sea waves that stranded vessels, and devastated the shores of Sumatra and Java, causing the death of over 36,000 human beings. These explosions formed a notable feature of the eruption, and were probably due to the peculiar situation of the volcano. 'Owing to the proximity of the ocean, the water, at times, must have rushed in on the molten material. This would at first cause an evolution of steam and then a diminution of activity in the volcano, thus causing a "check," only to be followed by an outburst or "rally" of greater violence. In this way the alternations of the "check and rally" are supposed to have caused the unprecedented explosions.

The eruption continued until the 28 th or 29 th of August, with perhaps a slight outbreak on the Ioth of October of the same year. With this last sign of activity the subterranean forces seem to have exhausted their energy, and Krakatoa once more relapsed into a period of rest. Such is a general view of the eruption. We will now examine a few points a little more in detail.

\section{Materials Ejected}

The materials ejected from Krakatoa were lava, pumice, and volcanic dust. The lava presents two distinct forms, characterized as porphyritic obsidian and porphyritic pitchstone. Both contain the same crystalline elements which constitute about ro per cent of the rock; these crystalline elements are feldspar, pyroxenes, and magnetite scattered irregularly throughout the ground mass. In the obsidian the crystals of feldspar have perfectly sharp outlines, while in the pitchstone they are very much corroded, probably by the action of the fluid material which once surrounded them. The most striking difference between these two rocks is shown when they are placed in the flame of a blast-jet. The pitchstone is found to decrepitate and to undergo fusion with the greatest difficulty; the obsidian, on the other hand, fuses with comparative ease, and during the process forms "cauliflower-like masses" that are identical with the pumice thrown from the volcano. 
The loss suffered by the pitchstone during fusion is nil, while the obsidian loses from $I_{i}$ to 5 or 6 per cent of its weight. There is no doubt that the pumice ejected in such enormous quantities was formed by the expansion of the volatile gases contained in the obsidian. The condition in which the water and gases existed in the rock is a problem worthy of study.

The pumice contains the same crystals as the obsidian, and also little pieces of a black glass that have been shown to be identical with the pitchstone already referred to. Mr. Verbeek has calculated that the pumice and dust form 95 per cent of all the materials ejected. Some of the smaller pieces of pumice were thrown to a great height, and were carried by the wind some distance from the scene of eruption; the greater quantity, however, fell close to the volcano, covering the sea, in places, to such a depth as to effectually hinder the progress of vessels.

As the larger pieces of pumice fell back into the crater, they came in collision with others that were being thrown out, and in this way the pieces were broken, the finer particles forming the volcanic dust. The dust fell in great quantities in the vicinity, and samples have also been collected from many localities, some as far as a thousand miles from the island. Its exceeding fineness is shown by the fact that it penetrated everywhere, no box or watch being sufficiently tight to exclude it. The particles composing the dust have been separated and analyzed, and their optical properties investigated. The appearance and composition of the dust varies considerably; that found in the vicinity is heavier, darker in color, and more basic in composition than that gathered at a greater distance from Krakatoa. This difference is due to the heavy particles of magnetite pyroxene, and feldspar it contains.

The quantity of dust thrown into the air is not known, but it was probably much less than that formed at some previous eruptions. The work of trituration, however, continued about three months, and the last paroxysmal explosions of Krakatoa were altogether of exceptional violence and carried the finer particles high into the rarer regions of the atmosphere. From the data supplied by the vessels on which the dust fell, it is found to have covered an area of $1,100,000$ square miles. From the depth of the material it is calculated that the quantity of dust was equal in bulk to $3 \frac{1}{2}$ cubic miles, while the entire mass of ejected matter equalled about $4 \frac{1}{2}$ cubic miles. These figures, however, are estimates and probably only approximate the actual quantities. 


\section{Air Waves}

The air waves generated by the eruption were of three kinds: first, those sufficiently rapid to give rise to sound; second, larger waves that caused the breaking of windows and the cracking of walls, a hundred miles away, at Batavia; and third, those of still greater dimensions that travelled several times around the earth.

The sounds caused by the explosions were heard at Ceylon to the northwest; Perth and other stations in Australia to the southeast, and at Manila to the northeast. These places are situated close to a circle drawn from Krakatoa as a center with a radius of 30 degrees. To the west the sounds were carried by the trade-winds a much greater distance, and were heard at the island of Rodriguez, nearly 3000 English miles from the scene of eruption. This is interesting not only as being the most remote point at which the reports of the explosions were noticed, but as "the only instance on record of sounds having been heard at anything like so great a distance from the place of their origin." The area over which the sounds were recorded is about onethirteenth of the earth's surface.

The detonations in the vicinity of the volcano, although very violent, were not as loud as might be inferred from the distance at which they were heard, for the great rain of pumice and the heavy cloud of dust seem to have acted as a curtain through which the sound waves were unable to penetrate. At some places in the immediate neighborhood of the volcano sounds ceased to be heard after ten o'clock on the morning of August 27; although it is known that the explosions continued with great intensity after that time.

The great air wave that owed its origin to one of the last paroxysmal outbursts of Krakatoa was recorded on the barograms at the observatories scattered over the earth. Theoretically an air wave caused by a sudden explosion would spread in a circle around the earth till it reached a point go degrees from its origin; it would then travel onward, contracting as it advanced, till at the antipodes it would come to a focus and thence be reflected back to its starting-point, from whence it would once more travel to the antipodes and so on, till it gradually became lost. The barograms that have been collected show that the great wave passed seven times round the earth, four times from Krakatoa to the antipodes, and three times from the antipodes to 
Krakatoa, the barometers failing to record the fourth return of the wave.

The velocity of the wave varied from 674 to 726 English miles per hour, being very nearly equal to the velocity of sound in air at $50^{\circ}$ Fahrenheit, which is 757 miles. There is no direct evidence, however, that the great explosion producing the wave was accompanied by sounds sufficiently loud to be heard at any great distance. The time occupied by the wave passing around the earth was about 36 hours. The wave moving with the rotation of the earth traveled with a slightly greater velocity than that going in the opposite direction, viz. about 28 English miles per hour. This difference is supposed to be due to the winds that blow in a general westerly direction on the path followed by the wave. From the velocity of the wave it has been attempted to deduce the time of the great explosion, and the result agrees very closely with the record made by the gasometer at Batavia; for, when the wave passed over that place, the gasometer leaped from its well, and left a plain, though not very delicate, mark of the time. As thus determined the explosion occurred at 9 hours $5^{8}$ minutes, local time, on August 27 .

\section{Sea Waves}

No sea waves were caused by the eruption of Krakatoa during May, but on the morning of August 27 several small ones inundated the shores of Sumatra and Java, partially destroying the towns and villages, and causing the death of many of the inhabitants. The number and size of the waves that followed are not known, for the people had fled terror-stricken to the hills, and, surrounded by darkness, were but little fitted to note the changes about them. The most destructive waves followed the great explosions of the volcano some time after ten o'clock on the morning of August 27. From the data collected by Mr. Verbeek it has been calculated that the largest of the waves was about $5 \circ$ feet high before it reached the shore, although the traces it left on the land show that it rose yo feet above the sea level, and its height has been estimated by some as great as I 25 feet. The smaller waves are supposed to have been due to the sudden evolution of steam, caused by the contact of the sea and the molten lava, and by the fall of huge portions of the volcano. The origin of the great wave is an unsettled question. It has been assumed that 
during the eruption the volcano was raised bodily into the air and fell into the water, thus causing the wave; but this does not seem probable, as the mean period between crest and crest of the waves that followed the great one was two hours, and, further, there is no direct evidence supporting this view. It has also been suggested that if an enormous chasm had opened in the floor of the ocean the inward rush of the water would be sufficient to create the wave, - but in this case the fissure would have to be large enough to allow the water to flow into it for an hour with a rapidity sufficient to cause a great decrease in the level of the sea, and the first wave reaching the shore would be a negative one, which it was not. It is probable that the great wave was caused by an upheaval of the sea bottom, as it is known that the depth of water in the strait was decreased during the eruption, and this may have been due to an upheaval, the fall of ejected material, or to both causes. One of the waves, though not as high as the others, was longer, and probably traveled to Cape Horn, $75^{20}$ miles away, and possibly even as far as the English Channel, a distance of $I \dot{I}, 040$ miles. At such distances the height of the waves becomes very small, and hence their identification is rendered difficult.

The study of the velocity of seismic waves is of recent date. The first observations recorded were made by Professor W. P. Trowbridge at San Diego, Cal., in I855. The waves then noticed were found to have originated near Simoda, Japan, and were due to a submarine earthquake. Since then seismic waves have been found to be of frequent occurrence, although it is seldom that they can be traced to their starting-point. This is a matter of some interest, for the speed of the waves bears a constant relation to the depth of the water through which they travel. The velocity of those caused by the eruption of Krakatoa has been carefully calculated, for in this case the time and the place of origin were known. Some doubt is thrown on the result, however, as the same wave could not be positively identified at different places, owing to the rather inclosed position of Krakatoa, and hence the irregular path followed by the undulations; again, some of the tide gauges were situated up rivers and in estuaries where the direct effects of the wave would not be felt. It is quite certain, however, that the velocity of the waves from Krakatoa was less than that demanded by theory, as has also been observed in all previous cases. 


\section{Optical Phenomena}

No effect connected with the Krakatoa eruption has been so widely observed and speculated upon as the wonderful appearance the sky presented during the two years that followed the outbreak. Many theories have been offered to explain the phenomena, and while most of these agree that the dust formed in such enormous quantities during the eruption was the primary cause, some contend that the two were in no way connected. It is impossible to give here even a short account of these numerous theories, or the reasons why many have been rejected.

Meager accounts exist of similar phenomena accompanying previous great eruptions. During the 250 years, from 1500 to 1750 inclusive, there were 65 in which eruptions were recorded, nine of which were of exceptional magnitude, " and in three of these latter years Denmark was affected by appearances, two of which certainly were of the character of the afterglows, while the third is doubtful."

From I $75^{\circ}$ to I 886 the number of "years of eruption" was $9 \circ$; 25 of the outbreaks being of great magnitude, and of these I 6 appear to have been followed by "unusual redness in the sky, or brightness after sunset." Thus it will be seen that in the past like causes have produced like effects, and the lack of information on the subject is probably the fault of observers rather than the want of opportunity for observation. The optical effects of the eruption of Krakatoa, however, were exceptional, and had previous phenomena been so marked and so widely spread over the earth, they would have received more attention than the records imply. The effects of the outburst at Krakatoa were the unusual twilight glows, the blue, green, and other appearances of the sun, the sky haze, and the large corona round the sun and moon - all these phenomena were noticed first in the vicinity of Krakatoa.

The dust, after being ejected from the volcano, was carried westward around the earth at the equator, certainly twice, and "perhaps continuously." From this band the particles appear to have spread north and south, and so the phenomena were witnessed throughout the world. The twilight glows traveled westward at the rate of about 72 miles an hour, while the colored suns moved at the rate of about 70 miles. The unusual twilight glows are supposed to have been caused by the reflection of the sun's rays from the glassy particles of the powdered pumice that were suspended about I6 miles above the earth. 
The colored suns were probably due to the absorption of certain rays of light by the volcanic dust in the atmosphere. The large corona around the sun was first recorded by Mr. Bishop at Honolulu, on September 5, I883, and since that time it has generally been known as "Bishop's ring"; the halo around the moon was noticed in the tropics during the same month. These effects are referred to the lighter particles of dust in the atmosphere, for in April, I884, when most of the coarser material had settled by gravitation, and the twilight glows began to fade, the corona brightened, then gradually became fainter, and was last observed in June, I886, after which the sky resumed its normal appearance.

In conclusion, it may be said that the works on Krakatoa, referred to above, contain many charts, maps, and barograms, and in short form a complete record of all the phenomena caused by the eruption. These works are more valuable than if they contained only the results of the reports collected, for, by publishing the sources of information, opportunity is given to any one interested in the subject to study these, and thereby form his own conclusions. When other eruptions shall have been treated in the same manner, more light will be shed on some of the effects now slightly obscured, as the cause of the colors observed in the sky and the origin of the great sea waves. Although eruptions have occurred in the past, exceeding that of Krakatoa both in duration and in the quantity of material ejected, such a complete history of one has never been written till now. This is due in part to the spread of civilization over the earth, and hence the establishment of places of scientific observation. As the number of such observatories will continue to increase, it may be confidently predicted that the phenomena accompanying violent volcanic outbreaks in the future will be more closely observed and more widely recorded. 


\title{
PLANT NOTES FROM TEMISCOUATA COUNTY, CANADA ${ }^{1}$
}

\author{
BY JOHN I. NORTHROP
}

THE parish of Notre Dame du Lac lies on the western shore of Lake Temiscouata, Temiscouata County, Canada, about forty-eight miles from Rivière du Loup and thirty-one miles from Edmundston, N.B.

The surrounding country is for the most part rolling hills covered with the usual second growth of spruce, fir, larch, and birch. There are also groves of sugar maple and yellow birch, and on the lowland near the lake the balsam poplar, Populus balsamifera, grows luxuriantly. Populus tremuloides, Acer rubrum, A. spicatum, Prunus Pennsylvanicum, and Rhus typhina are common trees of the region.

The lake is about thirty miles long, and varies from three-quarters of a mile to two miles in width. The shore is in most places of slate, forming rocky points running into the lake, sometimes so abruptly as to make passing exceedingly difficult. In the crevices of the slate grow Lobelia Kalmii, Campanula rotundifolia, and Parnassia Caroliniana. Near the bank we find Potentilla fruticosa, Spircea salicifolia, and $M y$ rica gale.

Farther up Alnus viridis, Cornus stolonifera, and Viburnum Opulus form thickets guarded by the ever present Joe Pye Weed, Eupatorium purpureum. Here and there along the bank the berries of Pyrus sambucifolia add their bright color to the scene.

Along the roadside, where not shaded by trees, Artemisia vulgaris grows in undisturbed luxuriance, in company with the wild raspberry, Rubus strigosus, and Sambucus racemosa.

In the fields one misses the ubiquitous Chrysanthemum Leucanthemum, but its place is well filled by Anaphalis margaritacea and the Canada thistle. In many places the banks of the roadside are covered with the bunch berry, Cornus Canadensis, which the French Canadians

${ }^{1}$ Contributions from Herbarium of Columbia Coll. No. 3. Bull. Torrey Botanical Club, November, I887, pp. 230-238. 
aptly called "La rouge." Driving back from the lake, five or six ranges of hills are crossed in as many miles. In the valleys are lakes bordered with cedar swamps of Thuja occidentalis. The lakes are shallow and have a muddy bottom. Cassandra calyculata, Kalmia angustifolia, Ledum latifolium, are common on the borders.

The road from Notre Dame du Lac to Rivière du Loup runs partly through scattered farms and partly through woodland. The land, where cleared and neglected, is covered with a dense growth of Pteris aquilina and Epilobium spicatum.

From Rivière du Loup I drove to Cacouna, a distance of four miles down the St. Lawrence. The beach at Cacouna is rocky in some places and at others sandy. On the sand Cakile Americana, Lathyrus maritimus, Mertensia maritima, and Arenaria peploides were collected. On the rocky points Plantago maritima was found abundant.

The plants of the following list were mostly collected during the month of August, at Notre Dame du Lac. A few are from Grand Falls, N.B., where a stay of a few days was made.

Dr. N. L. Britton has kindly annotated the list, and many thanks are due him for his assistance and for suggestions in regard to nomenclature.

\section{CATALOGUE}

\section{RANUNCULACEÆ}

Thalictrum polygamum Muhl. Notre Dame du Lac. Anemone multifida Poir. Grand Falls. Anemone dichotoma L. Notre Dame du Lac. Anemone Virginiana L. Same locality. Ranunculus aquatilis L., var. trichophyllus Chaix. Same locality. Ranunculus acris L. Same locality. Ranunculus Pennsylvanicus L. Same locality. Actaa spicata L., var. rubra Michx. Same locality.

\section{SARRACENIACE $\nexists$}

Sarracenia purpurea L. Notre Dame du Lac.

\section{CRUCIFER $\approx$}

Raphanus sativus L. Cacouna.

Cakile Americana Nutt. Same locality. 


\section{VIOLARIE}

Viola blanda Willd. Notre Dame du Lac.

\section{CARYOPHYLLE}

Silene inflata Smith. Notre Dame du Lac.

Cerastium viscosum L. Same locality.

Stellaria media (L.) Smith. Same locality.

Arenaria peploides L. Cacouna.

Spergula arvensis L. Notre Dame du Lac.

\section{HYPERICINE $A$}

Hypericum mutilum $\mathrm{K}$. Notre Dame du Lac.

Hypericum Virginicum L. (Elodes Virginicả Nutt.) Same locality.

$$
\text { MALVACE } \$
$$

Malva moschata L. Notre Dame du Lac.

\section{GERANIACE $\mathbb{E}$}

Oxalis Acetosella L. Grand Falls.

Impatiens biflora Walter, $\Upsilon_{7} 88$ (I. fulva Nutt., I8I8). Notre Dame du Lac.

\section{ILICINE $Æ$}

Nemopanthes Canadensis (Michx.) DC. Notre Dame du Lac.

\section{SAPINDACE $\Psi$}

Acer rubrum L. Notre Dame du Lac.

Acer saccharinum Wang. Same locality. Acer spicatum Lam. Same locality.

\section{ANACARDIACE $\Phi$}

Rhus typhina L. Notre Dame du Lac.

\section{LEGUMINOS 平}

Trifolium agrarium L. Notre Dame du Lac.

Trifolium pratense L. Same locality. Also a white-flowered form. Trifolium repens $\mathrm{L}$. Same locality. 
Astragalus alpinus L. Grand Falls.

Vicia Cracca L. Notre Dame du Lac.

Lathyrus maritimus (L.) Bigelow. Cacouna.

\section{ROSACE}

Prunus Pennsylvanica L. Notre Dame du Lac.

Spirce salicifolia L. Same locality.

Rubus strigosus Michx. Grand Falls.

Rubus triflorus Richards. Notre Dame du Lac.

Geum strictum Ait. Same locality.

Fragaria vesca L. Grand Falls.

Fragaria Virginiana Duschene. Notre Dame du Lac.

Potentilla Anserina L. Temiscouata Lake.

Potentilla fruticosa L. Notre Dame du Lac.

Potentilla Norvegica L. Same locality.

Potentilla palustris (L.) Scop. Same locality.

Agrimonia Eupatoria L. Same locality.

Poterium Canadense L. Cacouna.

Rosa blanda Ait. Notre Dame du Lac.

Pyrus sambucifolia Cham. and Sch. Same locality.

\section{SAXIFRAGE $\nexists$}

Mitella nuda L. Grand Falls.

Parnassia Caroliniana Michx. Notre Dame du Lac.

Ribes lacustre Poir. Grand Falls.

\section{DROSERACEX}

Drosera rotundifolia L. Notre Dame du Lac.

\section{HALORAGE $\mathbb{E}$}

Hippuris vulgaris L. Dubé's Lake, Temiscouata.

ONAGRARI $x$

Epilobium spicatum Lam. Notre Dame du Lac.

Enothera biennis L. Cacouna.

Circea alpina L. Notre Dame du Lac. 


\section{PLANT NOTES FROM TEMISCOUATA COUNTY}

\section{UMBELLIFERæ}

Sanicula Marylandica L. Notre Dame du Lac. Conioselinum bipinnatum (Walter) Britton. ${ }^{1}$ Same locality.

\section{ARALIACE $A$}

Aralia hispida Vent. Notre Dame du Lac. Aralia nudicaulis L. Grand Falls. Aralia racemosa L. Same locality.

\section{CORNACE A}

Cornus canadensis L. Grand Falls.

Cornus stolonifera Michx. Same locality.

\section{CAPRIFOLIACE $\nexists$}

Sambucus racemosa $L$. Notre Dame du Lac.

Viburnum lantanoides Michx. ${ }^{2}$ Same locality.

Viburnum Opulus L. Same locality.

Linnoea borealis L. Same locality.

Diervilla trifida Mœnch. Same locality; also at Grand Falls, the latter a form with leaf-margins abundantly ciliate.

\section{RUBIACE $\mathbb{E}$}

Galium trifidum L., var. pusillum Gray. Notre Dame du Lac. Galium triflorum Michx. Grand Falls.

\section{COMPOSIT 压}

Eupatorium ageratoides L. Notre Dame du Lac.

Eupatorium purpureum L.

Solidago bicolor L., var. concolor Torr. and Gray. Same locality. Solidago macrophylla Pursh. Same locality.

Solidago neglecta T. and G. Grand Falls.

${ }^{1}$ Conioselinum bipinnatum (Walter, "Flor. Car.," p. xI5, under $A$ pium, I788; Selinum Canadense Michx., I803). I am following Coulter and Rose in keeping up the genus Conioselinum. - N. L. B.

${ }^{2}$ If the $V$. alnifolia of Marshall is this plant, the name has priority; it is referred to V. lantanoides by Dr. Gray, in "Syn. Flor.," while De Candolle, "Prodr.," IV, p. 328, refers it to $V$. molle Michx. - N. L. B. 


\section{PLANT NOTES FROM TEMISCOUATA COUNTY 245}

Solidago serotina Ait. Notre Dame du Lac.

Erigeron annuus Pers. Same locality.

Erigeron Canadensis L. Same locality.

Erigeron hyssopifolius Michx. Grand Falls.

Erigeron strigosus Muhl. Notre Dame du Lac.

Aster diffusus Ait. Same locality.

Aster macrophyllus L. Same locality.

Aster puniceus L. Same locality.

Aster umbellatus Mill. Same locality.

Anaphalis margaritacea (L.), Benth. and Hook. Same locality.

Achillaa Millefolium L. Same locality.

Chrysanthemum Leucanthemum L. Same locality.

Artemisia caudata L. Grand Falls.

Artemisia vulgaris L. Notre Dame du Lac.

Senecio aureus L., var. Balsamite T. and G. Grand Falls.

Cnicus arvensis (L.) Hoffm. Notre Dame du Lac.

Arctium Lappa L. Same locality.

Hieracium Canadense Michx. Same locality.

Hieracium scabrum Michx. Same locality.

Prenanthes altissima L. Same locality.

Prenanthes serpentaria Pursh. Grand Falls.

Lactuca leucophaa (Willd.) Gray. Notre Dame du Lac.

Sonchus arvensis L. Cacouna.

\section{CAMPANULACE AE}

Lobelia Kalmii L. Notre Dame du Lac.

Campanula rotundifolia L. Grand Falls.

\section{VACCINIACE $A$}

Vaccinium Canadense Kalm. Notre Dame du Lac.

Vaccinium Pennsylvanicum Lam. Same locality.

\section{ERICACE 歼}

Cassandra calyculata (L.) Don. Notre Dame du Lac.

Andromeda Polifolia L. Same locality.

Kalmia angustifolia L. Same locality.

Ledum latifolium Ait. Same locality.

Chimaphila umbellata (L.) Nutt. 
MONOTROPEA

Monotropa uniflora L. Notre Dame du Lac.

OLEACE正

Fraxinus viridis Michx. A form with pubescent branchlets.

GENTIANE 2

Halenia deflexa (Smith) Griseb. Notre Dame du Lac.

BORAGINE $\Phi$

Mertensia maritima (L.), Gray. Cacouna.

Myosotis laxa Lehm. Notre Dame du Lac.

SCROPHULARTNE压

Linaria vulgaris Mill. Notre Dame du Lac.

Chelone glabra L. Same locality.

Veronica Americana Schwein. Same locality.

Castilleia pallida Kunth. Grand Falls.

Euphrasia officinalis L. Notre Dame du Lac.

Rhinanthus Crista-Galli L. Same locality.

\section{LENTIBULARIE $\mathbb{E}$}

Utricularia vulgaris L. Dubé's Lake, Temiscouata.

Utricularia intermedia Hayne. Same locality.

\section{LABIAT $\mathbb{A}$}

Mentha Canadensis L., var. glabrata Benth. Notre Dame du Lac. Nepeta Cataria L. Same locality.

Brunella vulgaris L. Grand Falls and Notre Dame du Lac.

Scutellaria galericulata L. Notre Dame du Lac.

Scutellaria lateriflora L. Same locality.

Stachys palustris L. Same locality.

Galeopsis Tetrahit L. Same locality.

\section{PLANTAGINE A}

Plantago maritima L. Cacouna. 


\section{CHENOPODIACE 左}

Atriplex patula L., var. hastata Gray. Cacouna.

\section{POLYGONACE $\mathbb{A}$}

Polygonum aviculare L. Notre Dame du Lac.

Polygonum Hydropiper L. Same locality.

Polygonum lapathifolium Ait., var. incanum Koch. Same locality. Rumex Acetosella L. Grand Falls.

Rumex salicifolius Weinm. Cacouna.

Rumex Brittanicus L. . Notre Dame du Lac.

EUPHORBIACE $\&$

Euphorbia Helioscopia L. Notre Dame du Lac.

$$
\text { MYRICACE } A E
$$

Myrica Gale L. Notre Dame du Lac.

\section{CUPULIFER $\mathbb{A}$}

Betula papyracea Ait. Grand Falls. Alnus viridis DC. Notre Dame du Lac. Corylus rostrata Ait. Grand Falls.

\section{SALICINE㭱}

Salix discolor Muhl. Notre Dame du Lac. Salix humilis Marsh. Same locality. Salix lucida Muhl. Same locality. Populus balsamifera L. Same locality. Populus tremuloides Michx. Grand Falls.

\section{ORCHIDE正}

Spiranthes Romanzoffiana Cham. Notre Dame du Lac. Habenaria hyperborea R. Br. Same locality. Habenaria psycodes (L.) Gray. Same locality.

IRIDE正

Iris versicolor L. Notre Dame du Lac. 


\section{IILIACE $Æ$}

Streptopus amplexicaulis (L.) DC. Notre Dame du Lac.

Streptopus roseus Michx. Same locality.

Smilacina trifolia (L.) Desf. Same locality.

Maianthemum Canadense Desf. Same locality.

Tofieldia glutinosa Willd. A form with pedicels four to six lines long in fruit. Grand Falls.

Clintonia borealis (Ker.) Raf. Notre Dame du Lac.

\section{JUNCACE}

Juncus effusus L. Notre Dame du Lac.

Juncus filiformis $\mathrm{L}$. Same locality.

J. Canadensis Gay, var. coarctatus Engelm. Same locality.

\section{TYPHACE $\nexists$}

Sparganium simplex Huds., var. Nuttallii Engelm. (?) Same locality.

\section{ALISMACE $\mathbb{E}$}

Sagittaria variabilis Engelm., var. hastata Engelm. Notre Dame du Lac.

\section{NAIADACE $\mathbb{E}$}

Potamogeton natans L. Same locality.

Potamogeton Pennsylvanicus Cham. ( $P$. Claytonii Tuckerm.), fide Morong.

\section{ERIOCAULE I}

Eriocaulon septangulare With. Dubé's Lake, Temiscouata.

\section{CYPERACE $A$}

Carex rostrata With., var. utriculata Bailey. Notre Dame du Lac. Carex hystricina Muhl. Same locality.

Carex flava L. Same locality.

Carex scoparia Schk. Same locality.

GRAMINE $A$

Spartina cynosuroides Willd. Notre Dame du Lac. Deyeuxia Canadensis (Beauv.) Hook. Same locality. Glyceria Canadensis (Michx.) Trin. Same locality. Elymus mollis Trin. Cacouna. 


\title{
PLANT NOTES FROM TEMISCOUATA COUNTY 249
}

\author{
CONIFER $\Psi$
}

Thuja occidentalis L. Grand Falls.

EQUISETACE

Equisetum sylvaticum L. Notre Dame du Lac.

FILICES

Asplenium Filix-fomina (Swartz) Bernh. Notre Dame du Lac. Phegopteris polypodioides Feé. Same locality

Phegopteris Dryopteris (L.) Feé. Same locality. Aspidium spinulosum Swartz. Same locality. Cystopteris bulbifera (Swartz) Bernh. Grand Falls. Aspidium marginale Swartz. Same locality. Osmunda Claytoniana L. Notre Dame du Lac.

$$
\text { OPHIOGLOSSACE }
$$

Botrychium Virginianum Swartz. Notre Dame du Lac.

\section{LYCOPODIACE $\mathbb{E}$}

Lycopodium clavatum L. Notre Dame du Lac. Lycopodium complanatum $\mathrm{L}$. Same locality. Lycopodium dendroideum Michx. Same locality. 


\section{PLANT NOTES FROM TADOUSAC AND TEMISCOUATA COUNTY, CANADA ${ }^{1}$}

\section{By JoHN I. AND Alice R. Northrop}

THE little village of Tadousac is beautifully situated at the junction of the Saguenay and the St. Lawrence. The latter river here forms quite a deep bay, on the curving shores of which stands the main part of the village, while on the jutting rocky point that separates the bay from the mouth of the Saguenay, are the picturesque cottages of the French fishermen and half-breeds. Just south of the village the banks become very steep and here, far above the present beach, are two, and in some places three, very fine terraces, stretching around the point of the bay and for some distance down the St. Lawrence. Back of all rise the lofty hills of the Saguenay. Our first walk was out on the headland at the mouth of the latter river, and here, at the level of the sea, we found many of the alpine plants of Mt. Washington; among these were Potentilla tridentata, Euphrasia officinalis, and Vaccinium Vitis-Idaa. Great mats of Empetrum nigrum grew on the rocky banks and beautiful Campanulas nodded from the crevices. We were interested in observing that here Campanula rotundifolia bore only a single flower at the summit, and resembled but slightly the large and many-flowered plants, two feet in height, that we had collected in Crawford Notch, and also very different apparently from the little blue-bells, three inches high, that grow near the Lake of the Clouds on Mt. Washington, and bear but a single erect flower, of a very dark blue color.

We found much the same difference in the forms of Euphrasia officinalis. We had first collected it a few weeks previous, near Oakes' Gulf on Mt. Washington, and there, though mature, it was so tiny that in order to find it, we had literally to get down on our hands and knees, and go over the ground inch by inch. At Tadousac we collected the usual small bushy Canadian form, and a week or two later, at Lake

${ }^{1}$ Bull. Torrey Botanical Club, Vol. XVII, No. 2, February, I8go. 
Temiscouata, found some specimens about 8 inches high. Besides this alpine flora, there were many maritime plants. Plantago maritima and Triglochin maritimum were common, Tissa salina grew on the tide flats, and Lathyrus maritimus over the rocks on the beach. But most beautiful of all were the great spreading clusters of Mertensia maritima, with its graceful trailing branches, glaucous foliage, and showy blue flowers.

Higher up on the rocks were great patches of Kalmia angustifolia, making masses of pink bloom; with these grew Ledum latifolium and Cassandra calyculata, both in fruit, while shading these tangled thickets were Pinus Banksiana, the white spruce, and the black spruce. Trailing over the rocks we found Juniperus Sabina, var. procumbens, in fruit, and the prostrate variety alpina of $J$. communis.

The yellow blossoms and curious inflated pods of Rhinanthus Crista-galli were common near the shore, and in the wet grassy spots Microstylis unifolia grew plentifully. Along the Saguenay we collected Ranunculus Cymbalaria, and in the crevices of the rock Aspidium fragrans was found growing in large tufts, still holding last year's leaves, and Corallorhiza innata. Here we also collected Comandra livida and Goodyera repens.

On the border of a small pond near Tadousac, Polygonum amphibium was found, and in the bogs near the shore we saw Eriophorum gracile, and with it the purple-flowered Potentilla palustris; also Calla palustris, but the flowers had already gone, and we could only get the fruit. Although it was the last week in July, we noticed that the little birches on the hillsides near Tadousac had begun to turn yellow, showing that the brief Northern summer was already on the wane.

A sail of three hours brought us to Rivière du Loup, and the next morning we botanized along the banks of the rapid-flowing stream that gives the town its name. In one place it makes a plunge of about 40 feet over the edges of the dark slaty rock which forms its bed, and here under the hemlocks we found Moneses uniflora, the bright blue berries of Clintonia, Coptis trifolia, and Halenia deflexa.

Our train left Rivière du Loup about noon, and we were soon speeding towards Lake Temiscouata, some fifty miles to the southeast. At first poplars, birches, and spruces were plenty, but as we neared the lake, we passed through great swamps of Thuja occidentalis, some of the trees being the largest we had ever seen. In the cleared places were 
large patches of Cnicus arvensis, Epilobium spicatum, and great masses of the gorgeous yellow heads of Sonchus arvensis, while in places Vicia Cracca covered the grass and low shrubs with a mantle of blue. After a ride of nearly three hours, we alighted at our destination, the little village of Notre Dame du Lac, prettily situated on the curving shore of Lake Temiscouata.

Two lists of plants from this region have already appeared in the Bulletin, the first by John I. Northrop, in November, I887, the second by Henry M. Ami, in May, r888.

On my previous visit, in one place near the shore, I collected an exotic labiate, which was not determined as the specimen was in fruit, but this year we found the same species, now evidently well established and holding its own in a dense growth of Galeopsis Tetrahit and Amarantus. It has curious one-sided spikes of blue flowers, and a peculiar lemon-like odor. We sent some specimens to Dr. Britton, who wrote in reply that it was Elsholtzia cristata, a native of Siberia, and belonged near our genus Collinsonia. We found it growing in a clearing near a mill, and there is no doubt but that it has been introduced. Still, there are no records of its ever being cultivated, and how it reached this out-of-the-way spot is a mystery.

Near by on the banks of a brook Listera convallarioides grew abundantly, and on the hillside above we found a few specimens of Pyrola chlorantha. Great beds of Cornus Canadensis grew here, as almost everywhere in Canada, and we noted that here, as elsewhere, we could not find a single four-leaved plant that bore a flower. We had been struck with this fact while botanizing in the White Mountains, and had made it a special point of observation all summer, but out of the hundreds of plants which we examined not one exception did we find to this rule.

One day we took our canoe and paddled some three miles down the opposite shore of the lake and here, growing among the moss along a little brook, we found the rare Selaginella spinosa, looking very much like a delicate Lycopodium. Farther up the lake on the way to $\mathrm{Mt}$. Wissick we found a number of plants of Equisetum littorale. The specimens have since been carefully examined and compared with those so named by Dr. Morong, and they are undoubtedly the same species. On our way to Mt. Wissick we passed over a shallow portion of the lake, and a better place to collect water plants could not readily be 
found. The bottom was in some places gravelly and in others of sandy clay. The water was beautifully clear, but two or three feet in depth. We found here five Potamogetons: $P$. pectinatus, $P$. gramineus, $P$. amplifolius, $P$. natans, and $P$. perfoliatus, the delicate Ranunculus aquatilis, var. trichophyllos, and two species of Chara. Here and there the spikes of the great bulrush, Scirpus lacustris, rose six or seven feet above the surface of the water.

Most beautiful of all were the Myriophyllums; one of these, verticillatum, grew near our camping place in great masses, and we could look down into the clear water and trace the long, feathery, unbranched stems until they reached the sand, some seven or eight feet below.

Another species, more slender and growing in much shallower water, we have since determined as Myriophyllum alterniflorum. Attention has been called to this interesting species by Dr. Morong in a previous number of the Bulletin (xiv. 5I), where he states that it has been found in Lake Memphremagog, Canada, by Mr. J. R. Churchill, but previously had been collected no nearer to us than Greenland.

Well pleased with our morning's spoils, we paddled on a mile or so farther, until we found a good camping place, when we disembarked and soon started for the top of la grosse montagne.

Our trail led up through the usual growth of balsam, white spruce, and Betula papyrifera; here and there the ledges were luxuriously carpeted with Cladonia rangeriferina. Higher up we found dozens of specimens of Habenaria Hookeriana, and even more abundant was Corallorhiza multiflora. We also found some few spikes of $C$. innata. About $55^{\circ}$ feet above the lake we found some plants of Epigaa repens (the first we had seen in Canada) surrounded by Vaccinium Pennsylvanicum, Kalmia angustifolia, and Ledum latifolium, and shaded by black and white spruces. Among the crannies of the upper ledges we found Woodsia Ilvensis, W. hyperborea, Pellea gracilis, and Aspidium fragrans.

The summit was shaded by very fine specimens of the red pine, Pinus resinosa. The next day we worked up our plants, collected some fossils from the ledges at the foot of the mountain, and later on in the afternoon started back for Notre Dame du Lac. The few remaining days we spent there were devoted to grasses and sedges there was not a very great variety of either, however, and their names will be found in the appended list. 
The following list contains the plants collected that have not been mentioned in the former lists. Unless otherwise stated the locality is in the vicinity of Notre Dame du Lac.

Ranunculus reptans.

Coptis trifolia.

Nymphosa advena.

Nasturtium palustre.

Silene noctiflora.

Hypericum ellipticum.

Trifolium hybridum.

Astragalus oroboides,

var. Americanus.

Amelanchier Canadensis,

var. rotundifolia.

Chrysosplenium Americanum.

Ribes prostratum.

Myriophyllum verticillatum.

Myriophyllum alterniflorum.

Osmorrhiza brevistylis.

Heracleum lanatum.

Carum Carui.

Galium asprellum.

Erigeron Philadelphicum.

Gnaphalium uliginosum.

Lobelia Dortmanna.

Epigaa repens, Mt. Wissick.

Pyrola elliptica.

Pyrola rotundifolia.

Pyrola chlorantha.

Hypopitys Monotropa.

Fraxinus sambucifolia.

Veronica serpyllifolia.

Veronica scutellata.

Verbascum Thapsus.

Mentha sativa.

Elscholtzia cristata.

A pocynum androsamifolium.

Chenopodium capitatum.

Fagus ferruginea.

Polypodium vulgare.

Pellaca gracilis.

Aspidium fragrans.

Woodsia Ilvensis, Mt. Wissick.

Woodsia hyperborea, Mt. Wissick.
Listera convallariodes.

Microstylis unifolia.

Corallorhiza innata.

Goodyera repens.

Habenaria orbiculata.

Trillium erectum.

Juncus nodosus.

Juncus tenuis.

Juncus bufonius.

Potamogeton amplifolius.

Potamogeton gramineus.

Potamogeton perfoliatus.

Potamogeton pectinatus.

Carex intumescens.

Carex retrorsa.

Carex stipata.

Carex tentaculata.

Scirpus atrovirens.

Eriophorum cyperinum.

Dulichium spathaceum.

Eleocharis palustris.

Eleocharis ovata.

Phleum pratense.

Agrostis alba.

Agrostis hiemalis.

Deschampsia caspitosa.

Poa serotina.

Bromus ciliatus.

Agropyrum repens.

Taxus baccata, var. Canadensis.

Abies Mariana.

Equisetum arvense.

Equiselum limosum.

Equisetum littorale.

Equisetum pratense.

Equisetum scirpoides.

Botrychium Virginicum, var. gracile,

Mt. Wissick.

Lycopodium annotinum.

L. lucidulum.

Selaginella spinosa. 


\title{
NOTES ON THE PLANT DISTRIBUTION OF MT. WASHINGTON, N.H.
}

\author{
By JoHn I. AND Alice R. NoRthrop
}

In the course of a week's botanizing on the summit of Mt. Washington in the early summer of I889 (July 2-9), a fairly complete collection of its flora was made, largely with the view of ascertaining the distribution of the plants in relation to altitude. The respective elevations were determined by means of an aneroid barometer. The following pages give a brief résumé of the results obtained.

The base of the mountain, where the cog railway begins, was made out to be approximately 2500 feet. Here the flora was about the same as in the valley. During the first five hundred feet of elevation the mountain ash (Pyrus sitchensis (Roem.) Piper), Acer spicatum Lam., Acer pennsylvanicum L., Prunus pennsylvanica L. f., Picea mariana (Mill.) B. S. P., and Abies balsamea (L.) Mill. were noted. Of these the striped maple (Acer pennsylvanicum) was not seen above 3000 feet of elevation, Betula lutea Mich. f., and Acer spicatum were infrequent in the second five hundred feet and did not reach the 3500 limit, while Prunus pennsylvanica was abundant up to 3500 , but was entirely wanting above 4000 feet altitude. Pyrus sitchensis, at first very plentiful, was much less common at 4000 feet, and at 4300 feet was noted only as a straggling bush. A single specimen was found at an altitude of 5700 feet near the trail leading into Tuckerman's Ravine. Betula alba L., var. papyrifera, was abundant from 3500 to 4000 feet, but was much less frequently met with beyond the 4300 limit, and higher up was replaced by the variety minor (Tuckerm.) Fernald. This, as a low straggling bush, held its own far above the timber line, while about the summit it in turn gave way to Betula glandulosa Michx.

The two conifers, Picea mariana and Abies balsamea, were conspicuous throughout, and from 4300 feet upward were almost the only woody plants to be found. They grew as stunted shrubs, two or three feet in height, at an altitude of 5000 feet, and even above that a 
few storm-beaten specimens, hardly a foot in height, were occasionally seen. One plant, about fifteen inches in height, was noted in a sheltered spot near the Crawford bridle-path, at an altitude of 6000 feet. Near the Lake of the Clouds, at about 5000 feet, clumps of the black spruce were found with stems three or four inches in diameter, but with the branches pressed flat against the ground. As a rule, however, the balsam was the first to be noted as we descended from the summit.

Various trips were made to the Great gulf or Gulf of Mexico, Oakes' gulf, Tuckerman's Ravine, the Lake of the Clouds, Bigelow's lawn, and the alpine garden. The plant altitudes were carefully noted on each descent, and the succession of flowers was almost invariably the same. On the very summit, 6300 feet, a thrifty specimen of that hardy traveler, the dandelion, was in full bloom and apparently as much at home as on the roadsides several thousand feet below. Among the' rightful owners of the rocky soil the following always headed the lists: the Greenland sandwort (Arenaria grcenlandica (Retz) Spreng), the mountain cranberry (Vaccinium Vitis-Idca L., var. minus Lodd), and Potentilla tridentata Ait. Growing with these on some parts of the summit were the alpine goldenrod (Solidago Cutleri Fernald) and Diapensia lapponica L. The convex clumps of the latter were plentiful in some places, but it was already in fruit, and only after much searching were one or two belated blossoms found. Within a radius of a few hundred feet from the summit were noted the yellow mountain avens (Geum Peckii Pursh.), common in the grassy places, the two bilberries (Vaccinium ccespitosum Michx. and Vaccinium uliginosum L.), Silene acaulis L., the alpine azalea (Loiseleuria procumbens (L.) Desv.), and the Lapland rose bay (Rhododendron lapponicum (L.) Wahlenb.), the latter in fruit only. Although it was late for them, we were fortunate in discovering two or three patches of the mountain heath (Phyllodoce corulea (L.) Bab.), still covered with the purple bells and clinging to the ledges. Cassiope hypnoides (L.) Don. was also found in bloom in a few places. On or very near the summit we also collected the sedges, Carex capitata L., Carex rigida Good, var. Bigelowii (Torr.) Tuck., Carex capillaris L., and the wood-rush (Luzula spicata (L.) DC.).

All the plants above mentioned were found growing in dry places among the rocks of the cone, while the following were collected in or along the brooklets which run down the sides of the Great gulf, 
Tuckerman's Ravine, and Oakes gulf. The vegetation was most luxuriant about the streamlets that trickle down the slope at the head of Tuckerman's Ravine. Here at an elevation of 5300 or 5400 feet the bright green plaited leaves of Veratrum viride Ait. and the tall stems and large umbels of the cow-parsnip (Heracleum lanatum Michx.) first caught the eye. The two species of twisted-stalk (Streptopus amplexifolius (L.) DC. and S. roseus Michx.) were both abundant; while Castilleja pallida L., var. septentrionalis (Lindl.) Gray, raised its creamy blossoms everywhere. A little farther down the fragrant spikes of Habenaria dilitata (Pursh.) Gray were found in the shade of the Veratrum. Spirca salicifolia L., the meadow sweet, was also noted here. Of the smaller plants the yellow rays of the arnica (Arnica mollis Hook., var. petiolaris Fernald) and the bright blue flowers of Veronica alpina L., var. unalaschensis $\mathrm{C}$. and S., were conspicuous. In moist grassy places everywhere on the mountain Houstonia carulea grew luxuriantly, although it belied its name by bearing pure white flowers without a trace of blue. (It is now known as variety Faxanorum Rose and Moore.) The sleeping position of this plant was interesting. The flowers were partly closed and bent down on their slender stems, all turning in the same direction, to the northeast in all the plants we examined. The Northern chickweed (Stellaria borealis Bigel), Epilobium Hornemanni Reichenb., Polygonum viviparum L., the mountain sorrel (Oxyria digyna (L.) Hill), and the little alpine violet (Viola palustris L.) were collected in or along the brooks, as were also the less common alpine cress (Cardamine bellidifolia L., var. laxa Lange) and the rare Saxifraga rivularis L.

Of the plants usually found at a much lower altitude we noted the gold-thread (Coptis trifolia (L.) Salisb.) still in bloom, Ranunculus abortivus L., Rubus triflorus Richards, Trientalis americana (Pers.) Pursh., Ribes lacustre (Pers.) Poor, Ledum grcenlandicum Oeder., and Clintonia borealis (Ait.) Raf. In all our descents Aspidium spinulosum (O. P. Müller) Sw. was the first fern to make its appearance at an altitude of over 5000 feet, Phegopteris polypodioides Fee. the second, and Asplenium Filix-fremina (L.) Bernh. the third.

The conditions seemed very similar on all parts of the summit, yet many of the alpine and subalpine species were very locally distributed. For example, among the willows, Salix herbacea L. was exceedingly common in the Great gulf, but was only represented elsewhere by a 
very few specimens in Oakes gulf and the alpine garden. On the other hand, Salix argyrocarpa Anders., was common in Tuckerman's Ravine and elsewhere, but none were found in the Great gulf, while Salix Uva-ursi Pursh. was plentiful throughout. In Tuckerman's Ravine Salix argyrocarpa and Salix phylicifolia L. grew side by side and with them a third, a hybrid between the other two. This had been discovered by Mr. Edwin Faxon, the well-known botanist and collector, whom we had the pleasure of meeting on his annual visit to the mountain.

Further instances of local distribution were that of Saxifraga rivularis which we believe has never been collected elsewhere than the one little brook in which we found it, and Gnaphalium supinum L., which is still more rare, growing only, so far as we were able to discover, in two small stations, each but a few feet in extent. We were fortunate in finding specimens of this alpine cudweed, although they were only a little over an inch in height.

In company with Mr. Faxon, we found in the alpine garden after some search a small patch of the alpine bearberry (Arctostaphylos alpina (L.) Spreng.), where he remembered having seen it some years before. Silene acaulis was found in but one locality near the summit, although quite plentiful there, and Potentilla Robbinsiana Oakes was noted only near the Lake of the Clouds. The little eyebright (Euphrasia Oakesii Wettst.) was met with in only one locality of small extent which was pointed out to us by Mr. Faxon. Again Prenanthes nana (Bigel) Torr. seemed to be entirely confined to one side of the mountain, and Prenanthes Bootii (DC.) Gray to the other. The cloudberry (Rubus Chamamorus L.) was collected on the summit of neighboring Mt. Clinton, but not on Mt. Washington itself. There seems to be no reason why the distribution of these plants should be so restricted, as in many instances the conditions are apparently favorable to their spread, but perhaps this remnant of a more Northern flora finds it sufficiently difficult to hold its own. During the week spent on the mountain sixty species of plants in flower were collected above an altitude of 4600 or 4700 feet. These represented twenty-three orders and forty-six genera, to which are to be added twenty additional species, some of which were in fruit, others in leaf only, making a total of eighty species growing above the altitude mentioned. 


\section{A STUDY OF THE HISTOLOGY OF THE STEM OF THE WAX PLANT, HOYA CARNOSA (L.) R. Br.}

\section{By JOHN I. NORTHROP}

IN the fall of the year I886 Dr. N. L. Britton suggested that I study the anatomy of the wax plant, Hoya carnosa, as it appeared to be hitherto undescribed and possessed interesting peculiarities of structure.

From that time to the present $\mathrm{I}$ have had the investigation in hand and the following pages present the result.

\section{History}

I have been unable to find any account of the discovery of the wax plant or mention of the name of the person who first collected it. Linnæus named it Asclepias carnosa; and Loureiro, under the name of Stapelia Chinensis, describes a plant which he thinks may be the same as that called Asclepias carnosa by Linnæus.

In I809 Robert Brown divided the order Apocinee, retaining the old name for one part and calling the other the Asclepiadece. In the latter order he named for Thomas Hoy, an "intelligent and successful cultivator," for some time gardener to the Duke of Northumberland, the genus Hoya, in which he placed the Asclepias carnosa of Linnæus and the Stapelia Chinensis of Loureiro, uniting them under the name the plant has since borne, Hoya carnosa (L.), R. Br.

Brown considered the wax plant the type of the genus, and states that it "probably includes several species which can only be determined from living specimens." As its habitat he gives tropical Asia and New Holland.

De Candolle, in his "Prodromus," gives for localities "Eastern India, tropical Asia, around Canton" (quoting Loureiro), and questions New Holland. George Bentham, in the "Flora Hongkongensis," for localities gives "Mount Victoria, Champion; also in adjoining continent, not known for certain out of South China, but probably 
extending to Sikkam, as one specimen was found, without any indication of its precise station, among Dr. Hooker's collection from that country."

The plant was described by Schrank as Schollia carnosa, and by Jacquin fils as S. crassifolia; these two names are probably both subsequent to that given by Brown. Miller, in the "Gardener's Dictionary," calls the plant the "Fleshy-leaved Swallow Wort." Loudon, in the "Hortus Britannicus," states that it was introduced into Britain in 1802 ; and in the "Encyclopedia of Plants" that "one or two plants placed when in flower in a vinery of ripe grapes will entice the wasps from eating the ripe fruit." In the Botanischer Jahresbericht, I88I, it is stated that the honey of Hoya kills bees.

Darwin, in his investigations on climbing plants, speaking of the gradation of twining plants to simple root climbers, mentions that Bignonia. Tweedyana and Hoya carnosa revolve and twine, but likewise emit rootlets which adhere to any fitting surface. The plants I have had showed no aërial roots, with the exception of a large one that had been trained over a wooden support, and developed a number of rootlets where the frame and the plant had been for a long time in contact.

\section{General Description of the Stem}

$$
\text { Pl. I, Fig. I. Pl. II, Fig. } 4
$$

For convenience in description, the stem of Hoya carnosa may be divided into the following zones of tissues, which are best seen in a section about $4 \mathrm{~mm}$. in diameter. Proceeding from the periphery to the center we have:-

I. The epidermis with its hairs, stomata, etc., composed of one row of polygonal cells with the thick cuticle on the outside. The lateral walls are much thinner, and the cell is completed by one or two walls which are contiguous with the next row of cork cells.

2. The cork, composed of one or more rows of rectangular cells.

3. A broad band of parenchyma containing many intercellular spaces.

4. A ring of sclerotic cells, called by Davids the sclerotic girdle, in a stem of the above size, generally consisting of two rows of cells, which are lignified, and resemble closely the sclerotic cells of the pear.

5. A broad band of parenchyma, similar to the third ring, 
containing the bast fibers which are scattered in bundles just within the sclerotic girdle.

6. The cambium'composed of thin-walled cells.

7. The wood containing the medullary rays, ducts, etc.

8. The pith made up of parenchyma with intercellular spaces.

9. A few sclerotic cells in the center of the pith similar to those of the girdle, but in a section of a young stem, slightly larger, being circular in outline; while those of the girdle are compressed, having their shorter axis on the radial line.

A section corresponding to the above description may serve as a type with which to compare an older and a younger stem. In the younger portion of the stem (the first internode) the most noticeable features are the absence of the sclerotic girdle and cork cells, and the increased number of hairs and stomata.

In the older portions of the stem the principal changes consist in the relative space occupied by the different tissues and their modifications. For example, in a section of a stem to $\mathrm{mm}$. in diameter we find the epidermis missing, and the cork, which is popularly known as "bark," beginning to part in places. The space between the sclerotic girdle and the cork has grown much narrower, and is dotted here and there with many sclerotic cells like those of the pith. The sclerotic girdle is composed of cells irregular in shape, and what we may call - their tangential diameter is now much greater than their diameter measured on the radius of the stem. The ring of parenchyma containing the bast has grown narrower and now contains sclerotic cells here and there.

The wood has increased and occupies a proportionately much greater part of the stem. It is very irregular in outline and is often penetrated by wedge-shaped masses of parenchyma. The ducts are prominent owing to their increased number. The pith is contracted, and in its center is a mass of sclerotic cells. Just within the ring of wood will be noticed collections of small cells forming well-marked patches around the pith. These I have been unable to find mentioned in any work at my command, unless they are what Davids, in his "Ueber die Milchzellen der Euphorbiaceen, etc.," calls soft bast bundles ("Weichbast bundel"). Crystals and milk cells will be considered in treating the different rings of tissues. 


\section{EPIDERMIS}

\section{Pl. I}

If the stem of a young plant is examined, it will be found covered with a growth of velvety hairs, and numerous adventitious buds will be seen between the internodes. Portions of the epidermis may be easily obtained by drying a piece of stem that has been in alcohol, or they may readily be pulled off from an older part of the plant. It is composed of cells varying from I $_{5} \mu$ to Ioo $\mu$ in length, and from Io to $3 \circ \mu$ in width, with their greatest diameter parallel to the axis of the stem. The depth of the epidermal cells is more constant than their width or length, being about 20 to $3 \circ \mu$. Their outer wall is about $5 \mu$ in thickness. Treatment with concentrated sulphuric acid dissolves the rest of the cell and leaves the cuticle as shown on pl. I, fig. 5. Caustic potash causes the outer wall to swell slightly, when the striated cuticularized portion can be seen covered by the more refractive cuticle proper. Schultze's solution stains the epidermis orangerufous, the stain showing over the same portion of the cell wall that is left after the action of sulphuric acid. Hence we may conclude that the external and part of the lateral walls of the epidermal cells are cutinized.

\section{TRICHOMES \\ Pl. I, Fig. 2}

The Trichomes are simple hairs formed by the prolongation of one epidermal cell, and when young are filled with protoplasm. Concentrated sulphuric acid does not dissolve them, and Schultze's solution stains them the same color as the outer wall of the epidermal cells. Hence I conclude that their cell walls are cuticularized. Their average length is about .4 mm. They are divided by septæ into three or more cells. At the base of the hair the wall is equal in thickness to the outer one of the epidermal cells, but soon becomes much thinner, and the greater portion of the hair is bounded by a wall about $2 \frac{1}{2} \mu$ in thickness.

\section{Stomata}

Pl. II, Fig. $3^{a}$

These are most numerous on the youngest portions of the stem, and, with one exception, all I have seen have their opening parallel 
to the axis of the stem. It is difficult to estimate the number in a given space, as they are very irregularly distributed and the proportion varies with the age of the stem. In a square millimeter of epidermis I have counted ten stomata in one case and in others but one; perhaps five would be a fair average for the younger portions of the stem.

\section{PAPILL $A$}

These are developed on the older portions of the stem and appear to be formed by a thickening of the central portion of the outer wall of the cells of the epidermis.

\section{CORK}

As stated before, the outer wall of the epidermis is deeply cutinized, but in the younger portions of the stem we find no cork. As the stem increases in age and the lateral walls of the epidermal cells become suberized, the next cell, the cork cambium or phellogen, divides tangentially, the outer half forming the first cork cell which is suberized in the same manner as the epidermis. The inner half of the cell again divides, and in this way cork is continually formed. The development of the cork is shown on pl. II, fig: 4 , in which $p$ is the phellogen which divides to form the cork cells $c$. The alteration that takes place in the cell walls changing them from cellulose to cork proceeds from the outer wall to the inner one.

"It is not possible to account satisfactorily for these substances, subterin and lignin, in cell walls. They are probably the result of modification of the cell wall and not of interfiltration." 1 This statement is supported by the manner in which the phellogen cells of Hoya carnosa become suberized. Treatment with sulphuric acid shows this very plainly. In the younger portions of the stem the epidermis alone is left after the parenchyma is destroyed, then the lateral and finally the inner wall remains, the suberization always taking place toward the phellogen. Now it has been demonstrated that in conifers the cells become suberized after they have lost their protoplasmic contents, and this would seem to be the case in the cork of Hoya carnosa.

As soon as the cork is formed, the cells on the outside are shut off from further supply of nourishment, as far as we know, and if the 
suberization was the result of interfiltration, it would seem as if it should proceed from the growing portion of the plant, and not toward it from those that are dead. If the suberization was caused by the cell walls absorbing the contents of the cell, it is but fair to suppose that they would become suberized equally, although the opposite might be the case. However it may be, in Hoya carnosa it would seem as if some change which we call suberization took place in the cell wall, caused by being cut off from the supply of nourishment.

\section{The Outer Band of Parenchyma}

This is most prominent in the younger parts of the stem and is gradually reduced in thickness as the plant increases in age, till in the older portions it is equaled in depth by the cork. It is composed of spherical cells having thin cellulose walls, varying in diameter from to to $5 \circ \mu$ and increasing in size from the cork to the sclerotic girdle. The cell walls dissolve readily in sulphuric acid and are turned blue by the action of Schultze's solution. In the older portions of the stem they become irregularly thickened and then present a pitted appearance.

This band contains most of the chlorophyll and starch, also protoplasm, sclerotic cells, milk tissues, crystals of oxalate of lime, and the coloring matter of the younger portions of the stem. The last is a rose-purple, apparently homogeneous fluid. Alcohol dissolves it rather slowly but much faster than it does the chlorophyll. The addition of caustic potash changes the color to a sea-green, which is quite distinct from the yellowish green of the chlorophyll. The contents of all the cells of the bark are changed in color to an applegreen, which decreases in intensity toward the cambium and deepens in the vicinity of the cells that before contained the purple coloring matter. Hence it would appear that this material is contained in all the cells of the bark, but only in the outer ones does it become visible. The green color produced by potash gradually fades and leaves the chlorophyll granules apparently unaltered in color and form. Concentrated hydrochloric acid causes the color to change to a rich winepurple, which is confined to the cells containing the coloring matter and does not spread through the other cells like the green caused by potash. The color lasts perhaps ten minutes and then fades. Strong sulphuric acid has the same effect, but the walls of the parenchyma swell and are gradually destroyed. 
Schultze's solution at first changes the color to wine-purple and then shows the cells that contained it to be quite filled with starch. I have been unable to identify this substance with any description at my command of the coloring matter of plants. It is probably complex in structure, and further investigation is needed by some one more skilled in micro-chemistry than myself.

\section{Crystals}

These are composed of oxalate of lime and are contained in considerable numbers in this band of tissue, mostly outside of the sclerotic girdle. They are of a general spherical shape, presenting many sharp points over the surface as shown in pl. II, fig. 6 . It has been stated ${ }^{1}$ that they are inclosed in a cellulose wall and supported by threads of cellulose; this I have been unable to confirm, but think from the way in which they act when treated with hydrochloric acid or Schultze's solution that it is so. They certainly have a nucleus of organic matter.

\section{Mirk Celis}

Pl. I, Fig. 7

Davids, in 1872 , published a pamphlet containing the results of his investigations of the milk cells of the Euphorbiacece, Moracea, A pocynacee, and Asclepiadacee, and there gives references to the literature on the subject. The Apocynacee and Asclepiadacece he treats together, taking Nerium oleander as the type of one, and Hoya carnosa of the other, stating that in the latter the milk cells are almost exclusively confined to the parenchyma inside the sclerotic girdle. He gives their diameter from I8 to $2 \mathrm{I} \mu$, states that they are moderately branched, have no septa, and that their ends are closed. Also that they are formed in the growing point and are developed simultaneously in the bark and in the pith. They are not cell fusions but cells which by stretching and branching reach a considerable length in the intercellular space. They consist of fundamental cells and are not to be considered homologous with the true bast nor as part of the bundle systems (Gefassbündel Systeme). They do not anastomose with each other and therefore build no "system" in plants. As far as my investigation has gone the above observations are correct, but the milk cells are 
found outside of the sclerotic girdle more frequently than the above statement would seem to imply. They are filled with a greenish yellow fluid distinctly granular in structure. They can be very readily. seen in a longitudinal radial section and also in a tangential one that passes through the parenchyma of the bark.

\section{ChLOROPHyLI}

The chlorophyll is principally contained in the outer border of the parenchyma and is composed of granules about $5 \mu$ in diameter. I have been unable to decide whether they contain starch, but think that they do. The inner band of parenchyma also contains chlorophyll on its outer boundary, but it is not found in any other parts of the stem, to my knowledge.

\section{STARCH}

In the outer band of parenchyma starch is very abundant and completely fills some of the cells. The granules vary in size, but $5 \mu$ would perhaps be a fair average. They do not show any markings as far as I have been able to observe, except a slight suggestion of a granular structure. In this band of tissue starch also occurs in the inner ring of parenchyma, in the wood, pith, and medullary rays, if what I consider the latter proves to be correct. The occurrence of starch varies with the treatment the plant has received, for on making a section of a plant that had been for some time without water, the starch had almost entirely left the parts of stem where it was abundant before. In regard to the protoplasm I can only say that it is contained in the cells of this band, but I have not attempted to investigate its properties, as the object of this paper is to describe the structure of the plant cells rather than their contents.

\section{Sclerotic Cells}

These will be considered when treating the sclerotic girdle. It is only necessary to state here that they occur in abundance just under the bark and are irregularly scattered through the band of parenchyma. They increase in number as the plant grows older, and it is in the oldest portions of the stem that we find them most numerous.

This plant offers better opportunities for the study of these cells than any known to me. They are to be found in the petiole and leaf 
as well as in the stem, and being so abundant, their development can easily be traced, and the changes that take place in the contents of the cells that later become transformed offer an interesting field for investigation. It is difficult to account for their presence. The sclerotic girdle may be readily supposed to be for the purpose of strengthening the stem, but these separate cells cannot be considered in that light, as they are surrounded by parenchyma and simply add their weight to the stem without contributing to its support. They do not connect with each other except where two or more happen to be in contact, and therefore can hardly be considered as part of the system of the plant. They may better be regarded as the result of secretions for which the plant has no further use.

\section{SCLEROTIC GIRDLE}

The sclerotic girdle makes its first appearance in the third or fourth internode by the lignification of some of the cells of the parenchyma surrounding the bast, thus forming a broken ring. The intervening cells soon become lignified, and we have the girdle formed of a single row of cells which afterward increases to two or more rows.

Now if a young portion of the stem in which the sclerotic girdle has not yet formed is treated with iodine, the first row of cells surrounding the bast will be seen to be filled with starch forming a distinct and striking circle of a dark blue color. It is the row of cells surrounding those containing the starch that develop into the sclerotic girdle, and it seems almost impossible to resist the conclusion that the starch is in some way connected with the growth of the sclerotic cells.

\section{Lignification OF tHe Sclerotic Girdle}

The walls of the cells that form the girdle are at first slightly thickened on all sides, leaving small pores which later form canals as shown on pl. II, fig. 7. I have not been able to decide whether these "pores" are holes through the cells or spaces left unlignified, but I think the latter, as it seems that if they were holes they would appear before lignification, which, as far as my knowledge extends, is not the case. The cell walls then increase in thickness either by the formation of substance on the inside or interfiltration, between the pores, which thus become canals. In my opinion the cell walls are formed by layers added to the inside, as they are distinctly striated, 
and as the canals grow longer, their ends approach each other, the portions of the cell becoming wedge-shaped, as shown on pl. II, fig. 7, and this would be hard to account for on the theory of interfiltration, for then as the cell becomes more and more lignified, the inner portion would have to contract or the canals become closed. Now while some of the canals do run together and form one, the majority of them run from the circumference to the center. At last the cell becomes almost entirely closed, with the exception of the canals before mentioned.

An interesting problem arises in connection with the sclerotic girdle. It is formed in the young stem and incloses a portion of the soft tissues between itself and the wood. Now as the stem becomes thicker, the girdle must increase its diameter. The cells surrounding it keep pace with the enlargement of the stem by the simple act of division. The sclerotic cells do not divide, to my knowledge, for they are lignified almost to the center, and any division could be very easily seen. The problem is, how does it grow? We know that the tissues of plants are under considerable pressure, as is shown by simply cutting a stem in two, when the fluids contained will immediately exude, and this can be explained only by the supposition that they are squeezed out by the contraction of the tissues surrounding them. This tension will explain the flattened form assumed by the sclerotic girdle in the older parts of the stem, for, as stated above, the compression takes place on the radial line. The difference in shape between the cells composing the girdle and the sclerotic ones near it is very marked, the latter being comparatively round. The increase in tangential diameter the cells receive would seem hardly sufficient to allow the stem to expand as it does. The following experiment was made. A section was chosen in which the sclerotic girdle had partly formed and in which the cells composing it were almost round. The diameter of the girdle was measured and found to be $2 \mathrm{~mm}$; the circumference was then calculated and found to be $6.2832 \mathrm{~mm}$. The cells composing the girdle were counted and found to be about 209 in one case and 226 in another. The former figures give $.03 \mathrm{~mm}$., the latter .0288 mm., as the diameter of the cells composing the girdle. An average cell of the girdle was then measured tangentially and found to be $.035 \mathrm{~mm}$. in diameter. As the cells are slightly longer in that direction than radially, these figures are quite close, and we may adopt 
the figure obtained by calculation $(.03 \mathrm{~mm}$.) without serious error. Making the same calculation for a girdle $3 \mathrm{~mm}$. in diameter where the cells were 220 in number, we find their diameter to be $.04 \mathrm{~mm}$., while their measured diameter is $.05 \mathrm{~mm}$., the difference being doubtless due to the overlapping of the cells.

$$
\text { Calculation } \frac{2 \times 3 . \mathrm{I} 4 \mathrm{I} 6}{20.9}=\frac{6.2832}{209}=.035 \mathrm{~mm} \text {. }
$$

Hence we see that the elongation of the cell is sufficient to account for the increase of the girdle thus far. But when we look at a section in which the sclerotic ring measures 7 or $8 \mathrm{~mm}$. in diameter, we see that it contains many small round cells as well as the flattened ones, and in some places the girdle is separated by a cell of parenchyma, thus suggesting that the increase in growth is not due to the compression of the cells alone, but that some of them separate, and the spaces left vacant are filled by parenchyma that soon becomes lignified. This must take place very rapidly, as I have never found sclerotic cells in the process of formation in the girdle of the older portions of the stem.

As stated before, the object of the sclerotic girdle is probably the support of the young stem, as the plant twines but feebly. When the stem reaches a diameter of ten or twelve millimeters, the girdle no longer stands out as a conspicuous component of the section, but is separated in places and appears to be gradually losing its identity, and I venture to say, if its object is as I have supposed, that in a still larger stem the girdle, being no longer needed for support, would be found disintegrated and mingled with the sclerotic cells of the parenchyma.

\section{The Inner Band of Parenchyma}

This is composed of cells similar in structure, shape, and size to those of the outer band, and also contains besides the bast fibers, sclerotic cells, chlorophyll, crystals, and starch. It is the outer cells of this band that are filled with starch before the development of the sclerotic girdle. The bast fibers lie scattered in bundles mostly near the outer boundary of the band. They are fusiform in shape, about $20 \mu$ in diameter, their walls are about $6 \mu$ in thickness, and are very faintly marked in the manner shown on pl. II, fig. 8.

It is very difficult to determine their average length. None of those I have been able to isolate with certainty have measured over 
$3 \frac{1}{2} \mathrm{~mm}$. The ends of the fibers are generally prolonged into slender threads, but in some cases the termination is quite abrupt, and they expand slightly near the end as shown on pl. II, fig. $8 b$. Sulphuric acid causes the fibers to swell, and contract violently in the direction of their length, and finally dissolves them. Schultze's solution changes them to a deep azure-blue color; while iodine shows a slight yellow tinge. They contain a fluid that stains readily with magenta and iodine, and does not appear to be affected by sulphuric acid. Scattered here and there in this band of parenchyma will be seen crystals, sclerotic cells, and milk cells (latex cells). These are in all respects similar to those found in the outer band, and a detailed description of them need not be repeated.

\section{CAMBiUm}

The cambium cells are composed of exceeding delicate cellulose walls and by successive division form the wood, medullary rays, etc., on one side, and the tissues that surround them, on the other. The development of these tissues has not been attempted. The cells are generally about I $_{5} \mu$ in cross section and $5^{\circ} \mu$ in length.

\section{WOOD}

Fritz Müller, in an interesting paper in the Botanische Zeitung, February, I866, describes the structure of the wood in climbing plants about Disterro and gives figures showing the irregular form that it sometimes assumes. He states that these irregularities are due to the separation of the woody portions or to "strings of soft tissue drawn through them," the stem becoming thereby more flexible " " than if the mass of wood was regularly formed.

In the young stem of Hoya carnosa the outer boundary of the wood is quite regular and passes in to the cambium in the ordinary manner. But as the stem increases in age, the growth is more and more irregular, till in a stem about Io $\mathrm{mm}$. in diameter the appearance of a section is like that shown on pl. II, fig. I, 4; the wood being generally much thicker on one side than on the other and penetrated in many places by wedge-shaped masses of parenchyma. I have not been able to decide whether the wood separates and allows the soft tissue to penetrate it, or whether it simply grows irregularly around them, but I think the former, as in the young portions of the stem the wood makes 
an unbroken circle, while in some of the older portions the parenchyma has reached almost to the pith and the distance separating them is much thinner than the band of wood in the young stem.

In a tangential section the masses of parenchyma are shown to be lenticular in shape with their longest axis parallel to the axis of the stem, looking very much like medullary rays, which I at first took them to be, as none of the other cells in such a section show the ordinary appearance so generally characteristic of these tissues. If, however, we make a radial section, we can distinguish four well-marked forms of cells: (I) the wood cells proper; (2) the ducts; (3) the cells of the parenchyma, if the section has been made through a portion of the stem containing them; (4) rectangular cells, very regular in form and length, their ends thus forming well-marked lines across the section. These, I think, are the medullary rays.

Next to the pith will be seen cells with thickened walls giving them the appearance of a spiral. These latter are best seen in a section of a young stem. These various tissues with the exception of the parenchyma all exhibit the characteristic reactions of lignified cells, staining with the various reagents used for the purpose of identifying them, such as phlorglucin and thymol. As far as my investigation has gone, the ducts contain only air. The medullary rays and parenchyma are usually filled with starch; the wood cells sometimes contain the latter, but are generally empty. The position of the starch varies with the season of the year and the circumstances under which the plant has been kept.

\section{Ducts}

In a transverse section of the stem these will be noticed scattered through the wood. Their diameter is much greater than that of the wood cells, being from 25 to $5^{\circ} \mu$, while the latter are quite constant in size, having a cross section of about I $5_{5} \mu$. The length of the ducts varies greatly, some being Ioo $\mu$ long and others only Io $\mu$. They form large canals through the stems, the ends meeting sometimes at right angles, but generally overlap, making an angle of about $40^{\circ}$ with the direction of their length. Their walls are about equal in thickness to the walls of the wood cells, but are regularly pitted as shown on pl. II, fig. 3 .

Sachs, in his "Physiology of Plants," states that Theodore Hartig, 
twenty or thirty years ago, showed that the "histological elements of the wood are not in open communication with each other and that the bordered pits of the wood cells (and the vessels of foliage trees) are not actually perforated, but closed by fine membranes." This is confirmed by Sachs, in the experiment he gives on the same page, namely, by filtering through the wood of a conifer a fine emulsion of cinnabar, the cinnabar not penetrating the wood cells. $\mathrm{He}$ states that this is also true of foliage trees. In some thin sections of wood I thought I could see the connection between the cells, but could never satisfy myself that there really was one, as it is very difficult, and in fact a matter of chance, to get a section showing clearly the edge of the wall of a duct.

The ducts are surrounded by small wood cells and are generally in groups, sometimes two being contiguous and presenting the appearance of one large one having a longitudinal partition. At the point where the ends of two ducts meet, the walls are not pitted around a circle indicating the point of union, but in the central portion of the transverse wall is a circular plate that can be removed, as some sections show a space that was formerly occupied by the disk, and in a slide of macerated wood cells we find these round perforated portions of the ducts abundant. On pl. II, fig. 3 , is figured the end of a duct, showing the circular space mentioned, and fig. $3^{a}$ of the same plate shows the disk that formerly occupied it.

The ducts are formed in the cambium, and while increasing in thickness, their walls become pitted. These pits are present in both the tangential and radial faces and also where the ducts meet end to end. Some portions of the walls, however, are without pits, but their relation to the position of the cell I have not determined, as I have only noticed the fact with certainty in longitudinal sections, and, of course, it is not possible to say what occupied the place before it had been cut off.

\section{Wood Cells}

These are very irregular in shape, and some of the forms they assume are shown on $\mathrm{pl}$. II, figs. $5^{-5}$. Their diameter is quite constant, being about I $_{5} \mu$. Their length varies, as a glance at the plate mentioned above will show ; some are $5 \mathrm{~mm}$. in length and others but .I $5 \mathrm{~mm}$. They may easily be obtained for examination by macerating a portion of the wood, or by boiling a piece in Schultze's solution. 
They have rather thick lignified walls that are marked by pits having a slit-like appearance, the longer axis of the slit forming an angle with the sides of the cells.

\section{Medullary Rays}

The cells of the medullary rays in the plant we are considering present an exception to those usually found, in that they stand vertically, or with their greatest length parallel to the axis of the stem. Generally these tissues are well marked in a tangential section by their lenticular form and the difference in the thickness and composition of the walls of their cells as compared with those of the other components of the wood; they show equally well in a radial section the fact that their greatest length is along the radial line, thus crossing the axis of the other cells at right angles.

In Hoya, as stated before, tangential sections of the old parts of the stem show lenticular masses of parenchyma that might be easily mistaken for medullary rays. The young stem, however, does not contain them, and if we admit they are the rays, we must concede that none exist in the younger portions of the plant. If a radial section of a stem is examined, cells will be noticed that are quite regular in shape, as shown on pl. I, fig. 6, being prismatic in form, and, as shown in the section, rectangular in outline and usually quite filled with starch. Their sides are pitted, as are also the ends. They are generally about I $\mathrm{mm}$. in length, though sometimes longer or shorter, and about .0. $5 \mathrm{~mm}$. in diameter. In a cross-sèction of the stem they may be easily recognized by the starch they contain and by the pitted plate or end of the cells, some of which are generally shown. "But few minute investigations on the structure of the cells of medullary rays exist, and many details of structure are still to be discovered." 1

If I am correct in supposing the tissues described above as medullary rays, they resemble the wood cells very closely in all but their shape. They run from pith to bark and are marked with pits similar to those of the wood cells. The inner boundary of the wood is formed by a few long cells with the walls thickened in a spiral or annular manner. In cutting a section the cells separate very readily and, as it were, uncoil. They are lignified like the wood, but in cross-section are circular with the walls slightly thinner.

${ }^{1}$ De Bary, "Comparative Anatomy of Ferns and Phanerogams," p. 486. 

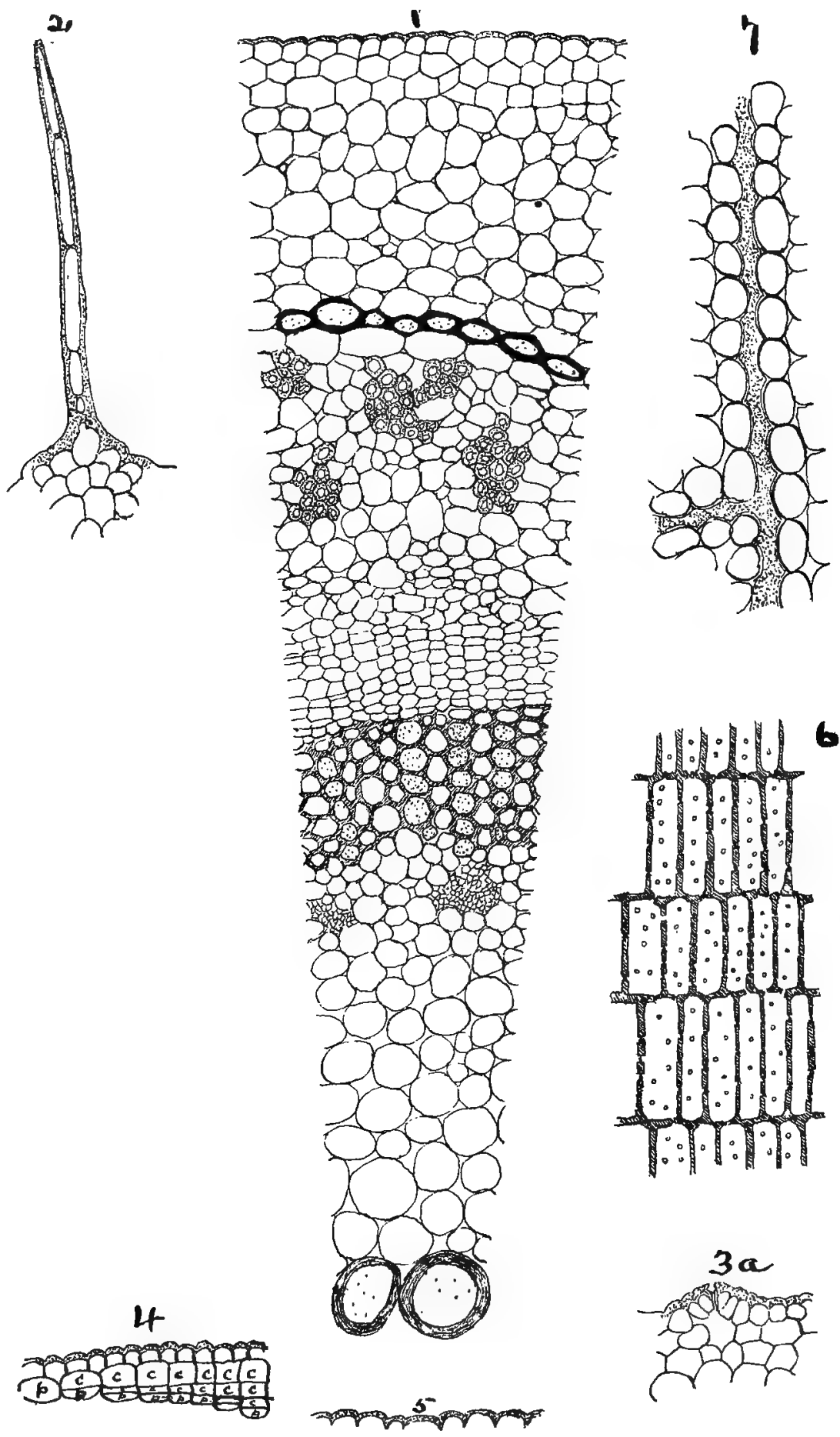
monstis

1. 1.1.

$\therefore \circ \cdot 10$

$\circ .10 \%$

$\therefore$ N $\circ$

a

.

$\circ$.

$\ldots$. 0.1.

. $\therefore 0^{\circ}$

$20 \mathrm{C}$

- 0 .

1 0.10

$.201 \cdot 1 \cdot 1$

‥ $\circ \circ$

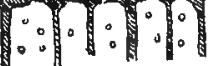

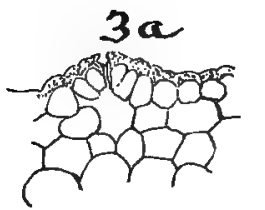

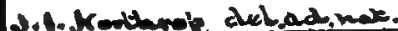




\section{PITH}

The pith is composed of spherical cells from to to $5 \circ \mu$ in diameter, being generally filled with starch and having thin cellulose walls without markings, as far as I have been able to observe. In the center are a number of sclerotic cells similar to those found in other parts of the plant, but more regular in shape. These form the axis of the plant, growing upward in advance of the sclerotic girdle. They are of the same size as the cells of the pith and are developed like those of the girdle by the thickening of the cell wall. Crystals also occur in abundance, and are sometimes surrounded by the sclerotic cells. They have a nucleus of organic matter and often completely fill the cell that holds them. Around the pith will be noticed clusters of small cells presenting the appearance shown on pl. II, figs. I, 4 . These, I think, are what Davids calls Weichbastbündels. They are about Io $\mu$ in diameter and $5 \circ \mu$ in length. These cells are filled with a colorless fluid and bounded by thin cellulose walls. They are sometimes arranged around the pith, forming four well-marked patches, as shown in the figure referred to.

Such is a general account of the structure of Hoya carnosa. If we glance for a moment at its methods of growth, we at first see the young stem with the column of sclerotic cells in the center, which, as it advances, is followed by the girdle which envelops the tissues within it and furnishes a rigid support to the plant with the least expense of material, and, if my supposition prove correct, disappearing when the wood has reached a sufficient thickness to render its presence superfluous.

I wish in conclusion to acknowledge my obligations to Dr. N. L. Britton and others who have kindly assisted me with advice and suggestions.

\section{EXPLANATION OF PLATES}

\section{Plate I}

Fig. I. Cross-section of young stem showing the different zones of tissues mentioned on page 4 .

Fig. 2. Hair from young stem. Page 7 .

Fig. 3a. Transverse section of a stoma. Fig. 4. Diagrammatic showing development of cork. $p=$ phellogen. $c=$ cork. Page 8 .

Fig. 5. Epidermis of stem as left after action of sulphuric acid. 


\section{HISTOLOGY OF STEM OF THE WAX PLANT}

Fig. 6. Medullary ray. Longitudinal radial section. Page zo.

Fig. 7. Milk cell from outer band of parenchyma.

All figures magnified 200 times linear.

\section{Plate II}

Figs. I and 4. Cross-section of stem showing irregular growth of wood. I $X$ Io times linear; $4 \times 40$ times linear, p. 24 .

Fig. 2. Tangential section of old stem showing lenticular form of penetrating parenchyma. $\times$ ro times linear.

Fig. 3. Short duct from old stem showing manner of pitting. $3 a$, disk that occupies space above it. $\times 400$ linear, p. 27.

Figs. 5-5d. Different forms of wood cells. $\times 200$ linear, p. 29.

Fig. 6. Crystal from pith of young stem. $\times 200$ linear, P. II.

Fig. 7. Sclerotic cells from girdle of stem. $\times 200$ linear.

Figs. 8-8b. Bast fibers showing manner of striation. $\quad \times 200$ linear. 
2
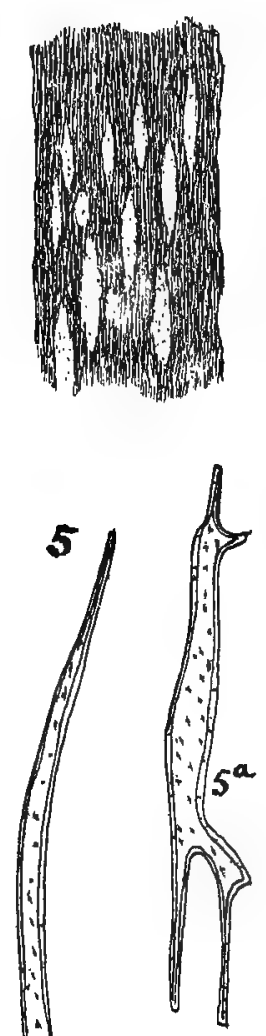
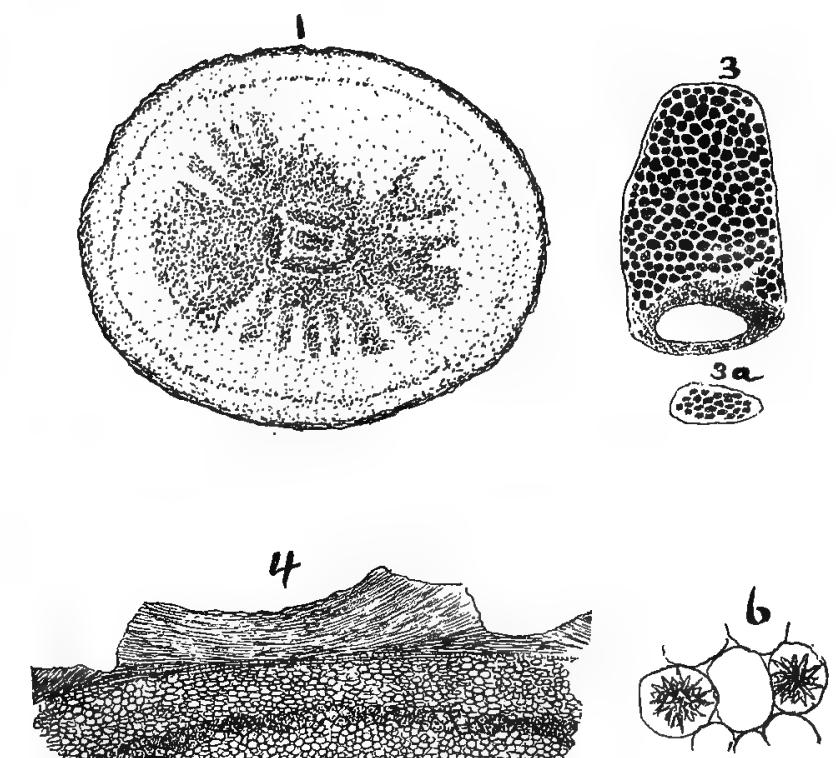

$5^{5^{-6}}$
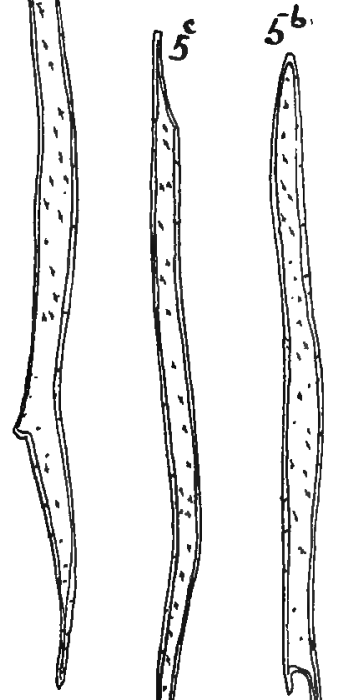
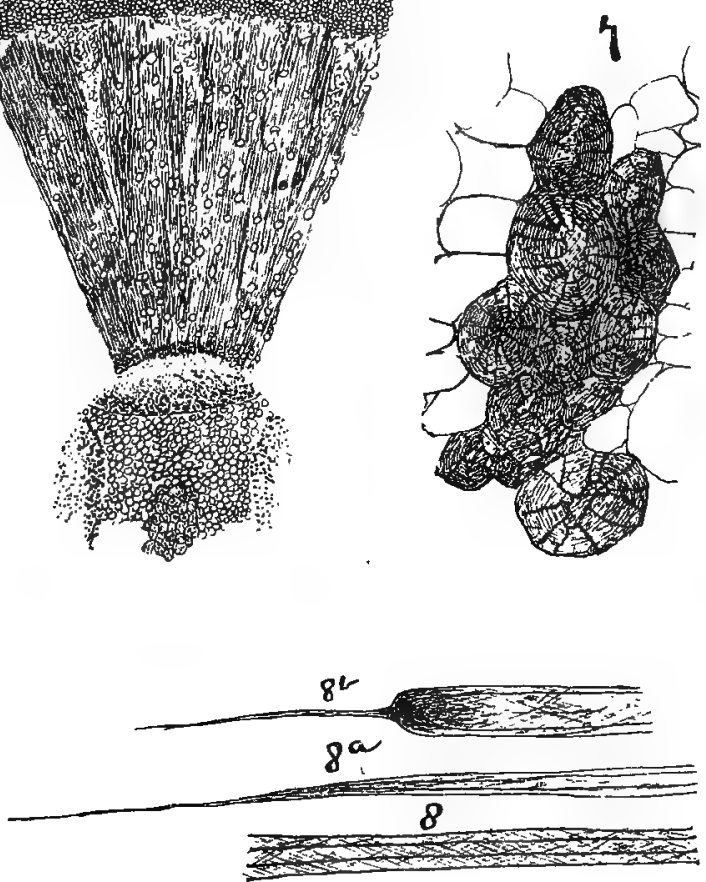

1. Warturat deladanal. 



\section{INDEX TO BAHAMAN PAPERS}

The genera of Actinia, Birds, and Crustaceans are given in the following index, and the families of plants, together with all the new species.

Acanthacæa, 183

Acanthonyx, 79 .

Acasta, 96.

Achelous, 76, 77 .

Actæa, 75 .

Actinia, 103-117.

Actites, 6I.

Agialitis, 6r.

Agelaius, 56.

Aiptasia, I03, II 7 .

Aizoacex, I53.

Aletris bracteata n. sp., I44, Plate I.

Alpheus, 89-93.

Alpheus hippothoë bahamensis n. var, 89, Fig.

Alpheus nigro-spinatus n. sp., 9 , Fig.

Amarantaceæ, 152 .

Amaryllidacea, 145.

Anacardiaceæ, I64.

Anastraphia northropiana n. sp., Igo.

Andros, general account, I3, 23, 24, 28, 29, 50, I22.

Previous collectors, 50, 5I, I20, I 26, I 27.

Anguria keithii n. sp., I87, Plate 18.

Anonacex, I53.

Anous, 64 .

Antrostomus, 58.

Apocynacex, I75.

Ardea, 62, 63.

Arecacex, I4I.

Aristolochiaceæ, I 50 .

Asclepiadacex, I75.

Athanas ortmanni n. sp., 93, 94, Fig.

Bahaman collection, general summary, 25,34 .

Bahama Islands, general description, 27, 28.

- Formation, 46, 47 .

Bahaman trip, general account, I-24.

Balanoglossus, 5 .

Batideæ; I52.

Bignoniacex, 182 .

Birds, general notes, 48 .

- Annotated list, 50-65.

Bixaceæ, I 68.

Blacicus, 57 .

Boraginaceæ, 178.

Bromeliacex, I44.

Burseraceæ, I62.
Cactaceæ, I7I.

Cæsalpinaceæ, $I_{5} 6$.

Callichelidon, 55 .

Callinectes, 76 .

Canellaceæ, 160 .

Capparidaceæ, $\mathbf{I} 54$.

Cardisoma, 72.

Caricaceæ, I 70.

Cassia Caribaa n. sp., I56, Plate 6.

Catesbra fasciculata n. sp., I84, Plate 16.

Cathartes, 6r.

Caulerpacer, $\mathbf{1} 29$.

Celastracex, I64.

Ceramiacex, $\mathbf{r}_{3} \mathrm{r}$.

Ceryle, 60.

Chætangiaceæ, IзI.

Characeæ, I32.

Chara depauperata n. sp., I32.

Charadrius, 6r.

Chenopodiaceæ, 75.

Chlorodius, 75 .

Chordeiles, 58.

Cladophoraceæ, 129.

Coccyzus, 60.

Codiaceæ, I29.

Cœnobita, 8I.

Coereba, 55 .

Columba, 6r.

Columbigallinas, $6 \mathrm{I}$.

Combretacex, I7I.

Commelinacex, I44.

Compositæ, I88-Igo.

Compsothlypis, 53 .

Condylactis, I03.

Coniferæ, I34.

Convolvulacere, I76, I77.

Corallinaceæ, I3I.

Crassulaceæ, I54.

Crossopetalum coriaceum n. sp., I65, Plate g.

Crotophaga, 59.

Cruciferæ, 154 .

Crustacea, report on, 69-98.

Cucurbitaceæ, I87.

Cultivation of sisal in the Bahamas, 212224.

Cuscutaceæ, I77.

Cycadaceæ, I34.

Cyclospathe n. gen., I4. 
Cyclospathe northropi n. sp., I42, I 43 .

Cyperaceæ, I3 $_{6}$.

Dasycladacea, $\mathbf{1 3 0}$.

Dendrocygna, 64.

Dendroica, 53.

Dictyotacer, $\mathbf{1 3 0}$.

Dioscoreacea, 146.

Diplactis, t05, ro8, ro9, III, Fig.

Discosma, IO4.

Domœeia, 74 .

Doricha, 58.

Dromidia, 79.

Dryobates, 60.

Ebenaceæ, I74.

Eriphia, 73.

Erythroxylon reticulatum \&. sp., I59, Plate 8.

Eupatorium bahamense n. sp., r88, Plate Iq.

Euphorbiacea, 162-164.

Eutheia, 56.

Falco, 60.

Ferns, I33, I34.

Flora of New Providence and Andros, II ${ }^{-}$ 2 II.

- Analysis of collection, $127-\mathrm{I} 28$.

Botanical regions, I23-126, 2 II.

Endemic species, 207.

Notes on distribution, 207, 2 I I.

Relations of flora, I90-I93.

Tables showing distribution, I 94-207.

Fregata, 64 .

Fucaceæ, I30.

Fungi, list, 132 .

Galeoscoptes, 52 .

Gecarcinus, 7 7 , 72

Gemmaria, ro4.

Gentianaceæ, 175 .

Geology of Bahamas, 29-47.

Banana-holes, $17,36,38$.

- Boiling holes, 35,36 .

Caves, 8, 33, 34 .

Erosion, 31, 32.

Effects of vegetation on surface rhizomorphs, $38,4 \mathrm{r}$.

Reefs, 13, 44 .

Subsidence or elevation, $42-45$.

Surface deposits, 3 r.

Geothlypis, 54.

Goniopsis, 73.

Gonodactylus, 95 .

Goodeniaceæ, I88.

Graminex, I35.

Grapsus, 73.

Hamatopus, 6r.

Helicteres spiralis n. sp., $167, \mathbf{1 6 8}$, Plate.

Heliotropium nanum n. sp., I 78 , Plate.

Helminthocladiace $æ$, I 3 I.
Heteractæa, 75 .

Heteractis lucida, I03-ro7, I I 7, Fig.

Himantopus, $6 \mathrm{I}$.

Hydrophyllaceæ, I77.

Hymenocallis arencola 1 .. sp., I46, Plate 2. Hypericacex, I68.

Icturus northropi n. sp., 56, 66-68. Colored plate.

Ilicacex, $\mathrm{x} 65$.

Isaurus, IO4, II2-II5, Fig.

Jacquinia pq $173 \mathrm{~m}$. plp!
Labiate, I80.

Land crabs, 8 , I8.

Larus, 64.

Lauraceæ, I $_{53}$, 154 .

Leander northropi n. sp., 87, 88, Fig.

Lebrunea, I04, I08.

Leiolephus, 72.

Lentibulariacex, 182 .

Lichens, list, I32.

Liliaceæ, I 44 .

Linaceæ, I59.

Linum bahamense n. sp., I59, Plate 7 .

Lithotrya, 95 .

Loganiacere, 174 .

Lophactæa, 75 .

Loranthaceæ, 150.

Loxigilla, 6, 56 .

Lythraceæ, 170.

Macrocoloma, 77 .

Malpighiacex, I60.

Malvaceæ, I67.

Mammals, 24, 48 .

Map New Providence and Andros, 27.

Marine algæ, I29-I3I.

Melastomacer, 72 .

Metastelma barbatum n. sp., I75, I76, Plate I4.

Microphys, 77.

Mimocichla, 52.

Mimosacez, I54, I55.

Mimus, 52.

Mithrax, 78, 79.

Mniotilta, 53.

Moringacea, 164 .

Mosses, list of, 133 .

Myiarchis, 57.

Myrsinacea, I73.

Myrstiphyllum ligustrifolium n. sp., I86,

Plate I7.

Myrtaceæ, I 70 .

Naiadacex, I35.

Nassau and environs, general description, I-4.

New Providence, general description, 27, I I 9 , I 20.

Nyctaginaceæ, $\mathbf{5} \mathbf{2}$.

Nycticorax, 63 . 
Ocypodea, ,

Oleacex, I74.

Onagraceæx, I 72.

Orchidaceæ, I46-I 49 .

Othonia, 78 .

Oxalidaceæ, I 58.

Pachycheles, 80, 8I.

Pachygrapsus, 73 .

Palæmon, 87.

Palms, I36-I 44.

Palythoa, ro4.

Panopeus, 74 .

Panulirus, 83 .

Papaveracex, 154.

Papilionaceæ, 157.

Passifloraceæ, 169.

Paurotis n. gen., I38.

Paurotis androa, n. sp., I39, I40.

Pelecanus, 64.

Penæus, 94.

Petrochirus, 82.

Petrolisthes, 8r.

Phalacrocorax, 64 .

Phœnicopterus, I2, 63, 64 .

Phoradendron northropix is. sp., I5O, Plate 4.

Phymanthus, ro4. Phygel
Phytolaccaceæ, 152.

Piranga, 56.

Pitangus, 57.

Pithecolobium bahamense n. sp., 155 , Plate 5.

Plagusia, 72 .

Plumbaginacex, $x 73$.

Polioptila, 53.

Polygalaceæ, I62.

Polygonacee, I5I.

Polypodiaceæ, I33-ז34.

Porcellana, 8o.

Portulacaceæ, I53.

Primulaceæ, I73.

Pseudosquilla, 94.

Psilotaceæ, I34.

Rallus, 62.

Ranunculaceæ, I53.

Reptiles, 25.

Reynosia northropiana n. sp., I66, Plate Io.

Rhamnaceæ, $\mathrm{x} 66$.

Rhizophoracex, $x 70$.

Rhodactis, I04.

Rhodomelacex, I4I.

Ricordea, I04, I Io.

Riosaceæ, I 5.4.

Rubiaceæ, I 84,185 .

Rutaceæ, I6I.

Sabalaceæ, 537.

Samydaceæ, 172 .

Sapindaceæ, 165 .
Sapotaceæ, 173.

Saurothera, 59 .

Schizæaceæ, I33.

Scrophulariacex, I8r.

Seiurus, 53.

Sesarma, 72.

Setophaga, 54 .

Shells, list of, $99-$ IO2.

- Gastropoda, marine, roo-I02.

- Gastropoda, terrestrial, roo.

- Pelecypoda, 99.

Simarubeæ, 16r.

Smilacaceæ, I45.

Solanaceæ, I8I.

Speotyto, 60.

Sphyrapicus, 60.

Spindalis, 6, 55 .

Sporadinus, 59.

Starfishes, list of, 26.

Sterna, 64, 65 .

Stenopus hispidus, 83,84 , Fig.

Stenopus scutellatus n. sp., 85,86 , Fig.

Sterculiaceæ, I67.

Strix, 6o.

Symphemia, 6r.

Tecoma bahamensis ı. sp., I8z, I83, Plate I5.

Terminalia spinosa n. sp., I 7 r, Plate I 3.

Thrinax bahamensis n. sp., I37, I38.

Tiliaceæ, 167 .

Tozeuma, 88.

Turneraceæ, 169 .

Typhacea, 135 .

Tyrannus, 57 .

Uca, 70, $7 \mathrm{I}$.

Umbelliferæ, I73.

Valoniaceæ, I30.

Vanilla articulata n. sp., I48, Plate 3.

Verbenaceæ, I79.

Vireo, 55 .

Vitacex, I 66.

Xylosma ilicifolia n. sp., I68, I69, Plate I2.

Zenaida, 6r.

Zoanthus, ro4, I10-I I 2, Fig.

\section{MISCELLANEOUS PAPERS}

Eruption of Krakatoa, 225-239.

Plant Notes from Temiscouata County, Canada, I, 240-249.

Plant Notes from Temiscouata County, Canada, II, 250-254.

Plant Distribution of Mt. Washington, N. H., 255-258:

Study of Histology of Stem of Hoya carnosa, 259-277. 








3.
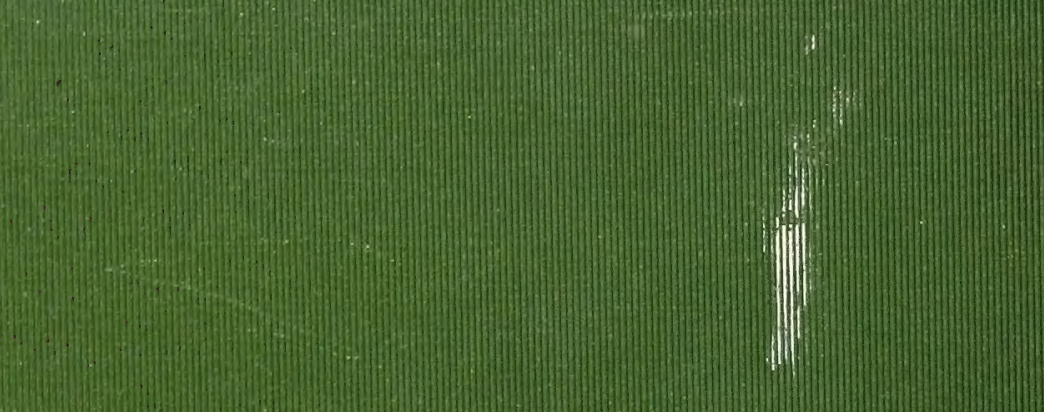

(1)

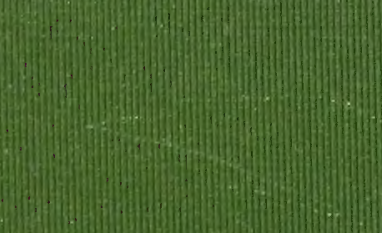

(1)

4. 1. (2)

(1) 